UNIVERSIDADE DE SÃO PAULO

INSTITUTO DE GEOCIENNCIAS

\title{
A SEQÜÊNCIA PERMO-PENSILVANIANA DA BACIA DO PARNAÍBA
}

\author{
Francisco Pinheiro Lima Filho \\ Orientador: Prof. Dr. Antonio Carlos Rocha Campos
}

TESE DE DOUTORAMENTO

Programa de Pós-Graduação em Geologia Sedimentar 


\title{
A SEQÜÊNCIA PERMO-PENSILVANIANA DA BACIA DO PARNAÍBA
}

\author{
FRANCISCO PINHEIRO LIMA FILHO
}

Orientador: Prof. Dr. Antonio Carlos Rocha Campos

\author{
TESE DE DOUTORAMENTO
}

COMISSÃO JULGADORA

Nome

Presidente: Prof. Dr. Antonio Carlos Rocha Campos

Examinadores: Prof. Dr. Edson José Milani

Prof. Dr. Joel Carneiro de Castro

Prof. Dr. José Roberto Canuto

Prof. Dr. Narendra Srivastava

SÃO PAULO

1999

\section{Assinatura}

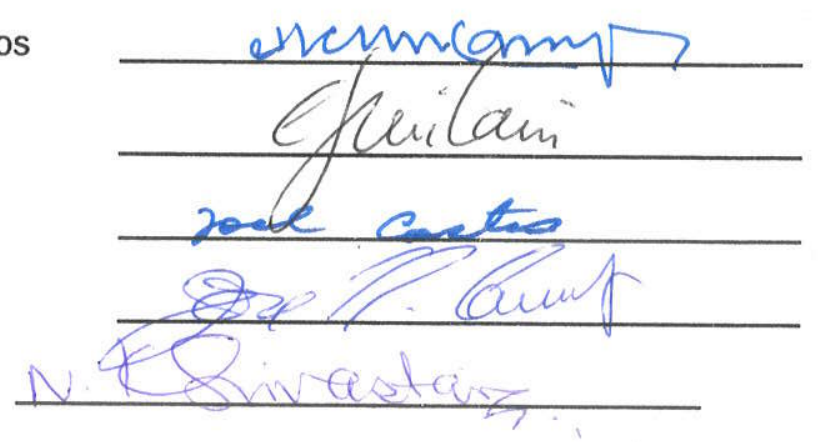


UNIVERSIDADE DE SÃO PAULO

INSTITUTO DE GEOCIENCIAS

DEDALUS - Acervo - IGC

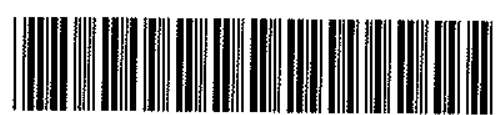

30900005104

AS SEQÜENCIAS PERMO-PENSILVANIANAS DA BACIA DO PARNAÍBA

FRANCISCO PINHEIRO LIMA FILHO

Orientador: Prof. Dr. Antonio Carlos Rocha Campos

TESE DE DOUTORADO

T2689

Programa de Pós-Graduação em Geologia Sedimentar

SÃO PAULO 


\section{ÍNDICE}

RESUMO i

ABSTRACT

AGRADECIMENTOS iii

1- INTRODUÇÃO

2- OBJETIVOS E METODOLOGIA 2

2.1-Objetivos 2

2.2- Metodologia 2

3- LITOESTRATIGRAFIA E AMBIENTES DEPOSICIONAIS DOS GRUPOS SERRA GRANDE E CANINDÉ

3.1- Introdução

3.2- Grupo Serra Grande 10

3.3- Grupo Canindé 12

4- EVOLUÇÃO DOS CONHECIMENTOS E NOVAS INFORMAÇÕES

LITOESTRATIGRÁFICAS E DOS AMBIENTES DEPOSICIONAIS

DA SEQÜÊNCIA PERMO-PENSILVANIANA DA BACIA DO

$\begin{array}{ll}\text { PARNAÍBA } & 15\end{array}$

4.1- Formação Piauí 15

4.2- Formação Pedra de Fogo 36

4.3- Formação Motuca $\quad 40$

4.4- Seções Estratigráficas $\quad 43$

5- SISTEMAS DEPOSICIONAIS $\quad 50$

5.1- Sistemas Deposicionais do Perfil da Baixa Fria 50

6- ESTRATIGRAFIA DE SEQÜÊNCIAS

6.1- Introdução 61

6.2- A hierarquia das Unidades Estratais 65

6.3- Unidades Estratais 65

6.4- Parasseqüências $\quad 67$

$\begin{array}{ll}\text { 6.5- Limite de Parasseqüências } & 70\end{array}$

6.6- Interpretação dos Mecanismos de Deposição 72 
6.7- Conjunto de Parasseqüências 73

6.8- Seqüências 75

6.9- Trato de Sistema de Mar Alto (TSMA) 78

6.10- Trato de Sistema de Mar Baixo (TSMB) 80

6.11- Trato de Sistema Transgressivo (TST) 82

7- ESTRATIGRAFIA DE SEQÜÊNCIAS EM BACIAS

INTRACRATÔNICAS

7.1- As Seqüências do Permo-Pensilvaniano da Bacia do Parnaíba 86

8. ESTRATIGRAFIA DE SEQÜÊNCIAS EM BACIAS

$\begin{array}{ll}\text { EVAPORÍTICAS/CARBONÁTICAS } & 104\end{array}$

$\begin{array}{ll}8.1 \text { - Introdução } & 104\end{array}$

8.2- Sistemas Carbonáticos 105

8.3- Sistemas Evaporíticos 111

9- MODELO DEPOSICIONAL DA SEQÜÊNCIA

PERMO-PENSILVANIANA NO INTERIOR DA BACIA. 117

10- CICLICIDADE NA SEQÜÊNCIA PERMO-PENSILVANIANA 125

$\begin{array}{ll}\text { 10.1- Introdução } & 125\end{array}$

10.2- O Gráfico de Fischer $\quad 129$

10.3- As seqüências Permo-Pensilvanianas de $4^{\mathrm{a}}$ ordem 133

10.4- Comparação entre as seqüências encontradas e

$\begin{array}{ll}\text { outras de mesma idade com periodicidade conhecida } & 137\end{array}$

11- CONCLUSÕES 141

$\begin{array}{ll}\text { 12- ESTAMPAS } & 142\end{array}$

13- REFERÊNCIAS BIBLIOGRÁFICAS 149 


\section{RESUMO}

A seqüência Permo-Pensilvaniana da Bacia do Parnaíba foi estudada em afloramentos, perfis radioativos e testemunhos de sondagens, para elaboração de um arcabouço crono-estratigráfico. A etapa inicial do trabalho consistiu de uma revisão bibliográfica sobre a litoestratigrafia e os ambientes deposicionais do Paleozóico da Bacia do Parnaíba, enfatizandose as rochas depositadas no Pensilvaniano e Permiano, bem como de uma revisão conceitual sobre a Estratigrafia de Sequêencias e bacias evaporíticas, abordando-se a aplicação desses conceitos aos vários modelos de bacias evaporítica, especialmente aqueles relacionadas ao contexto intracratônico. $\mathrm{Na}$ segunda etapa do trabalho foram descritos afloramentos e testemunhos de sondagens, e identificados padrões de empilhamento em perfis radioativos, todos utilizados na elaboração de seções colunares. A partir das seções levantadas foi possível identificar superfícies-chaves, associações litofaciológicas e tratos de sistemas. A distribuição das unidades aloestratigráficas e litoestratigráficas foi ilustrada em seções estratigráficas. Foram proposta modificações nos limites das Formações Pedra de Fogo e Motuca. Na terceira etapa foram analisados dados e discutidos os resultados. Os trabalhos foram desenvolvidos segundo duas abordagens: uma para a borda leste, essencialmente siliciclástica e outra referente a porção interior da bacia, num contexto evaporítico. Na borda leste foram utilizadas seções colunares de afloramentos e dados de subsuperfícies para elaboração de uma seção estratigráfica ao longo de mais de $260 \mathrm{~km}$, envolvendo essencialmente siliciclásticos com idade de deposição restrita ao Pensilvaniano. Foram então identificadas cinco seqüências de $3^{a}$ ordem e seus respectivos tratos de sistemas. Foi também sugerida a presença de prováveis vales incisos entre a seção colunar da Serra da Cruz e a localidade do poço 9. A outra abordagem, restrita a avaliação de dados de subsuperfície, permitiu a proposta de um modelo alternativo de bacia evaporítica para a Seqüência Permo-Pensilvaniana da Bacia do Parnaíba. A partir da identificação de superfícies chaves e do uso do Gráfico de Fischer, foram elaboradas duas seções estratigráficas que, a grosso modo, correspondem ao Pensilvaniano e ao Permiano. Na seqüência Pensilvaniana $\left(2^{\mathrm{a}}\right.$ ordem) foram identificadas seis seqüências de $3^{\mathrm{a}}$ ordem, com pelo menos duas delas correspondendo a seqüências compostas. Na porção mais central da bacia elas ocorrem com maior espessura e aparentemente sem hiatos significativos. Em direção as bordas da bacia, as espessuras das seqüências tendem a diminuir. Para os estratos permianos também foram identificadas seis seqüências de $3^{a}$ ordem. Estas seqüências apresentam pouca variação de espessura e geometria tabular. 


\section{ABSTRACT}

The Permian-Pennsylvanian sequence of the Parnaiba Basin was investigated through outcrops, gamma-ray profiles and core sampling, in order to establish its chronostratigraphic framework based on Sequence Stratigraphy concepts. The initial part of the study involved a bibliographical reappraisal of the Paleozoic depositional environments of the Parnaíba Basin, emphasizing the Permian-Pennsylvanian sequence. This was followed by a conceptual review on Sequence Stratigraphy and evaporite basins, with application of these principles to intracratonic basins. The lithostratigraphy of the Piauí, Pedra de Fogo and Motuca formations were re-evaluated and some modifications were proposed for the boundaries of the latter ones. Description of outcrops and drill cores, together with the identification of cyclic stacking patterns in gamma-ray profiles, were employed to work out columnar sections in the second part of the research. Based upon these sections, it was possible to identify key-surfaces, lithofaciological associations and system tracts. The distribution of the allostratigraphic and lithostratigraphic units was depicted in stratigraphic sections. The third part of the work involved data analysis and discussion of the results. In the eastern border of the basin, outcrop-based columnar sections and subsurface data were used to build a stratigraphic section of the Pennsylvanian siliciclastic rocks, which run along more than $260 \mathrm{~km}$; five 3 rd order sequences and the corresponding system tracts were then identified. The occurrence of probable incised-valley systems is also suggested between the Serra da Cruz columnar section and borehole 9 locality. Furthermore, subsurface data related to the main evaporitic interval of the section, were analysed producing a model of the evaporite basin. The identification of key-surfaces and the Fischer plot technique allowed compilation of two stratigraphic sections roughly corresponding to the Pennsylvanian-Permian time span. In the 2nd order Pennsylvanian sequence, two 3rd order sequences were identified and six 4rd order sequece; at least two of them correspond to composite sequences. In the central portion of the basin, the above mentioned sequences are thicker and apparently devoid of significant hiatus. These sequences are thinner near the basin borders. Five or seven 4rd order sequences were also identified in the Permian age interval, displaying a sheet-like geometry with minor thickness variations. 


\section{AGRADECIMENTOS}

A todos os amigos, professores e funcionários do Instituto de Geociências da Universidade de São Paulo, que direta ou indiretamente contribuíram para a realização deste trabalho. E em especial:

Ao Prof. Dr. Antonio Carlos Rocha Campos pela orientação, amizade e confiança demostradas durante todos estes anos;

Ao querido e saudoso mestre Rodi Ávila Medeiros responsável pelo meu interesse na Geologia Sedimentar;

Ao Prof. Dr. Joel de Castro pelas críticas e sugestões durante e após o exame de qualificação, como também pelo amizade e apoio dispensados em inúmeras ocasiões;

Ao Prof. Dr. Cláudio Riccomini, coordenador do Programa de Pós-Graduação pelo apoio e compreensão dispensados durante a realização deste trabalho;

Aos Professores Jaziel Sá, Roberto Canuto, Paulo Santos, Kenitiro Suguio, Setembrino Petri, Vicente Fúlfaro, Benjamim Bley, Renato Sena, Augusto Pedreira, Rodolfo Dino, Wilson Lanzarini, Armando Coimbra e Murilo Lima pelo atendimento às mais variadas solicitações, importante contribuição à minha formação de professorgeólogo e pelo carinho e amizade demonstrados nestes anos de convivência, mesmo a distância;

Ao amigo pós-graduando Claudio Florêncio pelas excelentes discussões sobre sedimentação evaporítica e a professora e amiga Valéria Córdoba pela excelentes discussões sobre Estratigrafia de Seqüências;

Aos amigos pós-graduandos André Ferrari, Fernando Mancini e Alexandre Magno pelo apoio e amizade;

As secretárias Ana Paula (pós-graduação), Sonia Candeo e Lucia Ciccone (DPE) pelo atendimento cotidiano sempre gentil, solícito e competente, como também pela amizade dispensada;

A bolsista Jackson Barros (DG-UFRN) e Débora Sousa (PPPG-UFRN) pela ajuda na fase final de confecção da tese;

Ao meu irmão Ricardo Lima pelo apoio durante o trabalho de campo em várias etapas;

Ao Conselho de Pós-Graduação do IG-USP e ao Conselho Central de PósGraduação (CoPGr) pela compreensão referente ao prazo limite de entrega da tese;

A PETROBRAS por fornecer e permitir o uso de material indispensável a boa realização deste trabalho;

Ao Programa de Pós-Graduação de Geodinâmica e Geociências (CCET-UFRN) por financiar a confecção de parte do documento final;

Ao Departamento de Geologia (DG-UFRN) por permitir meu afastamento por dois anos para conclusão a tese;

Ao CNPq pela bolsa de estudos, parte importante do financiamento das atividades de campo;

A minha Mãe, Moema Lima, pelo financiamento de parte das atividades de campo, pelo amor, carinho e apoio nas horas difíceis;

A minha mulher Lucymara e meu filho Victor pela compressão, amor e apoio em todos os momentos desta difícil jornada;

Gostaria enfim, de agradecer a todos, envolvidos direta ou indiretamente no projeto da tese que por falha de memória não tenha citado nominalmente acima. 


\section{1- Introdução}

Neste trabalho é apresentada uma revisão bibliográfica simplificada sobre o conhecimento litoestratigráfico e dos ambientes deposicionais da Bacia do Parnaiba, com enfoque para as rochas depositadas durante o Permo-Pensilvaniano. São elaboradas seções estratigráficas levantados a partir dos dados obtidos pela Petrobrás (perfil composto, testemunho de sondagem etc.) e outras levantados na área de afloramento, utilizados para refinar o conhecimento sobre as unidades litoestratigráficas, os sistemas deposicionais interpretados e montar um arcabouço temporal para a sucessão estudada, em especial para a Seqüência Pensilvaniana.

Esta é a primeira tentativa de aplicação da Estratigrafia de Seqüências na montagem de um arcabouço temporal para a seqüência Permo-Pensilvaniana da Bacia do Parnaíba. Consequentemente, surgem alguns questionamentos de ordem teórica já que este paradigma estratigráfico foi criado a partir de dados obtidos em bacias de margem passiva e aqui será aplicado em uma bacia intracratônica. Que adaptações seriam necessárias para levar a termo esta aplicação, levando-se em conta também que a sucessão estudada é essencialmente evaporítica? Os dados atualmente disponíveis são suficientes para permitir este tipo de abordagem? Há realmente um ganho científico nesta abordagem em relação a abordagem estratigráfica tradicional?

De uma forma generalizada pode-se afirmar que o conhecimento atual a respeito da litoestratigrafia, bioestratigrafia e cronoestratigrafia da Bacia do Parnaíba é apenas razoável. Entretanto, esta deficiência não impossibilita a aplicação desses novos paradigmas estratigráficos. Como exemplo, tem-se o trabalho pioneiro de aplicação da Estratigrafia de Seqüências no Eo-Paleozóico na Bacia do Parnaíba (Della Fávera, 1990).

Procura-se aqui, com a elaboração desse arcabouço crono-estratigráfico, propiciar uma nova fase de investigações no Permo-Pensilvaniano da Bacia do Parnaíba, onde outras interpretações dos sistemas deposicionais, novos dados bioestratigráficos e de subsuperfície sejam utilizados para refinar este arcabouço, permitindo assim melhores correlações no âmbito local, regional e mesmo intercontinentais. 


\section{2- Objetivos e Metodologia}

\subsection{Objetivos}

O primeiro objetivo deste trabalho foi ampliar a identificação dos sistemas deposicionais da sucessão Permo-Pensilvaniana, enfatizando a seqüência Pensilvaniana, e mostrar suas relações espaciais. Em especial, na porção aflorante da Bacia do Parnaíba, de forma a ter mais elementos que propiciassem a identificação dos tratos de sistemas e limites de seqüência. Até o momento, foram interpretados os seguintes sistemas deposicionais: fluvial entrelaçado, campos de dunas eólicas, deltas, plataforma siliciclástica proximal e distal (retrabalhada por onda de tempestade), praia, planície de maré e plataforma carbonática.

A partir dos sistemas deposicionais interpretados, do reconhecimento dos elementos arquiteturais da Estratigrafia de Seqüências (principalmente as parasseqüências, conjuntos de parasseqüências e limite de sistemas), tanto nos perfis levantados em afloramentos quanto nos perfis de poços, montar um arcabouço cronoestratigráfico para a seqüência Permo-Pensilvaniana e, em mais detalhes, para a Pensilvaniana.

Comparar a sucessão carbonática-evaporítica do Permo-Pensilvaniano da Bacia do Parnaíba com sucessões permo-carboníferas das bacias do Solimões e do Amazonas. Comparar os ciclos do Pensilvaniano da Bacia do Parnaíba com os ciclotemas que ocorrem no médio continente americano.

\subsection{Metodologia}

Para maior segurança nas interpretações de antigas sucessões sedimentares deve-se reconhecer os três estágios de interpretação de Reading (1978): 1) sem um bom arcabouço regional é impossível realizar reconstruções paleogeográficas seguras, devendo-se neste caso elaborar hipóteses iniciais de trabalho que se aproximem dos modelos existentes e que permitam avaliar e direcionar os dados disponíveis; 2) o segundo estágio consiste no desenvolvimento de interpretações paleogeográficas gerais 
que mostrem uma orientação e posicionamento aproximado dos "cinturões ambientais". Seria a elaboração de um modelo conceitual no sentido de Hugget (1985), ou seja, uma imagem mental de um fenômeno da natureza na qual os detalhes supostamente essenciais do fenômeno sejam retidos e os detalhes supostamente acidentais sejam omitidos" que, grosso modo, consiste na interpretação preliminar dos sistemas deposicionais de uma determinada área; 3) finalmente, quando fosse possivel a identificação individual de cada elemento do sistema (por exemplo, a reconstrução, no tempo e no espaço, de cada canal fluvial e dos demais elementos individuais de um sistema fluvial) teria sido produzido uma interpretação realística. Apesar da intangibilidade do terceiro estágio interpretativo, ele serve para direcionar futuras pesquisas e levar ao refinamento do modelo elaborado.

A partir de prévias interpretação paleogeográficas gerais e elaboração de modelos consistentes, a aplicação dos conceitos da Estratigrafia de Seqüências permite a montagem de um arcabouço temporal refinado capaz de localizar no tempo e no espaço os sistemas deposicionais interpretados, ou mesmo afloramentos isolados, independentemente da presença de dados cronológicos adicionais. Contribuindo assim para diminuir a distância entre o modelo conceitual e a interpretação realística.

Foram estes alguns dos pressupostos teóricos que direcionaram a definição da metodologia aqui adotada para permitir a elaboração do arcabouço temporal para 0 Permo-Pensilvaniano da Bacia do Parnaíba, simplificada em três etapas. A primeira consistiu na identificação das áreas de afloramentos das formações de interesse (Piauí, Pedra de Fogo e Motuca) a partir da análise bibliográfica existente sobre a Bacia do Parnaíba e dos mapas geológicos dos estados do Piauí e do Maranhão, na escala de 1 : 100 000, elaborados respectivamente, pelo DNPM (Coutinho et al.,1986) e CPRM (Coutinho et al.,1995). A partir deste reconhecimento preliminar fez-se a subdivisão da área aflorante em três regiões (Fig.1.2.1): a primeira fica situada na porção nordeste e leste da bacia. $\mathrm{Na}$ porção nordeste há predominância de afloramentos da Formação Piauí, são encontrados bons afioramentos da seção inferior da Formação Pedra de Fogo, e afloramentos pouco expressivos da Formação Motuca; a região sudeste da bacia apresenta um relevo aplainado com exposições das formações Piauí e Pedra de Fogo restritas às margens de rios ou algumas escarpas de chapadões; a última, na região sul e sudoeste, onde se encontram ótimos afloramentos da Formação Pedra de Fogo e Motuca. A segunda etapa consistiu na seleção de afloramentos para análise de fácies e 


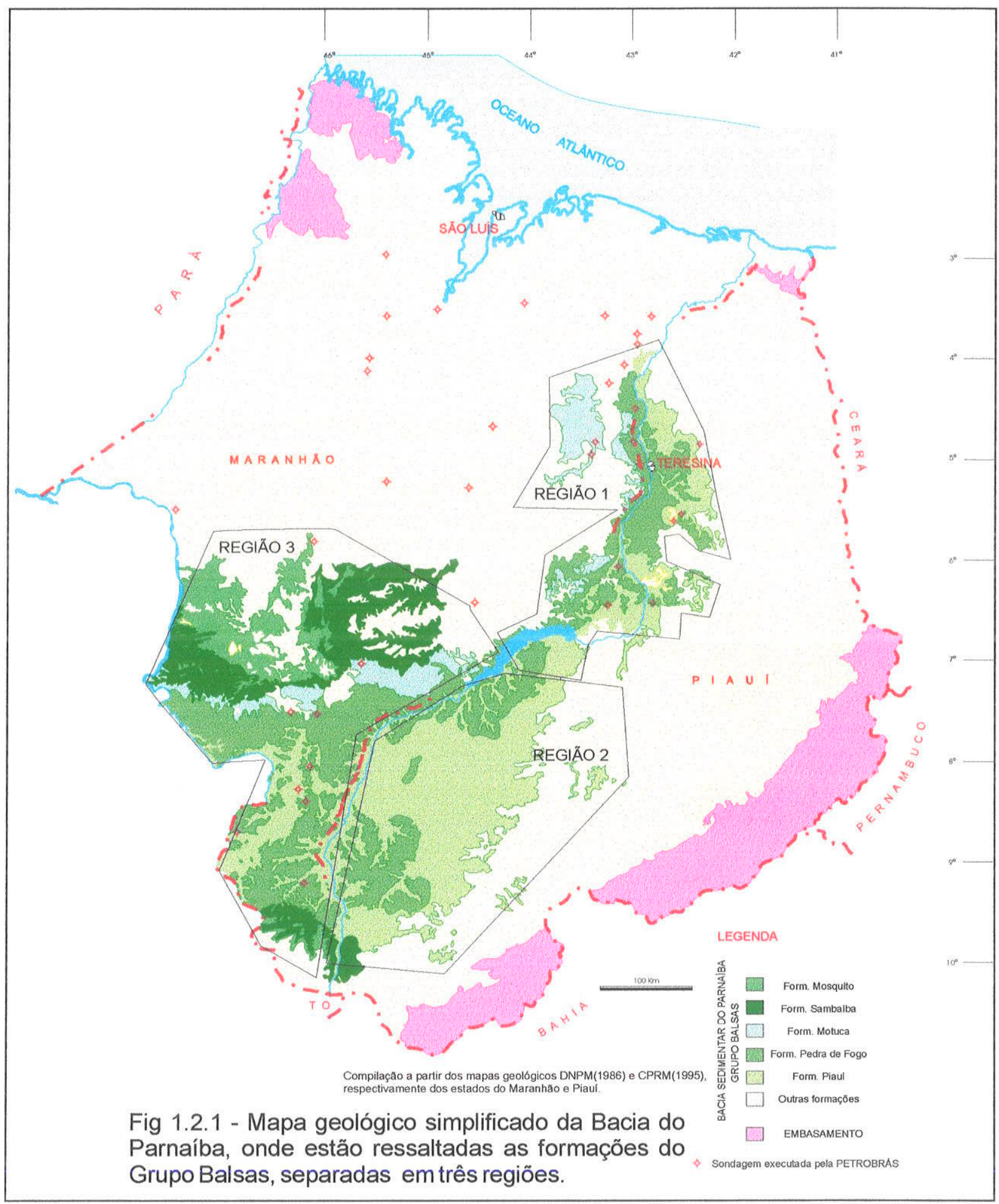


descrição de perfis verticais. Estes perfis foram levantados na escala de 1: 100 e em alguns casos particulares 1: 20. Sempre que possivel, foram levantados perfis paralelos e perpendiculares ao mergulho regional das camadas. Nesta etapa, foram levantados mais de $800 \mathrm{~m}$ de seções estratigráficas. Em regiões mais acidentadas foram levantados perfis com mais de $150 \mathrm{~m}$ de diferença de cota como, por exemplo, no município de São Francisco, MA. Nos locais selecionados foram realizadas análise de fácies que, segundo Anderton (1985), consiste em fazer a descrição e classificação de um corpo sedimentar, seguidas pela interpretação dos processos e do ambiente de deposição, geralmente apresentado na forma de um modelo de fácies. Anderton (op. cit.) chama a atenção para erros induzidos em virtude de inversões na ordem das etapas de uma análise faciológica. O procedimento deve seguir a seguinte ordem: 1) descrição detalhada; 2) subdivisão em fácies; 3) compilação das características de cada fácies; 4) dedução dos processos deposicionais de cada fácies; 5) exame das relações espaciais entre as fácies e o reconhecimento das associações faciológicas; 6) interpretação do ambiente da associação; 7) modelagem de fácies individuais. Walker (1976) enfatiza a necessidade do estudo faciológico sob a ótica holística, ou seja a interpretação genética de uma fácies isolada oferece menor precisão que a interpretação das várias fácies já descritas e vistas como um conjunto coerente, como sugerida na lei da Correlação de Fácies de Walther. A última etapa, consistiu na aplicação da Estratigrafia de Seqüências para a Seqüência Permo-Pensilvaniana da Bacia do Parnaíba, com ênfase para a seqüência Pensilvaniana. Nesta etapa, foi utilizada uma adaptação de procedimentos proposto por Becker (1997), em seu estudo no Permo-Carbonífero da Bacia do Solimões utilizando perfis radioativos. O passo inicial consiste na análise previa da seção em perfis de raios gama (a maioria dos poços é da década de 60/70 e só encontram-se perfis de raios gama), para montagem do arcabouço estratigráfico preliminar. Este arcabouço representaria o primeiro estágio de interpretação de Reading (1978), acima discutido, que juntamente com outras observações e pressupostos teóricos utiliza-se como base para verificar a aplicabilidade da Estratigrafia de Seqüências a sucessão sedimentar estudada. Escolhe-se, no passo seguinte, um ou dois poços de referência, onde a seção estiver mais completa, e avalia-se os critérios de padrões de freqüência da curva e da variação de espessura, separando-os. No passo seguinte faz-se a verificação de recorrência de intervalos com padrões cíclicos distintos, reconhecidos em relação a posição de folhelhos mais radioativos. Foram identificados os mesmos padrões encontrados por Backer 
(op.cit.): padrão simétrico, assimétrico transgressivo e assimétrico regressivo. Outra hipótese de trabalho proposta por Becker (op. cit.), e assumida neste trabalho, propõe que os folhelhos mais abrangentes, reconhecidos através da bacia por correlação, representam Superficies de Inundação Marinha Máxima. Complementando a proposta de Becker (op. cit.) foram ainda selecionados cinco poços, estrategicamente posicionados na bacia, para análise do comportamento da variação do padrão de empilhamento das parasseqüências com uso do Gráfico de Fischer. Com as informações obtidas é possivel fazer correlações mais seguras entre poços, identificar limites de seqüências e as principais superfícies de máxima inundação. A junção dos dados de poços (perfis e testemunhos), com os dados obtidos a partir de perfis levantados em afloramentos e a composição das técnicas aqui utilizadas confecciona-se seções estratigráficas ao longo da bacia, com identificação das seqüências que compõem esta sucessão sedimentar, elaboradas a partir de um modelo evaporítico moldado à luz da Estratigrafia de Seqüências. 


\section{3- Litoestratigrafia e ambientes deposicionais dos Grupos Serra Grande e Canindé}

\section{1 - Introdução}

Desde Small (1914), o arcabouço litoestratigráfico da Bacia do Parnaíba vem sendo delineado, cabendo a Kegel (1953), Mesner \& Wooldridge (1964), Aguiar (1971), Caputo \& Lima (1984) e Goes \& Feijó (1994) a elaboração básica do atual quadro estratigráfico da bacia. Os trabalhos pioneiros foram realizados pelo Conselho Nacional do Petróleo (Plummer et al., 1948; Campbel, 1948, 1949, apud Mesner \& Wooldridge, 1964), Departamento Nacional de Produção Mineral (Dequer, 1949, Dolianiti, 1954; Kegel, 1951,1953, 1956; Cruz et al., 1973; Leite et al., 1975; Abreu et al., 1977; Lima \& Leite, 1978, dentre outros). Posteriormente, com o início da prospeção petrolífera pela Petrobrás foi dado novo salto quantitativo e qualitativo no conhecimento litoestratigráfico, paleontológico e paleoambiental da Bacia do Parnaiba. Podem ser citados os trabalhos de síntese de Carrozi et al. (1975), Góes et al.(1990), ou outros importantes trabalhos de cunho específicos como Andrade \& Daemon (1974), Daemon (1974 e 1976), Della Fávera (1980, 1982, 1984,1990), Quadros (1982), Caputo (1984). Na âmbito das universidades algumas contribuições foram produzidas por pesquisadores da UFPA, UFRJ, UFPE, UFC, UFRN e USP, principalmente a partir do final da década de 70, dentre estes podem ser citados o de Suguio \& Fulfaro (1977), Mabesoone (1977), Campanha \& Rocha-Campos (1979), Faria Jr. \& Truckenbrodt (1980), Assis (1980), Coimbra (1983), Cordani et al., (1984), Faria Jr. (1984), Cunha (1986), Caldas et al., (1989), Lima Filho (1991a), Lima Filho \& Rocha Campos (1992), Lima Filho \& Rocha Campos (1993), Anelli et al., (1992), Anelli et al., (1993), Anelli (1994), lanuzzi (1994), Góes (1995), Lima Filho et al., (1995) e Lima Filho \& Anelli (1997).

A despeito do incremento no volume de informações sobre a bacia, esta permanece como uma das grandes áreas paleozóicas brasileiras menos conhecida até o momento. Provavelmente, deve-se isso às perspectivas pouco promissoras para óleo e gás verificadas preliminarmente pela Petrobrás, como também a distância geográfica dos grandes centros de pesquisas do país.

A Bacia do Parnaiba, também chamada de Meio Norte, Maranhão ou PiauíMaranhão tem os seus limites atuais compreendendo praticamente todo o Estado do Piauí e Maranhão, e parte dos estados do Tocantins, Pará e Ceará, correspondendo a 
uma área aproximada de $600.000 \mathrm{~km}^{2}$, contendo uma espessura de rocha sedimentar da ordem de $3,0 \mathrm{~km}$, das quais $2,5 \mathrm{~km}$ foram depositados predominantemente no Paleozóico. O pacote sedimentar com cerca de $0,5 \mathrm{~km}$ de espessura, é essencialmente mesozóico. A borda oeste da bacia é delimitada por falhas, enquanto a margem leste comporta-se como uma homoclinal suave com inclinação de 1 a 2 graus para oeste.

A partir de Figueiredo \& Gabaglia (1986), há uma tendência em considerar esta bacia como policíclica, inclusive com a separação em várias "sub-bacias". Para Góes \& Feijó (1994), o conjunto, envolvendo rochas do Paleozóico, Mesozóico e Cenozóico constitui a denominada Província Sedimentar do Meio Norte do Brasil, com história policíclica, compartimentada em diferentes bacias com gênese e idades distintas, denominadas de Bacia do Parnaíba, Bacia das Alpargatas, Bacia do Grajaú e do EspigãoMestre. Segundo Góes \& Feijó (op. cit.) a Bacia do Parnaiba, com uma área de 400.000 $\mathrm{km}^{2}$ e $3.000 \mathrm{~m}$ de espessura de rochas siliciclásticas e químicas, representa a porção remanescente de extensa sedimentação afro-brasileira, envolvendo rochas depositadas em três grandes ciclos transgressivos-regressivos desde 0 Siluriano até a continentalizaçâo da bacia no Triássico representados pelos grupos Serra Grande, Canindé e Balsas (Fig.1.3.1). Já a Anfíclise das Alparcatas, com área de $70.000 \mathrm{~km}^{2} \mathrm{e}$ $200 \mathrm{~m}$ de espessura é resultado dos eventos precoces da abertura do Atlântico Sul, no Jurássico, quando ocorreu o abatimento da região central da Província do Meio Norte, com instalação de um sistema de rifts que contém rochas sedimentares fluvios-lacustres (formações Pastos Bons e Corda) e rochas vulcânicas associadas, de idade jurássica a eocretácea (formações Mosquito e Sardinha). No Cretáceo, com a efetiva abertura do Atlântico Sul, foram gerados novos depocentros, ao norte denominado Bacia do Grajaú, com espessura de $800 \mathrm{~m}$ e com área de $130.000 \mathrm{~km}^{2}$, envolvendo sedimentação eólicolacustre (formações Codó, Grajaú e Itapecuru), e ao sul, denominado Bacia do EspigãoMestre, com área de $170.000 \mathrm{~km}^{2}$ e $400 \mathrm{~m}$ de espessura, envolvendo depósitos predominantemente fluvio-eólicos (Grupo Areado e Formação Urucuia). A Bacia do Parnaíba está inserida na Plataforma Sul-Americana, sobreposta a um embasamento cristalino cratonizado após o término do evento Brasiliano, datado do final do Proterozóico e início do Cambriano. Esta bacia foi classificada por Asmus \& Porto (1973) como cratônica tipo I, por Brito Neves (1983) como intracratônica, e por Figueiredo \& Raja Gabaglia (1986) como fratura interior, passando para sinéclise interior continental. Estas 
classificações, não excludentes, refletem a evolução dos conhecimentos sobre a origem

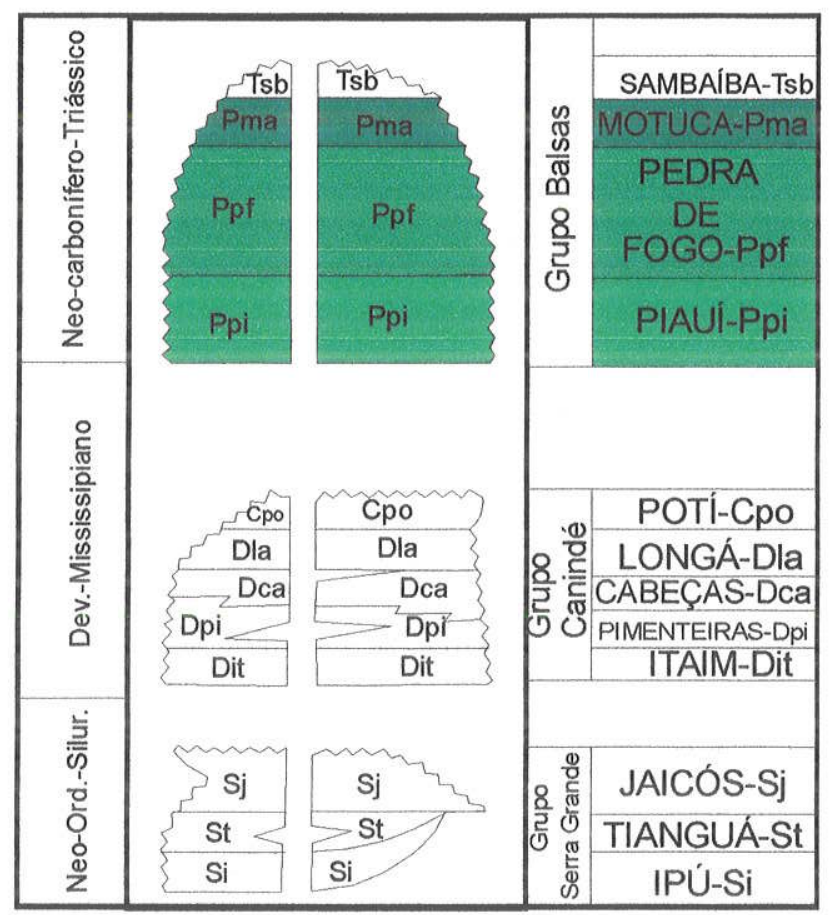

Fig.1.3.1- Carta cronoestratigráfica do Paleozóico da Bacia do Parnaíba, em destaque o Permo-Pensilvaniano (simplificado de Goes \& Feijó, 1994)

e evolução de bacias paleozóicas, onde esta última classificação, mais direcionada para a industria de petróleo, tem como principal característica a informatização e possibilidade de constante atualização dos dados, inclusive permitindo mudança na classificação em função da aquisição de novos dados. Tectonicamente, a bacia limita-se ao norte com as bacias de São Luís e de Barreirinhas, separadas pelo Arco FerrerUrbano Santos, originado no Neocomiano (Resende \& Pamplona, 1970). A nordeste, limita-se com a Fossa de Marajó, obstada pelo Arco de Tocantins. Ao sul e ao sudeste, tem-se as bacias de São Francisco e Lençóis, separadas da bacia do Parnaíba pelo Arco do Médio São Francisco. As áreas cratônicas vizinhas incluem, ao norte, o craton de São Luís, separados pelo Arco Ferrer-Urbano Santos; a leste, o Craton do Amazonas, separados pelo Arco do Tocantins; e a sudeste, o Craton do São Francisco separado pelo Arco do Médio São Francisco (Cunha, 1986). 


\section{2- Grupo Serra Grande}

O termo Serra Grande foi proposto inicialmente por Small (1914), de uma forma generalizada, para descrever uma seção com espessura máxima de $900 \mathrm{~m}$ envolvendo arenitos, conglomerados e calcários da Bacia do Parnaíba e calcários da Bacia de Ubajara. Kegel (1953) considerou como formação o pacote inferior da bacia, excluídos os carbonatos, baseado na presença de uma discordância angular que separa as rochas destas duas bacias. Carozzi et al.(1975) elevaram esta formação à categoria de grupo. Entretanto, coube a Caputo (1984) e Caputo \& Lima (1984) a proposição estratigráfica mais aceita hoje em dia. Nestes termos, o Grupo Serra Grande foi subdividido em três formações: Ipú, Tianguá e Jaicós. A unidade foi uma das mais discutidas quanto a idade, subdivisão litoestratigráfica e ambientes de sedimentação.

O termo Ipú foi introduzido por Campbell (1948, apud Batista et al., 1984), que dividiu a Formação Serra Grande em duas camadas, e usou este termo para se referir a camada inferior de conglomerado. Coube a Caputo e Lima (1984) e Caputo (1984) 0 resgate do termo, agora na categoria de formação, cuja espessura máxima atinge até 300 $\mathrm{m}$, formada por pacotes de arenito, conglomerado, arenito conglomerático e diamictito, com maior espessura na região NE da bacia. Apenas um fóssil foi encontrado até o momento, tentativamente identificado como Arthrophycus sp. por Moore (1963, apud Caputo, 1984) o qual poderia indicar idade Ordoviciano-Siluriano. Daí, a interpretação da sua idade de deposição ter variado ao longo do tempo, entretanto, tem-se observado uma tendência nos artigos mais recentes em considerar sua idade de deposição como ordoviciana a siluriana, como mostrado a seguir: cretácea (Small, 1914); carbonifera (Plummer et al.,1948, apud Batista et al., 1984); eodevoniana (Blankennagel, 1952, apud Caputo (1984); Kegel, 1953; Quadros, 1982); siluro-devoniana (Muller, 1962; Mesner \& Wooldridge, 1964; Aguiar, 1971); ordoviciana ou eo-siluriana (Moore, 1963 apud Caputo, 1984); Brito 1969; Bigarella, 1973; Caputo, 1984; Caputo \& Lima, 1984). Estes valores foram sugeridos principalmente a partir de correlações com unidades litoestratigraficas supostamente crono-equivalentes, em outras bacias, ou por extrapolação, com base nas idades obtidas para as formação fossiliferas sobrejacentes. Os ambientes deposicionais reconhecidos na Formação Ipu e formações equivalentes, espahadas no NE do Brasil (e.g., na Bacia do Araripe e nas bacias de Jatobá e Sergipe-Alagoas), são sugeridos 
como associados a leques aluviais de origem glacial (depósitos de sandur e out-wash) nas áreas de afloramento e deposição em leques deltaicos no interior da bacia, e plataforma marinha rasa, nas partes distais (Caputo, 1984; Caputo \& Lima, 1984). Entretanto, as melhores exposições, na região centro-leste da Bacia do Parnaíba e mesmo na Bacia do Araripe (Formação Cariri) correspondem a depósitos de rios entrelaçados.

O termo Tianguá foi proposto por Rodrigues (1967, apud Batista et al., 1984), se referindo aos folhelhos e arenitos finos que ocorrem sobrepostos a Formação Ipú, na categoria de membro. Carozzi et al. (1975) elevaram a categoria de formação. Caputo (1984) subdividiu esta formação, cuja espessura máxima em subsuperfície é de $270 \mathrm{~m}$, em três membros denominados de 1, 2 e 3 . Constitui-se de folhelhos pretos a cinza-escuro e arenitos com intercalações de folhelhos. Os macrofósseis desta unidade resumem-se a graptólitos do gênero Monograptus encontrados no testemunho 53 do poço 2-BJ-1-PA da Petrobrás (Caputo \& Lima, 1984). A idade siluriana atribuida à formação é a mais aceita. Segundo Caputo \& Lima (1984) as rochas desta unidade foram depositadas em ambiente marinho raso, durante a fase de máxima extensão da transgressão glacioeustática siluriana, de extensão mundial, que se seguiu à fusão das massas de gelo do norte da África.

A Formação Jaicós foi proposta por Plummer et al.,(1948) para designar camadas de arenitos e conglomerados que afloram na cidade de Jaicós, PI. O limite superior desta formação é discutível, uma vez que suas litologias se assemelham aos arenitos da Formação Itaim, dificultando a identificação da provável discordância entre estas formações, como demonstrado por Caputo \& Lima (1984). Não foram encontrados macrofósseis na unidade, cuja idade é também controvertida; Muller (1962, 1964 apud Caputo, 1984), estudando esporos encontrados em folhelhos intercalados aos arenitos, em amostra de subsuperfície, indicou idade Siluriano para a unidade. Carozzi et al. (1975) consideram-na como eo e mesoemsiana (Devoniano). Quadros (1982), com base em acritarcas, atribui-lhe idade eodevoniana (gediniana-singeniana) ou eosiluriana (neolandoveriana a venlockiana) e Caputo \& Lima (1984) sugerem uma idade venlockiana. Em afloramento, as rochas desta formação foram interpretadas como envolvendo depósitos fluviais (Kegel, 1953; Beurlen, 1965); plataforma rasa (Bigarella; 1973; Mabesoone, 1978); frente deltaica Carozzi et al., 1975; leques aluviais e frentes de leques deltaicos (Caputo \& Lima, 1984). 


\section{3- Grupo Canindé}

O Grupo Canindé, proposto por Rodrigues (1967, apud Caputo 1984), compreendia as formações Pimenteiras, Cabeças e Longá. Caputo (1984) acrescentou a Formação Itaím a este grupo. Goes et al. (1990) incluiram também a Formação Potí. Considera-se aqui o Grupo Canindé conforme Goes et al. (op. cit.), representado pelas formações Itaim, Pimenteiras, Cabeças, Longá e Poti, cuja deposição ocorreu do Devoniano ao Mississipiano, é constituído essencialmente de arenitos e folhelhos de origem transicional ou marinha.

O termo Itaím foi proposto por Kegel (1953) na categoria de um membro da Formação Pimenteiras. Blankennagel (1954, apud Batista et al., 1984) posicionou o Membro Itaím no topo da Formação Serra Grande. Caputo (1984) e Caputo \& Lima (1984) consideram como a base do Grupo Canindé. A Formação Itaím atinge uma espessura superior a $250 \mathrm{~m}$, consistindo de arenitos com folhelhos e siltitos intercalados (Caputo, 1984). A idade desta formação é atribuída com base em poucos fósseis identificados por Kegel (1953) como, por exemplo, Spirophyton sp (que na America do Norte ocorre do EoDevoniano ao Pensilvaniano); Amphigenia sp (Eo ao Meso-Devoniano), como EoDevoniano (Caputo, op. cit). Esta unidade é interpretada como depositada sob forte influência deltaica (Caputo, 1984).

O termo Pimenteiras foi introduzido por Small (1914) para caracterizar um pacote de folhelho que ocorre na cidade de Pimenteiras. A formação caracteriza-se por uma seqüência granocrescente para cima, organizada verticalmente em ciclos, também de granocrescência ascendente, predominantemente argilosa, de 10 a $30 \mathrm{~m}$ de espessura (Della Favera, 1984). O topo dos ciclos é reconhecido pela presença de corpos de arenitos de 3 a $5 \mathrm{~m}$ de espessura, com geometria de barras ou lobos. O comprimento destes corpos atinge $100 \mathrm{~m}$. O topo destes grandes ciclos é marcado por extensos hardgrounds com icnofósseis. A característica principal das barras é a estratificação cruzada tipo hummocky. Acredita-se que a origem das barras de plataforma ou lobos esteja associada a processos ligados a ondas de tempestade. Estes processos implicam uma deposição a partir de correntes de densidade, sob fluxo oscilatório (Della Favera, op. cit.). O conteúdo paleontológico desta formação representado por trilobites 
(Metacryphaeus), braquiópodes (Chonetes) indica seguramente um ambiente marinho de deposição e sugere idade Devoniano (Kegel, 1953).

O termo Formação Cabeças foi proposto por Plummer et al.,(1948), o qual subdividiu nas camadas: Ipiranga, Oeiras e Passagem. A formação é composta principalmente por arenitos médios, quartzosos, ocasionalmente, arenitos grossos a conglomeráticos, ou finos com menor maturidade mineralógica e textural. Os arenitos apresentam-se freqüentemente com geometria sigmóide, formando individualmente corpos alongados que sofreram acresção lateral (Della Favera, 1984). As estruturas sedimentares mais comuns são os conjuntos de estratificação cruzada duplamente tangencial (ou "sigmoidal"). As "sigmóides" (Della Favera, op. cit.) caracterizam-se por base e topo assintóticos, as quais migram lateralmente por grande extensão. Feições de escorregamento e de escape de água são comuns. Os corpos arenosos estão intercalados com seções argilosas onde se encontram estratificação lenticular (linsen), ondulada (wavy) e flaser, dispostas em padrão cíclico. Della Favera (1980) interpreta para a Formação Cabeças um sistema de campo de crista de areia (sand ridges fields), semelhante aos que ocorrem nas plataformas continentais modernas. A paleontologia também sugere um ambiente marinho, dada a abundância de trilobites, braquiópodes etc. (Kegel, 1953; Caldas et al.,1987). Fortes (1996), mostra a existência de contribuição fluvial associada a planície de maré, na região de Sete Cidades, PI, na deposição desta unidade.

A Formação Longá foi definida por Albuquerque \& Dequer (1946), que atribuiram o nome a folhelhos escuros que ocorrem no leitó do rio Longá, em Campo Maior-PI. Sua espessura média de $100 \mathrm{~m}$, é bem individualizada em superfície, em subsuperficie e nos perfis elétricos. É constituída de um Membro Inferior, de folhelho ou siltito; um Membro Médio, de arenitos e siltitos e um Membro Superior de folhelho. $O$ contato com a Formação Cabeças é feito ora com a fácies arenosa ora com paraconglomerados, enquanto o contato superior com a Formação Poti é gradacional (Aguiar, 1971). Mesner \& Wooldridge (1964) consideram esta formação como depositada em ambiente marinho raso, e caracterizada por camadas contorcidas e abundantes perfurações por vermes. Caputo (1984) considera que as rochas desta formação foram depositada em ambiente marinho, onde a porção média é caracterizada por frentes deltaicas e depósitos arenosos marinhos rasos. Onde os depósitos da porção média não ocorrem são encontrados depósitos interdeltaicos juntos com fácies de praia. Na porção superior ocorre um folhelho 
transgressivo com indicação de mais restrição que o folhelho inferior (Caputo, 1984). A idade de deposição foi sugerida por Kegel (1953) como Neo-Devoniano, com base na fauna marinha encontrada.

O termo Poti foi inicialmente citado por Small (1914), entretanto, coube a Paiva \& Miranda (1937) a denominação de Formação Poti. Mesner \& Wooldridge (1964) definem esta formação como composta de arenitos e siltitos com gradação normal, carbonáceos com intercalações de conglomerados e finas lâminas de carvão. Consideram sua porção inferior como depositada em ambiente marinho, seguida de condições continentais e deltaicas. Aguiar (1971) subdivide a formação em dois membros: Inferior e Superior. O primeiro compreende rochas predominantemente areníticas conglomeráticas com intercalações de pelitos, enquanto o Membro Superior, mais fino e caracterizado por arenitos com intercalações de folhelhos, com restos vegetais e leitos de carvão. Cruz et al. (1973) identificam depósitos fluviais meandrantes na porção superior da formação. Della Favera (1980) detalhou a interpretação original de Mesner \& Wooldridge (1964), ressaltando a presença de barras de marés e de barras de desembocaduras em sistemas deltaicos. Della Favera (op. cit.) mostra também a ação de tempestade nestes depósitos. Góes (1995) separa os depósitos desta formação em plataformais e litorâneos. 
4- Evolução dos conhecimentos e novas informações litoestratigráficas e dos ambientes deposicionais da Seqüência Permo-Pensilvaniana da Bacia do Parnaíba

O Grupo Balsas, proposto por Goes et al. (1990), encerra a porção paleozóica da bacia e inclui os primeiros depósitos de idade triássica, compreende as formações Piauí, Pedra de Fogo, Motuca e Sambaíba. Para o presente trabalho serão abordadas apenas as formações Piauí, Pedra de Fogo e Motuca que compreendem a Seqüência PermoPensilvaniana. A Formação Sambaíba, depósitos areníticos, de origem predominantemente eólica, assentados discordantemente sobre a Formação Motuca corresponde a outra seqüência, fugindo do escopo da presente tese.

\subsection{Formação Piauí}

O termo Série Piauí foi usado originalmente por Small (1914) para designar pacotes de rochas sedimentares que ocorrem nos estados do Piauí e Maranhão, identificadas como arenitos e folhelhos inferiores, arenitos e folhelhos intermediários e arenitos vermelhos superiores. Duarte (1936), estudando o conteúdo paleontológico do poço 125, a chamada "Sondagem de Theresina", separou os estratos contendo os biválves Aviculopecten, Edmondia, Spirifer e Orbiculoidea, que atribuiu ao Andar Uraliano do Carbonífero, de camadas de origem continental caracterizadas por Palmatopteris furcata que atribuiu ao Andar Westphaliano. Oliveira \& Leonardos (1943) restringiram o termo para Formação Piauí, representando apenas as camadas carboníferas do Pensilvaniano. Dequech (1950) definiu os limites estratigráficos da Formação Piauí, compreendidos entre os arenitos e siltitos da Formação Poti e o silex basal da Formação Pedra de Fogo.

Mesner \& Wooldridge (1964) dividiram a Formação Piauí em dois membros. O inferior é caracterizado por arenitos róseos, maciços com raras intercalações de folhelhos, continental, enquanto o superior corresponde a arenitos vermelhos e leitos de sílex, de origem marinha.

Com objetivo de avaliar o potencial de carvão na Bacia do Parnaíba, Cruz et al. (1973) executaram trabalhos estratigráficos sistemáticos, com levantamento de 45 seções nas formações Poti e Piauí, perfazendo uma espessura composta de $2.100 \mathrm{~m}$ de rochas 
sedimentares descritas, acompanhados de perfurações de cinco poços estratigráficos, entre os vales do Gurguéia e Urucui-Preto no sul do Piaui. Estes autores apresentaram importante contribuição ao conhecimento litoestratigráfico da Formação Piauí. Para Cruz et al. (op. cit.) o intervalo inferior (ou seção basal) da formação é muito bem exposto a leste da área estudada, nas escarpas da chapada que margeia o rio Gurgueia. Entre Bertolínia e Cristino Castro (Piaui) a unidade exibe mais de $100 \mathrm{~m}$ de espessura, diminuindo para oeste, onde restringe-se a apenas 73 metros no furo 1-UR-2-PI da CPRM. Neste intervalo, predominam arenitos róseos, amarelados e esbranquiçados, variando de textura fina a grossa, ocorrendo até conglomeráticos, de má a baixa seleção, com grãos subangulares a subarredondados. São feldspáticos, caulínicos, podendo ocorrer intercalados com camadas não muito espessas de siltitos e folhelhos cinza e avermelhados. O intervalo médio, na área estudada, compreende uma alternância de siltitos e argilitos avermelhados com arenito fino esbranquiçado, geralmente calcíferos e micáceos. Apresenta uma espessura média de $30 \mathrm{~m}$. O intervalo superior está restrito ao extremo oeste da área, no vale do Riacho Correntes, com espessura de $120 \mathrm{~m}$. Corresponde a um pacote predominantemente de arenitos creme a amarelados ou avermelhados, finos, bem selecionados, esféricos, pouco friáveis, pouco feldspáticos, com intercalações de silex maciço ou oolítico. Os três intervalos da Formação Piauí restringem-se a região centro-sul da área do projeto. Para o norte, a partir da altura de Landrí-Sales, a unidade tem expressão fisiográfica diversa. Ao sul da área estudada, predominam chapadões com escarpas verticais pronunciadas. Já ao norte de LandriSales, a topografia mostra-se aplainada, sobressaindo-se apenas os chapadões formados pela Formação Pedra de Fogo. Ali ocorrem espessas coberturas arenosas e poucos afloramentos. Ao norte, no furo UR-5-PI da CPRM, a porção basal e a superior são constituídas por lamitos, enquanto a porção média é mais arenosa. Para Melo \& Porto (1965, apud Cruz et al., 1973) a linha Uruçuí-Jerumenha, PI marca o limite da ocorrência das fácies mais argilosas e calcárias da parte superior da Formação Piauí, que não se prolonga para sudeste. Não foram encontrados aqui micro ou macrofósseis. A má seleção do material e o grau de imaturidade dos arenitos sugerem uma deposição rápida, com transporte curto, por rios com grande capacidade de carga, originados em áreas regularmente elevadas, indicando acentuado levantamento da borda da bacia, nesta época. Os intervalos inferior, médio e superior exibem características fluviais. Todavia, referem-se os autores à presença de depósitos eólicos na porção superior da formação, 
que consideram correspondente ao "Arenito" Saraiva da região de Teresina. Não foi notada a presença de rochas depositadas em ambiente marinho, exceto alguns niveis de silex com oólitos (Cruz et al., op. cit.).

Abreu et al. (1977) mapearam uma quadrícula na porção S-SE da Bacia do Parnaíba (folha SB-23-YD), na região de Balsas-MA, e apresentaram um mapa geológico na escala 1:100.000. Estes autores dividem o Membro Superior da Formação Piauí, 0 único aflorante na área mapeada, em duas subunidades, também denominadas de inferior e superior, seguindo os mesmos critérios adotados por Aguiar (1971). Corresponde o conjunto a intercalações de arenitos, siltitos e folhelhos. Este membro aflora com espessura de até $120 \mathrm{~m}$ na porção sul da áreá mapeada, nos paredões das serras Geral, Branca e do Chinelo. Para esses autores, o ambiente deposicional das rochas que constituem a Formação Piauí é predominantemente continental. No Membro Inferior predominaram condições de sedimentação eólica e fluvial, enquanto no Membro superior fluvial, deltaica e mais restritamente marinha. Lima Filho (1991a) redefiniu os limites estratigráficos da Formação Piauí em subsuperficie, considerando o limite com a Formação Pedra de Fogo uma camada de anidrita de extensão bacial. Descreveu e interpretou as rochas sedimentares da Formação Piaú na borda leste da bacia, caracterizou a presença de ação eólica, durante sua deposição, indicando a predominância de paleocorrentes para SW e NW na porção central e sul, na porção NE da pacia as paleocorrentes indicam sentido de paleoventos preferencialmente para NW. Foram descritas também rochas carbonáticas e evaporiticas. As primeiras foram interpretadas como plataformas carbonáticas, pouco expressivas, correspondentes aos calcários que ocorrem na porção superior da formação, na borda NE da bacia. Este autor admite um modelo de bacia evaporítica para a Formação Piauí, com duas prováveis entrada do mar, a partir da Bacia do Amazonas e por onde hoje se situa a ilha de Marajó. Foi apresentado também uma revisão bibliográfica sobre a idade de deposição dos estratos da Formação Piauí. As idades mais refinadas foram obtidas por Campanha \& Rocha Campos (1979), no Calcário Mocambo. Principalmente, com base na assembléia de conodontes, cuja amplitude está restrita ao Pensilvaniano Médio.

Lima Filho (1991b) separou as rochas carbonáticas da Formação Plauí em dois tipos principais: o tipo 1 corresponde a carbonatos biodetríticos, calcíticos, as vezes parcialmente silicificados, no geral, abundantemente fossilifero, com espessura média de $1 \mathrm{~m}$, aflorando na porção NE da bacia, especialmente no município de José de Freitas, PI. 
Incluem-se aqui depósitos de plataforma carbonática rasa (calcário Mocambo, Contendas e Meruoca), de planície de maré (Vidalgo, Carimã e Bom Lugar) e lagunar (Esperança). $O$ tipo 2 corresponde a calcários químicos, geralmente afossiliferos, comumente associados a anidrita.

Lima Filho et al.(1995), com base no mapeamento geológico de uma área de 200 $\mathrm{km}^{2}$ (na escala de 1: 25 000) na borda NE da bacia, levantamento de seções estratigráficas e descrição de afloramentos isolados reconhecem que na porção inferior da Formação Piauí (na região de Teresina/José de Freitas/União-PI) a sedimentação deuse num contexto ambiental marinho/costeiro, onde foram identificados depósitos de dunas eólicas, de plataforma carbonática, de deltas e de marés.

A maioria dos trabalhos que discute os ambientes deposicionais da Formação Piauí considera seus depósitos inferiores como sendo de origem continental.(p.e. Abreu et al., 1977). Entretanto, desde Lima Filho (1991), Lima Filho et al.,(1995), Ribeiro \& Melo (1996) são descritos também depósitos costeiros na borda leste da bacia.

São apresentadas aqui algumas descrições de afloramentos e seções geológicas (Alegria, Baixa Fria, Santa Rita e Serra da Cruz) com o objetivo de facilitar a visualização das variações faciológicas e a diversidade litoestratigráfica das formações Piauí, Pedra de Fogo e Motuca, como também mostrar a relação espacial entre elas. Por uma questão operacional as descrições estão separadas por unidade litoestratigráfica. Os aspectos cronoestratigráficos (tratos de sistemas e seqüências) serão tratados em um item adiante.

$\mathrm{Na}$ rodovia que liga as cidades de Altos e Beneditinos no Piaui ( $\mathrm{Br} .223)$, encontram-se afloramentos da Formação Piauí em escarpas com razoável desnivel, com pouco solo e vegetação onde foram levantadas três seções colunares (Fig. 1.4.1, 2.4.1, 3.4.1). Uma das seçōes colunares (Baixa Fria) foi utilizada também para integralizar a seção estratigráfica da borda leste da bacia, envolvendo outros afloramentos e os dados de subsuperficie. Estas seções colunares estão apresentadas individualmente e depois compondo as seções estratigráficas.

\section{Seção colunar da Baixa Fria}

A seção colunar sedimentar denominada de Baixa Fria (Fig. 1.4.1) foi dividida em 10 fácies: a fácies arenito médio a grosso com estratificação cruzada incipiente (AmgCi), arenito fino a médio com estratificação plano-paralela (AfmPp), arenito fino a médio 


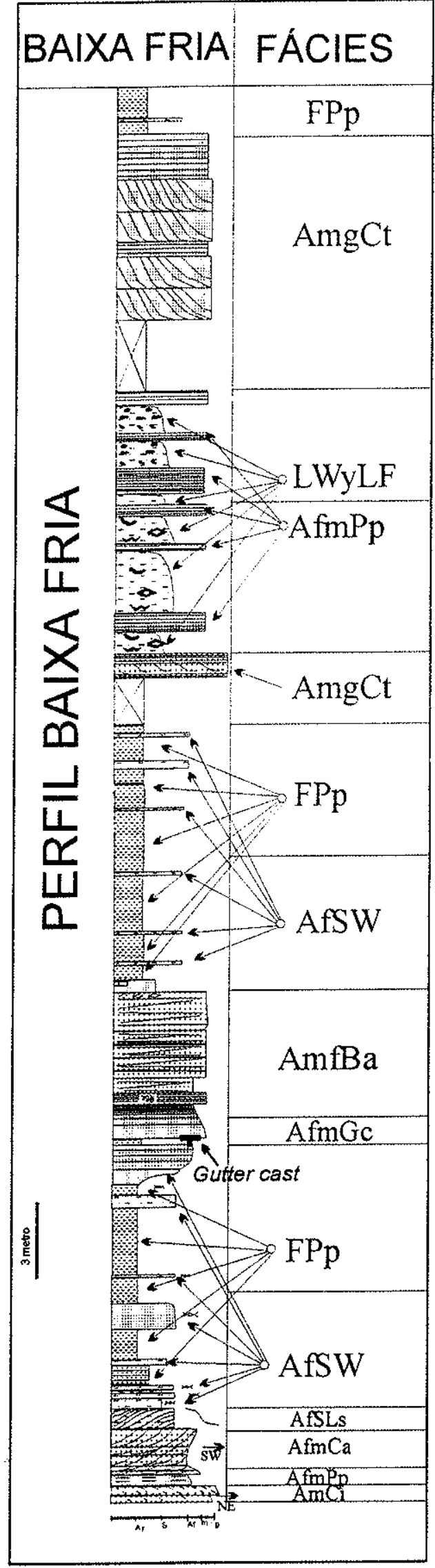

Fig. 1.4.1- Textura, estrutura e relação entre as fácies da seção colunar da Baixa Fria. As descrições das fácies estão no texto.

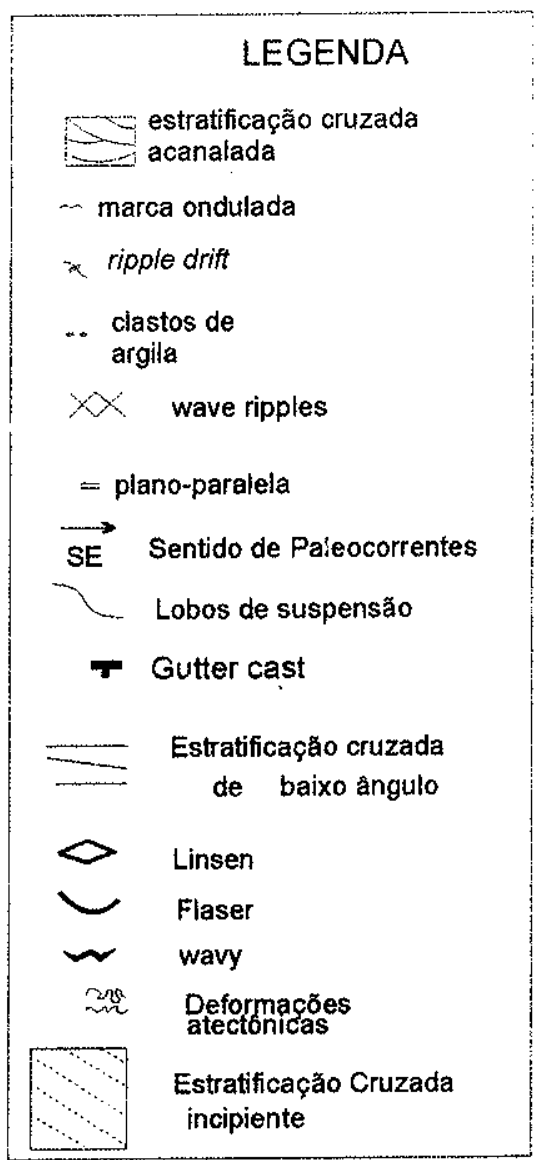


com estratificação cruzada acanalada (AfmCa), arenito muito fino a siltito com lobos de suspensão (AfSLs), arenito muito fino a siltito com marcas onduladas geradas por ondas (wave) (AfSW), folhelho com laminação plano-paralela (FPp), arenito médio a fino com gutter cast (AmfGc), arenito médio a fino com estratificação cruzada de baixo ângulo (AmfCba), arenito médio a grosso com estratificação cruzada tangencial na base (AmgCt), lamito com estratificação ondulada, estratificação lenticular e estratificação flaser (LWLF).

A fácies AmgCi consiste de arenito médio com cruzadas incipientes, exibindo na porção superior lentes conglomeráticas, com seixos de quartzo e de feldspato parcialmente intemperizados, com paleocorrentes indicando sentido de transporte para NE. A fácies AfmPp é representada por arenito fino a médio com estratificação planoparalela, ocorrendo restritamente, em contato normal com a fácies anterior, enquanto a fácies AfmCa corresponde a um corpo arenitico de textura média na base, passando para fino na porção superior da camada, mostrando estratificação cruzada acanalada de pequeno porte, com sentido predominante das paleocorrentes para SW. A porção mais fina deste conjunto de fácies inferiores, é caracterizada por camadas com estratificação clinoforma (fácies AfSLS). A fácies AfSW que ocorre intercalada com a fácies FPp é caracterizada por camadas, algumas vezes métricas, mostrando truncamento de onda de pequeno porte (wave ripples), enquanto a fácies FPp está representada por folhelhos vermelhos e verdes, laminados. O conjunto mostra uma tendência a apresentar lâminas e conjuntos de lâminas com maior espessura para o topo. Com espessura de $2,9 \mathrm{~m}$, a fácies AmfGc consiste de arenito predominantemente médio, disposto em camadas centimétricas $(2 \mathrm{~cm})$ com granocrescência ascendente, separados por filmes de siltito/argilito. Mostram, localmente, deformações, marcas onduladas e estratificação flaser (flaser bedding). Na base do corpo arenoso são encontradas estruturas de marcas de sola tipo gutter cast (fácies AmfBa) com espessura de 4,6m, correspondendo a um arenito de textura fina a média, friável, bem selecionado, limpo, com estratificação cruzada de baixo ângulo ressaltadas principalmente por minerais pesados. Ocorrem também camadas de arenitos finos, ricas em minerais pesados, com estratificação de baixo ângulo. A fácies AmgCt representa um arenito quartzosos de textura média a grossa, cimentado por óxido de ferro, com estratificação cruzada, tangencial na base, com suave variaçäo do ângulo do mergulho, separados por delgadas camadas de argilito formando bundlles e pares conjugados de argila (mud couplets). A associação de siltito, ora lamoso ora arenítico, intercalados com arenitos de textura fina a muito fina, marcada 
pela abundância de estratificação lenticular (linsen), estratificação ondulada (wavy) e estratificação flaser está representada pela fácies LWLF. Na porção inferior é maior a presença de intercalações de arenitos finos, com marcas onduladas e lâminas de argilito nas calhas (estratificação flaser), para o topo predominam estratificação ondulada e estratificação lenticular num padrão gradacional normal.

A porção inferior da seção foi interpretada como sistema fluvial em processo de afogamento, cobertos por depósitos tempestitos de plataforma. Acima, ocorrem depósitos de praia sobrepostos por pelitos de pró-delta, num caráter retrogradacional. Na porção mais superior ocorrem depósitos de marés. Estas informações estão detalhadas no item 5.1 (Fig. 1.5.1).

\section{Seção colunar Alegria}

Na seção colunar Alegria foram individualizadas 11 fácies (Fig. 2.4.1 e 3.4.1), denominadas de: arenito médio, maciço (AmM), arenito médio a grosso com estratificação cruzada acanalada (AmgCa), arenito fino com laminação plano-paralela (AfPp), arenito médio com estratificação cruzada acanalada (AmCa), lamito intercalado com arenito fino mostrando marcas onduladas (LafMo), arenito fino com estratificação plano-paralela e laminação cavalgante (ripple drift) (AfPpRd), arenito conglomerático a fino com truncamento (AcfT), arenito fino com lobos de suspensão (AfLs), arenito fino intercalado com siltito mostrando marca de onda (AfSW), arenito fino com plano-paralela $(A f P p)$, lamito com laminação cavalgante (LRd) e folhelho com estratificação planoparalelo. A fácies AmM corresponde às camadas inferiores do pacote, representados por arenito de textura média, sem estrutura sedimentar visível, enquanto a fácies AmgCa ocorre intercalada com a fácies AmM, mostrando granodecrescência ascendente e sentido de paleocorrente variando de NNW, NNE e NW, identificadas em estratificações cruzadas acanaladas de médio porte. Em contato erosivo com as fácies superiores, ocorre a fácies sedimentar AfPp, caracterizada por arenito finos com laminação planoparalela. Sotoposta à superfície erosiva, a fácies AmCa é caracterizada por arenito de textura média, com estratificação cruzada acanalada, mostrando sentido de paleocorrentes preferencial para SE. A fácies LafMo corresponde a intercalações de lamitos e arenito fino de pouca espessura, com geometria ondulada (comprimento de onda de 1,2 $\mathrm{m}$ e amplitude de 0,18 $\mathrm{m}$ em média). Em contato erosivo com fácies acima, a 

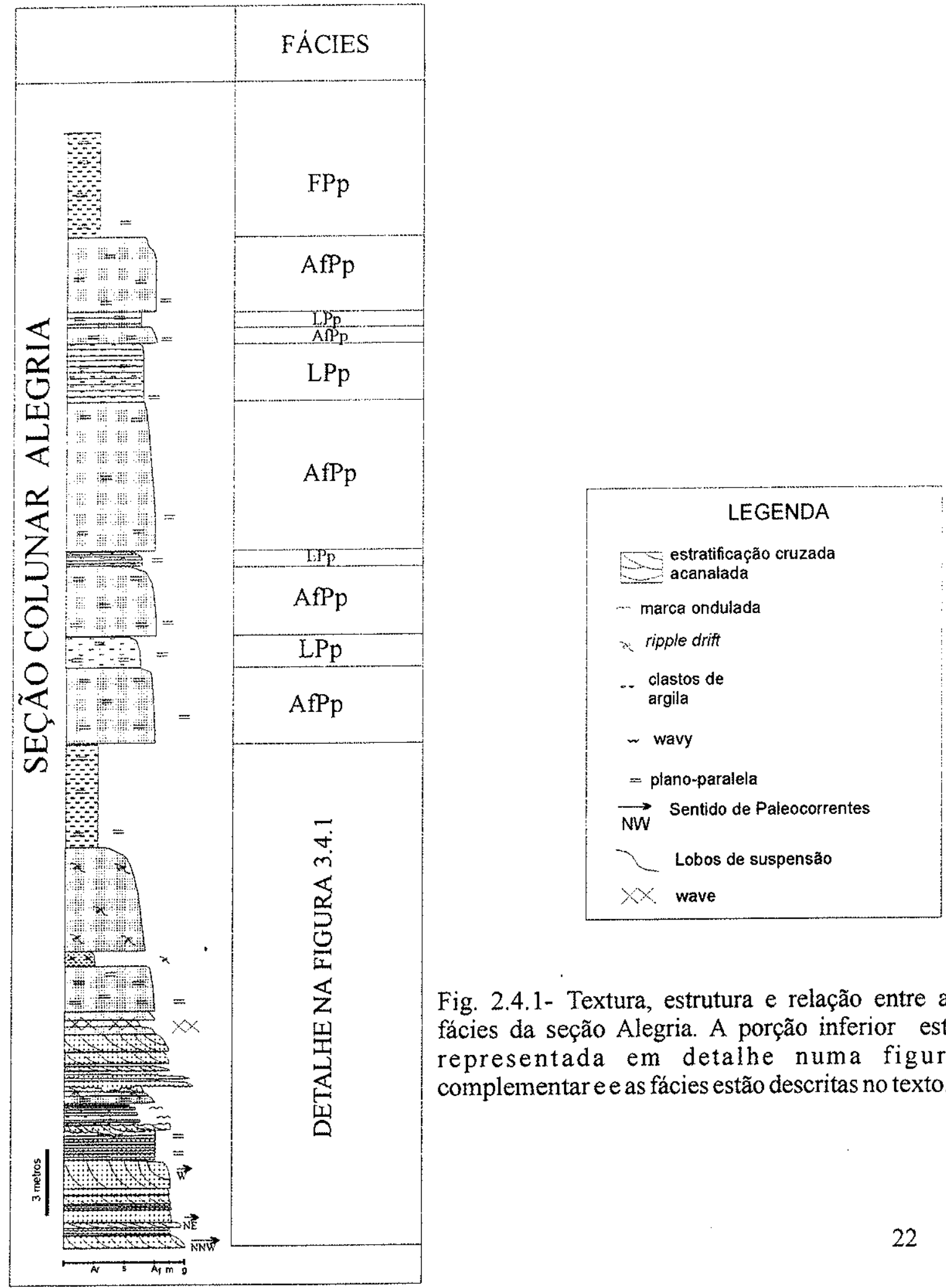

Fig. 2.4.1- Textura, estrutura e relação entre as fácies da seção Alegria. A porção inferior está representada em detalhe numa figura complementar e e as fácies estão descritas no texto. 


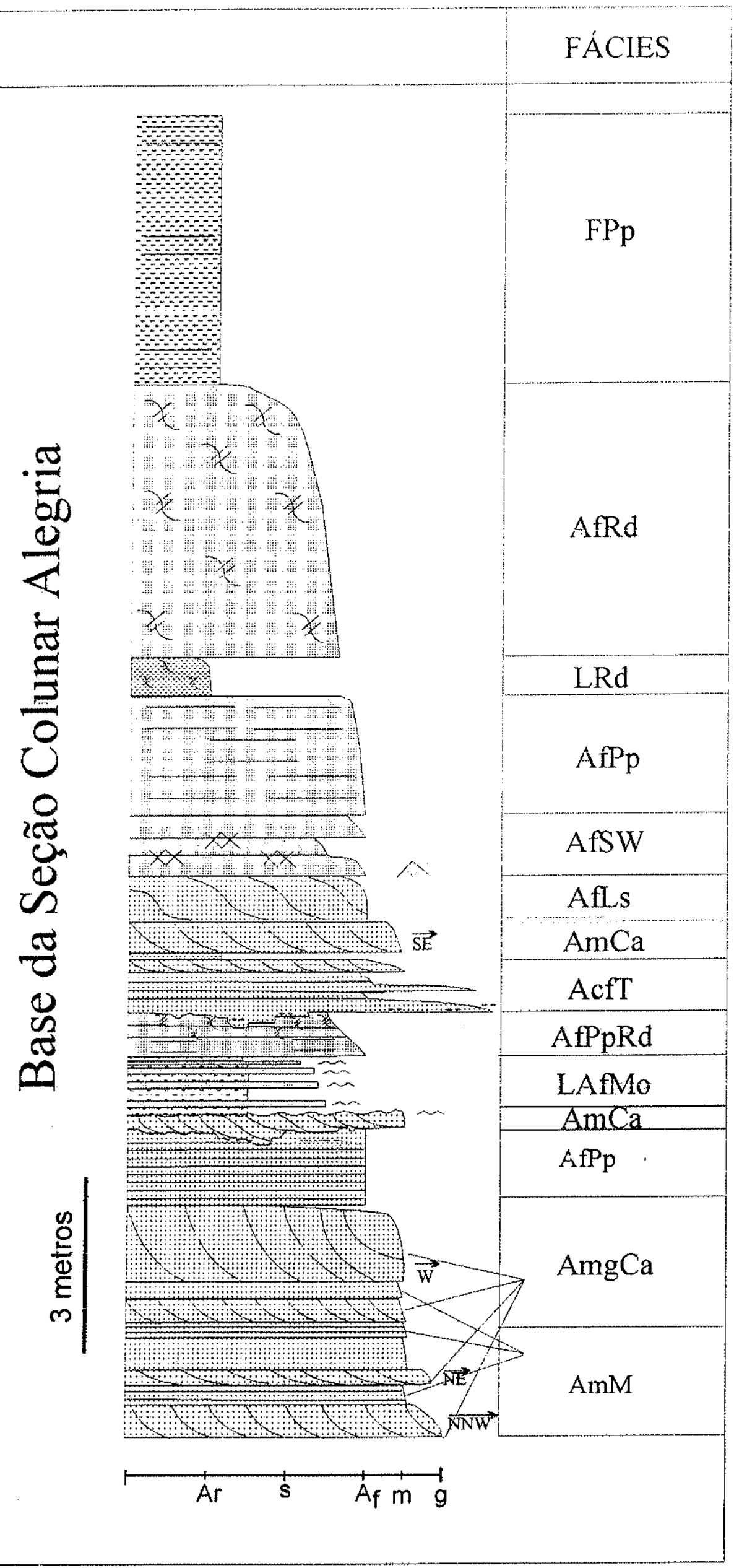

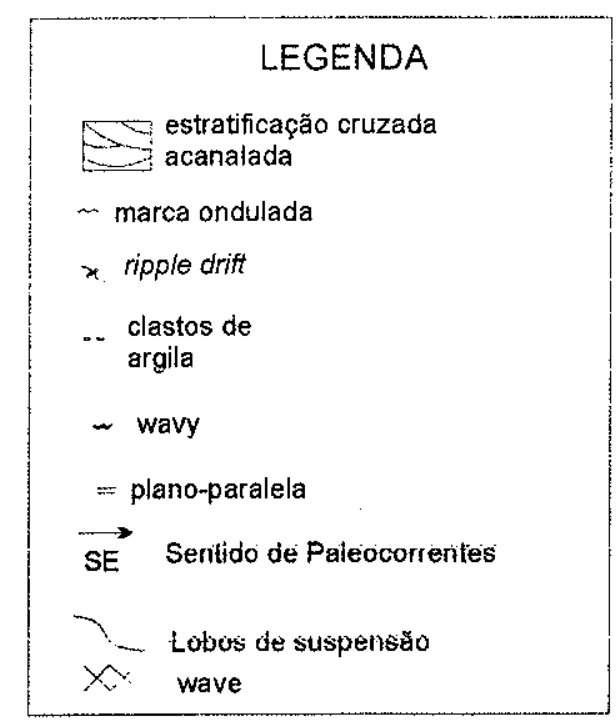

Fig. 3.4.1- Textura, estrutura e relação entre as fácies da porção inferior do seção Alegria. As fácies estão descritas no texto. 
fácies AfPpRd corresponde a arenito com granodecrescência ascendente, mostrando estratificação plano-paralela (?) na porção inferior e laminação cavalgante na porção superior. A fácies AcfT compreende arenito conglomerático, com clastos de argila achatados e fragmentos de siltito, apresenta brusca diminuição textural, passando para arenito fino/siltito, onde se ressaltam os truncamentos de onda de tempestade de pequeno porte. Com textura mais fina se encontram a fácies AfLs, cujas características principais são as estratificações clinoforma e afinamento textural, no limite superior da camada. A fácies AfSW encerra a tendência de afinamento para o topo, verificada desde a fácies AcFT e mostra a ação de ondas de tempestade com a presença de marca de onda de pequeno e médio porte $(<15 \mathrm{~cm})$. Representada por camadas tabulares com mais de dois metros de espessura, a fácies AfPp exibe homogeneamente arenito fino com estratificação plano-paralela. A fácies LRd é caracterizada por arenito muito fino, siltito e argilito depositados num contexto de baixa energia, na interface tração-suspensão. Nos depósitos acima verifica-se um aumento na energia disponível neste sistema e conseqüente aumento na fração areia fina, entretanto, ainda na interface tração-suspensão. Em contato normal ocorre a fácie FPp, uma camada de pelitos facilmente identificada em afloramentos próximos, os folhelhos ocorrem predominantemente com laminação plano-paralela mas encontram-se localmente laminação cavalgante. Acima, há alternância entre as fácies AfPp e FPp com uma tendência de aumento de espessura para o topo, até a porção mediana da seção. Após, verifica-se aumento sistemático da espessura da fácies de folhelho com laminação planoparalela e recorrência desta associação por cinco vezes, culminando com a presença de uma espessa camada de folhelho laminado.

A porção basal da seção foi interpretada como depósito fluvial afogado (fácies AmM, AmgCa, AfPpAmCa), coberto por depósitos de tempestade (fácies LafMo, AfPpRd, AcfT, AmCa e AfLs) e sistemas deltaico (fácies AfSW, AfPp, LRd, AfRd, FPp).

\section{Seção colunar Santa Rita}

Na seção colunar Santa Rita foram individualizados 10 fácies (Fig.4.4.1 e Fig. 5.4.1): AmMMo, LPp, LW, AfW, AmGda, AfW, LCWLC, LWyLPpLs, AmfCt, AfmCgQF. 

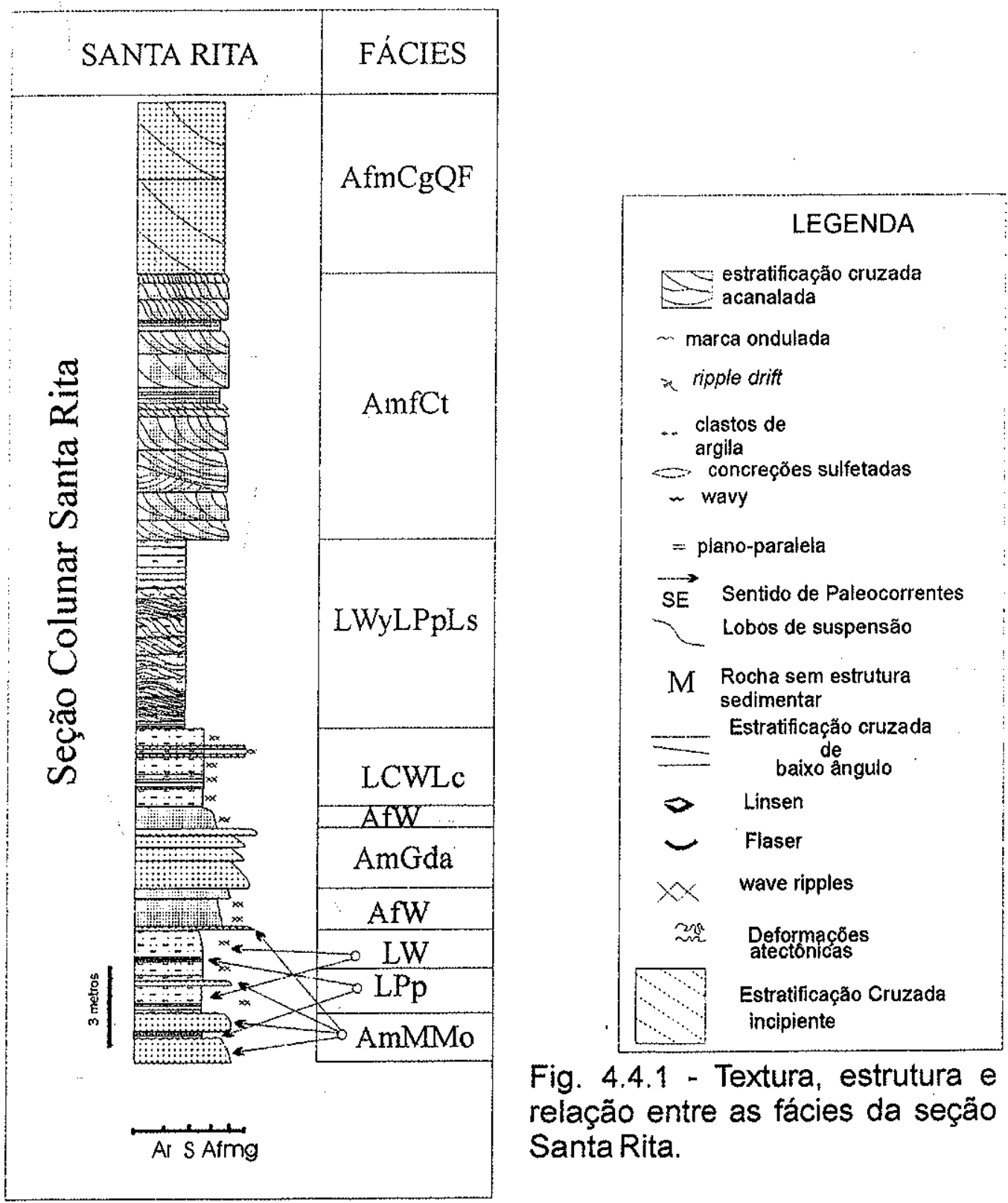

Fig. 4.4.1 - Textura, estrutura e relação entre as fácies da seção Santa Rita. 


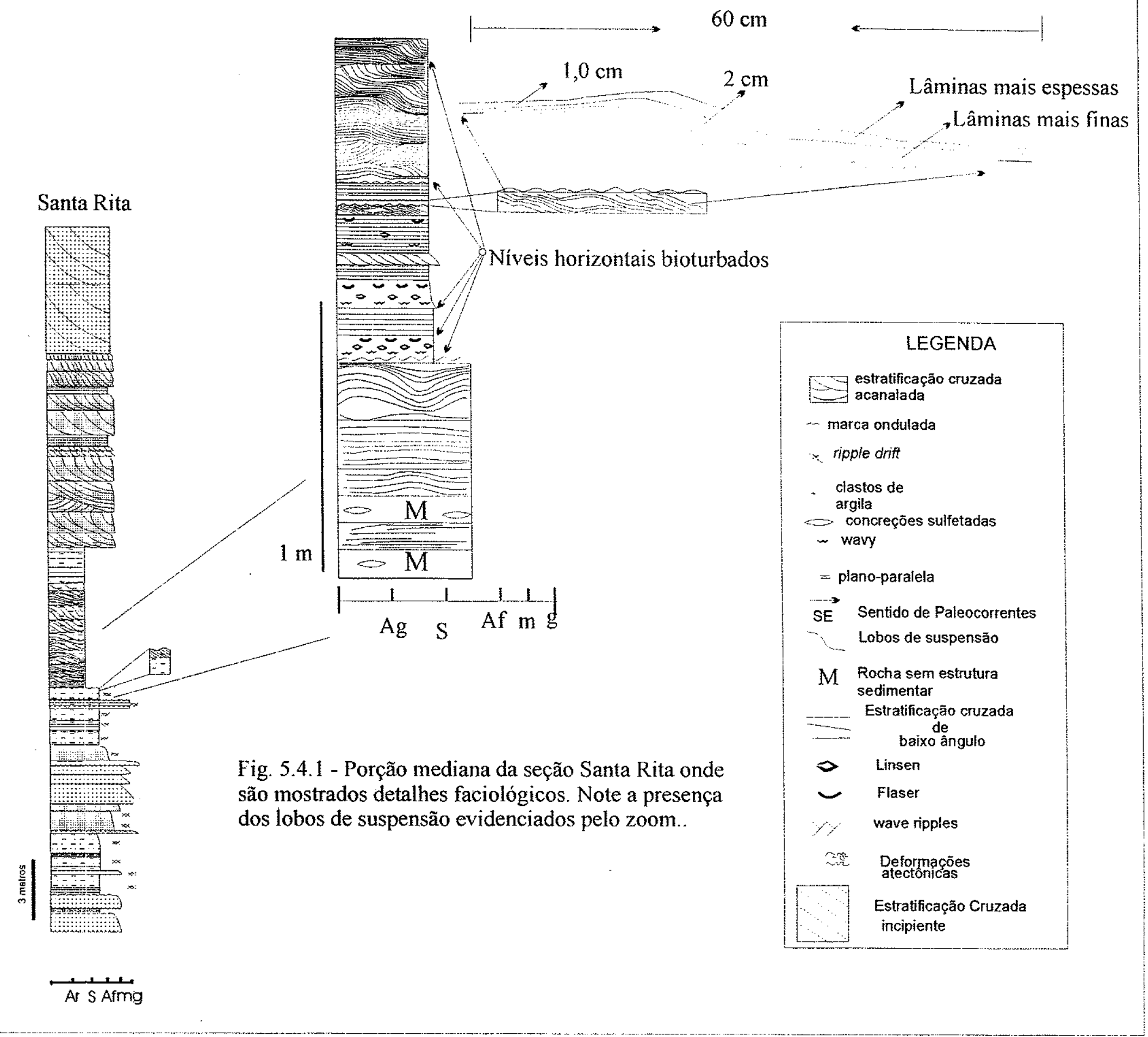


Na porção inferior ocorre arenito médio, maciço (AmMMo), com sutil granodecrescência ascendente e diminuição das espessuras das camadas para o topo, delimitados os estratos por marcas onduladas de cristas sinuosas. Estas camadas, de geometria tabular, afinam lateralmente. Lamito com laminação plano-paralela (LPp) ocorre intercalado com a fácies AmMMo, na base da seção colunar, apresenta espessura restrita mas boa continuidade lateral. A fácies lamito com marca de onda (LW) ocorre também intercalada com fácies AmMMo, predominando na porção superior da base da seção. Arenito fino com marca de onda (AfW), semelhante ao anterior, diferindo apenas na textura mais grossa. Arenito médio com granodecrescência ascendente (AmGda), geometria ligeiramente plano-convexa, afinando lateralmente até desaparecer. Lamito com lente de areia grossa/muito grossa ( $15 \mathrm{~cm}$ de comprimento, $2 \mathrm{~cm}$ de amplitude) com espessura de poucos centímetros, mostrando concreções sulfetadas (pirita, bornita?) disseminadas, exibindo marca de onda e lobos de suspensão (LCWLs). A fácies de lamito com estratificação ondulada, estratificação lenticular (veja o detalhe da seção colunar na Figura 5), plano-paralela com lobos de suspensão (LWyLPpLs) tem como característica marcante a separação de estratos em niveis horizontais bioturbados, com marcas onduladas (Fotos 1 e 2 - Estampa 1). Em contato brusco ocorre acima a fácies arenito médio a fino com cruzadas tangenciais na base. As estratificações mostram ângulo de mergulho variável, muitas vezes separadas por filmes de argila (bundlles e pares conjugados de argila), as estratificações indicam sentido de paleocorrentes preferencial para SE e subordinadamente para NW. Finalizando, encontram-se a fácies AfmCgFQ, correspondente a arenito fino a médio com estratificação de médio a grande porte, marcada por laminações por queda e fluxo de grãos.

As fácies inferiores AmMMo, Lpp parecem corresponder a depósitos fluviais afogados, enquanto as fácies $L w, L P p, A f W, A m G d a, L C W L c$ foram interpretadas como depósitos em plataforma retrabalhada por ondas de tempestade. A fácies LWyLPpLS sugere a presença de lobos de suspensão, com algum retrabalhamento por ação de marés. As fácies AmfCt e AfmCgQF correspondem, respectivamente, a canais de marés e dunas eólicas costeiras. 


\section{Seção colunar Serra da Cruz}

A seção levantada em escarpas nos arredores do município de São Francisco, MA, (Foto 1 e 2 - Estampa 2), representa descrições quase continuas (Figuras 6.4.1, 7.4.1, 8.4.1), perfazendo um pacote de aproximadamente $170 \mathrm{~m}$, para o qual foram caracterizadas 30 fácies.

$\mathrm{Na}$ seção colunar 1 e 2 (Figura 6.4.1) foram caracterizadas as fácies: $\mathbf{C C i}$ correspondente a um conglomerado, suportado por matriz arenosa grossa, com seixos de quartzo dispersos (segundo planos mal definidos), bem arredondados, alguns esféricos, com espessura de $10 \mathrm{~m}$ e geometria tabular. A fácies AgcCa corresponde a um afinamento textural da fácies anterior, caracterizada por arenito grosso a conglomerático, com seixo de argila marcando a estratificação cruzada acanalada de médio porte, níveis mais grossos ocorrem com espessura menor que $10 \mathrm{~cm}$. A fácies AmfMMo corresponde a arenito com textura média a grossa, sem estratificação visivel, marcada no topo por marcas onduladas, com comprimento de onda variando de 17 a $20 \mathrm{~cm}$ e amplitude de 2 a $2,5 \mathrm{~cm}$ com sentido preferencial do fluxo para NW. Arenito fino com estratificação cruzada acanalada ( $\mathrm{AfCa}$ ) encontra-se em contato aparentemente erosivo sobre a fácies AmfMMo e em contato brusco com a fácies acima, com sentido preferencial de paleocorrentes para NW. Esta fácies retrata o máximo de afinamento textural desde a porção basal da seção descrita. A fácies arenito fino a médio com estratificaçäo cruzada acanalada (AfmCa) é semelhante às anteriores diferindo pela textura mais grossa, também ocorre com geometria tabular, enquanto a fácies arenito médio com estratificação cruzadas acanalada (AmCa) ocorre intercalada por mais de $15 \mathrm{~m}$ com a fácies AfmCa, mostrando a flutuação da intensidade do regime de fluxo que condicionou a sedimentação. Já na porção 2 da seção a fácies CCi volta a ocorrer, desta feita com apenas dois metros de espessura. Acima, ocorrem intercalações entre as fácies AfmCa e arenito grosso com cruzadas acanaladas (AgCa), esta última com marcas onduladas no topo $(\lambda=11 \mathrm{~cm}$, $A=2 \mathrm{~cm}$ ), mostrando sentido de paleocorrente para SE. As fácies AfmCgQF e AfSPpLs representam, respectivamente: arenito fino a médio, com bimodalidade textural em lâminas individuais, exibindo estratificação cruzada de grande porte, laminação marcada por queda e fluxo de grãos, e arenito fino a siltito com estratificação plano-paralela (?), com alguma ondulação e lobos de suspensão. Arenito fino com estratificação cruzada acanalada (AfCa) e arenito médio com estratificação cruzada (AmCa) se intercalam em 

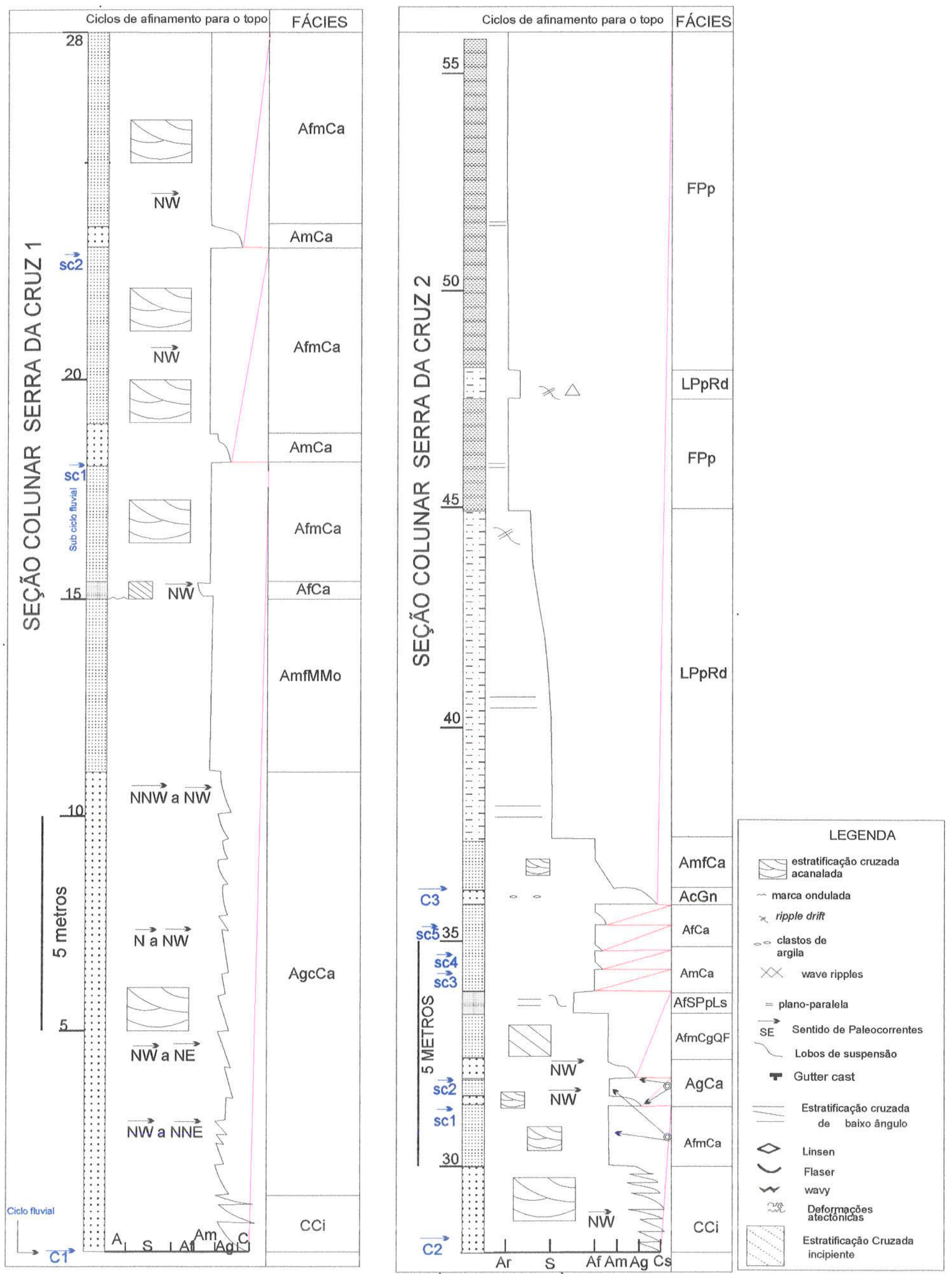

Fig. 6.4.1 - Fácies sedimentares das seções 1 e 2 da Serra da Cruz, note a distribuição dos estratos segundo ciclos de afinamento para o topo e a variação de espessura destes ciclos. As descrições e explicações estão no texto. 
estratos de pequena espessura $(<1 \mathrm{~m})$ até a presença de outra fácies de textura mais grossa AcGn, caracterizada por arenito conglomerático com gradação normal, portando seixos líticos, principalmente de siltito e argilito. A fácies arenito médio a fino é resultado de uma gradação normal da fácies anterior que afina bruscamente ( fácies LPpRd) para um siltito, com laminação plano-paralela e gradualmente para um argilito siltoso com laminação cavalgante na porção superior. Finalizando a seção, encontram-se uma camada de folhelho (>10 m), com laminação plano-paralela (fácies FPp) com uma intercalação de lamito com laminação plano-paralela e laminação cavalgante (fácies LPpRd). As porções 3 e 4 da seção colunar da Serra da Cruz estão representados na Figura 7.4.1. Na porção inferior da seção 3 encontram-se a fácies FPp, em continuação da seção colunar anterior. Acima, ocorre um arenito fino com estratificação plano-paralela (AfPp) constituído de camadas centimétricas, disposto em estratos tabulares de 20 a 50 $\mathrm{cm}$, perfazendo mais de $8 \mathrm{~m}$ de espessura. A fácies AfCaLs está representada por um corpo arenítico de textura fina, com estratificação cruzada acanalada de pequeno porte e lobos de suspensão na porção superior do corpo. Sua geometria é tabular, mas mostra um afinamento lateral, chegando a espessuras da ordem de $5 \mathrm{~cm}$. Esta fácies se intercala com a fácies SPp, caracterizada por camadas de siltito com estratificação plano-paralela com espessura aproximada de $8 \mathrm{~m}$. Separados por uma crosta laterítica, que também preenche fraturas, ocorre a fácies AmgEp caracterizada pela presença de arenito, com textura média a grossa, exibindo estratificação cruzada tipo espinha de peixe, com espessura inferior a um metro. Em contato brusco, encontram-se acima, a fácies AmfCt, cujas características principais são: a variação textural de areia média a fina, as estratificações cruzadas tangenciais, com variação nos ângulos de mergulho $\left(13^{\circ}\right.$ a $\left.18^{\circ}\right)$. No limite inferior de cada corpo observam-se diminuição granulométrica. A fácies AfB apresenta textura arenítica fina, completamente bioturbada, obliterando possiveis estruturas sedimentares primárias existentes. Na porção superior da seção colunar 3 ocorrem novamente as fácies AmfEp e AmCt. Na porção basal da seção colunar 4 encontram-se a fácies AfCaPp caracterizada por arenito fino, com estratificação cruzada acanalada de pequeno porte, marcada por clastos de argila (1 a $2 \mathrm{~cm}$ ), com estratificação plano-paralela na parte superior, disposto em estratos de geometria tabular. Há uma passagem gradual para a fácies LFWLRdT, caracterizada por areia fina/siltito na porção inferior, com abundantes estruturas tipo estratificação flaser e, subordinadamente, estratificação ondulada e estratificação lenticular, passando para argilito siltoso com 

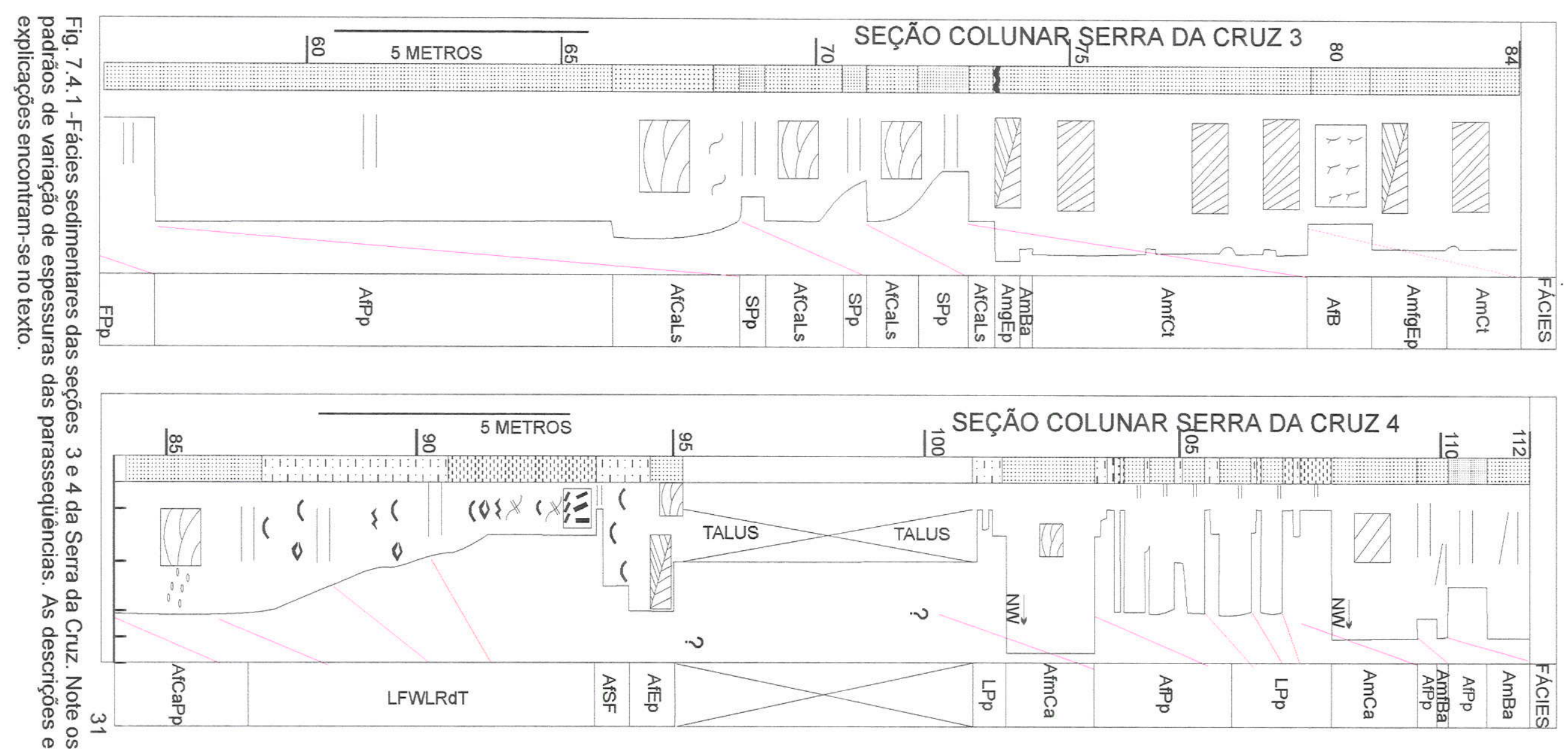
laminação cavalgante na porção superior, culminando com uma camada de tepees e lamito com estratificação plano-paralela. Acima, ocorrem as fácies: arenito fino a siltito com estratificação flaser (AfSF) e AFEp e após um intervalo de mais de 5 metros, com parte do afloramento coberto por depósito de tálus, ocorre a fácies lamito com laminação plano-paralela (LPp), com espessura reduzida. São encontrados mais de $5 \mathrm{~m}$ com intercalações de arenito fino com estratificação plano-paralela (AfPp) e lamito com planoparalela (LPp). Finalizando a seção colunar 4, encontram-se as fácies (AmCa) arenito médio com estratificação cruzada acanalada, e intercalações das fácies (AfPp) e (AmBa, AmfBA). Respectivamente, arenito fino com estratificação plano-paralela e arenito fino (e médio) com estratificação de baixo ângulo. As seções colunares 5 e 6 estão representados na Figura 8.4.1. Na base, ocorre a fácies LPp com espessura inferior a 0,5 m e acima um espesso pacote, caracterizado pela presença de arenito médio a fino, com estratificação cruzada de grande porte, tangencial na base, mostrando laminações por fluxo e queda de grãos (fácies AfmCgQF), formando uma escarpa abrupta com quase 40 m. A fácies FPpRdW é caracterizada pela presença de folhelho, com laminação planoparalela e cavalgante. Na porção inferior a textura é um pouca mais grossa e ocorrem marca de onda. Acima, intercalam-se conglomerado fino, com marcas onduladas (Cmo) e arenito fino com marca de onda, mostrando na porção superior gretas de contração. $A$ fácies FPp volta a ocorrer, seguida pela fácies arenito médio a grosso maciço (AmgM), sobreposto por intercalação de folhelho, com laminação plano-paralela com greta de contração (FPpG) e arenito fino com estratificação de baixo ângulo.

Estas seções colunares levantados permitem a criação de um quadro preliminar da distribuição dos tipos litológicos da Formação Piauí, em especial da porção inferior e média. Pode-se concluir, ainda preliminarmente, que predominam os depósitos siliciclásticos arenosos sobre as frações pelíticas na borda leste. Entretanto, a melhor visualização das variações litológicas e paleoambientais nos depósitos equivalentes às formações Piauí, Pedra de Fogo e Motuca só se faz possivel com a inclusão de dados de subsuperfície. Para tanto, foram selecionados alguns poços para elaboração de seções estratigráficas (Figura 9.4.1) denominadas de: seção estratigráfica Borda Leste, composta a partir dos poços 8, 9 e 10, além das seções colunares da Serra da Cruz e da Baixa Fria, que apresenta uma direção geral nordeste/sudeste; seção estratigráfica Norte - Sul, envolvendo os poços 1, 2, 3,4,6, 14 e 15; seção estratigráfica Leste - Oeste, levantada a partir dos poços 5, 4,7 e 8; seção estratigráfica Sul, compreendendo os 

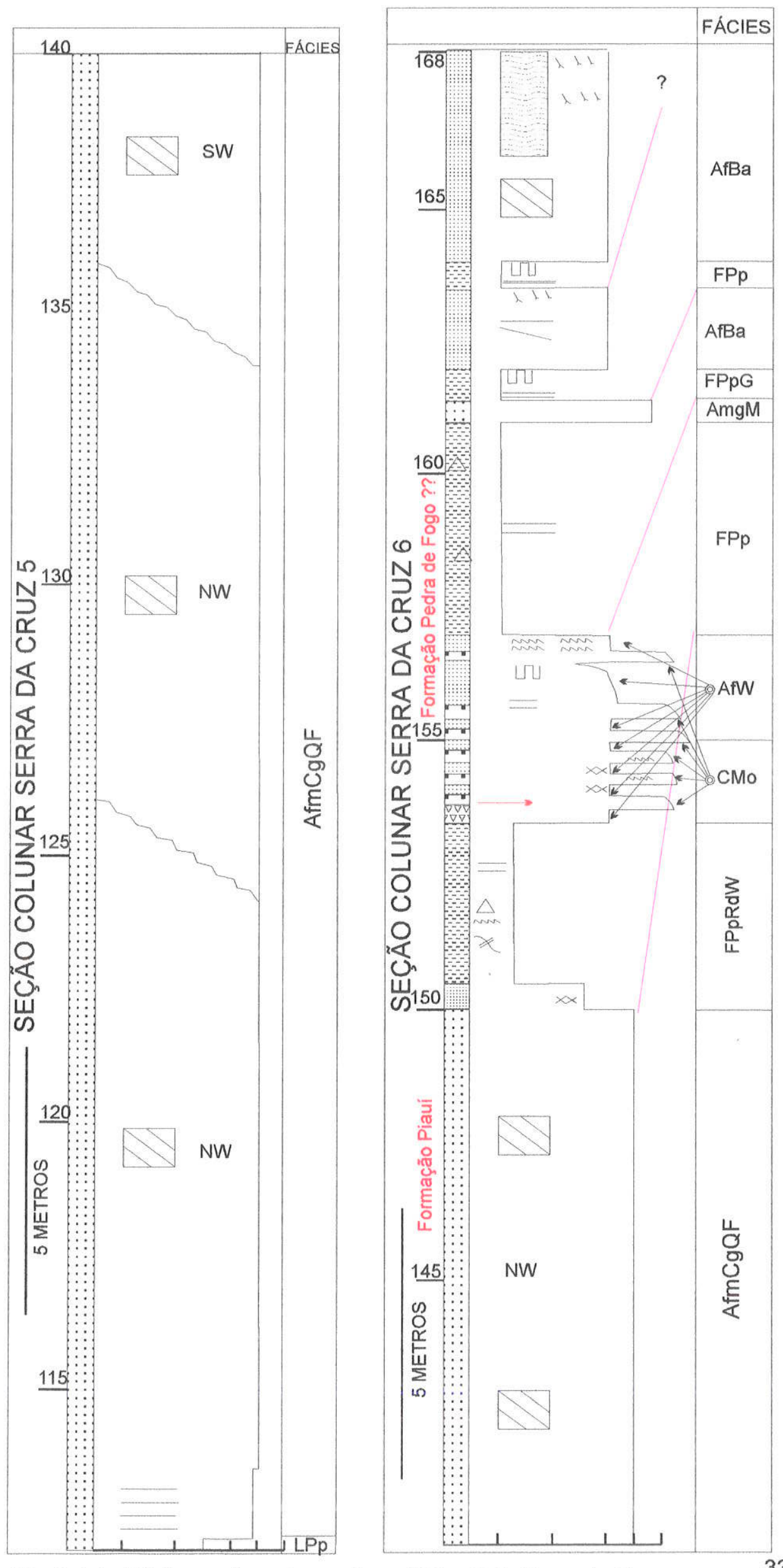

Fig. 8.4.1 - Fácies sedimentares do perfil 5 e 6 da Serra da Cruz, as 33 descrições e explicações encontram-se no texto. Ressalta-se o espesso pacote arenoso interpretado como depósito eólico. 


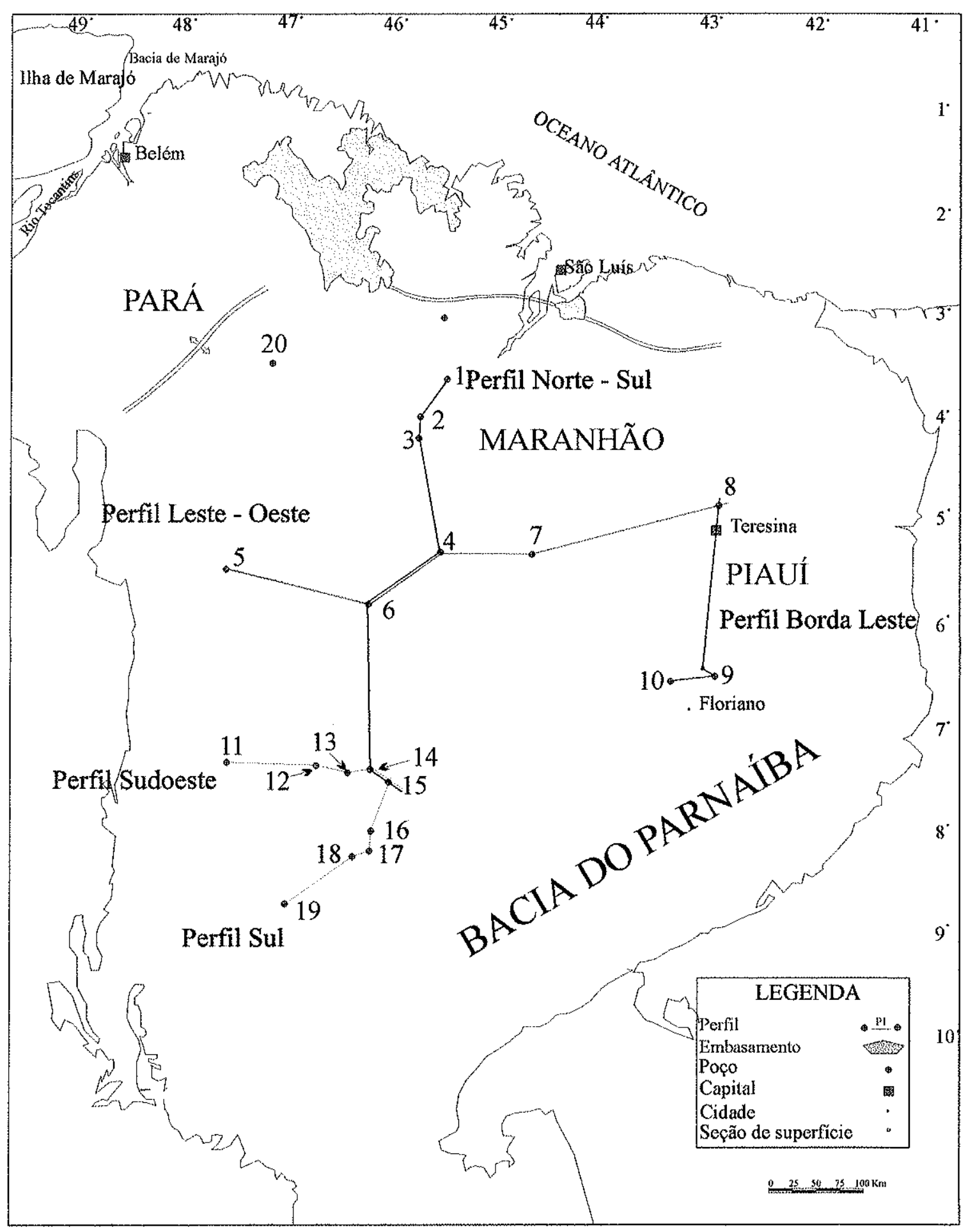

Fig.9.4.1 - Mapa de localização dos poços da Petrobrás na Bacia do Parnaíba, utilizados para elaborar as seções estratigráficas. 
poços 19, 18, 17 e 16; e seção estratigráfica Sudoeste com os poços 11, 12, 13, 14 e 15. A seção estratigráfica Borda Leste (Figura 5.7.1) destaca-se pela presença de corpos arenosos, com razoável espessura, na porção inferior da formação, logo acima do contato com a Formação Potí. Estes corpos tornam-se mais espessos entre a seção colunar do poço 9 e a seção colunar da Serra da Cruz, em São Francisco, MA, diminuindo de espessura para nordeste, quando cedem espaço para as rochas pelíticas. Na porção mediana da seção estratigráfica há um aumento significativo da presença de corpos pelíticos, como também de sudeste para nordeste. São encontrados na porção superior da seção corpos arenosos, que podem ser comparados ao Arenito Saráiva, que também ocorrem nas imediações de Teresina, PI. Os corpos arenosos estão presentes desde a borda sudeste, passando pela região central, até a borda nordeste. São percebidos tanto nas seções colunares de poços, testemunhos, como nas seções colunares levantados em afloramentos e também nas rodovias. Outro ponto relevante é a ausência de evaporitos e a restrita ocorrência de carbonatos na porção $N E$ da bacia. Apesar de ser considerada como uma bacia evaporítica, os depósitos equivalentes parecem restritos às regiões mais internas da Bacia do Parnaíba.

A distribuição dos tipos litológicos, como mostrado na seção colunar, sugere uma continentalização de nordeste para sudeste. Como também nas porções inferiores e superiores das seções, ficando a parte mediana com maior influência marinha. Esta relação não vale para as rochas do limite nordeste da bacia. Este assunto será abordado com mais profundidade em tópicos adiante. 


\section{2- Formação Pedra de Fogo}

Plummer et al. (1948) propuseram a denominação Formação Pedra de Fogo para as camadas ricas em chert $\mathrm{e}$ fósseis vegetais do gênero Psaronius que ocorrem no teito do Riacho de mesmo nome, entre Pastos Bons e Nova lorque, MA.

Aguiar (1971) reconheceu o caráter cíclico da formação observado por Barbosa \& Gomes (1957 apud Aguiar, 1971), na área do rio Tocantins, e caracterizou os ciclos como repetição de arenitos amarelados, siltitos, calcários oolíticos ou concrecionários e folhelhos esverdeado com restos vegetais e lentes de calcário. A formação é mais arenosa nas regiões sudeste e leste da Bacia do Parnaíba.

A Formação Pedra de Fogo foi dividida em três intervalos por Cruz et al. (1973): inferior, médio e superior. Na região compreendida entre os vales do Gurgueia e Uruçui Preto, no sul do Piauí, o intervalo inferior é representado por uma sucessão de folhelho e siltito cinza e preto com laminação plano-paralela, intercalados com camadas de arenitos finos esbranquiçados com estratificação flaser. A proporção em espessura é de 1: 1 entre arenitos e lamitos. Próximo ao topo da seção basal ocorre uma camada de $2 \mathrm{~m}$ de espessura de calcário creme, maciço, pouco argiloso, silicificado. Entre 38 e $46 \mathrm{~m}$ acima do contato com a Formação Piaui ocorrem arenitos com laminação síltica-argilosa e restos vegetais (impressão de folhas). O intervalo superior $(62 \mathrm{~m}$ ) é representado por arenitos creme, esbranquiçados, cinza esverdeados, finos maciços, ou com estratificação plano-paralela e cruzada. Ocorrem, subordinadamente, folhelhos e siltitos cinza esverdeado ou cinza. Na parte mais superior, ocorre um arenito cinza, parcialmente silicificado com fragmentos de oólitos. Para Cruz et al. (op. cit), este pacote da formação Pedra de Fogo não guarda muita semelhança com as litologias normalmente encontradas em subsuperfície. Faltam os diversos leitos de sílex que caracterizam esta unidade a a coloração típica em tons amarelados, roxos e róseos. O contato entre a Formação Piauí e a Formação Pedra de Fogo é concordante.

Faria Jr. \& Trunckenbrodt (1980) dividiram a Formação Pedra de Fogo em três membros. O Membro Silex Basal, de espessura média de $20 \mathrm{~m}$, amplamente distribuído na bacia, incluem siltitos a folhelhos, cinza, marron, arroxeados, intercalados com bancos dolomíticos com concreções silicosas. Na porção leste, o membro é mais terrígeno e compreende siltitos e arenitos finos, intercalados com camadas de sílex pouco espessas. $\mathrm{Na}$ região central e na borda oeste, ela é mais carbonática. O Membro Médio corresponde 
a arenitos e/ou siltitos, situados sotopostos às camadas ricas em sílex do Membro inferior, e que se estendem até as intercalações de folhelhos com silex contendo brechas intraformacionais, os quais representam o início do Membro Superior ou Membro Trisidela. Melo \& Prade (1968 apud Faria Jr. \& Trunckenbrodt, 1980) descrevem, no riacho Pedra de Fogo, um pacote de $44 \mathrm{~m}$ de arenitos, denominados Custódio, sotopostos ao nivel de sílica basal. Através de correlações de perfis estratigráficos este autores perceberam uma diminuição na espessura do arenito Custódio para sul, chegando até a siltitos intercalados com folhelhos e delgadas camadas de arenito na região de BalsasMA. O Membro Superior, Trisidela, possui espessura média de 40m, e ocorre principalmente nas regiões central e oeste da bacia. Sua seção típica situa-se na região de Balsas sendo representada por bancos dolomíticos, cinza, intercalados com siltitos, folhelhos carbonáticos e/ou margas, esverdeados. Ocorrem também, concreções, nódulos e niveis de silex. Para oeste o membro torna-se mais espesso. Nas proximidades do topo ocorrem fragmentos fósseis, incluindo troncos vegetais. Faria Jr. \& Trunckenbrodt (op. cit.) consideram que os litótipos da Formação Pedra de Fogo foram depositados em ambiente marinho, restrito, raso, tipo epicontinental, parcialmente transicional.

Coimbra (1983), com base em dados de petrografia sedimentar e estruturas sedimentares, admite a influência de marés e águas calmas como ambiente deposicional das rochas siliciclásticas, que deveu-se à calma tectônica que imperava e áreas fontes arrasadas. Dados isotópicos de $\delta \mathrm{C}^{13}$ também corroboram a interpretação de deposição transicional, de planície de maré e lagunar, para esta formação. Coimbra (op. cit.) conclui que a Formação Pedra de Fogo é constituida de arenitos síticos argilosos, de origem continental, flúvio-lacustre, que ocorrem nas porções sudeste, sul e leste da bacia; siltitos, dolomitos, margas, sílex e arenitos depositados em planície de maré, sob condições de alta salinidade, e arenitos de origem eólica. Quanto à origem do importante processo de silicificação, este autor considera que seja este em parte primário, parte sindiagenético e também com contribuição epigenética (sílex metassomático). Coimbra (op. cit.) admite um processo de dolomitização precoce (sindiagenético) para as rochas carbonáticas.

Apesar da evidência de clima árido ou semi-árido na Bacia do Parnaiba, a partir do Pensilvaniano, a abundância de troncos vegetais encontrados em alguns niveis da Formação Pedra de Fogo como, por exemplo, os que ocorrem in situ na região de Teresina-PI (Lima Filho \& Caldas, 1988), poderiam fazer supor um arrefecimento no clima durante parte do Permiano. Entretanto, uma análise mais refinada realizada por Caldas et 
al. (1989), após estudo sistemático de um novo gênero vegetal (Teresinoxilon euzebiol), mostram que este possui adaptação a condições de aridez. Os troncos referidos às Cycadoxyleae têm sido encontrados em bacias paleozóicas do hemisfério norte, desde o Carbonifero até o Permiano.

Mapeamentos realizados por Lima Filho et al.,(1995) e Ribeiro \& Melo (1996) na porção NE da bacia, que incluíram a região de contato entre as formações Piauí e Pedra de Fogo mostram, em superfície, a delimitação entre estas duas unidades litoestratigráficas, marcada comumente por níveis silicificados, sotopostos à camadas arenosas (interpretadas como de origem eólica) que pertencem à Formação Piauí. Estes pesquisadores interpretaram na região os sistemas deposicionais deltaico e de planície de marés para a Formação Pedra de Fogo. Este último parece ser o mais freqüente. $\mathrm{Na}$ Serra das Araras, entre Floriano e Amarante, $\mathrm{Pl}$, é também evidente o contato entre estas formaçōes, num contexto semelhante ao descrito anteriormente. Algumas escarpas com cotas significativas foram descritas mas o produto apresentou resultados insatisfatório. Entretanto, de uma forma generalizada, pode-se afirmar que na Formação Pedra de Fogo há uma contribuição pelítica muito maior em relação a Formação Piauí, principalmente, no que tange a sua base.

É apresentado uma seção estratigráfica levantado na BR-316, entre as cidades de Altos e Teresina, $\mathrm{Pl}$ a $2,5 \mathrm{Km}$ da estrada de ferro, já no município de Altos, denominado de Seção da BR - 316. Nesta seção não são encontrados os níveis silicificados que tanto dificultam a identificação das fácies sedimentares e, por este motivo é apresentada em escala de detalhes (Figura 1.4.4). Foram identificadas 8 fácies que serão descritas a seguir: a fácies inferior (LPp) é caracterizada pela repetição de camadas de lamito, exibindo laminação plano-paralela, com intercalações de arenito fino, que ocorrem sob forma lenticular ; a fácies ( $L W y L W$ ) lamito com geometria ondulada, mostra niveis onde predominam estratificação ondulada (wavy bedding) exibindo uma textura mais grossa, intercalados com niveis mais finos onde predominam estratificação lenticular (linsen) e laminação plano-paralela levemente ondulada. Na porção superior é visivel a presença de truncamentos por ondas de tempestade de pequeno porte (wave ripple), o topo da camada é marcado por uma superfície com marcas onduladas. A fácies SPp é uma variação textural mais grossa da fácies $L P p$ e ocorre restritamente, com estratificação plano-paralela. Arenito médio a fino siltoso (AmfSW), retrabalhado por ondas de 
SEÇÃO COLUNAR BR- 316

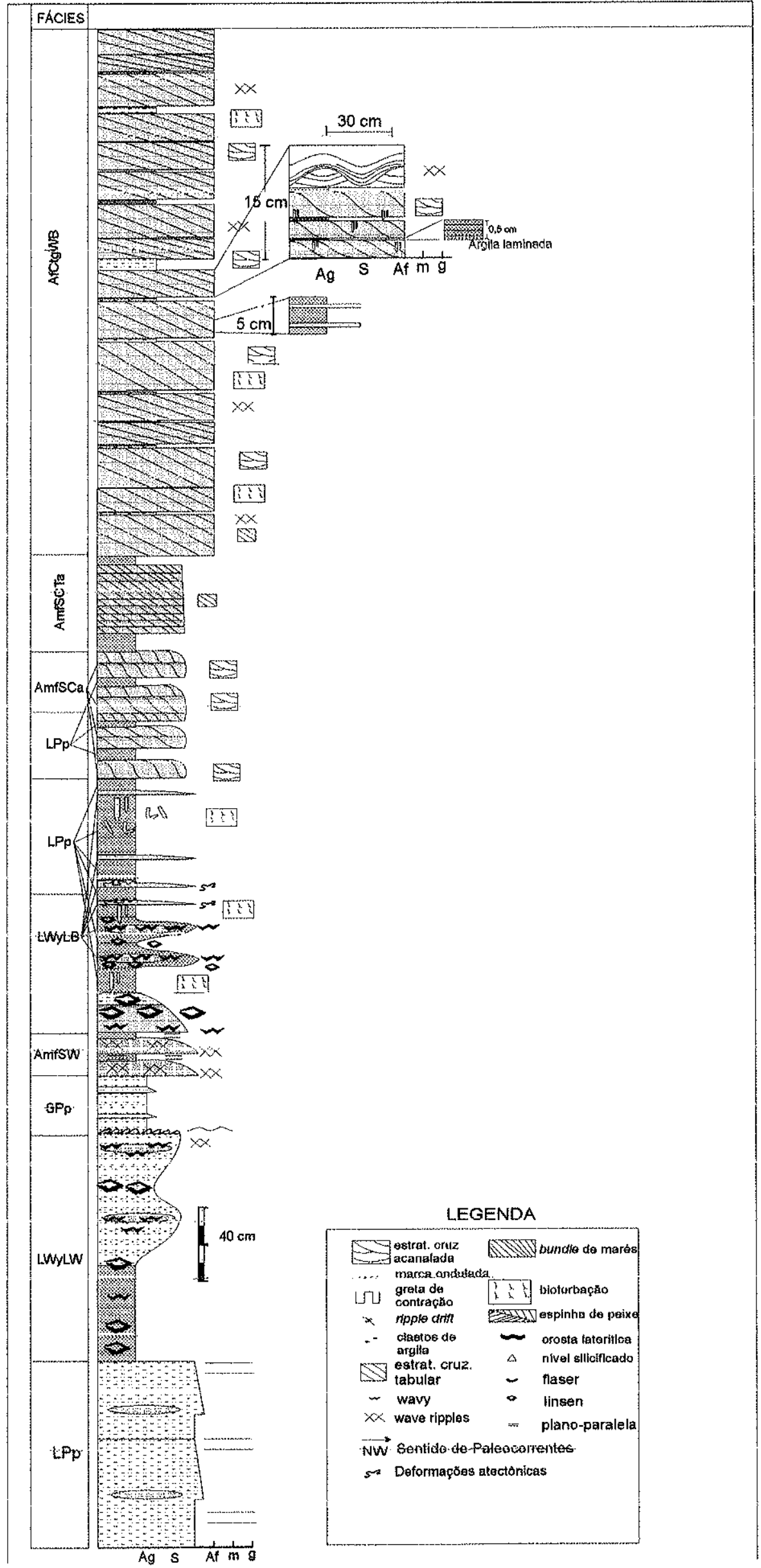

Fig. 1.4.2 - Seçảo colunar levantada na porçăo inferior da Formação Pedra de Fogo, na BR- 316 entre Altos e Teresina, PI. Näo foram encontrados afloramentos com grande expressäo topográfica, na maioria das vezes ocorrem rochas peliticas ou arenosas fina intensamente silicificadas. 
tempestade de pequeno porte, ocorre intercalado com camadas centimétricas de argilito laminado. A fácies LWyLB é caracterizada pela presença de estratificação ondulada e estratificação lenticular, marcando as porções mais grossas. Mostra afinamento para o topo e ocorre intercalada com a fácies LPp, que mostra-se mais espessa para cima, com abundante bioturbaçäo. Encontram-se também estruturas em chama e pseudo-nódulos. Verificam-se a intercalação entre as fácies arenito muito fino, siltoso com estratificação cruzada acanalada, que mostra afinamento textural em cada camada (AmfSCa), e a fácies LPp. A fácies arenito médio a fino, siltoso, com estratificação cruzada tabular (AmfSCta) ocorre intercalada com a fácies LPp. Finalizando; encontram-se a fácies arenito fino com estratificação cruzada tangencial de grande porte, com retrabalhamento por ondas de tempestade, mostrando abundantes níveis de bioturbados (AfCtgWB), cujos estratos estão separados por filmes de argilito. Nesta seção há uma clara ação de marés e de ondas de tempestade.

\section{3- Formação Motuca}

Plummer et al. (1948) denominaram de Formação Motuca um pacote bem exposto, na fazenda de mesmo nome, de folhelhos com intercalações de calcário e anidrita, que recobrem a Formação Pedra de Fogo, entre São Domingos a Benedito Leite no Maranhão. Consideram como de idade Triássico.

Mesner \& Wooldridge (1964) definiram a Formação Motuca como uma alternância de folhelhos e arenitos vermelhos; com intercalações de dolomitos e calcários. Reconhecem a carência de informações paleontológicas para caracterizar a idade desta formação. Entretanto, com base na presença de gastrópodes Pleurotomaria $\mathrm{sp}$ e de alguns peixes, consideraram a idade como neopermiana. Estes autores interpretaram o ambiente deposicional como continental (eólico e fluvial) e marinho/evaporítico, a partir de um mar residual. O clima foi mais árido, durante o tempo de deposição da Formação Motuca, do que durante a deposição das rochas da Formação Pedra de Fogo.

Aguiar (1971) divide a Formação Motuca em três membros: o inferior arenoso; o médio; com predominância de folhelho; calcário e anidrita e o superior, também arenoso:

Faria Jr. (1984) propõe um modelo deposicional de paleodeserto para o PermoTriássico da Bacia do Parnaíba, envolvendo as formações Motuca, Pastos Bons e 
Sambaiba, representando respectivamente, red beds associadas com sabkha continental e wadis, sistemas de leques aluviais e campos de dunas.

A Formação Motuca é constituida por arenitos silticos argilosos e siltitos também argilosos (red beds), além de calcários, dolomitas e gipsitas, mais freqüentes nas porções basais no setor oeste da bacia. O ambiente deposicional das rochas siliciclásticas é considerado continental, flúvio lacustre, enquanto que a sedimentação química estaria associada a mares residuais (Coimbra, 1983).

\section{Seção Colunar Ponta da Serra}

A seção colunar foi levantada no município de Sambaíba, $M A$, em frente a fazenda Ponta da Serra, em escarpas de testemunhos residuais. Representa apenas uma pequena parte da seção, cuja espessura completa envolve mais de $250 \mathrm{~m}$ da porção superior da Formação Motuca e toda Formação Sambaíba. Neste local foi proposto a seção tipo da Formação Sambaíba. Foram individualizadas 9 fácies as quais serão sucintamente descritas e apresentadas em seção colunar (Fig. 1.4.5). São as fácies: arenito fino a médio com estratificação cruzada tangencial na base (AfmCt), de médio porte, marcada por variações granulométricas dos grãos, onde se verificam camadas com predominância de areia média intercaladas com camadas com areia fina, ambas variando de 3 a $8 \mathrm{~mm}$ de espessura. A fração areia média apresenta-se melhor arredondada e esférica, é notável a seleção dentro de uma mesma lâmina/camada com a segregação nestas duas frações. Verifica-se a ação de intenso tectonismo. A fácies AfBa foi caracterizada a partir de arenito fino, com estratificação de baixo ângulo (planoparalela??). Em algumas situações parece representar porções mals distais de barras. Uma das fácies mais freqüentes nesta seção (AfmCa) é caracteriza-se pela presença de arenito de textura fina a média, com estratificação cruzada acanalada, com sentido de paleocorrentes indicando SE e NW como mais persistente. Entretanto, o intenso tectonismo deve ter obliterado significativamente o mergulho destas camadas. A fácies AfmfBa é apenas uma variação textural da fácies AfBa, anteriormente descrita. Já a fácies lamito vermelho com laminação plano-paralela (LPp) ocorre geralmente associada a fácies AfmCa e não possui espessura significativa. Ocorrendo como uma variação da fácies AfBa o arenito médio a muito fino, mostra ainda laminação aparente plano-paralela, bioturbado com perfurações verticalizadas, cilíndricas (AmmfPpB). Em alguns niveis 


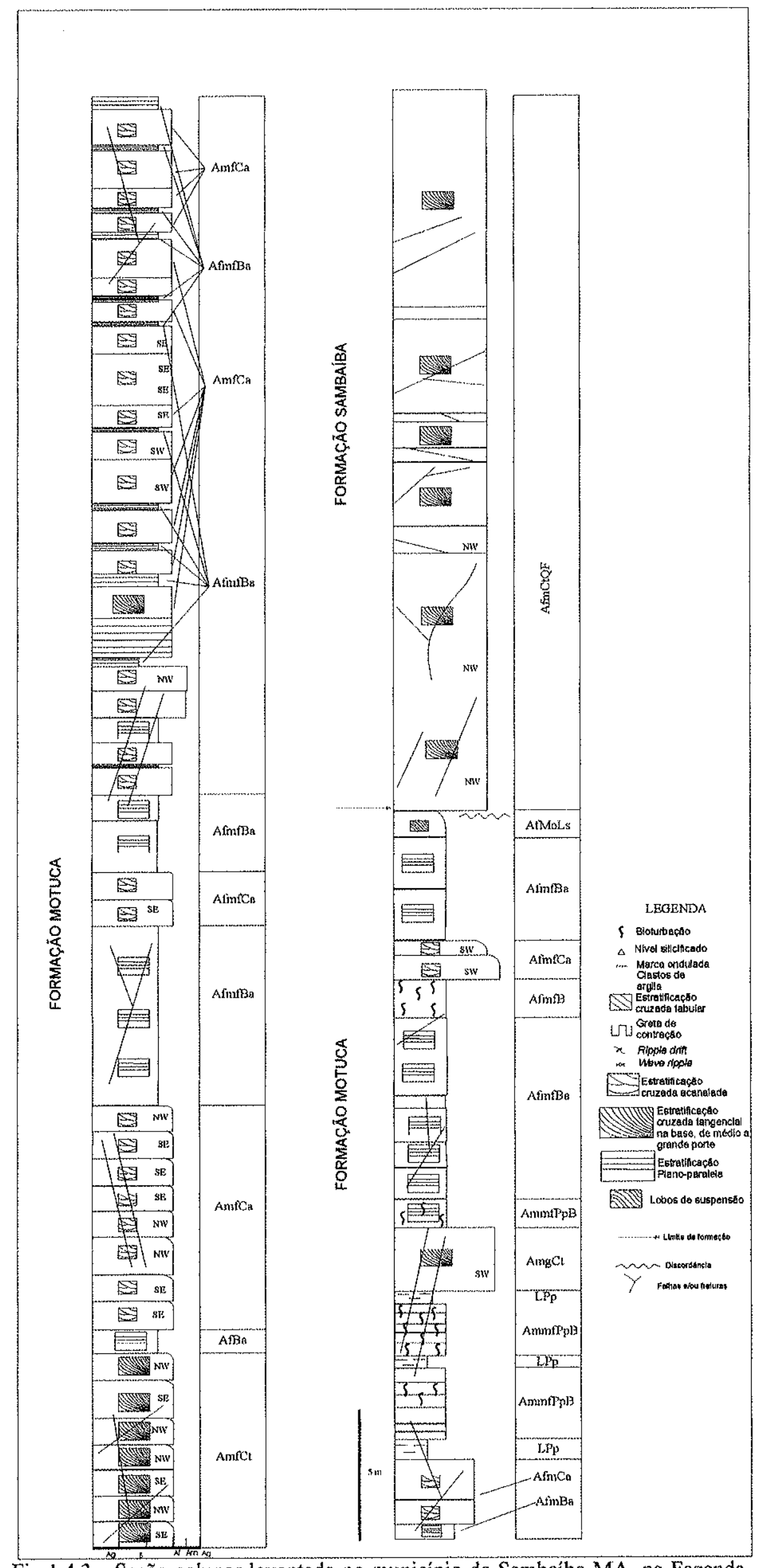

Fig. 1.4.3 - Seção colunar levantada no município de Sambaíba-MA, na Fazenda Ponta de Serra, onde ocorrem boas exposições das formações Motuca e Sambaíba. Neste local, foi convencionado a seção tipo da Formação Sambaíba. As rochas da Formação Motuca são representadas por arenitos, siltitos e lamitos. As fácies estão descritas no texto. 
oblitera completamente as estruturas sedimentares originais e por mais de $5 \mathrm{~m}$ esta fácies se intercala com a fácies $\mathrm{LPp}$. A fácies arenito médio a grosso, com estratificação cruzada de médio porte, tangencial na base (AmgCt), exibe camadas com espessura inferior a $1 \mathrm{~cm}$, com excelente seleção dos grãos e raras perfurações (bioturbações), apresenta também pequenas deformações (dobras). Arenito fino a muito fino com cruzadas acanaladas (AfmfCa) de pequeno porte é uma variação da fácies AfmCa e ocorre restrita a porção superior da seção. $A$ fácies arenito fino com marcas onduladas e lobos de suspensão (AfMoLs) ocorre em contato com a fácies (AfmCtQF) e caracteriza a passagem da Formação Motuca para a Formação Sambaíba.

\section{4 - Seções Estratigráficas}

Serão apresentadas as seções estratigráficas elaboradas exclusivamente com dados de subsuperfície, desta feita envolvendo conjuntamente as formações Piauí, Pedra de Fogo e Motuca.

\section{Seção estratigráfica Norte-Sul}

Elaborado a partir dos perfis compostos dos poços 1, 2, 3, 4, 6, 14 e 15 (Vide Figura 9.4.1), com direção aproximada norte-sul, esta seção estratigráfica (Fig. 1.4.6) secciona o centro atual da bacia por aproximadamente $500 \mathrm{~km}$, abrangendo todas as formações em estudo. A exemplo da redefinição dos contatos, em subsuperfície, entre as formações Piauí e Pedra de Fogo, proposto por Lima Filho (1991) e adotado por autores subseqüentes (p.e. Goes et al., 1990). É aqui também proposto o uso de uma camada de anidrita, de grande extensão lateral e de razoável espessura, para redefinir o limite em subsuperfície entre as formações Pedra de Fogo e Motuca. São apresentados os contatos, como utilizados pela Petrobrás (em vermelho) e a nova proposta (em azul), como mostram as Figura 1.4.6 e 3.4.6. No poço 1 não se encontram registros das formações Pedra de Fogo e Motuca; no poços 14 a perfuração foi iniciada na porção inferior da Formação Motuca e no poço 15 na Formação Pedra de Fogo (Fig. 1.4.6). Na base da Formação Piauí evidenciam-se a presença de corpos areníticos de considerável espessura, desde o poço 15 até $\circ$ poço 4 , que correspondem a mais de 60 


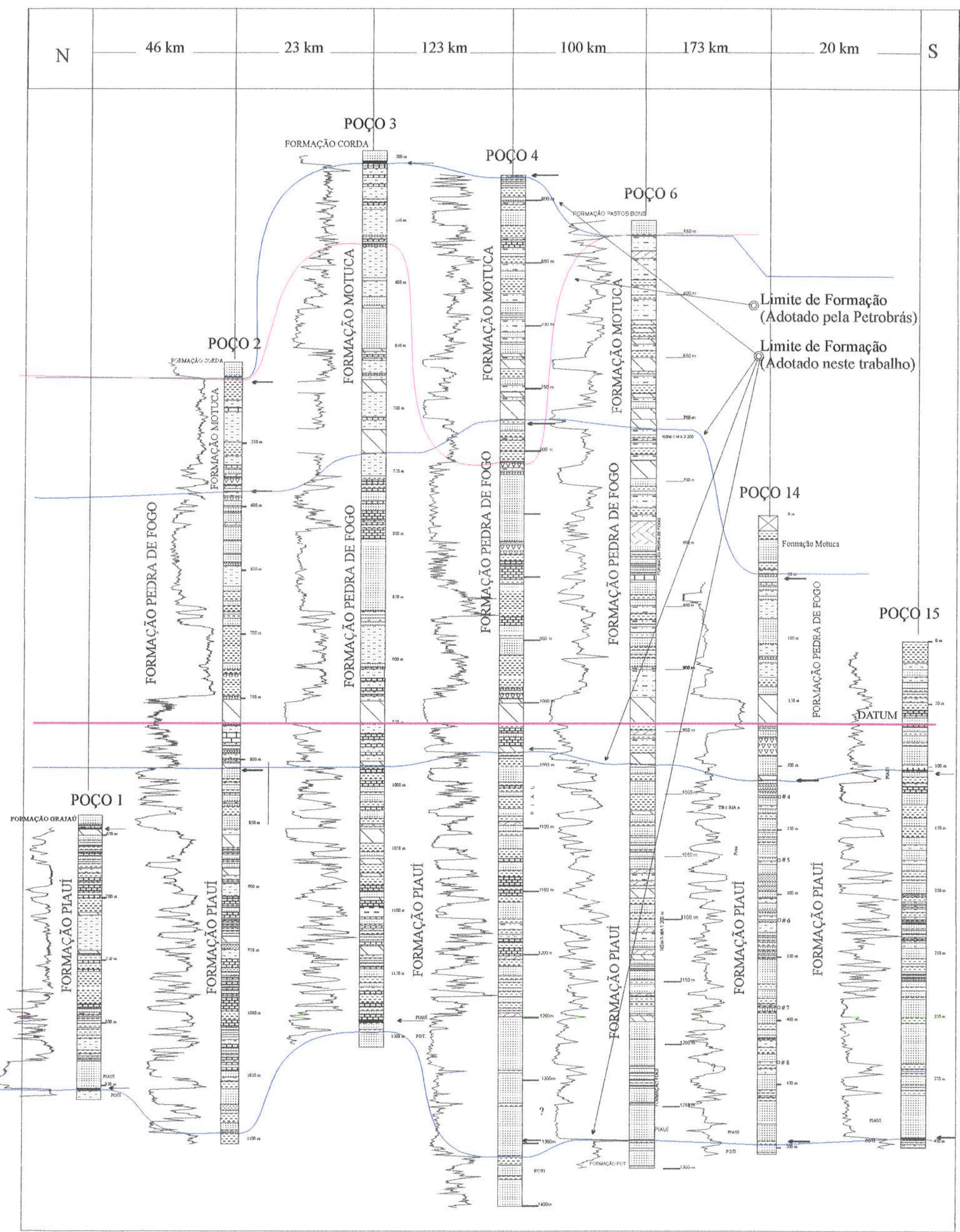


$\%$ do comprimento total da seção. No poço 3 o corpo arenoso praticamente desaparece, voltando a ocorrer de forma modesta no poço $2 \mathrm{e}$, com sutil aumento de espessura, no poço 1. Este último, situado mais próximo do limite da Bacia do Amazonas. O poço 15 , mais a sul, apresenta características diferenciadas dos demais. Podem ser ressaltadas a ausência completa de evaporitos e a pequena ocorrência de carbonatos, restrita a porção superior da formação. $O$ poço 14 , situado a apenas $20 \mathrm{~km}$ do anterior, apresenta apenas uma camada de evaporito, utilizada como referência para determinar o contato entre as formações Piauí e Pedra de Fogo. A partir do poço 6 (distando $173 \mathrm{~km}$ do poço 14), o contexto de bacia evaporítica é notório, com a presença significativa de depósitos evaporíticos ou carbonáticos. Sua ocorrência máxima se verifica nos poços 6 e 3 , situados próximos a prováveis depocentros da bacia. Ressalta-se, também, a relativa abundância de depósitos carbonáticos nos poços 2 e 3 (separados por apenas $23 \mathrm{~km}$ ). Esta distribuição litológica mostra a maior influência marinha em direção ao norte da bacia (já citado por pesquisadores anteriores) e a grande área de abrangência da bacia evaporitica, envolvendo mais de $95 \%$ do total da seção.

$\mathrm{Na}$ base da Formação Pedra de Fogo há predominância dos depósitos evaporíticos. Um destes níveis, que apresenta espessura de até $20 \mathrm{~m}$ de anidrita, foi utilizado como datum. Os evaporitos voltam a ocorrer na porção superior da formação apenas no poço 6 , um dos poços que mais apresentam corpos evaporíticos, situado no atual centro da bacia. A Formação Pedra de Fogo é relativamente mais pelítica que a Formação Piauí e apresenta menor número de intercalações arenosas, mostrando corpos arenosos concentrados, principalmente nas porções superiores. Percebe-se também um aumento da fração pelítica de sul para norte, semelhante ao que acontece na Formação Piauí.

A Formação Motuca é praticamente uma repetição continuada da Formação Pedra de Fogo, na sua base ocorrem concentrações de evaporitos e há presença significativa de rochas pelíticas. Entretanto, difere pela ausência de corpos arenosos de grande espessura.

\section{Seção Estratigráfica Sul}

Esta seção (Fig. 2.4.6) corresponde a continuação da seção estratigráfica norte-sul, 
SEÇÃO ESTRATIGRÁFICA SUL

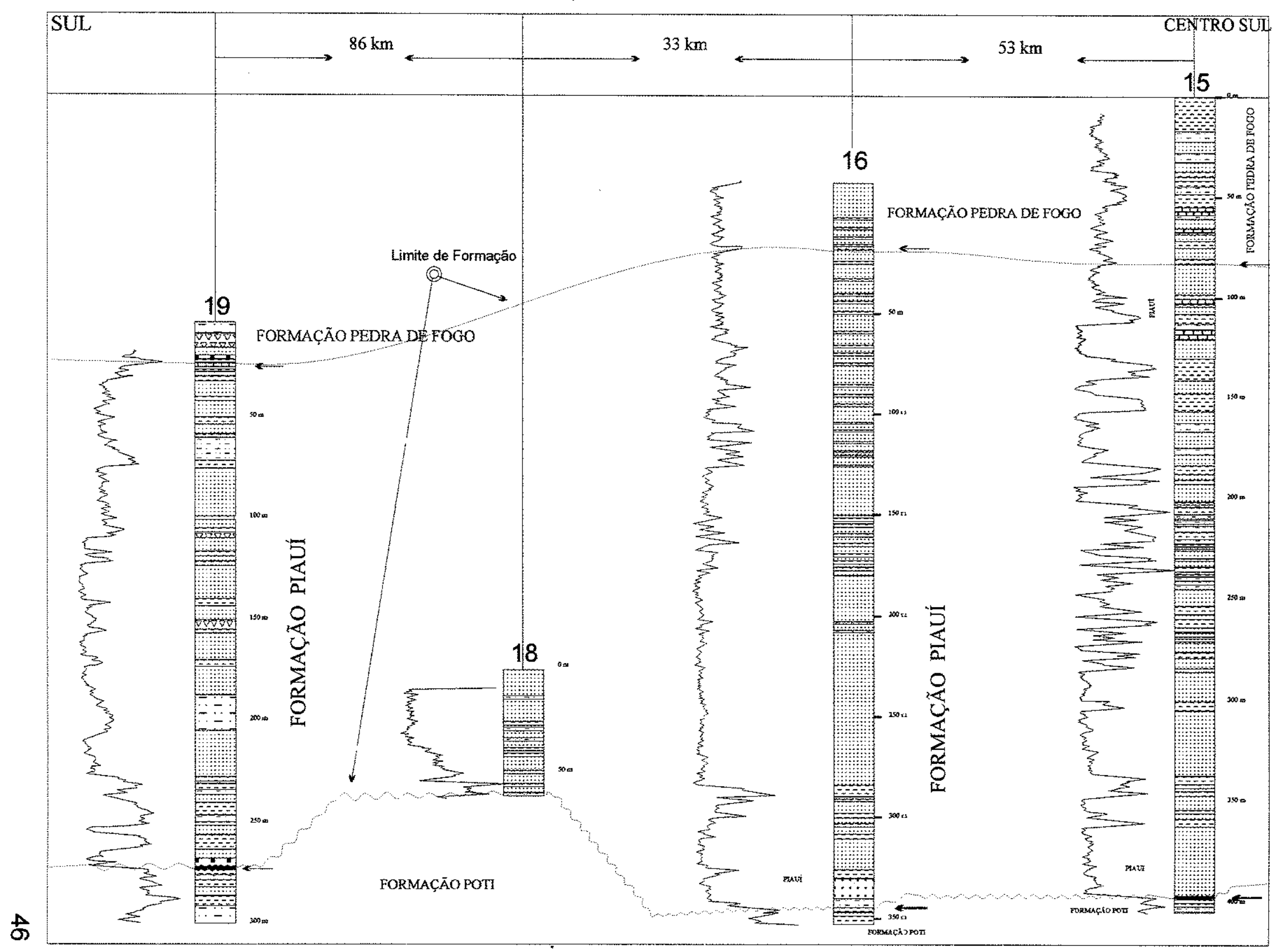

Fig. 2.4.4 - Corresponde a continuação da seção norte - sul e mostra a predominância de sedimentos arenosos sobre os pelíticos e carbonáticos, como também a ausência de evaporitos nesta porção da bacia. 
construído com base nos perfis compostos dos poços 19, 18, 16 e 15 (Fig. 9.4.1). Envolve apenas litologias da Formação Piaui e pequena porção da base da Formação Pedra de Fogo. Seguindo a tendência geral, há predominância de rochas arenosas, principalmente nos poços 15 e 16. No poço 16 verifica-se gradação normal, com as areias na base e pelitos predominando próximo ao topo da formação, enquanto no poço 15 os pelitos dominam a porção mediana. No poço 19, estranhamente, verifica-se a predominância de pelitos na porção inferior da seção, o que pode ser resultado de uma definição equivocada dos limites entre as formações Potí e Piauí. No poço 19 são encontradas rochas carbonáticas na porção mediana e superior da Formação Piauil, como também na base da Formação Pedra de Fogo, enquanto no poço 15 os carbonatos estão restritos à região de contato entre as duas formações. O poço 18 exibe pouco mais de $50 \mathrm{~m}$ da Formação Piauí. Em todos os poços a perfuração foi iniciada em afloramentos que correspondem a base da Formação Pedra de Fogo, exceto no poço 18 (Formação Piaui) e em nenhum poço encontraram-se evaporitos.

\section{Seção Estratigráfica Leste - Oeste}

Esta seção estratigráfica (Fig. 3.4.6) se mostrou uma das mais importantes para o estudo da Seqüência Permo-Pensilvaniana da Bacia do Parnaiba. Na sua construção e interpretação, foram utilizados os perfis compostos e testemunhos de sondagens dos poços 5, 6, 4, 7 e 8 (Fig. 9.4.1). Ela foi construída segundo a direção geral leste-oeste com ligeira inflexão para nordeste.

Os corpos arenosos que ocorrem na base da Formação Piauí, bem definidos na seção estratigráfica da borda leste, aparecem nesta seção com aumento de espessuras das bordas para o centro da bacia e com sutil aumento de leste para oeste. No poço 4 estas camadas arenosas ultrapassam os $100 \mathrm{~m}$ de espessura acumulada, enquanto no poço 8 não atingem $15 \mathrm{~m}$. Não existe uma definição aparente de tendências na distribuição dos corpos areníticos ao longo dos poços desta seção. Por exemplo, no poço 8 as maiores espessuras ocorrem na porção superior da Formação Plauí, no poço 7 os 
SEÇÃO ESTRATIGRÁFICA LESTE - OESTE

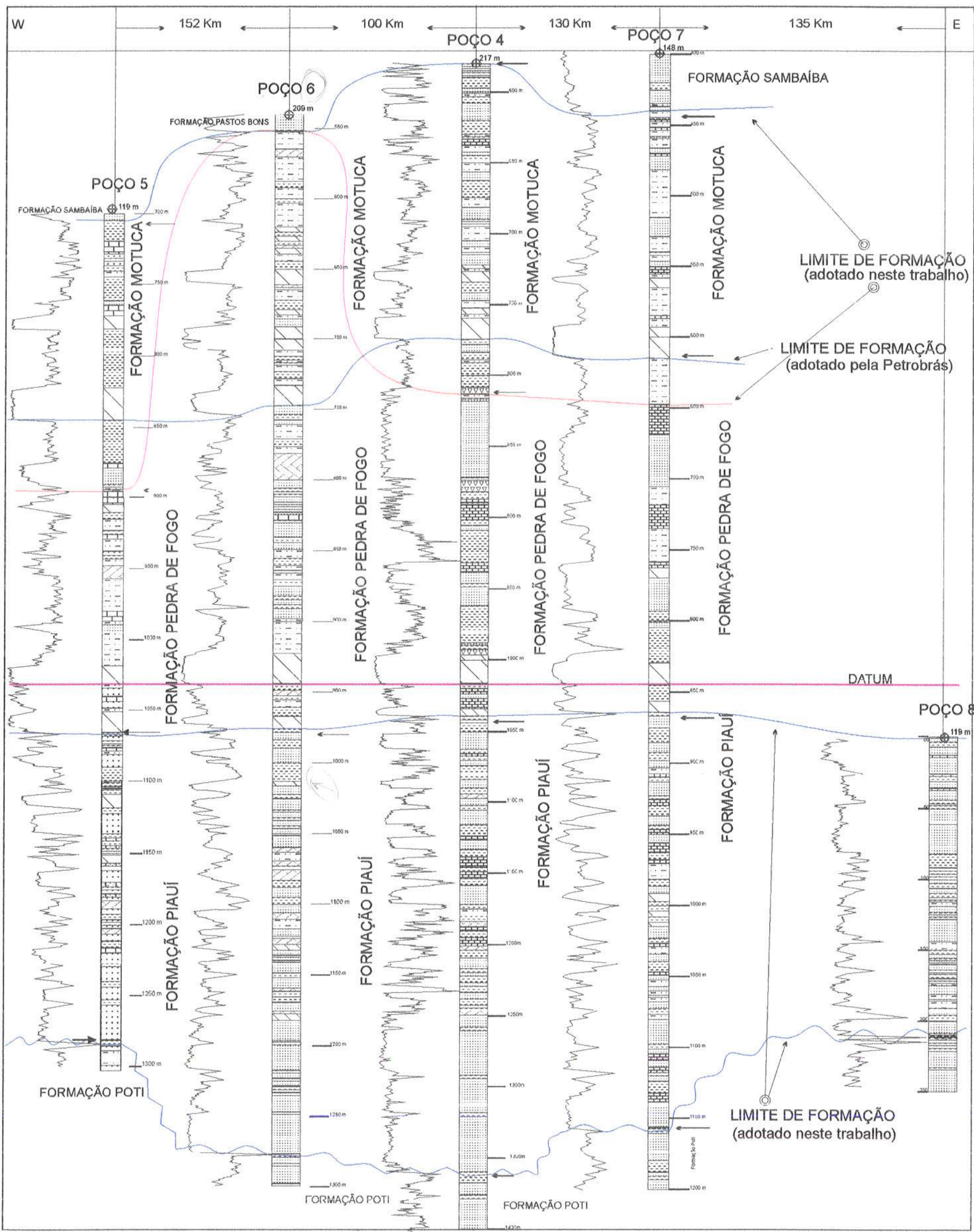

Fig. 3.4.4 - Seção estratigráfica leste - oeste com os novos limites de formação propostos neste trabalho para as Formação Pedra de Fogo e Motuca. Os poços $5,6,4$, e 7 estão situados na porção mais central da bacia e correspondem a prováveis depocentros. 
pacotes mais espessos se concentram na base e topo da formação. $O$ poço 4 concentra os arenitos na base e, subordinadamente, no topo, comportamento semelhante ao poço 6. Com exceção do poço 8 , nos demais poços não se encontram os arenitos superiores (Arenito Saraiva), marcantes na borda leste da bacia. Esta diversidade de distribuição é creditada principalmente ao longo espaçamento existente entre os poços. Também os carbonatos apresentam uma distribuição aparentemente aleatória: no poço 8 ocorrem restritos a porção superior; os poços 7 e 5 apresentam-se com carbonatos desde as posições mais inferiores, contrário ao que se encontra na literatura, (restrito às porções superiores da Formação Piaui). Os evaporitos ocorrem com maior representatividade no poços 5 e 7, não sendo encontrados nos poços 8 e 4 . Inversamente, os folhelhos são mais abundantes no poço 8 e na borda oeste, o que deve-se, provavelmente, a inflexão desta seção estratigráfica para direção nordeste, mais próximo de uma das possivel ligação da bacia com o mar. Ressalta-se a variação de espessura da Formação Piaui, que atinge mais de $300 \mathrm{~m}$ na porção central da bacia (poço 4) e pouco mais de 200 $\mathrm{m}$ na borda leste.

$\mathrm{Na}$ Formação Pedra de Fogo os corpos arenosos mais espessos ocorrem principalmente na porção mediana e superior da borda leste (poços 4 e 7). Para oeste ocorrem como corpos isolados restritos ao poço 6. Os evaporitos se concentram na porção basal, entretanto, para leste persistem por mais de $100 \mathrm{~m}$ da base, já na porção mediana do poço 7. Nos poços situados mais ao centro da bacia não há ocorrência de evaporitos na porção mediana e superior, voltando a ser encontrados apenas na porção superior do poço 5 , na borda oeste. Os corpos carbonatos ocorrem por toda extensão desta seção estratigráfica mostrando-se mais abundantes na porção superior da borda leste (poços 4 e 7 ). Os pelitos são abundantes por toda seção predominando na borda oeste.

A Formação Motuca apresenta-se em subsuperfície como a menos arenosa das três formações. Os corpos areníticos ocorrem restritos aos poços 4 e 7 , situados na borda leste, onde aparecem com pequena espessura, desde a porção inferior no poço 4. $\mathrm{Na}$ porção média e superior ocorrem corpos de maior espessura no poço 7. Os evaporitos são abundantes na porção basal e mediana da formação, diminuindo de espessura e de freqüência para o topo. Apresentam-se mais significativamente na borda oeste (poços 5 e 6). Os carbonatos estão presentes em todos os poços, entretanto, são pouco comuns na porção basal (poço 7) ocorrendo com maior freqüência na porção superior. 


\section{5 - SISTEMAS DEPOSICIONAIS}

O conhecimento hoje adquirido sobre os sistemas deposicionais da Bacia do Parnaíba representa o somatório de um lento processo de acúmulo de informações, que remota aos trabalhos dos pioneiros geocientistas. Entretanto, seu refinamento deve-se principalmente à Petrobrás, por ocasião da implantação do curso de Sistemas Deposicionais, no final da década de 70 , criado e divulgado inicialmente pelo Dr. Jorge Della Fávera e Rodi Ávila Medeiros.

Para a Seqüência Permo-Pensilvaniana da Bacia do Parnaíba a situação não difere do panorama geral da bacia. Hoje interpreta-se ali os sistemas deposicionais fluvial, de dunas eólicas (desérticas e costeiras), de plataformas carbonáticas, lagunar, deltaico etc. Neste tópico, não se objetiva fazer uma revisão bibliográfica ou uma caracterização sistemática dos sistemas interpretados, para tanto encontram-se algumas referências como (Mesner \& Wooldridge, 1964; Leite et al., 1975; Lima \& Leite, 1978; Campanha \& Rocha Campos, 1979; Della Fávera, 1980, 1982, 1984, 1990; Faria Jr. \& Truckenbrodt, 1980; Coimbra, 1983; Faria Jr.,1984; Lima Fitho, 1991a; Lima Filho \& Rocha Campos, 1993; Góes, 1995; Lima Filho, et al., 1995, dentre outros). Pretende-se aqui fazer a caracterização do contexto costeiro/marinho raso para a base da Seqüência PermoPensilvaniana, em especial do detalhamento da influência de marés e de seu controle alocíclico astronômico. Desta forma, se justifica a aplicação dos conceitos da Estratigrafia de Seqüências para montagem do arcabouço temporal numa situação mais próxima da ideal. A necessidade desta caracterização se faz sentir devido o estágio ainda precoce da aplicação da Estratigrafia de Seqüências em sucessões continentais.

Neste exercício de aplicação foi escolhido o perfil da Baixa Fria. Por apresentar as melhores exposições de depósitos controlados por marés.

\section{1 - SISTEMAS DEPOSICIONAIS DO PERFIL DA BAIXA FRIA}

Tanto o perfil da Baixa Fria quanto os perfis Alegria e de Santa Rita apresentam-se no mesmo contexto costeiro e marinho raso. No perfil da Baixa Fria os arenitos representados pela fácies AmCi, AfPp, AfmCa e AfSLs são interpretados como possível registro da sedimentação que ocorreu durante o rebaixamento do nível do mar que expôs a plataforma carbonífera, após a deposição da Formação Poti (Fig. 1.5.1). Este 
rebaixamento seria responsável pela instalação de incisões na plataforma (formação de vales incisos) geradas pelo aumento do gradiente fluvial, devido a queda brusca do nível de base. Os arenitos inferiores, conglomeráticos, imaturos mineralogicamente, com paleocorrentes para SW e NE são interpretados como depositados em vales incisos. Acima dos arenitos conglomeráticos ocorrem arenitos com paleocorrentes predominando para SW, com geometria tabular e sigmóide. Estes depósitos são interpretados como os primeiros sinais de elevação do nivel relativo do mar, num contexto de afogamento fluvial. Após este momento há uma grande subida na taxa elevação do nível relativo do mar e são depositados lamitos e arenitos finos de plataforma sobre os depósitos arenosos mais grossos de origem fluvial e de marés (proximais). A sedimentação mais fina compreendendo as fácies AfSW, FPp, AmgCt e LWyLF, as quais sugerem uma deposição em plataforma retrabalhada por ondas de tempestade. As principais evidências da ação de ondas de tempestade são as presenças de gutter cast, de marcas de ondas e a gradação normal verificada nas camadas centimétricas (variando de areia média a lamito). Os gutter cast são particularmente abundantes em depósitos de nearshore, caracterizado por erosão e passagem (bypass) de sedimentos arenosos durante tempestades. Esta situação guarda alguma semelhança com o modelo apresentado por Myrow (1992a), onde a fácies com gutter cast representa a porção proximal de uma plataforma retrabalhada por ondas de tempestade, cuja porção mais distal é caracterizada por hummockys e turbiditos. E difere do modelo clássico conhecido (p.e. Aigner, 1982, 1985; Walker, 1984) por apresentar uma considerável redução na espessura de seus estratos na porção mais proximal da plataforma e por não conter swalley (substituídos pelos gutter cast) (Myrows, 1992b), como mostra a Figura. 2.5.1. São encontrados depósitos de praia (fácies AmfBa) bem caracterizados por estratificações de baixo ângulo, marcados por minerais pesados, e estruturas de deformação atectónica (Fig. 3.51). Acima destes depósitos, ainda em posição de nível de mar relativo elevado apresentam-se camadas de folhelhos intercaladas com camadas de arenitos fino/siltito interpretados como prováveis depósitos de pró-delta. No capítulo referente a Estratigrafia de Seqüencias será exibida uma seção estratigráfica envolvendo os perfis da Baixa Fria, Alegria e Santa Rita onde serão mostrados os sistema deposicionais interpretados para estes perfis e a relação espacial entre eles. Após um pequeno intervalo $(<2,5 \mathrm{~m}) \mathrm{sem}$ afloramentos o perfil é retomado com a presença de depósitos interpretados como 


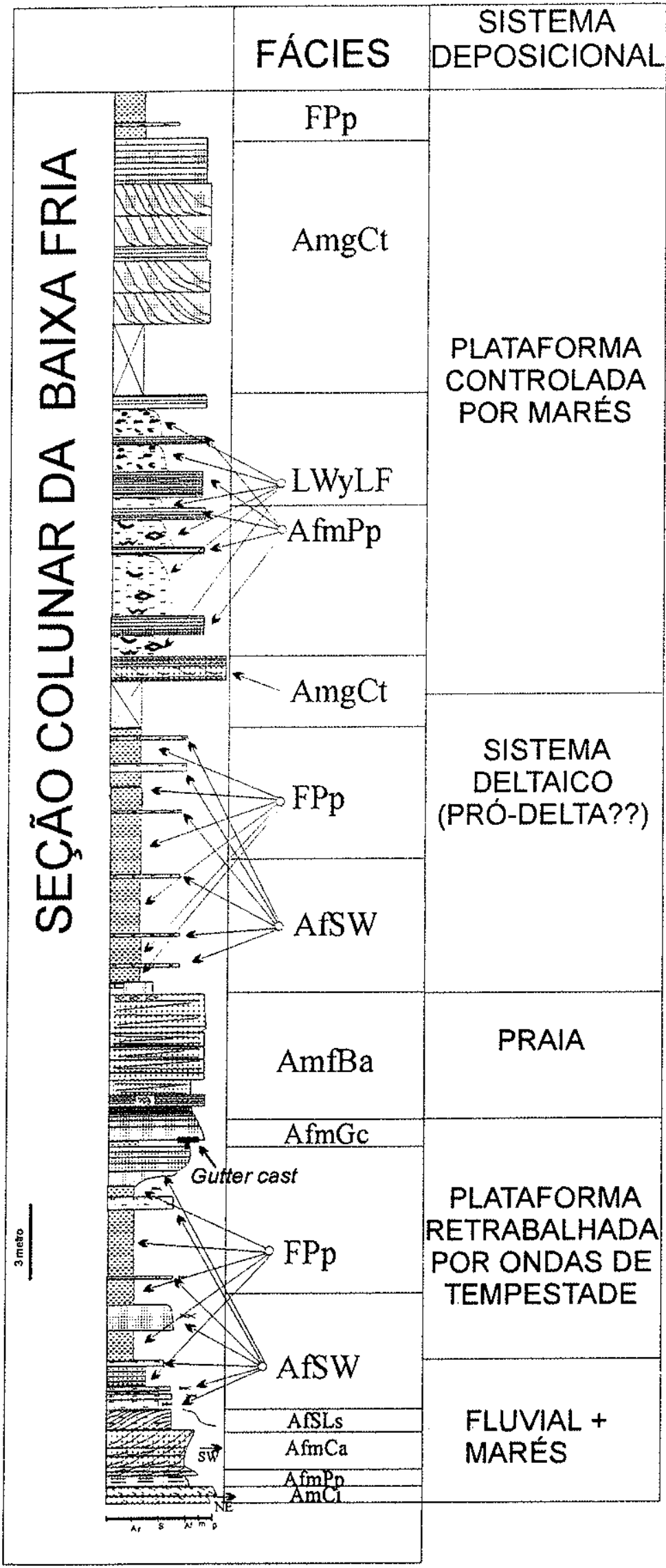

Fig. 1.5.1 - Relação entre as fácies e sistemas deposicionais do Perfil da Baixa Fria, na porção inferior da Seqüência Permo-Pensilvaniana, na borda leste da Bacia do Parnaíba.

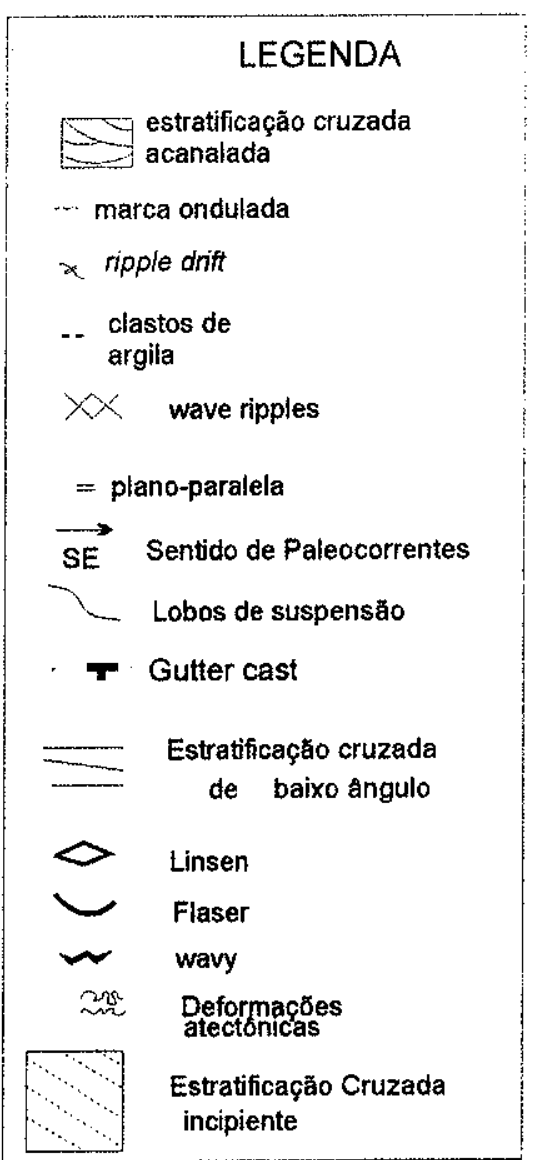



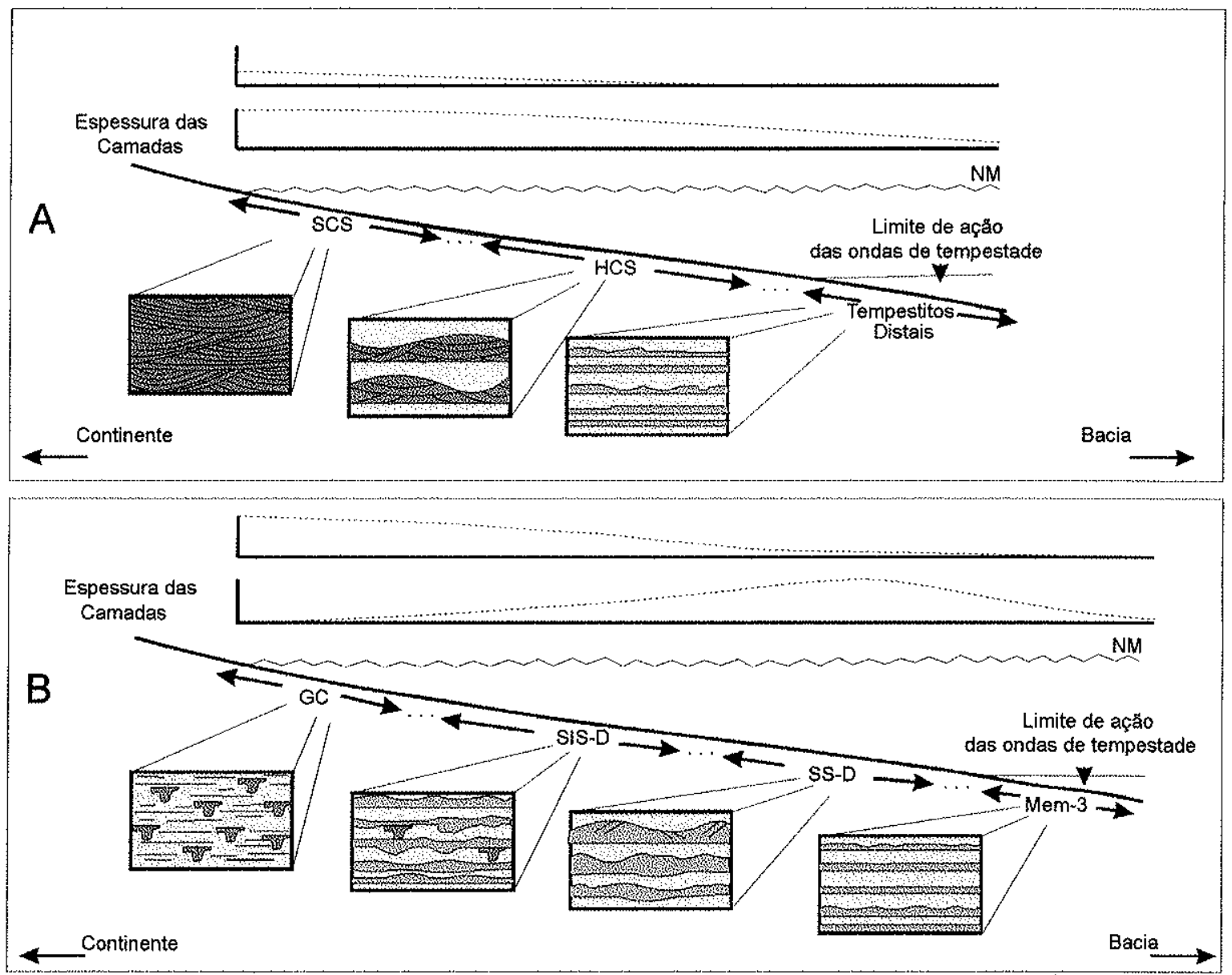

Fig. 2.5.1- Comparação entre modelos de plataformas dominadas por tempestade. "A" é o modelo clássico (Aigner, 1982) e "B" o modelo proposto Myrrow (1992). A presença de gutter cast (Foto 1- Estampa 3), marcas de ondas de médio porte e gradação normal em camadas centimétricas sugere a ação de ondas de tempestade, na seção da Baixa Fria, num modelo semelhante ao proposto por Myrrow (1992). 


\section{Legenda}

\begin{tabular}{|c|c|}
\hline & Marcas ondul \\
\hline & Swash \\
\hline 6 & Deformações \\
\hline & Gutter Cast \\
\hline & Arenito \\
\hline & Folhelho \\
\hline
\end{tabular}

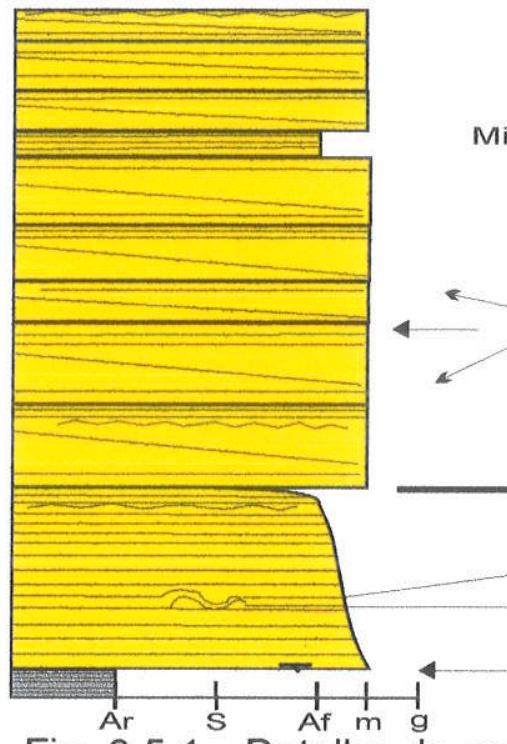

Minerais pesados

INTERMARÉS

Crostas laterítica

$0,5 \mathrm{~m}$

Argila

Areia Média

Gutter cast

ANTEPRAIA

Fig. 3.5.1 - Detalhe da seção Baixa Fria, onde são mostrado pacotes de arenitos, com estratificação de baixo ângulo, dobras atectônicas (Foto 2 Estampa 3), ressaltadas por minerais pesados, interpretados como sistema deposicional praial. 
de marés. Neste depósitos foi possivel realizar uma abordagem especial onde foi retratado o controle deposicional de fatores alocíclicos de causa astronômica.

A identificação de elementos que mostrem a contribuição da ação de marés na construção do registro geológico vem sendo significativamente refinada nos últimos anos. Entretanto, já desde a década de 50, inúmeros artigos vem contribuindo para aumentar o conhecimento de processos sedimentares envolvidos e do registro deixado pela ação das marés. Entretanto, apesar de todo acúmulo de conhecimento adquirido ao longo de quase meio século, em algumas situações especiais, é necessário buscar a resposta dos controles deposicionais em fatores extrabacias (alocíclicos). Mesmo a presença de bidirecionalidade de fluxo, que é um fator ainda considerado por muitos autores como critério para interpretação da ação de marés, pode ser inconsistente quando analisada descontextualizadamente. A partir de trabalhos, como os de Alam et al (1982) ou Van Straaten (1950), sabe-se que tanto podem ser encontradas estruturas sedimentares que indicam bidirecionalidade de fluxo em sistema fluvial, quanto também podem ser vistos canais de marés com registro de apenas uma direção de corrente. Estes artigos, dentre outros, reforçam a convicção de que para uma perfeita identificação da ação de marés é importante conhecer além dos processos e produtos que agem na bacia, o contexto na qual as fácies estão inseridas (visão holística) e o controle extrabacia a elas submetidos. Hoje, já é possivel o reconhecimento seguro da ação de marés, mesmo quando estruturas sedimentares características como: estratificação lenticular, estratificação ondulada, estratificação flaser, estratificação espinha de peixe (herring bone) e marcas onduladas de interferência (interference ripple), convencionalmente associadas à ação de marés, não são encontradas. Este avanço se deu com o reconhecimento de fatores alocíclicos sedimentares, derivados de causas astronômicas, associadas ao sistema Terra-Lua-Sol.

A partir de Visser (1980), surgiu o interesse em estudar os depósitos de marés, do ponto de vista da ritmicidade dos estratos. Principalmente, quando as estruturas sedimentares acima citadas não são encontradas ou há interesse em ressaltar a associação da ritimicidade com causas astronômicas. Nestes casos, o estudo tem sido feito pela análise da variação na espessuras de estratificações cruzadas e de camadas argilosas associadas (bundles) de supostas barras de marés (p.e. Visser, op.cit; Allen 1981; De Borer et al. 1989); ou, mais recentemente, pela alternância de espessuras de 
lâminas de arenito/siltito e siltito/argilito (Kvale \& Archer, 1990, 1991; Kueccher et al.1990; Lainer et al. 1993; Martino \& Sanderson, 1993; Greb \& Archer, 1995). As variações cíclicas de espessura interna de cada lâmina/camada de siltito/argilito ou de médias/grandes bundles refletem uma relativa quietude ou alta energia no ambiente deposicional, que pode ser gerada por causas diárias como as marés de enchentes e vazantes; por causas quinzenais como as marés de sizígia e quadratura; por causas mensais como as marés de apogeu e perigeu; ou ainda por causas semestrais/anuais influenciadas pelo solstício e equinócio (Martino \& Sanderson, 1993; Greb \&Archer, 1995). Há na literatura numerosas publicações que mostram variações cíclicas no registro geológico geradas por diversas causas de maior ordem que aquelas da conjunção TerraLua-Sol, um exemplo é a variação na atividade solar gerada por manchas, cujo ciclo é da ordem de 11 anos (Fairbridge \& Sanders, 1987); outra corresponde a variáveis astronômicas do sistema Terra-Sol, conhecidos como efeito de Milankovitch.

A chave para o reconhecimento das causas da ciclicidade em depósitos controlados por marés é a precisa identificação da variação da espessura das lâminas/camadas. Estes ciclos, de uma forma generalizada, podem ser agrupados em conjuntos de 11 a 14 camadas que refletem variação de marés de sizígia e quadratura; de 24-35 camadas que são construídos em resposta a variações da maré resultante da influência da órbita elíptica da lua; de 100 a 166 camadas cuja amplitude é definida pela influência de variações sazonais, como os solstícios (inverno e verão), que resultam em espessuras relativas máximas de estratos, e equinócio (primavera e outono), que apresentam espessuras relativas mínimas (Martino \& Sanderson, 1993; Lanier et al., 1993; Greb \& Archer, 1995).

Contudo, estudos em plataformas modernas, afetadas por marés, mostram que é comum a ausência de uma ou mais camadas/lâmimas. Segal \& Kuehl (1994), analizando interlaminações de silte a argila da plataforma interna de Bengala (Golfo de Bengala), constataram ciclos de marés produzidos por marés de sizígia e quadratura. Em 100 lâminas analizadas e 6 ciclos definidos, há uma notável ausência de camadas em quase todos os ciclos. Considera-se que um ciclo "normal" de marés de sizígia/quadratura corresponderia a 11 ou 14 lâminas. Entretando, predominam ciclos incompletos, onde alguns mostravam apenas 5,8 , ou 9 lâminas. Para estes autores, os ciclos são mais pronunciados no período de inverno, quando não ocorrem altas descargas fluviais, tão comuns no verão. Mesmo em estudos como os de Segal \& Kuehl (op. cit.) em sedimentos 
recentes que ainda não foram submetidos à ação dos processos diagenéticos, observa-se a forte presença de ruidos que modificam o número ideal de lâminas esperado. Portanto, estes ruidos precisam ser conhecidos e considerados. Segundo Martino \& Sanderson (1993), os ruídos podem ser gerados quando: a) há ampla ocorrência de marcas onduladas que produzem variabilidade lateral na espessura das camadas arenosas; b) estão presentes, em pequena escala, escavação (scouring) e/ou bioturbação (burrowing) que podem causar mudanças na espessura original de camadas arenosas e na continuidade de drapes de folhelhos; c) verifica-se amalgamento de diversas camadas em um único corpo. Pode-se incluir também o ruído gerado pela descarga fluvial em período de enchentes, normalmente no verão (Segal \& Kuehl, 1994), ou ainda a ação de tempestades que também podem suprimir ou depositar camadas com espessura anômalas.

Em função da presença de ruídos, pode-se, dependendo de sua intensidade, ter a ciclicidade mascarada, ou menos pronunciada. Para testar a periodicidade da repetição das camadas/lâminas e estimar o período faz-se uso de métodos estatísticos como análise de Fourier (power spectrum) ou autocorrelação (Yang \& Nio, 1985; Martino \& Sanderson, 1993). Já o uso de filtros específicos pode separar diferentes componentes da seqüencia, mostrando, por exemplo, a presença de marés de quadratura/sizígia, de variações de longa duração, variações aleatórias, como também pode-se estimar a importância relativa de cada componente.

No perfil da Baixa Fria e em vários outros afloramentos da região, são encontrados freqüentemente depósitos de marés. Na porção superior deste perfil (Fig.4.5.1) foram identificados estratos (fácies AWL e LWL) interpretados como depositados em região de intermarés e inframarés. Estes estratos são caracterizados por intercalações de lamitos, com gradação normal, e arenitos finos com laminação plano-paralela. As camadas lamíticas, mostram-se arenosas na base (areia fina a muito fina), com flaser nas calhas das marcas onduladas, passando gradativamente, para argilosas no topo, com laminação onduladas e lenticulares. $\mathrm{Na}$ base dos estratos lamosos, as camadas (centimétricas) estão amalgamadas, dificultando a identificação de suas espessuras, entretanto, para cima, tornam-se mais separadas e mais facilmente identificáveis.

Foram medidas as espessuras destas camadas/lâminas e plotados os valores em gráfico cartesiano, onde o eixo $\mathrm{Y}$ corresponde às espessuras das camadas/lâminas e 0 


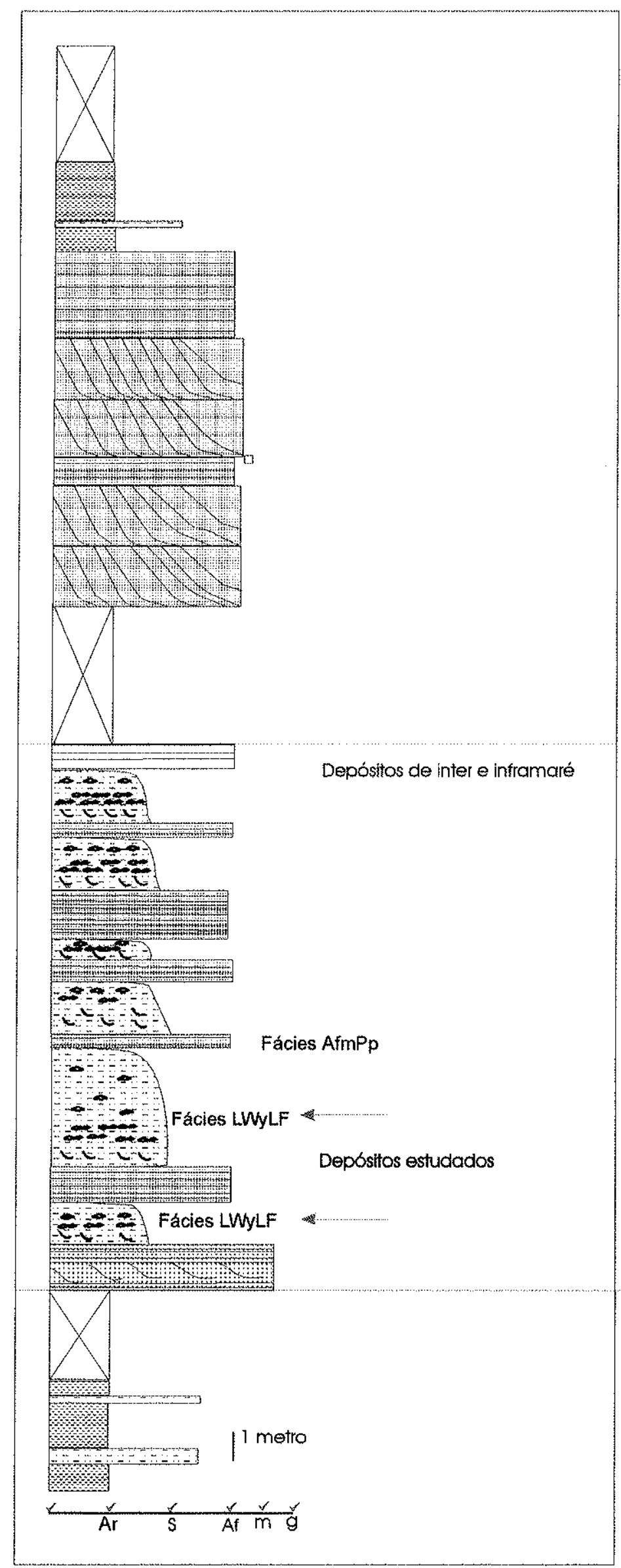

Fig. 4.5.7 - Parte superior do perfil da Baixa Fria (Fig. 1.5.1) onde ocorrem os depósitos de maré estudados quanto a clclicidade de seus depósitos. 
eixo $\mathrm{X}$ o número de camadas/lâminas. $O$ gráfico obtido mostra um padrão cíclico regular, com aparentes ciclos de várias ordens como, por exemplo, ciclos variando de 9 a 14 camadas, de 20 a 26 camadas ou ciclos variando de 42 a 46 camadas (Fig.5.5.1). Estes valores de espessuras analisados com a transformada de Fourier mostram mais claramente a ciclicidade envolvida. A partir desta análise, usando o método power spectrum, são identificados os ciclos mais importantes, 42, 21 e 16 camadas (Fig. 6.5.1).

Uma vez que o padrão de marés do Pensilvaniano é similar ao atual (Greb \& Archer, 1995), podem ser encontrados registros de marés semi-diurno ou diurno. Considerando o primeiro caso, essas marés ocorrem representadas por duas marés de enchente e duas de vazante, durante o período de 12 horas, embora, geralmente haja o predominio de uma maré sobre a outra, dai a denominação "maré predominante" e "maré subordinada", respectivamente. $\mathrm{Na}$ presença de marés predominante, podem ser construidos diariamente até dois registros, como pares conjugados de argila (mud couple), bundles, etc. Já que o mês lunar tem 28 dias, pode-se ter em um mês o número ideal de 36 registros onde há uma maré predominante e 56 registros onde as marés possuem amplitude semelhante. Da mesma forma, em um mês lunar ocorre uma fase de lua cheia e uma fase de lua nova, responsáveis mensalmente por duas marés de sizígia, enquanto as luas em quarto-crescente e quarto-minguante são responsáveis pelas marés de quadratura. As marés de sizígia, com sua maior variação da amplitude, têm também maior poder de transporte sedimentar, logo, cada registro tem as espessuras aumentadas neste período, enquanto, durante o periodo de quadratura os espessuras são mínimas. Logo, durante os períodos de sizígia verifica-se que as camadas apresentam a maior espessura e após 7 dias ocorrem camadas de espessura mínima, ou seja a cada 14 registros tem-se a presença das marés de sizígia e quadratura, respectivamente.

Há boa correlação entre os dados obtidos pelo power spectrum (com ciclos de 15, 21 e 42 camadas) com os valores teóricos ideais. Logo, pode-se inferir ciclos construídos a partir da variação da influência de marés de sizígia-quadratura (valor ideal de 7 dias ou 14 registro) para o valor obtido de 15 camadas no terceiro pico; ou ciclos construídos a partir da influência de marés de sizigia-sizígia ou quadratura-quadratura (valor ideal de 14 dias ou 28 registros) para o segundo pico, de 21 camadas; ou ainda ciclos de variação do mês lunar (valor ideal de 28 dias ou 56 registros) para o primeiro pico de 42 registros. 


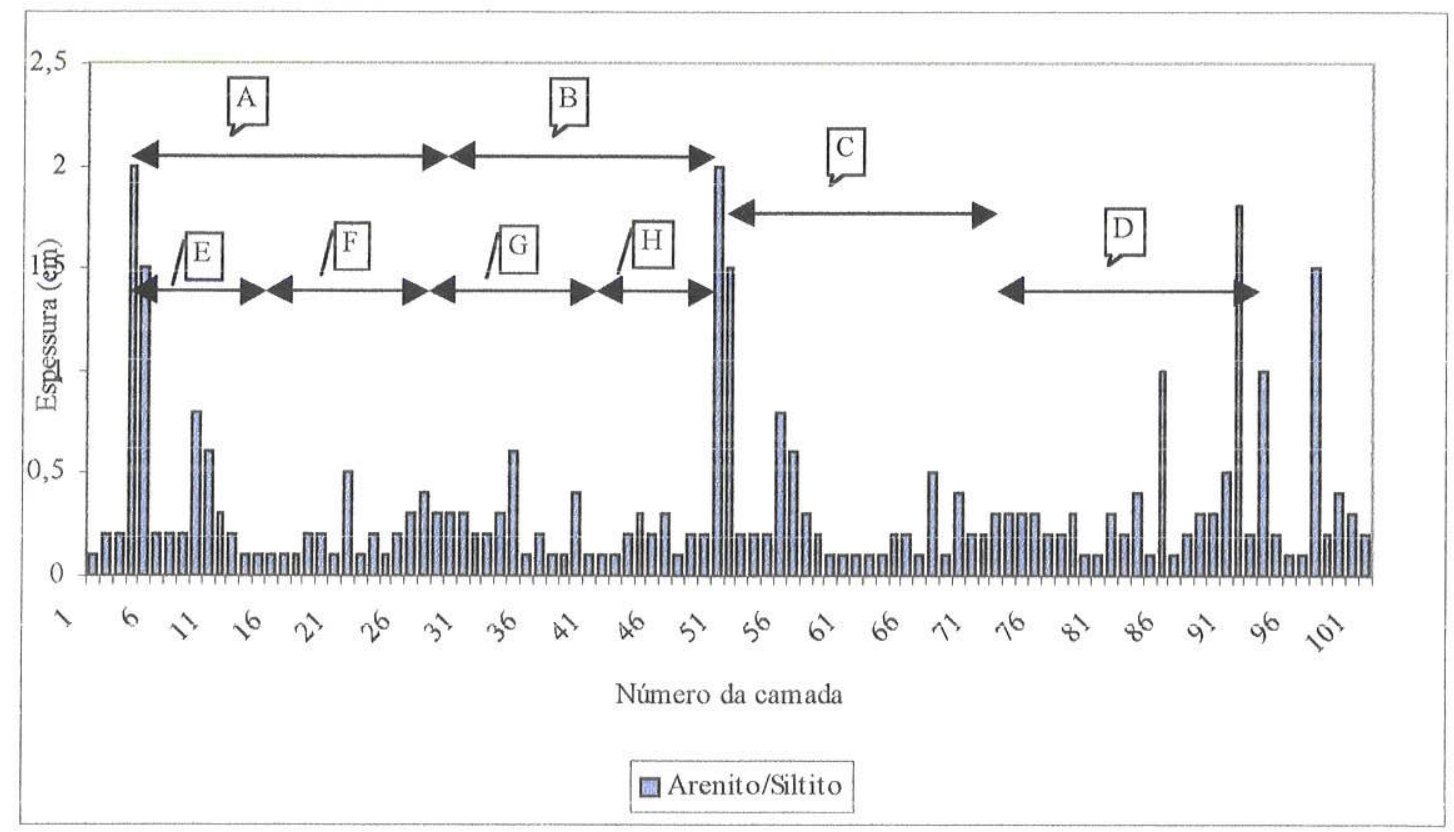

Fig. 5.5.1 - Ciclos rítimicos em ambiente marinho raso, controlado por marés, onde são identificadas várias ordens de ciclicidade. Veja no texto para melhor entendimento ( $A=26$, $B=22, C=22, D=20 ; E=12, F=14, G=13, H=9$ ).

\section{CICLOS DE MARÉS}

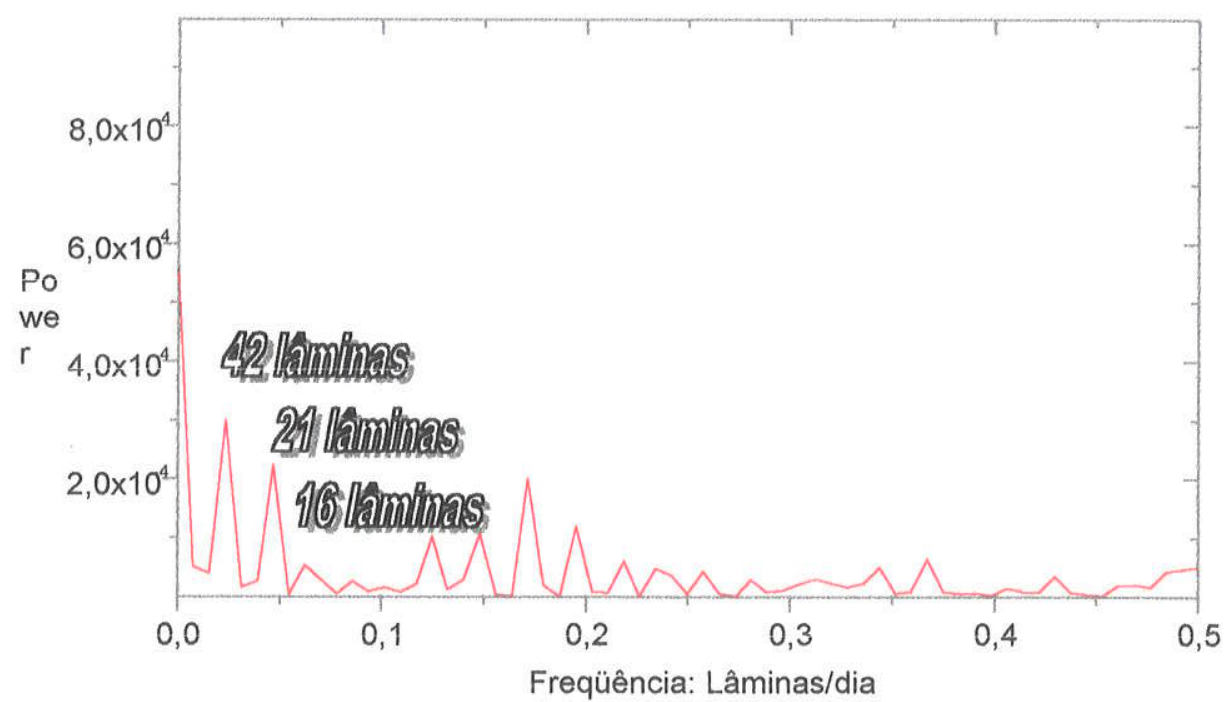

Fig. 6.5.1 - Os três principais ciclos de marés detectados com 41, 21 e 16 lâminas, formadas respectivamente por ciclos de apogeu e perigeu lunar, ciclo de quadratura/sizígia e ciclo de sizígia-quadratura. 


\section{6 - Estratigrafia de Seqüências}

\section{1-introdução}

A evolução da Geologia Sedimentar envolveu três grandes revoluções, duas delas iniciadas na década de 60 e a terceira, denominada de Estratigrafia de seqüências, fortemente embasada nas duas primeiras, surgida no final da década de 70 (Miall, 1995). A primeira revolução teve seu ápice no início dos anos 70 , com a consolidação do modelo sedimentar processo-resposta. Era a emergência dos conceitos de regime de fluxo que unificavam as teorias que explicavam as origens das estruturas sedimentares hidrodinâmicas. Na mesma época, a Sedimentologia atingia a maturidade no estudo de seções delgadas de rochas, acompanhada do surgimento de artigos enfocando análises de fácies, sucessão de fácies, processos sedimentares e modelos estratigráficos regionais. A base científica para esta revolução foi o uniformitarismo lyelliano (Miall, op. cit.). A segunda, derivada de outra revolução mais ampla nas geociências, a teoria de Tectônica Global de Placas, resultou na combinação dos avanços obtidos com essa teoria e outros alcançados na área da Geodinâmica, que envolvem investigações dos processos mantélicos e crustais profundos, propiciando a base para o que ficou conhecido como Análise de Bacias. Ou seja, o estudo da origem e desenvolvimento de bacias sedimentares, incluindo sua história deposicional e estrutural (Miall, op. cit.). Apesar das idéias precursoras da terceira revolução (a relação entre sedimentação e variação do nível do mar e tectônica) terem sido esboçadas ainda no século passado por Suess, Gressly, Walther, Barrell e Grabau, elas ficaram no esquecimento da comunidade científica por um longo tempo. Contudo, os conceitos básicos da estratigrafia de seqüências só foram inicialmente elaborados no final da década de 40 (Sloss et al., 1949), tendo sido novamente retornados no final de $50 \mathrm{com}$ Wheeler $(1958,1959)$ e início da década de 60 , novamente com Sloss (1963). O arcaboço básico da estratigrafia de seqüências foi delineado até a década de 60 . Entretanto, talvez porque os sedimentólogos estivessem absortos com o modelo de processo-resposta ou mesmo porque ainda não existissem dados regionais suficientes, a revolução não aconteceu. É provável também que a ausência de uma tecnologia que permitisse o tratamento sistemático de um grande volume de dados também servisse de impecitho para o início da revolução. Sem dúvida, o grande 
avanço na área de computação e na aquisição de dados sísmicos foi um fator decisivo. Estas idéias só iriam florescer a partir dos trabalhos de Peter Vail (um ex-aluno de Sloss), fazendo uso de dados de sísmica de reflexão para interpretação da arquitetura estratigráfica em larga escala. O resultado explodiu no cenário estratigráfico com a publicação da Memoir 26 da AAPG (Payton, 1977). Para Miall (op. cit.), o trabalho de Vail e colaboradores (Vail et al., 1977; Mitchum et al., 1977) contém dois novos e importantes conceitos. O primeiro diz respeito à arquitetura estratigráfica, que em grande escala pode ser relacionada a ciclos de elevação e queda do nível do mar; o segundo, implica em que estes ciclos podem ser correlacionados globalmente, sugerindo que a mudança global no nivel do mar, ou eustasia, é o principal processo controlador do arcaboço estratigráfico.

Segundo Emery \& Myers (1998), existem muitas definições para Estratigrafia de Seqüencias, entretanto, a mais simples é também a preferida pelos autores, pode ser resumida como "a subdivisão do preenchimento de uma bacia sedimentar em pacotes limitados por inconformidades e suas conformidades correlativas", onde as inconformidades e conformidades correlativas são os limites de seqüências. Esta definição tem como base Mitchum et al. (1977), e está de acordo com Wilgus et al. (1988) e Van Wagoner et al. (1990).

A Estratigrafia de Seqüências é uma importante ferramenta usada para montar o arcabouço crono-estratigráfico de uma bacia sedimentar, de forma que possa ser usado tanto para correlação e mapeamento de fácies sedimentares, quanto também como um preditor na estratigrafia. Ela encontra-se intrinsicamente relacionada a sismoestratigrafia, a bioestratigrafia, a crono-estratigrafia e a sedimentologia, entretanto, a litoestratigrafia não é útil a esta nova abordagem, exceto por fornecer à Estratigrafia de Seqüências o invólucro dos intervalos limites que estão confinados (Emery, 1998). A aplicação da Estratigrafia de Seqüências depende do reconhecimento da hierarquia das unidades estratais, tais como as camadas, conjuntos de camadas, parasseqüências, conjuntos de parasseqüências e seqüencias, esta última limitada por superfícies de erosão cronoestratigraficamente significantes, por superfícies de não-deposição ou ainda por suas superfícies correlativas (Van Wagoner et al. 1990). As seqüências e seus componentes estratais são interpretados como formados em resposta à interação entre as taxas de eustasia, subsidência e suprimento sedimentar. Estas interações podem ser modeladas e 
os modelos utilizados para predição da relação de estratos e para inferir idades em áreas onde os dados geológicos são limitados (Van Wagoner et al. 1988).

Van Wagoner et al. (1990) e Emery (1998) apresentam um quadro evolutivo das duas últimas décadas de evolução da Estratigrafia de Seqüências, ressaltando os principais marcos da revolução. Vale ressaltar que o modelo conceitual da Estratigrafia de Seqüências foi desenvolvido a partir de dados geológicos obtidos em bacias de margem passiva. Conseqüentemente, seu uso em outros tipos de bacias pode requerer adaptações, ou mesmo ser inviável. Pode-se citar, como exemplo, a aplicação diferenciada em bacias do tipo foreland (Swift et al., 1987; Posamentier e Allen, 1993).

É natural, como em qualquer revolução científica, que na fase de arrumação, críticas/contribuições possam modificar ou complementar as idéias iniciais (p.e., Miall, 1991,1994 e 1992). Aparentemente, a nova fronteira da Estratigrafia de Seqüências diz. respeito a compreensão da arquitetura da pilha sedimentar onde o mar não controlou diretamente a sedimentação. Neste sentido, já foram apresentados importantes contribuições com as aplicações adaptadas da Estratigrafia de Seqüências em depósitos aluviais (Legarreta e Uliana, 1991 apud Shanley e McCabe, 1994; Wright e Marriott, 1993; Shanley e McCabe, 1994; Zhang, et al., 1997), em depósitos lacustres (Scholz e Rosendahl, 1988; Scholz et al., 1993) e em depósitos eólicos (Havholm e Kocureck, 1991).

Este método de análise estratigráfica, considerado um dos mais notáveis avanços científicos para a compreensão da arquitetura das bacias sedimentares, não é entretanto, o único. Galloway (1989), com base nos conceitos de episódios deposicionais de Frazier (1974), elaborou uma técnica para análise estratigráfica de bacias denominada de estratigrafia genética. Para Galloway (op. cit.) a unidade fundamental é também a seqüência, denominada de seqüência estratigráfica genética, a qual constitui-se numa unidade deposicional regressiva limitada por superfícies transgressivas. Outro método de análise estratigráfica, é feito pela observação dos ciclos transgressivos-regressivos. Este método é muito semelhante ao de Galloway (1989), e ambos baseiam-se na determinação de uma superfície transgressiva no topo de uma unidade regressiva, ou numa superfície de máxima inundação para correlação regional.

Van Wagoner et al. (1990) discutem as vantagens da Estratigrafia de Seqüências sobre a Estratigrafia Genética. Dentre os argumentos citados estes três parecem mais relevantes: a) o limite de seqüência sensu Mitchum (1977) e Van Wagoner et al., (1988) é 
uma simples e ampla superfície que separa todas as rochas acima e abaixo deste limite. Embora todos os pontos sobre a superfície limitante de seqüência não representem o mesmo tempo, um instante é comum a todos os pontos. Este sincronismo no âmbito da bacia é interpretado como sendo global dentro dos limites da datação bioestratigráfica. Por esta razão, o limite de seqüência tem um significado cronoestratigráfico; b) O limite de seqüências sensu Mitchum (1977) forma-se independentemente da taxa de suprimento sedimentar. Uma rápida queda relativa do nível do mar, acompanhada de um grande suprimento sedimentar irá resultar em um limite de seqüência fortemente marcado por truncamentos (truncation). Uma rápida queda relativa do nivel do mar, com pouco suprimento sedimentar liberado lentamente resultará num limite de seqüência marcado por ampla exposição subaérea, mas com pouco truncamento. Em contraste, transgressões e regressões que definem as seqüências genéticas são fortemente controladas pelo suprimento sedimentar, por esta razão podem não ser sincrônicos; c) Há duas grandes superfícies transgressivas dentro da seqüência. A primeira superfície de inundação marca - limite superior do trato de sistema de mar baixo (TSMB) enquanto a segunda é a superfície de máxima inundação marinha (SIM), associada à seção condensada. Tipicamente, são encontradas diversas outras superfícies transgressivas limitando parasseqüências, dentro do trato de sistemas transgressivos (TST). Todas estas superficies podem, potencialmente, gerar confusão em correlações regionais, especialmente se os dados usados para correlação estão amplamente espaçados. A idade de cada superfície transgressiva dentro de uma seqüência em diferentes pontos da bacia pode diferir significativamente, dependendo das variações no suprimento sedimentar regional.

Para Myers \& Milton (1998) é válido o uso de superfície limitante de seqüência, máxima superfície de inundação ou máxima superfície de progradação para divisão estratigráfica, onde cada uma delas apresenta vantagens e desvantagens na sua utilização como uma superfície estratigráfica primária. Entretanto, consideram que a seqüência genética (sensu Galloway, 1998) não representa um fim por si só. A reconstrução paleogeográfica e uma completa compreensão da distribuição espacial das fácies de uma bacia só é possivel pela divisão em tratos de sistemas, o que requer a identificação dos limites de seqüências, das superfícies transgressivas e das superfícies de máxima inundação marinha. 


\section{2- A hierarquia das unidades estratais}

O reconhecimento das unidades estratais e seu uso para cronocorrelação e correlação de fácies é a essência da estratigrafia de seqüência. Cada unidade estratal é hierarquicamente identificada e definida somente pelas relações físicas dos estratos, incluindo continuidade lateral e geometria da superfície limitante das unidades, a forma do empilhamento vertical e a geometria lateral dos estratos dentro das unidades. A interpretação das fácies e ambientes de deposição de cada estrato acima e abaixo da superfície limitante é crítica, especialmente para definição das parasseqüências, conjunto de parasseqüência e na identificação dos limites de seqüência. As parasseqüências e seqüências podem ser identificadas em perfis de poços, testemunhos ou afloramentos e utilizados para construção do arcaboço estratigráfico da bacia (Van Wagoner et al., 1990).

\section{3- Unidades estratais}

Van Wagoner et al. (1990) reconhecem nos quatro componentes de um corpo sedimentar, identificados por Campbell (1967, apud Van Wagoner et al., 1990) como os blocos construtores das parasseqüências. Esses componentes são as lâminas, conjuntos de lâminas, camadas e conjuntos de camadas. Estes tipos de unidades estratais são geneticamente similares, mas diferem primariamente no intervalo de tempo para sua formação e na extensão em área das suas superficies limitantes. As superfícies que limitam estas unidades são definidas pela mudança na textura, terminações dos estratos e pela presença de paraconformidades, sendo marcadas por bioturbações, marcas de raizes ou paleosolos (Dunbar e Rogers, 1957). Estas superfícies formam-se relativamente rápido, variando de segundos a centenas de anos e são essencialmente sincrônicas em toda sua extensão (Campbell, 1967 apud Van Wagoner et al., 1990). O intervalo de tempo representado pelas superficies limitantes destas unidades estratais é provavelmente maior que $o$ intervalo de tempo representado pelas próprias camadas. Por estas razões, camadas e conjuntos de camadas podem ser comumente usadas para correlação cronoestratigráfica em amplas áreas e envolvendo vários sistemas deposicionais. Perfis de poços (com espaçamento entre 0,8 a $3 \mathrm{~km}$, especialmente 
aqueles onde estejam representados folhelhos marinhos ou seções argilosas) ou afloramentos contínuos podem fornecer dados com detalhes suficientes para se efetuar uma análise cronoestratigráfica com base nas características e distribuição espacial das camadas e das superfícies de conjuntos de camadas.

As unidades acima citadas são todas geneticamente relacionadas, limitadas por superfícies de erosão ou de não-deposição. Suas principais características estão citadas abaixo, segundo Campbell (1967, apud Van Wagoner et al., 1990). As lâminas são as menores unidades (megascópicas), tendo como principais características a uniformidade na textura, na composição e ausência de acamamento interno. Seu processo deposicional é episódico, envolvendo principalmente decantação e subordinadamente tração ou ambos. O tempo envolvido na deposição pode variar de minutos a horas, e as suas superfícies limitantes apresentam pequena área de extensão. Os conjuntos de lâminas são sucessões geneticamente relacionadas, limitadas por superfícies (chamada superfície de conjunto de lâmina) de erosão ou não deposição, ou por suas conformidades correlativas. Consistem de grupos ou conjuntos de lâminas concordantes que compõem distintas estruturas na camada. Seu processo deposicional é episódico e comumente são encontradas estruturas sedimentares que mostram a ação de ondas, de correntes e de fluxos turbiditicos. Formam-se em minutos a dias e sua superficie limitante possui também pequena extensão. As camadas são sucessões de lâminas oú conjuntos de lâminas limitadas por superfícies (chamadas de superfície de acamamento) de erosão, nãodeposição, ou por suas conformidades correlativas. Entretanto, nem todas camadas são formadas por lâminas e entre seus processos deposicionais podem estar envolvidos eventos episódicos ou periódicos. Os processos episódicos incluem depósitos de tempestade, inunditos, fluxo de detrítos e correntes de turbidez. As superfícies limitantes formam-se em minutos a anos, separando todos os estratos mais jovens de outros mais antigos sobre uma extensa superfície. As mudanças de fácies são limitadas por superfícies de acamamento. Estas superfícies limitantes podem ser usadas para cronocorrelação sobre certas circunstâncias. O tempo relacionado à formação dessas superfícies é maior que aquele relacionado a deposição das camadas. Sua área de extensão varia de $0,5 \mathrm{~m}^{2}$ a milhões de metros quadrados. Os conjuntos de camadas são sucessões de camadas limitadas por superfícies (chamadas de superficie de conjuntos de camadas) de erosão, de não deposição, ou por suas conformidades correlativas. As 
camadas acima e abaixo da superfície do conjunto de camada diferem na composição, textura, ou estrutura sedimentar de outros conjuntos de camadas. Os procesos deposicionais que agem aqui são os mesmos que atuam nas camada. As características das superfícies limitantes dos conjuntos de camadas são também as mesmas das superfícies limitantes das camadas, exceto por possuirem uma maior extensão.

\section{4- Parasseqüência}

A parasseqüência é uma sucesão de camadas ou de conjuntos de camadas geneticamente relacionados, relativamente concordantes, limitados por superfícies de inundação marinha ou por suas superfícies correlativas. Em posições especiais, dentro de uma seqüência, a parasseqüência pode ter um de seus limites coincidindo com o limite da seqüência. As parasseqüencias podem ter uma espessura variando da ordem de poucos metros a mais de $300 \mathrm{~m}$, enquanto sua extensão lateral pode variar de $15 \mathrm{~km}^{2}$ a $1.600 \mathrm{~km}^{2}$ e o tempo de formação $10^{2}$ a $10^{4}$ anos, sendo detectada em perfis de poços, testemunhos ou afloramentos. Muitas parasseqüências siliciclásticas são progradacionais e podem resultar de associações de fácies que mostram uma diminuição da profundidade para o topo (upward-shoaling), nas quais os conjuntos de camadas foram depositados progressivamente em águas mais rasas. Algumas parasseqüências siliciclásticas são agradacionais, mas também mostram a tendência de raseamento para o topo (shoal upward) (Van Wagoner et al., 1990).

As características das parasseqüencias com afinamento ou com aumento de espessura para o topo são mostrados nas figuras (1.6.4 e 2.6.4). Em uma típica parasseqüência com espessamento para o topo, os conjuntos de camadas aumentam de espessura para o topo, assim como os arenitos ficam mais grossos para cima e a relação entre arenitos/folhelhos também aumenta para o topo. Inversamente, em uma parasseqüência com afinamento para $\circ$ topo, os conjuntos de camadas têm suas espessuras diminuindo para cima, os arenitos tornam-se mais finos para cima (comumente culminando em argilitos e carvão), enquanto a relação arenito/folhelho também diminui nas camadas superiores. Em uma parasseqüência com upward-coarse ou upward-fining, em ambas as associações de fácies, são interpretadas como registrando uma gradual diminuição da profundidade da lâmina d'água (Van Wagoner et al., 1990). 


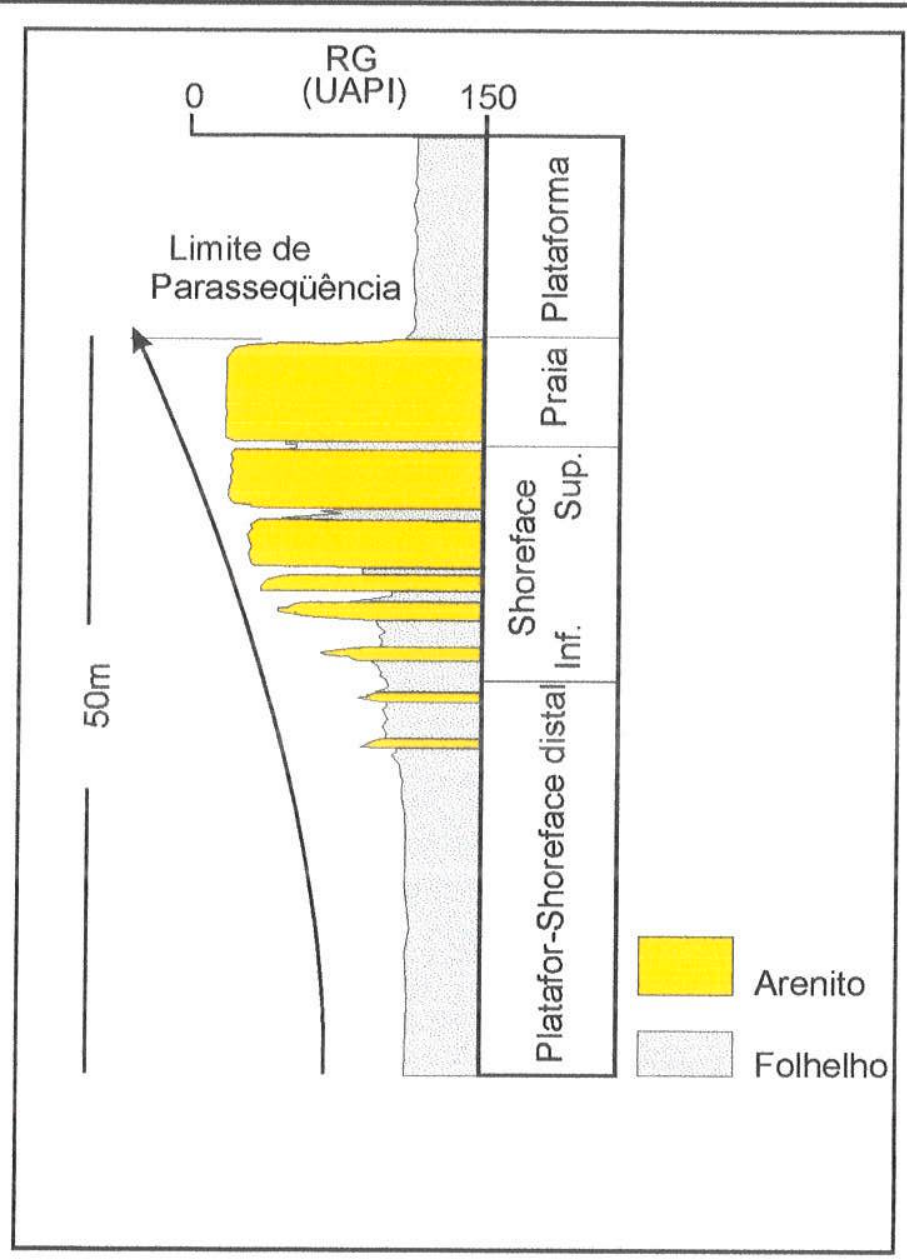

Fig. 1.6.4 - Parasseqüência com espessamento para o topo, formada em praia arenosa, num contexto de linha de praia dominada por processos fluviais e por ondas (Simplificado de Van Wagoner et al. 1990). 


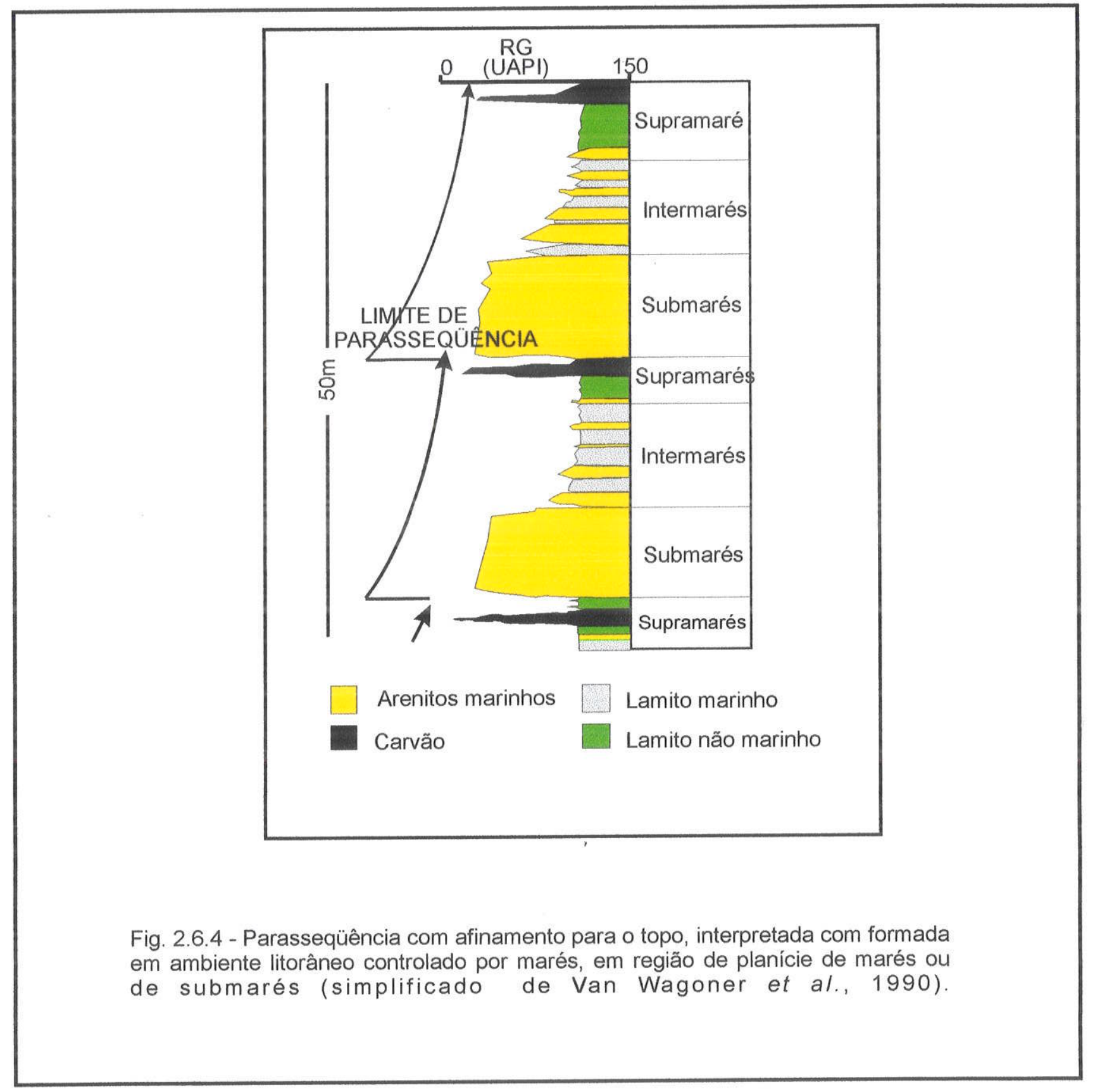




\section{5- Limite de parasseqüência}

Limite de parasseqüência é uma superfície planar, de extensão local ou regional, que revela pouca expressão topográfica mesmo em áreas afastadas, formada por uma inundação marinha ou por suas superfícies correlativas. A superfície de inundação é caracterizada por uma pequena erosão submarina ou uma zona de não-deposição, contendo um pequeno hiato. A quantidade de erosão submarina associada à superfície de inundação marinha varia da ordem de poucas polegadas a poucos metros. Alguns depósitos transgressivos residuais (transgressive lag) foram observados em testemunho ou afloramentos sobre a superfície de inundação marinha, não coincidentes com os limites de seqüências. Um depósito transgressivo residual corresponde a um depósito sedimentar, com espessura comumente inferior a $0,5 \mathrm{~m}$, de material relativamente grosso, composto de conchas, fragmentos de conchas, clastos de argila, nódulos calcários e/ou de seixos siliciclásticos. Este material deriva dos estratos abaixo, pela erosão da face de praia inferior (shoreface), durante a transgressão marinha e concentrado sob a forma de discreta camada no topo da superfície transgressiva, depositada no limite entre a plataforma interna e externa. Quando um depósito transgressivo residual ocorre sobre uma superfície de inundação marinha, ele é claramente derivado dos estratos abaixo. Entretanto, mais comumente, os depósitos residuais (lag) são encontrados sobre uma superfície de inundação marinha que coincide com o limite de seqüência. Neste caso, os depósitos residuais não possuem uma clara afinidade com os depósitos inferiores.

São descritos quatro tipos de depósitos residuais, entretanto, somente o primeiro é considerado transgressivo: a) depósito discreto, irregularmente marcado por nódulos calcários cujos diâmetros são maiores que $2,5 \mathrm{~cm}$. O depósito residual assentado sobre uma superfície de inundação é interpretado como sendo coincidente com o limite da seqüência na base de um vale inciso ou em uma área interfluvial. Este depósito residual deriva de nódulos de calcrete ou caliche formados dentro de um horizonte de solo, durante a exposição subaérea, quando a plataforma esteve exposta (limite de seqüencia). A subseqüente transgressão remove relativamente fácil o solo e concentra os nódulos sobre a superfície transgressiva. Estes nódulos podem ser os únicos indicadores de que um horizonte de solo existiu, a menos que algum remanescente de paleosolo possa ser 
encontrado, preservado em alguma área deprimida sobre a plataforma afogada; b) é gerado por intenso retrabalhamento provocado pela ação de correntes, ondas ou mesmo por bioturbação de uma parasseqüência situada abaixo da superfície de inundação marinha $(\cong 1,5 \mathrm{~m})$, da qual são retiradas as partículas finas e concentradas as grossas. Este retrabalhamento diminui gradualmente, não exibindo uma superfície que separa os depósitos retrabalhados do restante da parasseqüência. O retrabalhamento é interpretado como formado em resposta a tempestades e à colonização normal da infauna, subseqüente à transgressão. Entretanto, somente ocorre após a progradação de uma significativa quantidade de sedimentos finos sobre a superfície de máxima inundação marinha. Comumente, este depósito residual forma-se sobre uma superfície de inundação marinha que é coincidente com um limite de seqüência, embora esta coincidência não seja obrigatória para o desenvolvimento do depósito residual; c) comumente reconhecido sobre uma superfície de inundação marinha, seguindo a elevação do nível do mar, após a deposição de quantidade apreciável de sedimento siliciclástico fino progradante sobre a plataforma, permitindo a acumulação de carbonatos orgânicos ou inorgânicos sobre a superfície de inundação. Carbonatos orgânicos ocorrem na forma de camadas constituídas por conchas dispostas em amplos corpos tabulares de espessura maior que $1,8 \mathrm{~m}$, depositados sobre a superfície transgressiva (Kidwell, 1989, apud Van Wagoner et al., 1990). Embora estas camadas constituidas de conchas sofram um processo de limpeza, com a retirada dos clastos mais finos pelo retrabalhamento por ondas de tempestade; elas representam uma população indigena da plataforma. Estas camadas não são derivadas da erosão de parasseqüências depositadas abaixo. Os sedimentos grossos foram acumulados durante uma lenta elevação do nivel do mar quando a plataforma externa foi coberta com águas rasas após a deposição do trato de sistema de mar baixo (TSMB). A agitação das ondas é suficiente para formar oólitos ou pisólitos e o influxo siliciclástico é mínimo; d) este é provavelmente o tipo mais comum de depósito residual (chamado lag de base de canal), encontrado sobre o limite de seqüência na base de um vale inciso. Ele se acumula durante a queda do nivel do mar e consiste de uma variedade de tipos de grãos, sendo mais comum os seixos arredondados de chert, de quartzo ou quartzitos, variando de finas lentes com espessura de um seixo até camadas com espessura métrica. 
Os limites de parasseqüência dentro de um arcaboço regional de limite de seqüência são as melhores superfícies para correlações locais de tempo e fácies, a partir de dados de perfis de poços ou testemunhos. Estas superfícies podem também ser usadas para elaboração de mapas paleogeográficos pelos sequintes motivos: a) os limites de parasseqüência são superfícies facilmente reconhecidas que separam camadas mais velhas de outras mais novas; b) os limites formam-se rapidamente, provavelmente durante centenas a milhares de anos, sendo portanto, marcadores de tempo úteis para cronoestratigrafia; c) os limites de parasseqüência também limitam assembléias de fácies geneticamente relacionadas, proporcionando um arcaboço essencial para interpretação e correlação de fácies em perfis de poços, dentro de uma seqüência; d) finalmente, elas comumente se estendem em uma ampla área, o que permite uma correlação local com dados de subsuperfície. Contudo, os limites de parasseqüência, usualmente, não podem, no geral, ser facilmente correlacionados em âmbito regional quando ocorre grande espaçamento entre os poços de controle. Por esta razão e devido a distribuição das parasseqüências ser muito sensivel ao suprimento sedimentar, os limites de parasseqüência não são boas superfícies para correlação regional de tempo e fácies.

\section{6- Interpretação dos mecanismos de deposição}

As parasseqüências de origem marinha-rasa formam-se quando a taxa de sedimentação em um delta, uma praia ou uma planície de maré é maior que a taxa de acomodação ao longo da linha de praia (shoreline). Os limites das parassequências são formados quando a taxa de suprimento sedimentar na linha de praia é menor que a taxa de acomodação. Sob esta condição, a linha de praia se retrai rapidamente e muito pouco sedimento marinho é preservado no registro estratigráfico. Comumente, uma superfície de inundação marinha somente indica que a taxa de acomodação excedeu a taxa de suprimentọ sedimentar. Três diferentes mecanismos podem gerar limites de parasseqüências: a) o rápido aumento da profundidade da água causado por compactação de argilas de pró-deltas em um lobo deltaico, seguindo a avulsão de um canal distributário (Frazie, 1967, apud Van Wagoner, 1990); b) uma rápida elevação do 
nivel do mar causada por uma subsidência ao longo de uma falha tectonicamente ativa; ou c) devido a elevação eustática (Van Wagoner, 1990).

\section{7-Conjunto de parasseqüências}

Um conjunto de parasseqüência é uma sucessão de parasseqüências, geneticamente relacionadas, formando um modelo distinto de empilhamento sedimentar, limitado por superfícies de inundação marinha maiores ou por suas superfícies correlativas. Em alguns casos, um ou ambos os limites de um conjunto de parasseqüências poderá corresponder a um limite de seqüência, como também poderá separar distintos modelos de empilhamento de parasseqüências ou coincidir com os tratos de sistema (Van Wagoner et al., 1990). Entretanto, os termos trato de sistema e conjuntos de parasseqüências nem sempre são sinônimos como, por exemplo, em áreas com alta subsidência e influxo sedimentar, onde mais de um conjunto de parasseqüências pode existir em um único trato de sistema (Posamentier e James, 1993).

Os conjuntos de parasseqüências são considerados por Myers e Milton (1998) como uma classe de unidades deposicional intermediária entre a parassequência e a seqüência. A superfície de máxima inundação marinha que limita o conjunto de parasseqüências pode formar um marco para correlação sub-regional. De modo geral, os conjuntos de parasseqüências apresentam características semelhantes às das parasseqüências, embora, suas espessuras possam ultrapassar $500 \mathrm{~m}$ e seu tempo de formação atingir até $10^{5}$ anos. Outra importante diferença em relação às parasseqüências é que, por ter maior espessura, podem ser detectadas através de métodos sísmicos (Van Wagoner et al., 1990). Os modelos de empilhamento das parasseqüências (Fig. 1.6.7), dentro de um conjunto de parasseqüências, podem ser: progradacionais, retrogradacionais ou agradacionais (Van Wagoner, 1985 apud Van Wagoner et al., 1990), dependendo da relação entre a taxa de deposição e a taxa de acomodação. Em um conjunto de parasseqüências progradacionais, sucessivamente, as parasseqüências mais jovens são depositadas cada vez mais para o interior da bacia, como resultado da taxa de deposição ser maior que a taxa de acomodação. Inversamente, em um conjunto de parasseqüências retrogradacionais, as parasseqüências mais jovens são depositadas sucessivamente em direção ao continente, devido a taxa de deposição ser menor que a 
CONJUNTO DE PARASSEQÜENCIA PROGRADACIONAL

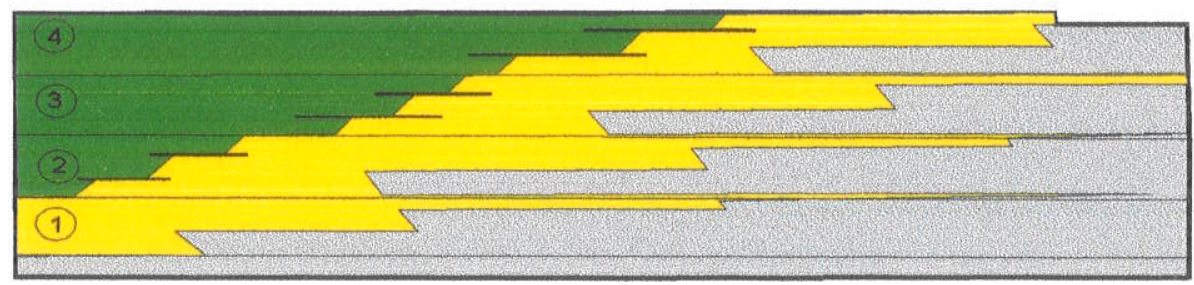

TAXA DE DEPOSIÇÃO > TAXA DE ACOMODAÇÃO PLANICIE COSTEIRA
ARENIOS ELAMITOS MARINHO RASO

(1) NÚMERO DA PARASSEQÜENCIA

CONJUNTO DE PARASSEQÜENCIA RETROGRADACIONAL

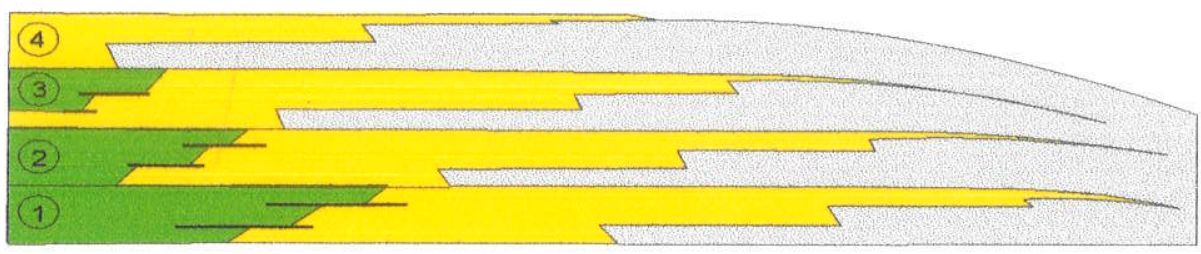

TAXA DE DEPOSIÇÃO < TAXA DE ACOMODAÇÃO

CONJUNTO DE PARASSEQÜÊNCIA AGRADACIONAL

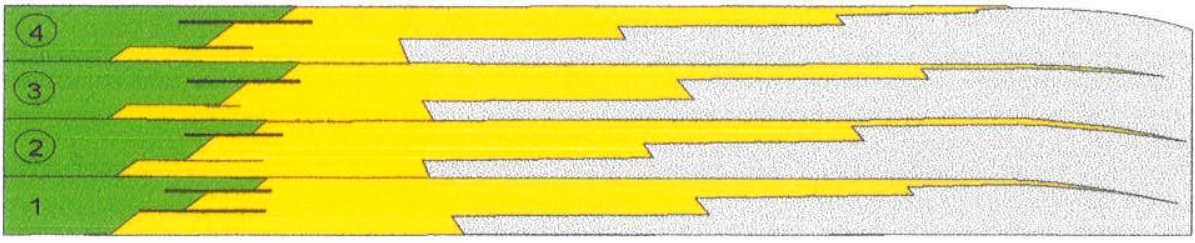

TAXA DE DEPOSIÇÃO = TAXA DE ACOMODAÇÃO

Fig. 1.6.7 - Modelo de empilhamento das parasseqüências dentro de conjuntos de parasseqüências (Segundo Van Wagoner et al. 1990). 
taxa de acomodação. Embora haja a progradação de cada parasseqüência individualmente, o conjunto de parasseqüências tende a um aprofundamento em um modelo transgressivo. Em um conjunto de parasseqüencias agradacionais, parasseqüências mais jovens são depositadas sucessivamente, empilhadas uma sobre a outra, sem deslocamento considerável em direção ao continente ou à bacia, devido ao equilíbrio entre a taxa de acomodação e a taxa de deposição (Van Wagoner et al., 1990).

Além de serem os elementos formadores das seqüências, as parasseqüências e os conjuntos de parasseqüências possibilitam um avanço nas correlações locais ou eventualmente regionais, como mostrado abaixo. Estas correlações resultam em produtos significativamente diferentes daqueles obtidos através da correlação litoestratigráfica convencional, com base em formações, arenitos de topo de formação ou intervalos de argilitos, como ilustrado na Figura 2.6.7. Nessa figura, mostra-se um conjunto de parasseqüências, com padrão progradacional, construida usando como datum o limite do conjunto de parasseqüências. As rochas que representam deposição em planície costeira e plataforma proximal, formam um padrão de parasseqüência cada vez mais jovem para cima e em direção da bacia. Já a correlação litoestratigráfica (Figura 2.6.7) foi realizada a partir de um datum formado pelo topo dos arenitos de origem marinha, por ser o limite mais eminente em SP e raios gama; e por proporcionar uma resposta similar à resistividade em cada perfil, visto que as fácies, porosidade e fluidos de cada corpo de arenito são similares (Van Wagoner et al., 1990).

As correlações feitas a partir de um datum como, por exemplo, as superfícies limitantes de conjuntos de parasseqüências, que têm valor cronoestratigráfico (chamadas de correlações cronoestratigráficas), ao contrário da correlação litológica, fornecem elementos para uma reconstrução paleogeográfica mais precisa.

\section{8- Seqüência}

No sentido em que se aplica na Estratigrafia de Seqüências, este termo foi inicialmente definido por Mitchum (1977) como uma sucessão relativamente concordante de estratos geneticamente relacionados, limitados por inconformidades ou por suas conformidades correlativas. Para esse autor, inconformidade é uma superfície de erosão ou não deposição, que separa estratos mais novos de estratos mais antigos e representa 


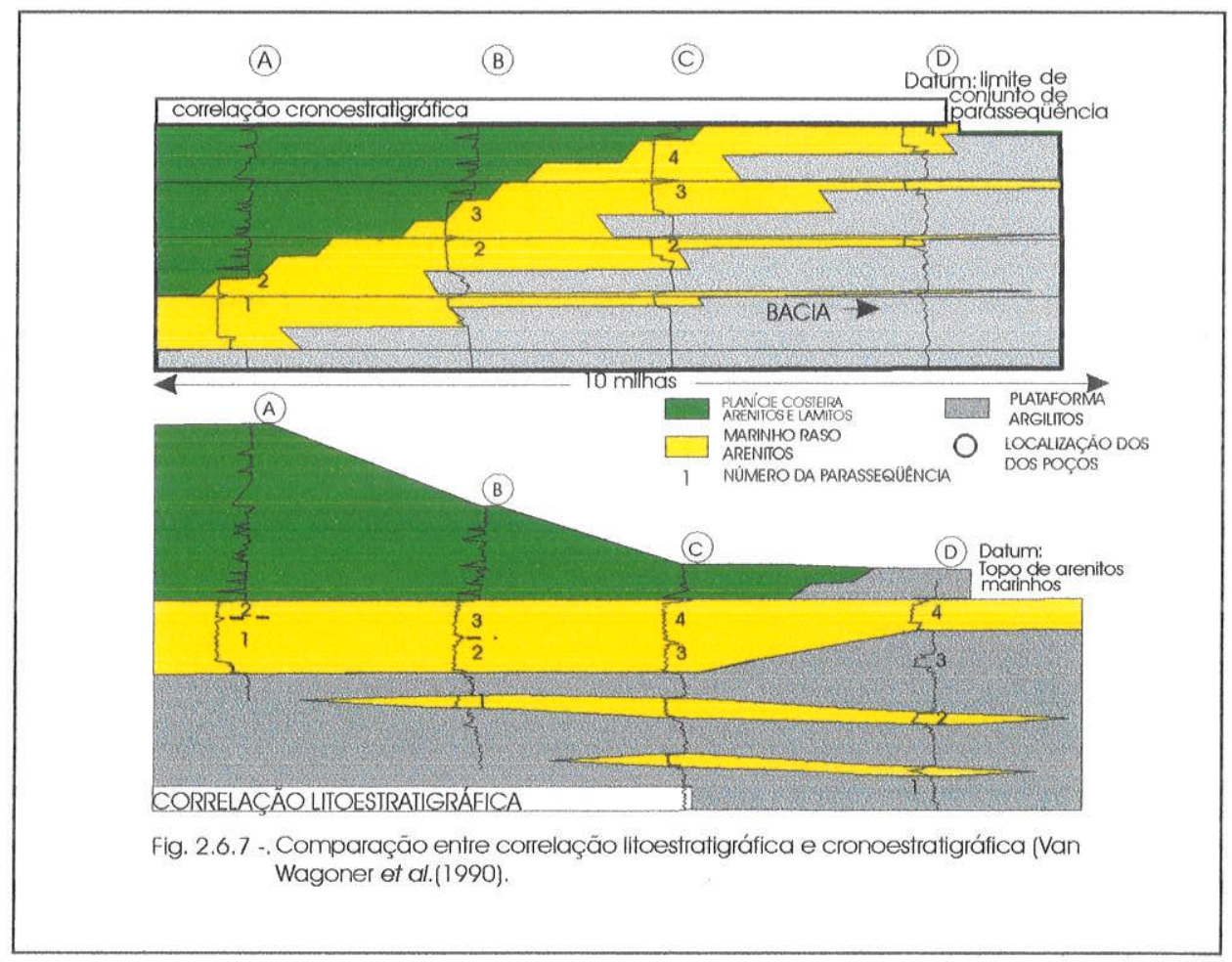


um hiato significativo, desta forma englobando equivocadamente os hiatos no interior da bacia e os intervalos de condensação marinha. Van Wagoner et al., (1988) redefiniram o conceito de inconformidade, como uma superficie que separa estratos mais novos de estratos mais antigos, ao longo da qual há evidência de erosão subaérea com truncamento (e em algumas áreas, erosão submarina correlativa) ou exposição subaérea com indicação de um significativo hiato. Desta forma, as inconformidades subaéreas de margem de bacia foram distingüidas dos hiatos de interior de bacia.

Myers e Milton (1998) levantam algumas questões em relação à definição de seqüência sensu Mitchum (1977). Para eles, a definição é generalizada e não especifica a escala ou duração da seqüência, nem sugere algum mecanismo particular como causador das inconformidades. Myers e Milton (op. cit.) questionam também a reformulação de Wagoner et al., (1988) da definição de inconformidades (acima citada), em relação ao termo significativo. Falta a indicação de qual magnitude de descontinuidade é significativa.

No registro sedimentar, são reconhecidos dois tipos de seqüencias, denominadas de seqüência tipo 1 e tipo 2. A sequência tipo 1 é limitada abaixo pelo denominado limite de sequeencia tipo 1 e acima por um limite tipo 1 ou tipo 2. A discordância tipo 1 está associada a exposição subaérea, erosão e incisão da plataforma, associada ao rejuvenescimento fluvial, deslocamento abrupto do onlap costeiro e migração de fácies em direção à bacia, acompanhada da deposição de uma cunha clástica nas porções distais da bacia. Como resultado da mudança de fácies em direção a bacia, rochas não-marinhas ou marinhas rasas são depositadas diretamente sobre rochas de origem marinha profunda. Este tipo de limite de seqüência é interpretado como formado quando a taxa de queda eustática excede a taxa de subsidência da bacia, junto a quebra da linha de praia deposicional, resultante de uma acentuada queda relativa do nível do mar (Van Wagoner et al., 1988). A seqüência tipo 2 é limitada abaixo por um limite de seqüência tipo 2 e acima por um limite tipo 1 ou tipo 2. A discordância tipo 2 está associada a exposição parcial da plataforma, entretanto, não são observadas incisões. Este tipo de limite de seqüência é interpretado como formado quando as taxas de rebaixamento do nivel do mar são menores relativamente e a mudança do onlap costeiro não é brusca.

As seqüências podem ser divididas em tratos de sistema, com base em critérios que incluem os tipos de superfície limitantes, além da distribuição e posição dos conjuntos de parasseqüências dentro da seqüência. $O$ termo trato de sistema foi inicialmente Lima Filho, 1998 - Programa de Pós-Graduação em Geologia Sedimentar 
definido por Brown e Fisher (1977 apud, Van Wagoner et al., 1988) para se referir a sistemas deposicionais interconectados. Os tratos de sistema podem também ser caracterizados pelas associações de fácies e por sua geometria (Van Wagoner et al., 1988; Posamentier et al., 1988; Posamentier e Vail, 1988).

Van Wagoner et al., (1988) usam o termo trato de sistema para designar três divisões dentro de cada seqüência: trato de sistema de mar baixo (TSMB), trato de sistema transgressivo (TST) e trato de sistema de mar alto (TSMB) na seqüências tipo 1. Na seqüência tipo 2 são reconhecidos os tratos de sistema de margem de plataforma (TSMP), trato de sistema transgressivo (TST) e trato de sistema de mar alto (TSMA). Portanto, a diferença na divisão dos tratos de sistema entre os dois tipos de seqüência se situa, grosso modo, apenas nos níveis de mar mais baixo. Quando os depósitos relativos ao trato de sistema relacionado ao nivel de mar mais baixo estiver depositado sobre uma discordância tipo 1 será denominado de TSMB; quando estiver depositado sobre uma discordância tipo 2 será denominado de TSMP. Se o trato de sistema de mar baixo for depositado em uma bacia com quebra de plataforma este trato de sistema poderá ser dividido em três unidades separadas, não contemporâneas: leque de assoalho de bacia, leque de talude e cunha de mar baixo. São os sistemas deposicionais que ocorrem associados à formação de canyons, na borda da plataforma (Posamentier et al., 1988; Posamentier e Vail, 1988).

\section{9- Trato de sistema de mar alto (TSMA)}

O trato de sistema de mar alto (TSMA) é o trato de sistema que ocorre na porção superior das seqüências tipo 1 ou tipo 2 (Fig.1.6.9a). Ocorre, normalmente, com ampla distribuição sobre a plataforma e pode ser caracterizado por um ou mais conjuntos de parasseqüências agradacionais sucedidos por um ou mais conjuntos de parasseqüências progradacionais, com padrão geométrico de clinoforma. As parasseqüências dentro do TSMA apresentam suas terminações em onlap sobre o limite de seqüência, em direção ao continente, e em downlap sobre o topo de um trato de sistema transgressivo ou trato de sistema de mar baixo, em direção à bacia (Van Wagoner et al., 1988). O TSMA é definido como o intervalo que começa em alguma região da curva depois do ponto de inflexão $\mathrm{R} e$ 


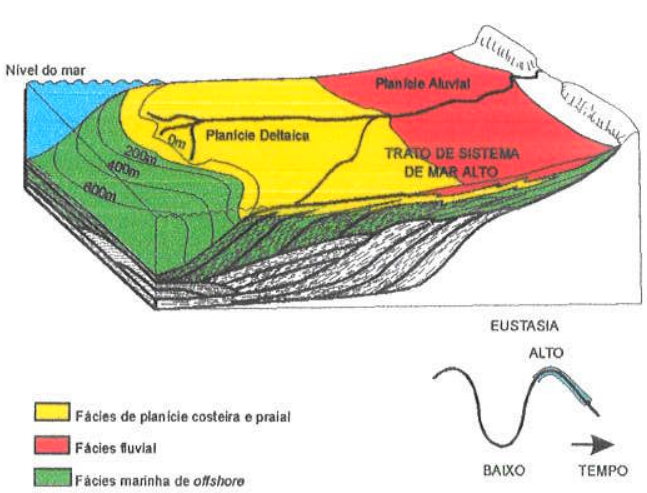

Fig. e- Trato de sistema de mar alto II

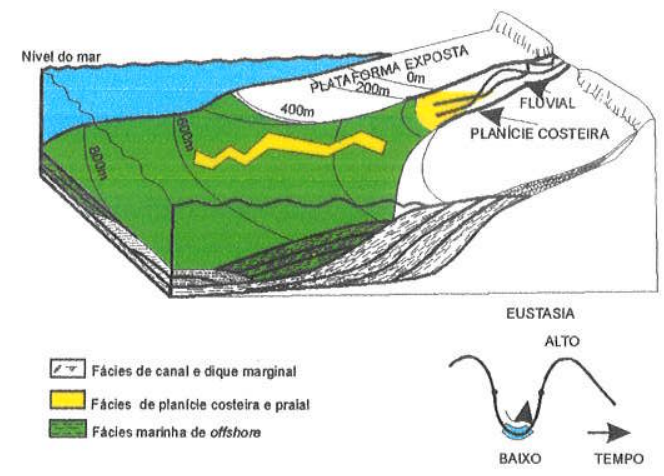

Fig. C-Trato de sistema de mar baixo (leque de talude)
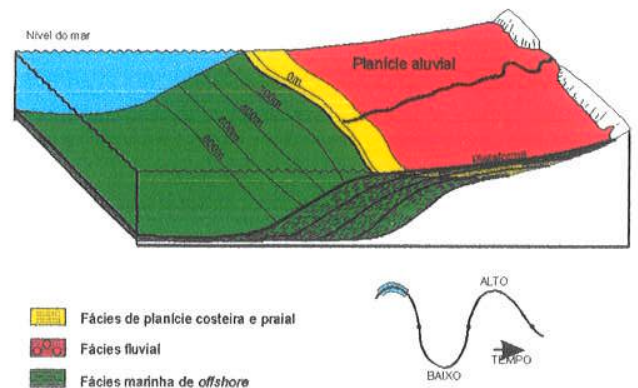

Fig.a - Trato de sistema de mar alto I

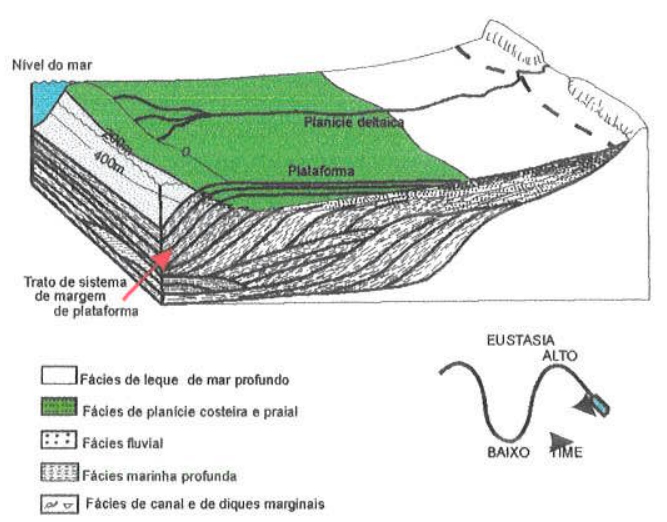

Fig. $\mathrm{f}$ - Trato de sistema de margem de plataforma

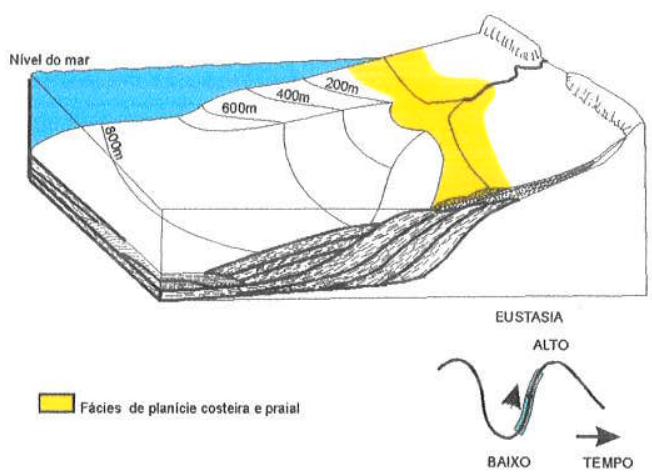

Fig. d - Trato de sistema transgressivo

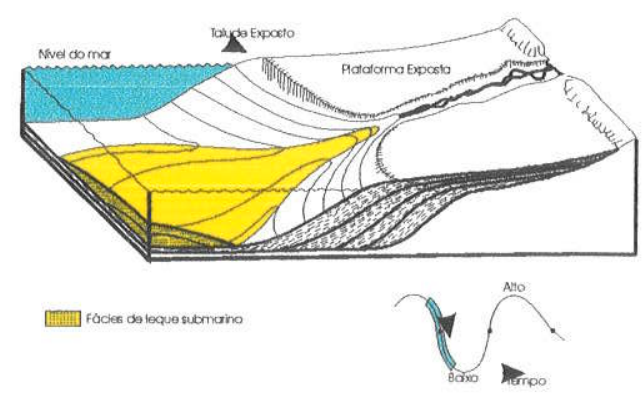

Fig.b - Trato de sistema de mar baixo (Leque de assoalho de bacia)

Fig. 1.6.9 - Modelo de tratos de sistemas e posições relativas do nível do mar com as respectivas fácies (Segundo Van Wagoner et al., 1988). 
finaliza antes do ponto de inflexão F (Fig. 2.6.9). Em resposta à lenta e gradual elevação do nivel relativo do mar, depois do ponto $R$ (com a diminuição da taxa de elevação do nivel do mar), a linha de praia, que sofria uma transgressão, pode começar a sofrer agora uma regressão, dando início a deposição desse trato de sistema. $O$ início deste evento depende também da variação do suprimento sedimentar. Contudo, como foi dito acima, ocorre geralmente em algum lugar da curva depois do ponto de inflexão $R$ e antes que o pico eustático seja atingido (Posamentier et al., 1988). Isto significa que o TSMA é depositado durante o período que compreende a parte final da elevação eustática, o periodo em que o nivel do mar permanece estável (eustatic stillstand) e a parte inicial do rebaixamento eustático. A base deste trato de sistema é normalmente associada a uma superfície de donwlap ou a seções condensadas (Loutit et al., 1988); $O$ topo deste trato de sistema é associado a uma deposição fluvial ampla, a qual começa algum tempo depois que o pico foi alcançado. O limite superior de um TSMA é caracterizado por uma inconformidade tipo 1 ou tipo 2 (Posamentier et al., 1988).

\subsection{0 - Trato de sistema de mar baixo (TSMB)}

O trato de sistema de mar baixo (TSMB) é depositado durante o intervalo caracterizado por uma relativa queda do nível do mar e subseqüente lenta elevação relativa do nível do mar. Se o TSMB for depositado em uma bacia com uma discreta margem de plataforma, este trato pode ser dividido em dois membros separados, não contemporâneos, denominados leque de nível de mar baixo (lowstand fan) ou leque de assoalho de bacia (basin floor fan) (Fig.1.6.9.b), seguido pela cunha de nível de mar baixo (lowstand wedge) (Fig.1.6.9.c). O leque de nível de mar baixo é dominado por leques submarinos formados pelos sedimentos que sobrepassam (bypass) a plataforma, através dos vales incisos ativos. A subseqüente cunha de nível de mar baixo é dominada por sedimentos finos, formando depósitos no talude em forma de cunha, contemporâneos aos depósitos que estão ocorrendo preenchendo os vales incisos. A subseqüente cunha de nível de mar baixo é dominada por sedimentos finos, formados por depósitos no talude em forma de cunha, contemporâneos aos depósitos que estão ocorrendo preenchedo os vales incisos. Neste trato de sistema há o deslocamento da linha de costa até a borda da plataforma continental, com o conseqüente aumento da atuação dos sistemas fluviais, 


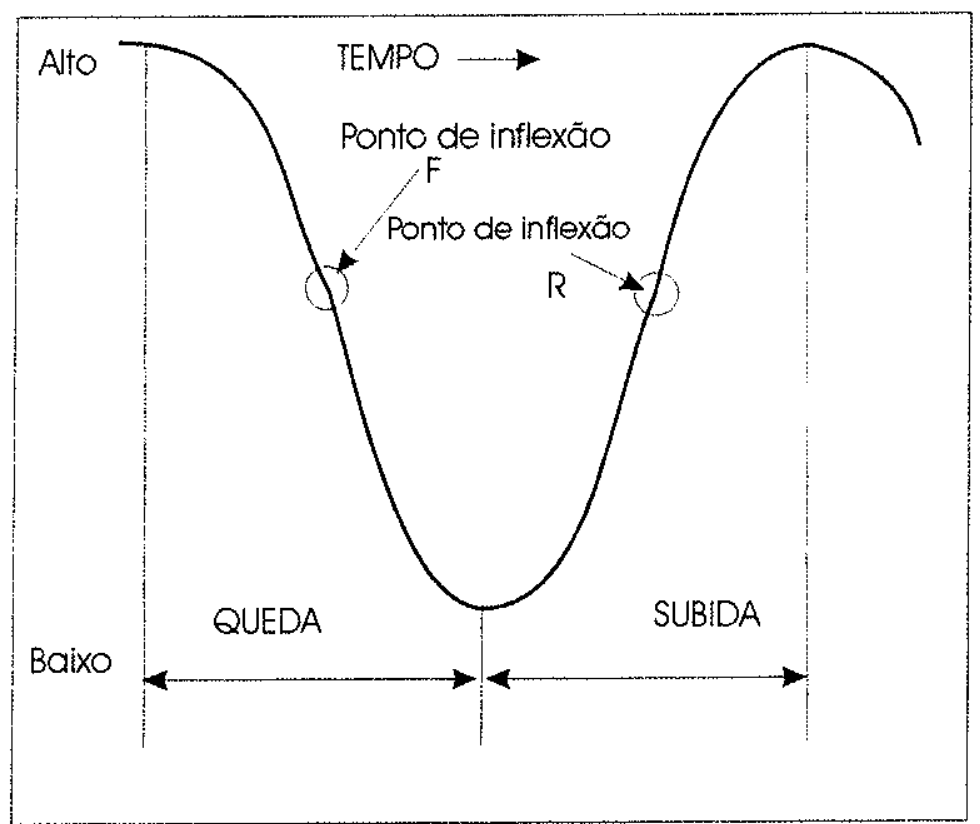

Fig. 2.6.9 - Elementos de mudança eustática (Posamentier et al., 1988). 
que por sua vez depositam cunhas de sedimentos flúvios-deltaicos na plataforma. Posteriormente, a linha de costa cai abaixo da borda da plataforma; ocorrendo erosão subaérea e incisão na plataforma pelo rejuvenescimento de canais fluviais na plataforma, além de escavações de canyons submarinos, desenvolvendo-se assim a discordância tipo 1. Os sistemas deposicionais envolvidos são os leques de assoalho oceânico e os leques de talude, constituidos por depósitos turbidíticos que repousam sobre o limite de seqüência (Posamentier et al., 1988; Posamentier e Vail, 1988; Van Wagoner et al., 1988).

\subsection{1- Trato de sistema transgressivo (TST)}

Para Van Wagoner et al. (1988), o TST (Fig. 1.6.9.d) é o trato de sistema que ocorre na posição mediana de uma seqüência tipo 1 ou tipo 2. Ela é caracterizada por um ou mais conjuntos de parasseqüências retrogradacionais. A base do TST é uma superfície transgressiva no topo do trato de sistema de mar baixo (TSMB) ou no topo do trato de sistema de margem de plataforma (TSMP). As parasseqüências do TST possuem uma terminação em onlap sobre a superfície transgressiva em direção à bacia. $O$ topo de um TST é uma superfície de downlap. A superficie de downlap é uma superfície de inundação marinha, na qual verifica-se a mudança do padrão de empithamento dos conjuntos de parasseqüência, passando de retrogradacional para agradacional, formando assim a superficie de máxima inundação marinha (SIM). A seção condensada ocorre amplamente entre O TST e O TSMA (Fig. 3.6.9), e consiste de uma fina camada de origem marinha, formada por sedimentos pelárgicos ou hemipelárgicos depositados em taxas muito lentas (Loutit et al., 1988).

O TSMP é uma unidade estratigráfica regressiva caracterizada por um modelo de empilhamento das parasseqüências de caráter progradacional e agradacional (Posamentier et al., 1988), que se desenvolve no flanco da segunda descida da curva sinusoidal, após o ponto de inflexão, num contexto de suave queda eustática (Van Wagoner et al., 1988) como mostrado na Fig. (Fig. 1.6.9.f). Este é o trato de sistema inferior, associado a um limite de seqüência tipo 2, cuja expressão sísmica mostra um conjunto de onlap direcionado para o continente e os downlap para o interior da bacia. Normalmente, recobre o trato de sistema de mar alto II (Fig. 1.6.9e). O TSMP deposita-se a partir da porção média da plataforma externa e é limitado por uma abrupta mudança de 


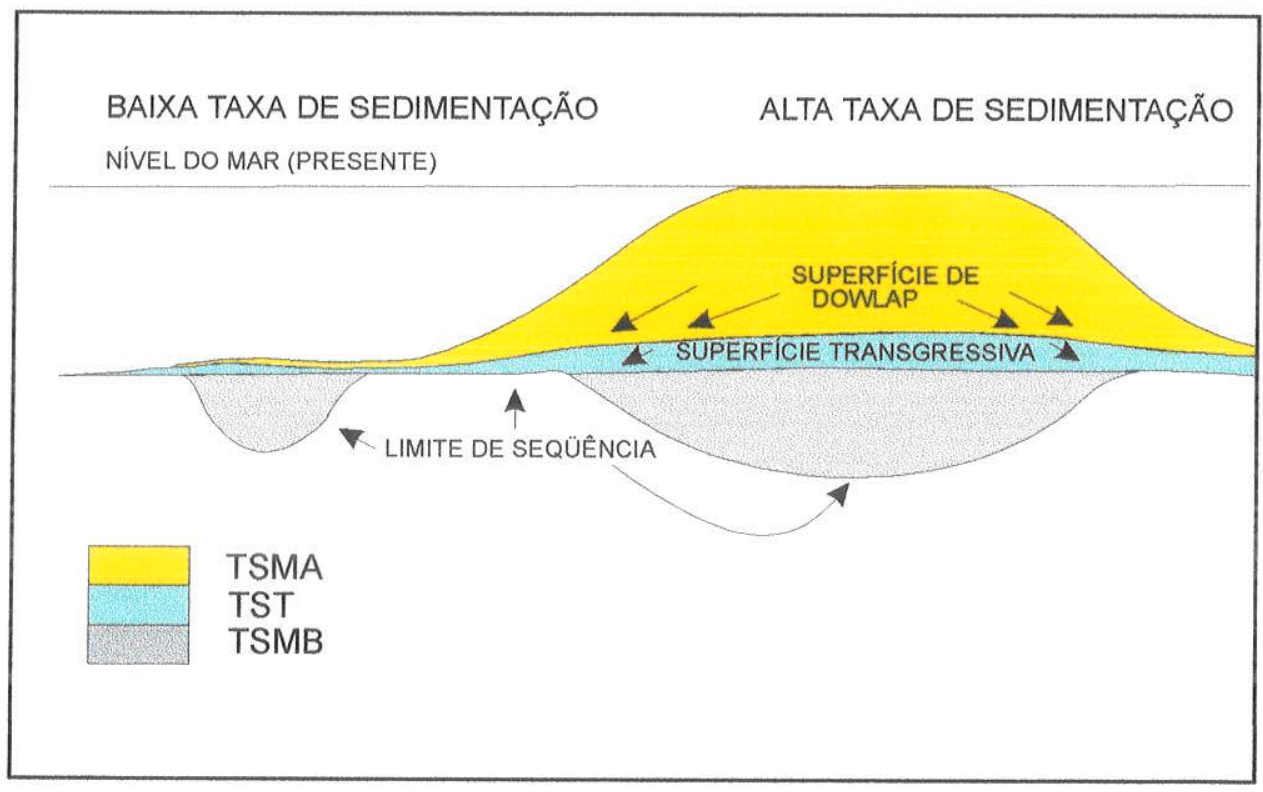

Fig. 3.6.9 - O limite de seqüência, superfície de downlap e superfície transgressiva podem ser separadas por considerável espessura de sedimentos em área com alta taxa de sedimentação, mas podem ser praticamente coincidentes em áreas com baixa taxa (Loutit et al.,1988). 
fácies, devido ao deslocamento do onlap costeiro para essa porção da plataforma. Ela fica então parcialmente descoberta, sofrendo pouca erosão ou mesmo não sendo erodida, gerando assim a discordância tipo 2, São comuns os sistemas deposicionais deltaicos, de plataforma e de talude (Posamentier e Vail, 1988). 


\section{7 - Estratigrafia de Seqüências em bacias intracratônicas}

A aplicação dos conceitos da Estratigrafia de Seqüências em bacias intracratônicas ainda é feita incipientemente, apesar do aumento representativo no número de artigos publicados nos último anos, inclusive no Brasil. Em um caso clássico de aplicação destes novos conceitos, na Bacia de Amadeus, Austrália, observa-se que apesar da aquisição de dados sísmicos de alta qualidade, as seçōes sísmicas não se mostram apropriadas a análise estratigráfica de seqüências deposicionais, pelo menos como sugerido originalmente pelo grupo da Exxon. Ajustes tornam-se necessários na elaboração de um arcabouço crono-estratigráfico para este tipo de bacia (Lindsay et at., 1993).

As diferenças originaram-se principalmente devido as baixas taxas de subsidência verificadas em bacias intracratônicas, baixo (ou mesmo ausência) talude deposicional e pequena profundidade da lâmina d'água, resultando conjuntamente na diminuição da acomodação sedimentar, em relação ao que se verifica em bacias de margem passiva. Assim, as seqüências ficam comprimidas verticalmente e as inconformidades erosionais são geralmente diminuídas. Devido a pouca inclinação do talude deposicional as terminações sísmicas são raramente evidentes e os depósitos comumente não mostram geometrias progradacionais. Logo, muitas parasseqüências se situam próximas ou abaixo do limite da resolução sísmica e, como conseqüência, os limites de seqüências e os tratos de sistemas geralmente só podem ser identificados pelas discontinuidades de fácies, hiatos bioestratigráficos e superfícies de erosão (subaérea e marinha) regional. Os depósitos de mar baixo são pobremente desenvolvidos, os vales incisos possuem distribuição areal restrita e muitas seqüências consistem de empilhamento de depósitos transgressivos e de mar alto, separados por inconformidades (unconformities) ou paraconformidades.

A subsidência e eustasia são as principais variáveis que controlam a distribuição e a geometria das seqüências em bacias intracratônicas. Eustasia, por definição, comum a todas as bacias, enquanto a subsidência ocorre em resposta aos eventos tectônicos, de proporção cratônica, o que resulta em eventos quase sincrônicos em bacias próximas (Lindsay et at., 1993). 


\section{1 - As Seqüências do Permo-Pensilvaniano da Bacia do Parnaíba}

O primeiro trabalho enfocando os conceitos de Estratigrafia de Seqüência na Bacia do Parnaiba foi realizado por Della Fávera (1990), um marco neste tipo de abordagem. Della Fávera (op. cit.) definiu três seqüências deposicionais: a Seqüência Devoniana, a Seqüência Devoniano-Mississipiana e a Seqüência Mississipiana.

Constituem-se em importantes referências outras duas tese recentemente apresentadas, cujos trabalhos mostraram-se também pioneiros na aplicação dos novos conceitos estratigráficos em bacias intracratônicas (Silva, 1996 e Becker, 1997). O primeiro versando sobre a ciclicidade sedimentar e sua influência no controle da distribuição de conodontes, fusulinídeos e palinomorfos no Pensilvaniano da Bacia do Amazonas. O segundo, na caracterização das seqüências do Permo-Carbonifero da Bacia do Solimões. Em ambos foram abordadas sucessões evaporiticas, em contexto similar ao encontrado na Sequêencia Permo-Pensilvaniana da Bacia do Parnaíba.

$\mathrm{Na}$ presente tese o estudo foi separado em duas partes: a primeira referente a aplicação dos conceitos da Estratigrafia de Seqüências em seções colunares isoladamente e em seções estratigráficas de afloramentos da Seqüência PermoPensilvaniana, principalmente da Formação Piauí; enquanto a segunda, envolve seções estratigráficas montadas a partir de dados de subsuperfície, como perfis compostos e testemunhos de sondagens, englobando as formações Piauí, Pedra de Fogo e Motuca, num contexto de bacia evaporítica.

No que tange a porção aflorante as sucessões sedimentares foram estudadas segundo duas óticas: 1) na busca de elementos que mostrassem os limites de seqüências a partir da interpretação e distribuição espacial dos sistemas deposicionais, como também através da análise da variação dos padrões de empithamento das parasseqüências (conjuntos de parasseqüências); 2) na conjunção dos dados acima levantados com os obtidos a partir do Gráfico de Fischer.

A segunda abordagem, relativa aos dados de subsuperfície, consistiu na elaboração de um modelo de bacia evaporítica que sugerisse a localização de possiveis superfícies erosivas, para posterior cruzamento com os dados obtidos com $\circ$ Gráfico de Fischer e identificação dos limites de seqüências.

Apresentam-se as interpretação da seção estratigráfica elaboradas com dados das seções colunares levantadas na $\mathrm{Br} .233$ (figuras 1.4.1, 2.4.1, 3.4.1, 4.4.1 e 5.4.1, 
respectivamente, das seção colunar da Baixa Fria, da Alegria e de Santa Rita); da seção colunar da Serra da Cruz (figuras 6.4.1, 7.4.1 e 8.4.1), no município de São Francisco, MA e da seção colunar da Ponta da Serra em Sambaíba, MA (Fig. 1.4.5).

\section{Seção estratigráfica da $\mathrm{Br} .233$}

Para a região compreendida entre os municipios de Altos e Beneditinos, $\mathrm{Pl}$, na borda leste da Bacia do Parnaíba, foi montado um arcabouço estratigráfico para a base da sucessão sedimentar da Seqüência Permo-Pensilvaniana e apresentado juntamente com os sistemas deposicionais interpretados (Fig.1.7.1).

As associações de fácies compreendendo as fácies AmM, AmgCa, AfPp, AmCa e LafMo da base seção colunar Alegria; as fácies AmCi, AfmPp. AfmCa, AfSL, da base seção colunar Baixa Fria e as fácies AmMMo e LPp seção colunar Santa Rita, são aqui interpretadas como os registros residuais pensilvanianos, contemporâneos à exposição subaérea da plataforma mississipiana. A associação de fácies acima citada é interpretada como depósitos de preenchimento de vales incisos, correspondente ao trato de sistemas de mar baixo (TSMB). Este trato de sistemas não aparece bem pronunciado em nenhum dos três perfis. O limite superior do TSMB é marcado por uma superfície transgressiva, normalmente marcada por rochas sedimentares de textura fina. Algumas vezes desenvolvem-se camadas de textura grossa, pouco espessas, denominadas de lag transgressivo, como na Alegria (Fig.3.4.1). No início da curva de variação do nível do mar o trato de sistemas transgressivo (TST) tem como característica um rápido crescimento na taxa de elevação do nível do mar, até o ponto de inflexão. Esta elevação propicia a deposição de lamitos e arenitos finos de plataforma sobre os depósitos proximais (p.e. fluviais, praiais e/ou de marés): A porção inicial do TST corresponde a associação de fácies AfLs, AfSW, AfPp, LRd, AfRd e FPp na seção colunar Alegria; pela associação AfSW, FPp e AfGc na seção colunar da Baixa Fria, e pela associação LPp, LW e AfW no seção colunar de Santa Rita. Estas associações foram interpretadas como depósitos de plataforma retrabalhada por ondas de tempestade. $\mathrm{Na}$ seção colunar Santa Rita os tempestitos dão lugar a depósitos siliciclásticos finos, representados pela fácies LWyLPpLs (figs. 4.4.1 e 5.4.1) interpretados como lobos de suspensão associados a sistemas deltaicos (Fig. 1.7.1). Na seção colunar da Baixa Fria os tempestitos são sucedidos por depósitos de praia que, provavelmente, representem um nível relativo de 
mar mais baixo (em uma ordem inferior) não marcado nos outros perfis. $\mathrm{Na}$ seção colunar Alegria o contexto mostra-se um pouco diferente, o TST apresenta-se com espessura anômala, superior a $40 \mathrm{~m}$, enquanto as espessuras dos perfis Santa Rita e Baixa Fria situam-se em torno de $20 \mathrm{~m}$. Provavelmente, corresponda a depósitos de pródelta e frente deltaica. Nesta seção colunar, não se encontram o limite superior do TST. A seção colunar Santa Rita é marcada pelo início do aparecimento de depósitos de marés, acima dos lamitos deltaicos, marcando o limite superior do TST. Situação idêntica a verificada na seção colunar Baixa Fria. Os registros do TSMA estão restritos aos perfis Santa Rita e Baixa Fria, ambos ocorrem como depósitos de marés na porção inferior. $\mathrm{Na}$ seção colunar Santa Rita, sobrepostos a estes depósitos, encontram-se arenitos interpretados como dunas eólicas costeiras. Esta situação foi prevista por Loutit et al., (1988) em regiões com diferentes taxas de sedimentação (Fig. 3.6.9).

A definição dos limites dos tratos de sistemas foi influenciada tanto pela interpretação dos sistemas deposicionais quanto pela análise do padrão de empilhamento de parasseqüências e conjuntos de parasseqüências. Na seção colunar Alegria há um aumento considerável no espaço de acomodação até a porção mediana da seção colunar, como mostram as setas na Figura 1.7.1. A partir deste ponto, correspondente ao ponto de inflexão, onde situam-se a superficie de máxima inundação marinha (SIM), as taxas de aumento mostram-se cada vez menores, refletindo a porção terminal do TST. Na seção colunar da Baixa Fria as parasseqüências mostram elevação de espessura somente até os primeiros $6 \mathrm{~m}$, quando a partir daí apresentam taxas de elevações sucessivamente menores. $\mathrm{Na}$ seção colunar Santa Rita esta relação não esta muito clara. A passagem do TST para o T.S.M.A é caracterizada pela presença dos depósitos de marés sobrepostos aos depósitos deltáicos, nos perfis Santa Rita e Baixa Fria. $\mathrm{Na}$ seção colunar Santa Rita, continuando o padrão de queda de nivel relativo (diminuição de espessuras das parasseqüências), os depósitos de marés dão lugar aos depósitos eólicos, na porção superior da seção colunar, ainda em T.S.M.A. 


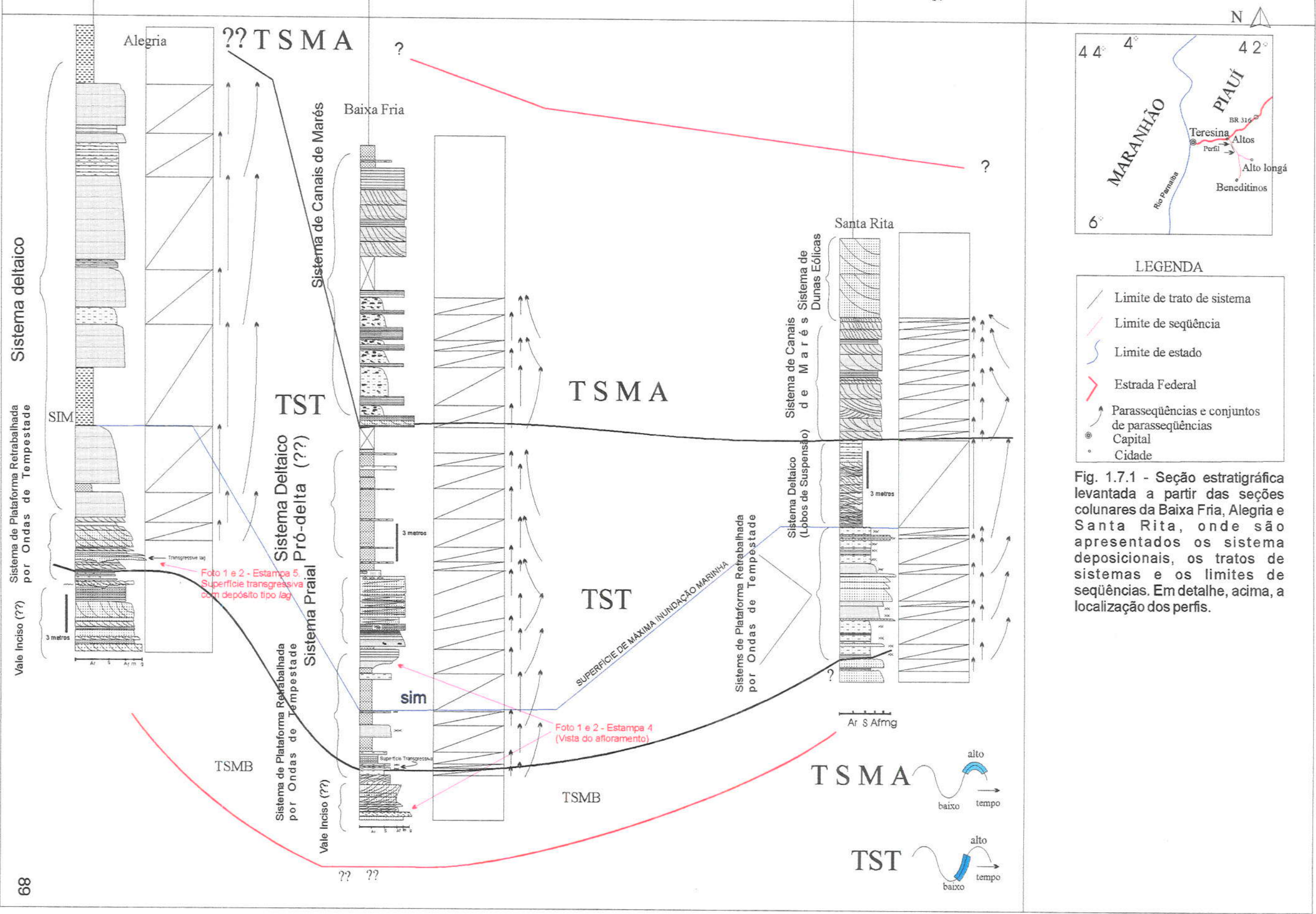




\section{Seção colunar Serra da Cruz}

Na porção central da borda leste da Bacia do Parnaíba, os estratos das formações Piauí, Pedra de Fogo e Motuca estão expostos em escarpas de tabuleiros que freqüentemente ultrapassam os $250 \mathrm{~m}$ de diferença de nível. No município de São Francisco, MA, encontram-se muitas exposições que se prestam a descrição de perfis contínuos como, por exemplo, na localidade denominada de Serra da Cruz. O levantamento $e$ interpretação dos perfis forneceram subsidios para construção do arcabouço estratigráfico da Seqüência Permo-Pensilvaniana em afloramentos da borda leste (Fig. 2.7.1).

O reconhecimento do tipo de contato que ocorre separando as formações Poti e Piauí é de extrema relevância na definição do limite de seqüência, se tipo 1 ou tipo 2.

Mesner \& Wooldridge (1964) consideram que há uma discordância angular suave entre estas formações.

Para Aguiar (1971), o contato Poti/Piauí é erosivo e angular nos bordos da bacia.

Andrade \& Daemon (1974) consideram como discordante o contato entre estas formações, o que pode ser observado tanto em superfície, quanto em subsuperfície, através da correlação de perfis elétricos. A origem desta discordância estaria relacionada a um suposto soerquimento do flanco sudoeste da bacia.

O contato entre a Formação Piauí e Poti é considerado nitidamente erosivo por Cruz et al. (1973). Não obstante, tecem algumas considerações sobre a natureza do contato evidenciado: 1) pela presença de um conglomerado basal, que contém seixos de quartzo, quartzito, fragmentos angulosos e achatados de folhelho e blocos de arenito silicificado, com até $50 \mathrm{~cm}$ de diâmetro. Outros depósitos conglomeráticos foram também encontrados dentro de níveis superiores desta seção da Formação Piauí até $150 \mathrm{~m}$ acima do contato; 2) por uma zona de oxidação com até $0,5 \mathrm{~m}$ de espessura (p.e. no furo 1-UR2-PI); 3) pelo contato do Membro Inferior da Formação Piauí com o Membro Inferior da Formação Poti, ou seja o contato de arenitos avermelhados grossos, friável, caulinizados, com estratificação cruzada (Membro Inferior da Formação Piauí), sobre siltitos e arenitos finos com estratificação plano-paralela (Membro Inferior da Formação Poti); 4) pelo contato do Membro Inferior da Formação Piauí sobre o Membro superior da Formação Poti, ou seja sobre pelitos. Cruz et al. (op. cit.) apontam a dificuldade em identificar o contato erosivo quando se dá entre arenitos, grosso modo, entretanto, as rochas da 


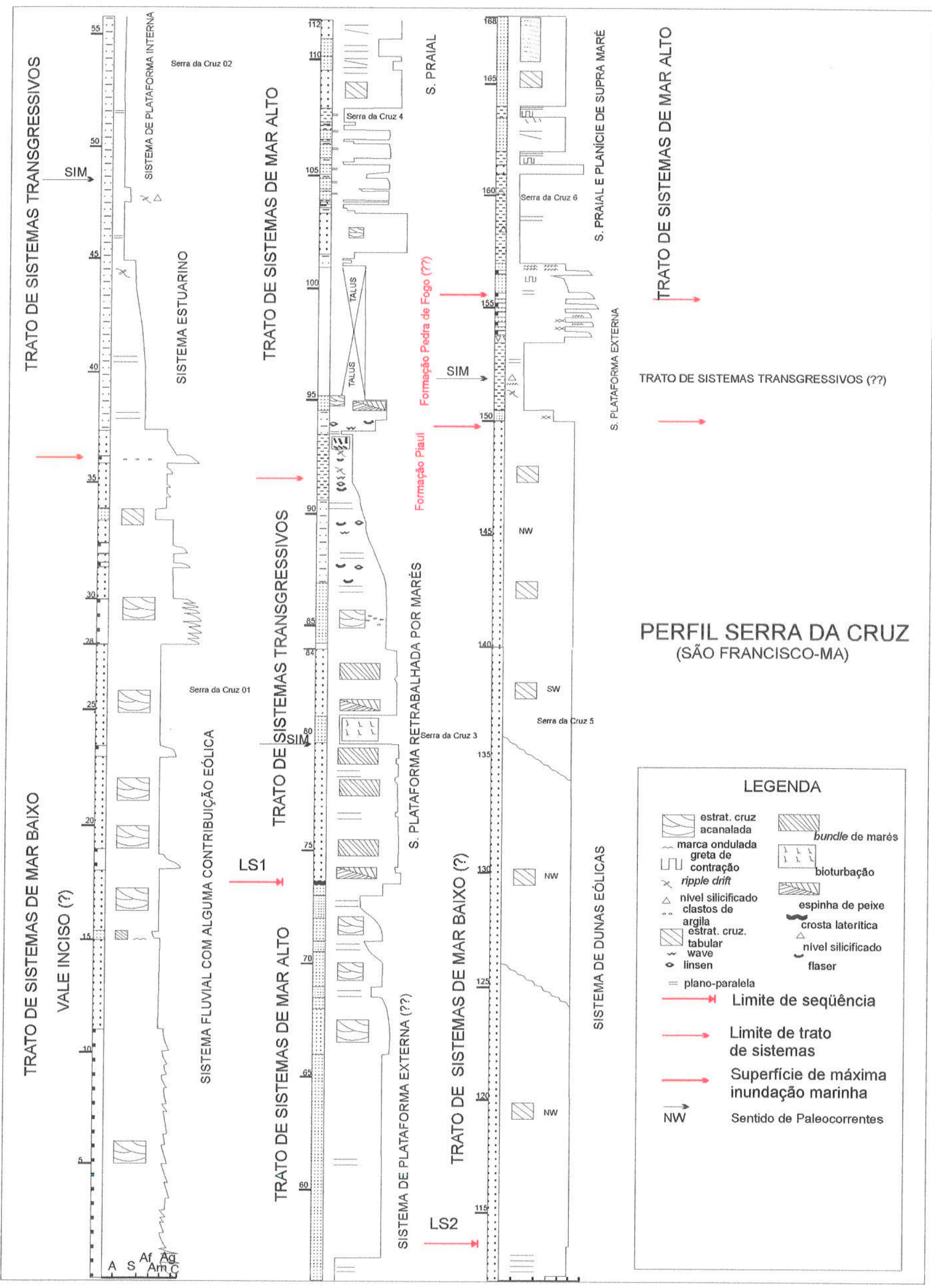

Fig. 2.7.1-Seção estratigráfica levantada na Serra da Cruz no município de São Francisco-MA, onde são mostrados os sistemas deposicionais, os tratos de sistemas e as seqüências deposicionais. 
Formação Poti apresentam uma tendência em exibir minerais formados em ambientes redutores, enquanto a Formação Plauí mostra ambientes de caráter deposicional oxidante. Quando as rochas da Formação Potí exibem cores avermelhadas, o limite, na falta de outras evidências, nem sempre aparece muito distinto (Cruz et al., 1973).

Uma vez admita a presença de uma discordância generalizada entre as formações Piaui e Potí, provavelmente associada a orogenia eo-herciniana que expôs subaéreamente a bacia, é concebida também, como tipo 1, a discordância que separa a Seqüência Mississipiana da Seqüência Permo-Pensilvaniana. O rebaixamento do nível do mar seria responsável pela instalação de incisões na plataforma mississipiana, geradas pelo aumento do gradiente fluvial, sob a forma de vales incisos.

$\mathrm{Na}$ porção inferior da seção colunar ocorrem arenitos de textura predominantemente média a grossa, as vezes conglomerática, interpretada como sistema fluvial. Os níveis mais grossos marcam os ciclos fluviais representando reativações do canal fluvial, como reflexo de quedas eustáticas ou originadas de eventos tectônicos.

Em analogia às parasseqüências, os ciclos fluviais também podem mostrar variações no padrão de criação do espaço de acomodação sedimentar. Diminuições progressivas da espessuras dos ciclos fluviais podem sugerir diminuição na taxa de queda relativa do nível do mar. Os ciclos fluviais da base da seção colunar da Cruz mostram diminuição progressiva de espessura para cima, pelo menos até os $35 \mathrm{~m}$ (Fig. 6.4.1). A base da seção colunar foi convencionada como zero.

Como anteriormente referido, O TSMB pode ocorrer como dois tratos de sistema diferenciados, não contemporâneos, representados por duas posições distintas na curva de variação relativa do nível do mar, denominados TSMB de Leques de Assoalho de Bacia e TSMB de Leques de Talude de Bacia (figuras 1.6.9b e 1.6.9c). No primeiro caso, representado pelo segmento que se estende desde um ponto situado subseqüente ao pico da porção superior da curva (após o TSMA), até um ponto situado antes da porção mais baixa da calha. O ponto de inflexão situa-se na porção mediana deste segmento (Fig. 1.6.9b). Na primeira metade da curva se verificam aumentos progressivos nas taxas de queda relativa do nível do mar, atingindo seu pico no ponto de inflexão. A partir deste ponto há uma redução, também progressiva, na queda da taxa do nível relativo do mar. $E$ neste contexto, de queda acentuada e depois de queda mais reduzida, que ocorre a formação de vales incisos e deposição de leques de assoalhos. 
Para melhor compreensão da relação entre o empilhamento do sistema fluvial no TSMB da base da Seqüência Permo-Pensilvaniana da bacia do Parnaiba e a curva de variação relativa do nível do mar será feita uma divisão esquemática nesta curva (Fig. 3.7.1). A diminuição progressiva das espessuras dos ciclos fluviais é explicada pela relação direta que existe entre a diminuição da taxa de queda do nível do mar, nesta porção da curva, e a conseqüente queda do nivel de base, que controla o sistema fluvial. A medida que o nível de base tende a cair com taxas cada vez menores, consequentemente, os ciclos fluviais vão responder com espessuras menores, proporcionais às taxas de queda eustáticas como mostra a Figura 3.7.1, na parte 1 da curva. No ponto mais baixo da curva, na calha, o nivel de base se estabiliza.

Entre as espessuras 35 e $50 \mathrm{~m}$ se verifica-se brusco afinamento textural. Uma camada de arenito conglomerático, com clastos de argila, que ocorrem a altura aproximada de $36 \mathrm{~m}$ é interpretada como o lag transgressivo que marca o início do TST (Figura 2.7.1). A base do corpo de folhelho mais espesso ( $49 \mathrm{~m}$ ) representa a maior taxa de elevação eustática, caracterizando a superfície de máxima inundação marinha (SIM). Em termos de sistemas deposicionais significa o afogamento fluvial e a retrogradação dos depósitos costeiros, sobrepostos por folhelhos e arenitos de plataforma. Da $56 \mathrm{~m}$ a $74 \mathrm{~m}$, as parasseqüências apresentam-se com diminuição de espessura para o topo, sugerindo a presença do TSMA. Este trato é finalizado abaixo de uma camada de arenito, com estratificação espinha de peixe, marcado pela presença de crosta laterítica. Inicia-se assim outro ciclo de TST o que caracteriza um limite de seqüências (seqüência 1/2). Neste trato há predominância de rochas arenosas na base e argilosas no porção superior, envolvendo plataforma retrabalhada por marés que sofreu afogamento. $O$ nivel relativo do mar torna a cair, como mostra o padrão das parasseqüências (Fig. 7.4.1), até exibir os depósitos de praia, representativos do TSMA. Nova queda relativa e o desenvolvimento de campos de dunas, camadas com mais de $35 \mathrm{~m}$ de espessura, marcam o limite de sequêencias e o início dos depósitos do TSMB (seqüência 2/3). Sobrepostos aos depósitos eólicos encontram-se siltitos retrabalhados por ondas de tempestade, cobertos por folhelhos, com níveis silicificados, concentrados na altura de $152 \mathrm{~m}$, a provável superficie de máxima inundação marinha. Acima, ainda num contexto de plataforma retrabalhada por ondas de tempestade ocorrem depósitos grossos com gretas de contração na porção superior. Inicia-se assim, na altura de $156 \mathrm{~m}$, o TSMA que mostra depósitos de praia intercalados com lamitos, portando gretas de contração. 


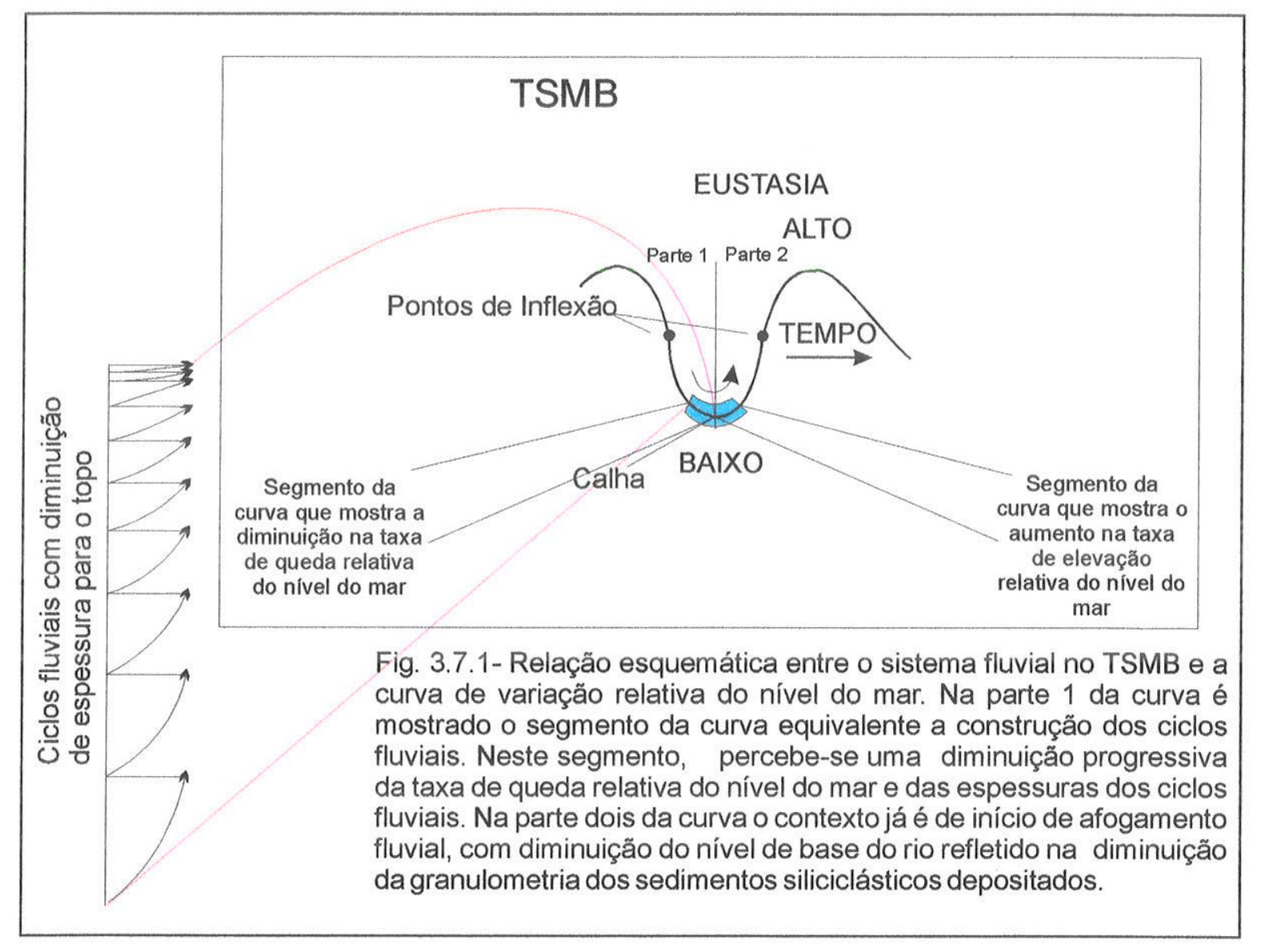




\section{Seção colunar da Ponta da Serra}

A porção superior da Seqüência Permo-Pensilvaniana tem como uma de suas características mais marcante, a predominância de rochas sedimentares pelíticas sobre as arenosas. Esta caraterística textural é refletida no relevo, que imprime às formações Pedra de Fogo e Motuca, principalmente a esta última, relevo pouco expressivo. Daí, a grande dificuldade no levantamento de perfis verticais. No município de Sambaíba, em frente a Fazenda Ponta da Serra, a Formação Motuca exibe um considerável relevo, protegida pelas escarpas da Formação Sambaiba, que a sobrepõe, e que permitiu o levantamento da melhor seção colunar dessa formação. Outra característica identificada nos afioramentos da porção centro-sul da bacia foi o grande número de falhas e fraturas, que mascara estruturas sedimentares primárias.

Foram interpretados os sistemas deposicionais fluvio-eólico-lacustre (Fig. 4.7.1), num padrão de afinamento para o topo. Na porção inferior da seção colunar identificamse mais de $7 \mathrm{~m}$ de arenito com estratificação cruzada de médio porte, tangencial na base, com laminação por fluxo e queda de grãos, interpretados como depósitos eólicos (fácies AmfCA, Fig.1.4.5). Sobrepostos, encontram-se intercalados por mais de $50 \mathrm{~m}$, as fácies de arenito/siltito com estratificação de baixo ângulo (plano-paralela?) e arenito fino a médio com estratificação cruzada acanalada, respectivamente, AfBa e AmfCa. Esta associação de fácies foi interpretada como sistema fluvial, com características intermediárias entre entrelaçado e meandrante, com depósitos de canais e de planície de inundação. Nos últimos $30 \mathrm{~m}$ da seção colunar a fração pelítica predomina, bastante bioturbada, com a presença de corpos arenosos interpretados como lobos de suspensão. Esta associação de fácies (LPp, AmmfPpB, AfmmBa, AfmfB e AfMols) é interpretada como um sistema fluvio-lacustre.

A aplicação da Estratigrafia de Seqüências em depósitos continentais, mais difícil que em depósitos marinhos/costeiros, requer um melhor controle espacial das sucessões estudadas. Controle este, difícil de ser obtido pela carência de afloramentos expressivos e pelo intenso tectonismo. Entretanto, em função do contexto e por comparação com a seção colunar de poços estudados, pode-se afirmar, preliminarmente, que esses depósitos correspondam a TSMB. A distribuição dos tratos de sistemas das unidades superiores será analisada mais profundamente a partir dos dados de sub-superfície. 


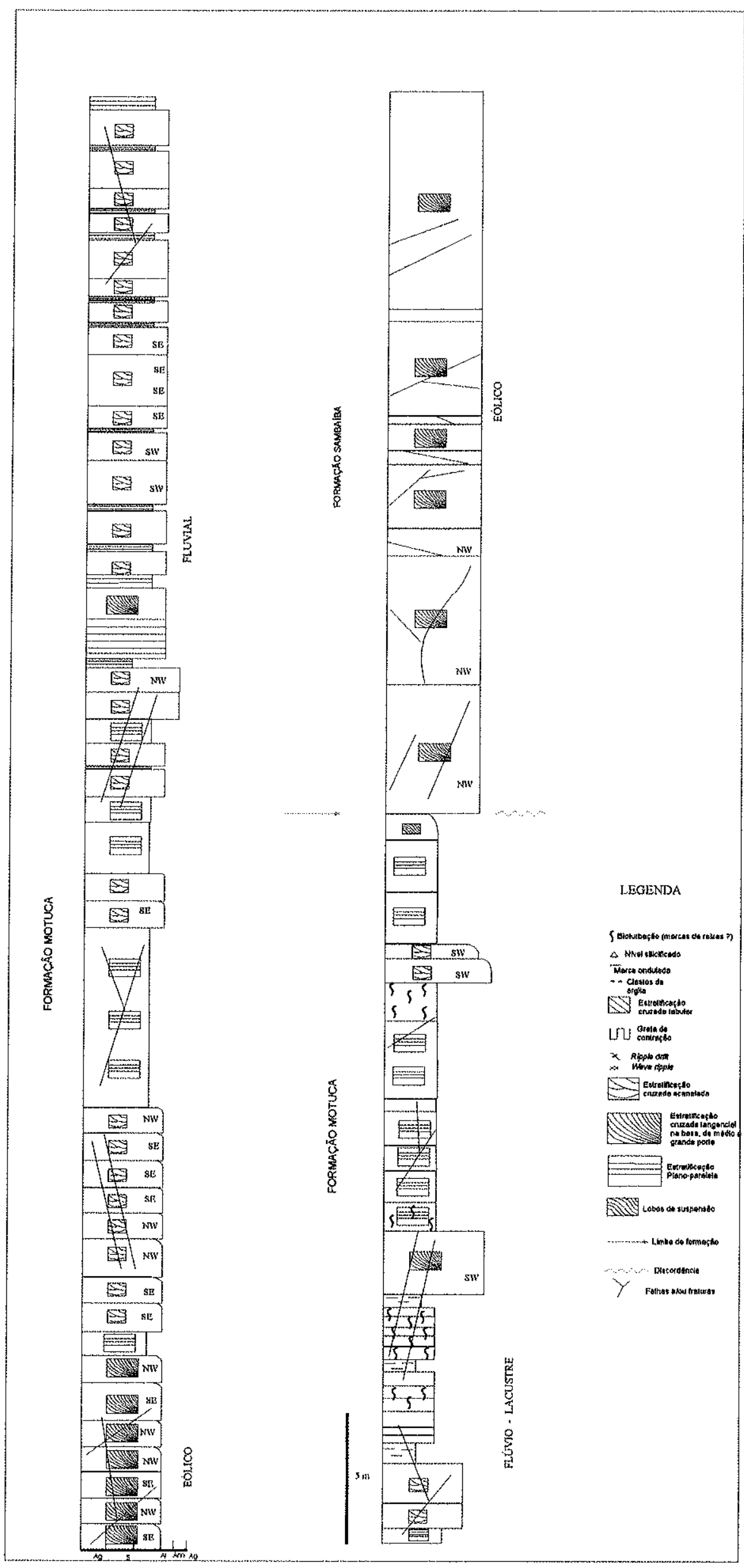

Fig. 4.7.1- Perfil levantado no município de Sambaíba-MA, na Fazenda Ponta de Serra, onde ocorrem boas exposições das formações Motuca e Sambaíba. As rochas da Formação Motuca são representadas por arenitos, siltitos e lamitos interpretados como depósitos flúvio-eólico-lacustre. 


\section{Seção Estratigráfica da Borda Leste}

Para a definição das seqüências deposicionais nesta seção, analisaram-se os perfis de raios gama com o objetivo de identificar os padröes de empilhamento, como também buscou-se correlacionar os limites previamente identificados nas seções colunares de superfície. Utilizou-se também os limites identificados a partir do Gráfico de Fischer, no poço 8 (Fig. 5.7.1), como referência. A identificação de recorrência de padrões cíclicos distintos, obtidas pela análise dos perfis de raios gama foi realizada segundo o padrão já identificado por Becker (1997), para a seção permo-pensilvaniana da Bacia de Solimões, correspondendo a três padrões de empilhamento, definidos segundo a posição dos folhelhos mais radioativos, denominados: simétrico, assimétrico transgressivo e assimétrico regressivo (Fig. 6.7.1).

Foram identificadas aqui cinco seqüências (no poço 8), quatro na seção colunar da Serra da Cruz e três no poço 9 . Como esses conjuntos estão inseridos na Seqüência Pensilvaniana, considerada como de $2^{a}$ ordem, foram hierarquicamente posicionados como seqüências de $3^{a}$ ordem (Fig. 5.7.1). A diferença do número de seqüências identificadas ao longo da seção, pode ser explicada pelo posicionamento da seção estratigráfica próxima a paleoborda leste. Pode, também, ser devido ao ângulo entre a direção SW-NE de um dos principais depocentros da bacia neste período e a seção estratigráfica N-S. Desta forma, estão sendo cortadas rochas mais continentais (de borda), na porção SE e rochas mais marinhas/evaporíticas (de interior da bacia) na porção NE.

De uma forma geral, a composição resultante da montagem da seção estratigráfica, a partir de perfis compostos de poços da Petrobrás e de seções colunares de afloramentos da borda leste, mostrou-se apropriada a elaboração de um arcabouço cronoestratigráfico para área em estudo. Apenas o poços 10 não forneceu dados suficientes, o perfil de raios gama foi apresentado em escala inadequada para ressaltar as argilosidades, fundamentais nesta abordagem. A análise de fácies dos testemunhos de sondagens (\#1 e \#2) permitiu a interpretação de sistemas deposicionais de lobos deltaico e dunas eólicas, respectivamente, dados insuficientes para participar da montagem do arcabouço.

A seqüência 1, na borda leste, apresenta-se como a porção inferior da Formação Piauí, posicionada acima da discordância tipo 1 aqui admitida. Sua espessura varia de 28 


\section{SEÇÃO ESTRATIGRÁFICA DA BORDA LESTE}

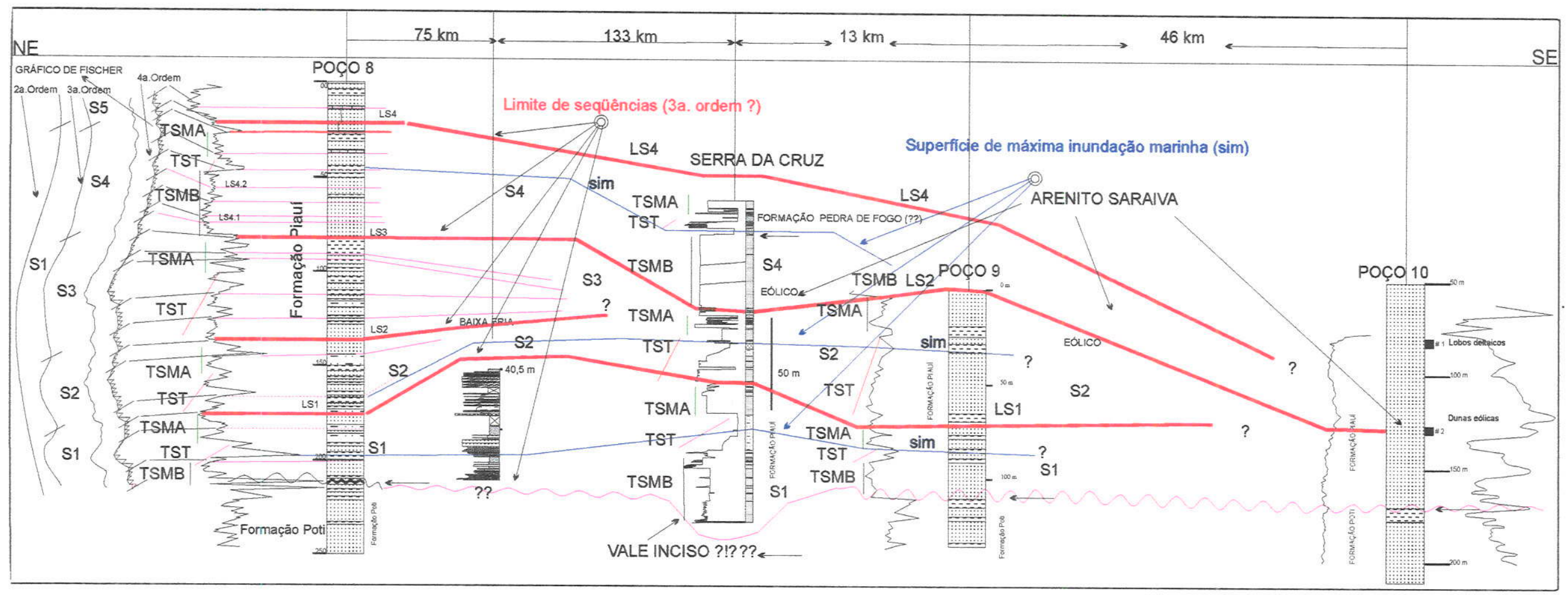

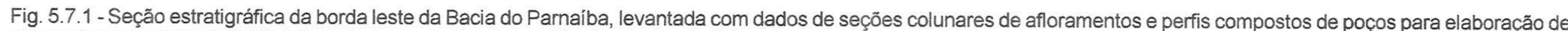

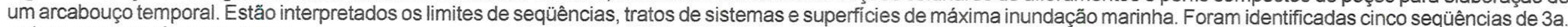
ordem e um possivel vale inciso. 
m no poço 8; $32 \mathrm{~m}$ no poço 9; e a $56 \mathrm{~m}$ na seção colunar da Serra da Cruz. Tal aumento de espessura pode ser explicado pela presença de vales incisos, comumente associados aos limites de seqüência tipo 1 (Fig. 5.7.1). É constituida por três tratos de sistemas, o TSMB, TST e TSMA. Na seção colunar da Serra da Cruz, o TSMB está bem caracterizado, representado por depósitos fluviais (Fig. 2.7.1), mostrando-se pouco expressivo em direção ao poço 8. O TST corresponde, inicialmente, ao afogamento do sistema fluvial, exibindo uma superfície de máxima inundação marinha (SIM) expressiva, perfeitamente correlacionável em todas as seções, exceto no poço 10. Compreende rochas interpretadas como depósitos de plataforma interna. O TSMA teve seus limites definidos principalmente pela diminuição das espessuras das parasseqüências, correspondendo, provavelmente, a depósitos de plataforma externa tendendo a região mais costeira.

A seqüência 2 apresenta-se bem definida nos poços 8 e 9 , como também na Serra da Cruz. Não foram identificados registros da TSMB, entretanto, o TST apresenta-se bem desenvolvido com maiores espessuras no poço 9 e na Serra da Cruz, correspondendo a depósitos de marés com progressivo aumento da espessura das parasseqüências. $O$ TSMA também ocorre expressivamente nos poços 8 e 9 . Não foi possível estender esta seqüência até o poço 10.

A seqüência 3 esta restrita ao poço 8 , não sendo identificada nas outras seções colunares da borda leste, entretanto, ocorre expressivamente em direção ao interior da bacia. Compreende um TST bem desenvolvido e um restrito TSMA.

Na Serra da Cruz a seqüência 4 inicia-se com depósitos eólicos de TSMB, sobrepostos por delgados depósitos areno-argilosos de plataforma retrabalhada por ondas de tempestade, interpretados como possível registro do TST. O TSMA corresponde a depósitos arenosos de praia, intercalados com lamitos com gretas de contração de provável planície de marés. No poço 8 o TSMB também corresponde a prováveis depósitos eólicos, o TST ocorre restritamente. O TSMA envolve uma sucessão cíclica de depósitos siliciclásticos e carbonatos, correlacionáveis aos carbonatos que ocorrem na regiāo de José de Freitas-PI (Mocambo, Contendas, Meruoca, Carimã, Vidalgo e Esperança), interpretados como plataformas carbonáticas e lagunas (Lima Filho, 1991a, 1991b). O comportamento cíclico, com raseamento para o topo, é evidenciado pela presença de gretas de contração na maioria das seções colunares carbonáticas levantadas (Fig. 7.7.1), sugerindo a presença de limites de seqüências de $4^{*}$ ordem. 


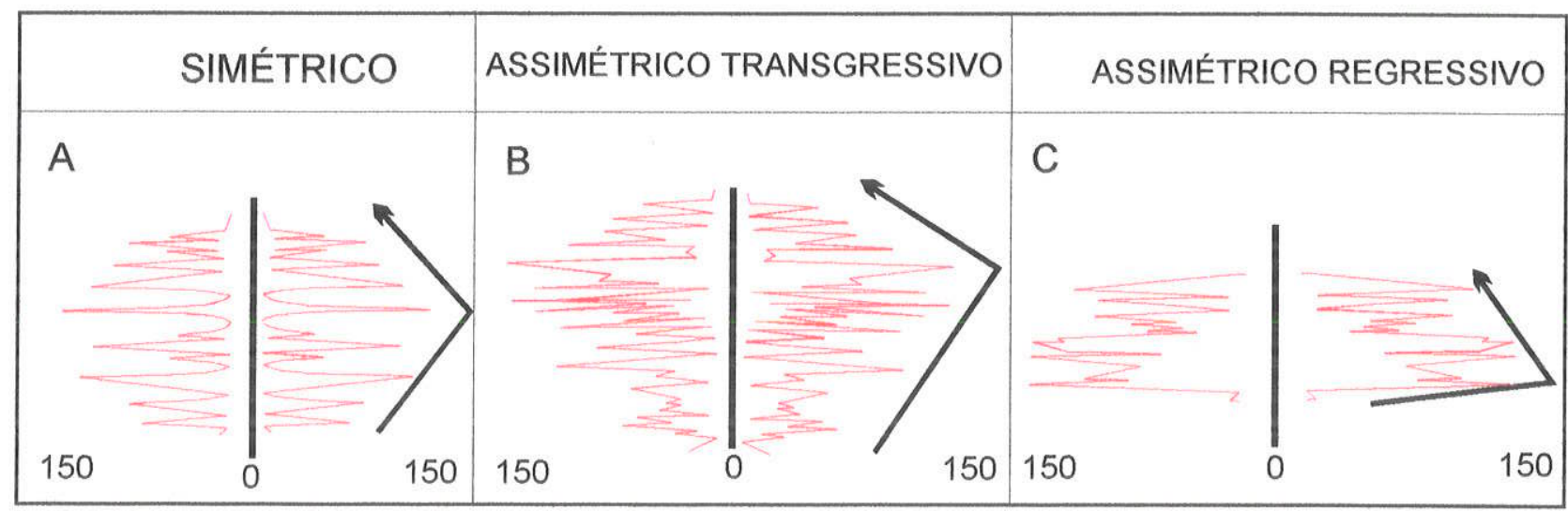

Fig. 6.7.1 - Padrões de empilhamento cíclico observado em imagem-espelho de perfis de raios gama. O ponto de inflexão da linha preta indica a posição da provável superfície de máxima inundação marinha. A escala é a mesma nos três exemplo (Segundo Becker, 1997). 


\section{CALCÁRIO MOCAMBO}

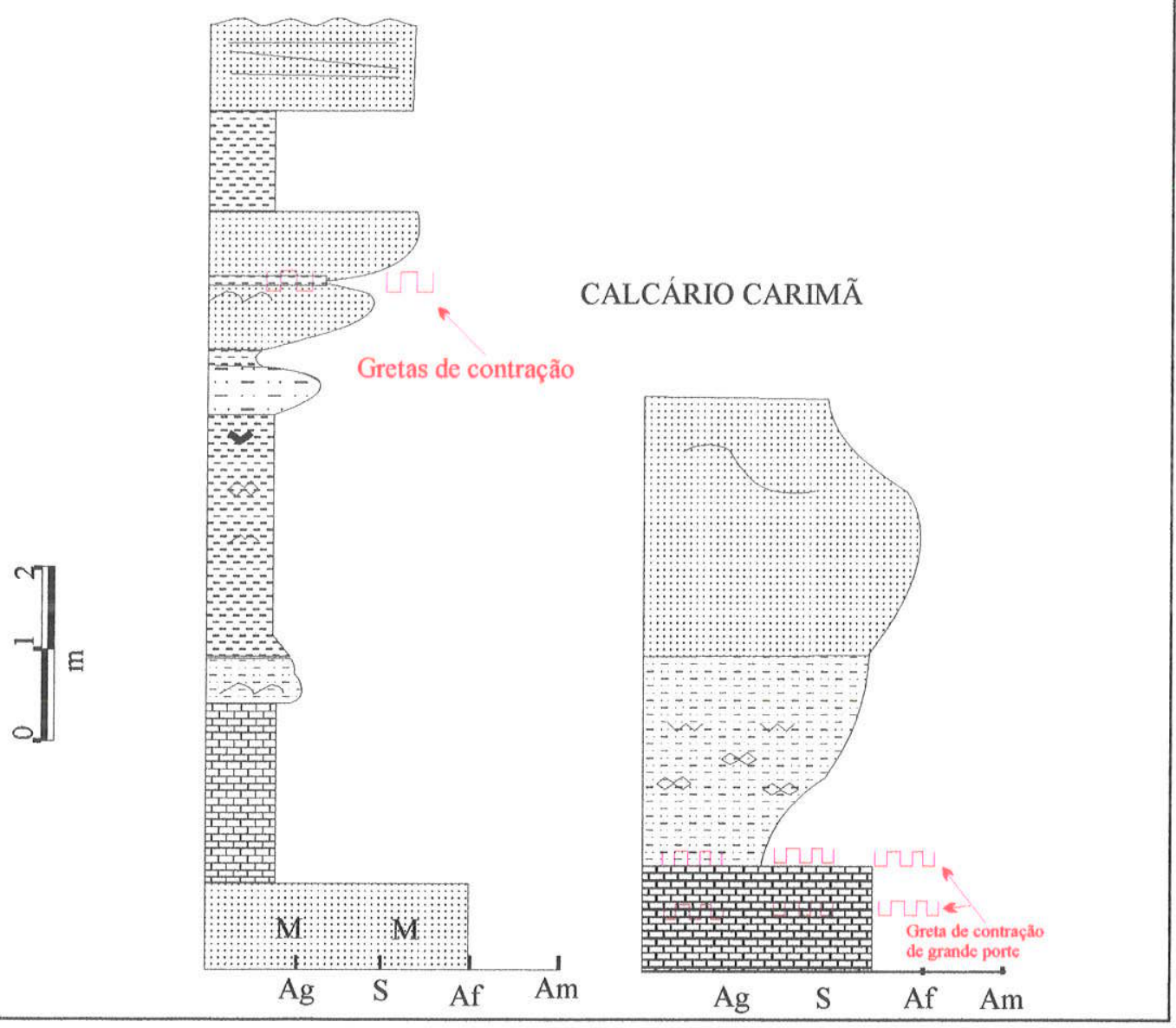

Fig. 7.7.1 - Calcário Mocambo e Carimã da Formação Piauí, borda nordeste da Bacia do Parnaíba. A presença de gretas de contração, na porção superior dos carbonatos ou em camadas associadas, como os exemplo, podem representar limites de seqüência de 3a ou 4a ordem. Estes calcários estão provavelmente posicionados na seqüência S4 ou S5, interpretadas para a borda leste da Bacia do Parnaíba (as figuras foram retiradas de Lima Filho, 1991a). 
Mesmo em afloramentos na borda oeste, o caráter de raseamento para o topo, com exposição subaérea é encontrado nos carbonatos como, por exemplo, na Mineração Jotademito (Fig. 8.7.1). Em afloramento, próximos a "boca" do poço 8 foram identificados depósitos de marés e pequenos deltas com frente deltaica retrabalhada por ondas de tempestade, sobreposta a dunas eólicas. Este limite de seqüência situa-se na transição da Formação Piauí para a Pedra de Fogo. 


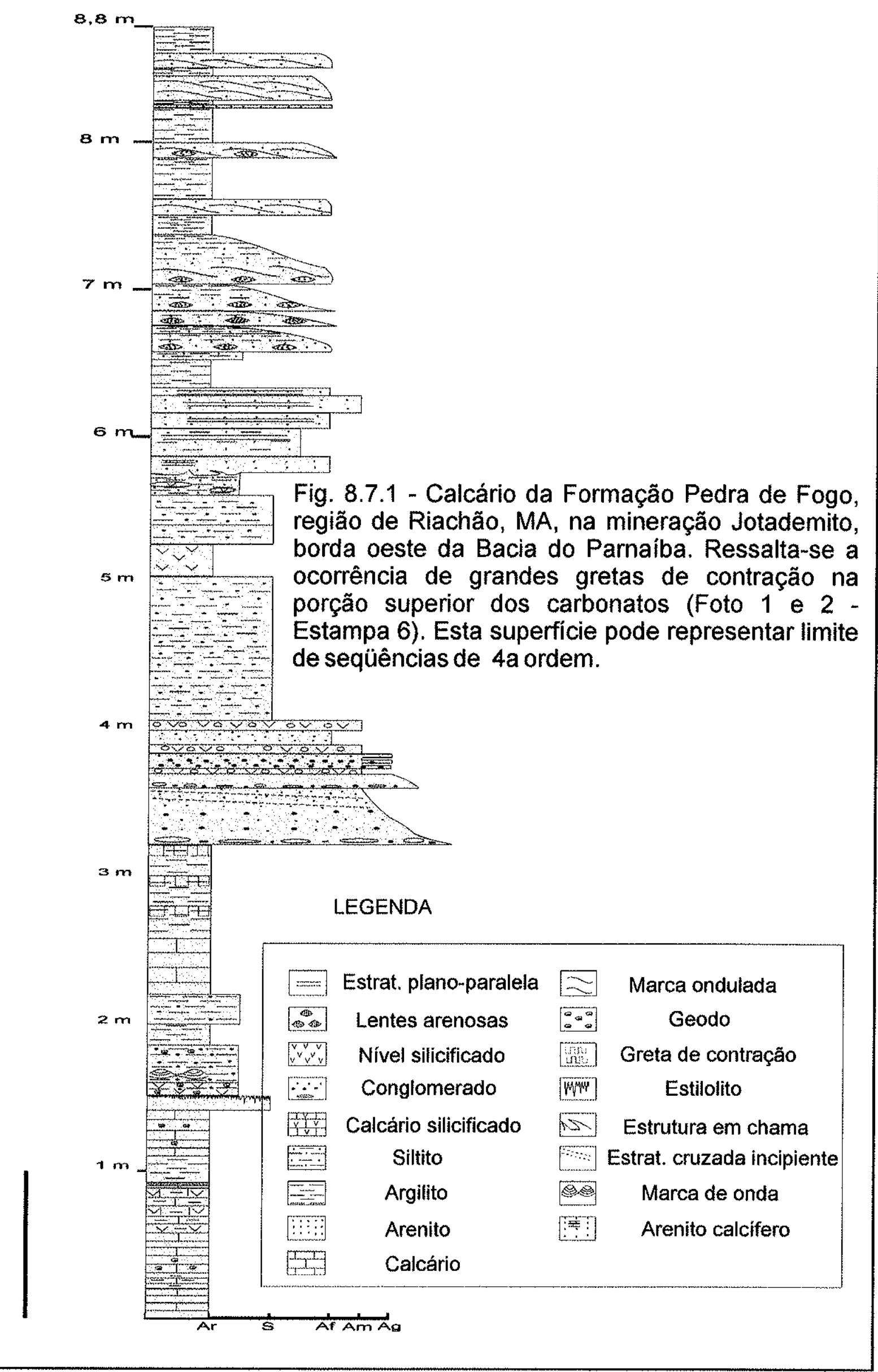




\section{8- ESTRATIGRAFIA DE SEQÜÊNCIAS EM BACIAS EVAPORITICAS/CARBONÁTICAS}

\section{1 . Introdução}

Exceto na borda leste, a Seqüência Permo-Pensilvaniana da Bacia do Parnaíba representa uma sucessão sedimentar depositada em bacia evaporítica/carbonática. A aplicação dos conceitos da Estratigrafia de Seqüências neste contexto difere, em linhas gerais, das aplicações em sucessões siliciclásticas. Serão apresentados aqui alguns modelos desenvolvidos para bacias de margem passiva, que servirão de subsídio teórico para elaboração do modelo da Sequência Permo-Pensilvaniana da Bacia do Parnaíba.

James \& Kendall (1992) enfatizam a necessidade de se usar diferentes abordagens para a perfeita compreensão dos mecanismos que controlam o empacotamento estratigráfico de rochas siliciclásticas e carbonáticas-evaporiticas, em função das diferenças genéticas entre estes tipos de depósito. Apesar do controle deposicional dos carbonatos e evaporitos está também submetido às mesmas variáveis que controlam a criação de espaço de acumulação dos sedimentos siliciclásticos como: a taxa de subsidência, a variação eustática e o influxo sedimentar, os carbonatos e evaporitos precisam ser analisados segundo algumas peculiaridades, como discutidos por Tucker e Wright (1990); Goldhammer et al. (1990), dentre outros. A principal diferença reside no fato dos sedimentos siliciclásticos serem originados primariamente pela desintegração e transporte de outras rochas pré-existentes que, posteriormente, são acumulados nos mais diversos sítios deposicionais. Desta forma, o seu fabric e o tipo textural está diretamente relacionado ao regime hidráulico, ou seja, a assinatura de algumas fácies está nas estruturas sedimentares e na variação granulométrica. Os carbonatos e evaporitos por sua vez, no geral, "nascem" como precipitados ou através da deposição de esqueletos do próprio sítio deposicional. Logo, os carbonatos possuem algumas características particulares como, por exemplo, a composição dos sedimentos (a microfácies que é fundamental na caracterização do ambiente deposicional); a variação no tamanho do grão (que não implica necessariamente em mudanças no regime hidráulico); grandes estruturas, como as plataformas, são produzidas inteiramente por sedimentos formados no local, eles são auto-gerados e auto-sustentados; e finalmente, 0 estilo de acumulação e respectivo tempo envolvido dependem sobretudo da natureza dos próprios sedimentos. Para os evaporitos, outros fatores especiais devem ser levados em 
consideração e que diferem dos siliciclásticos como, por exempio, o fato da mineralogia encontrada refletir as características químicas composicionais da água evaporada; os sedimentos não terem sofrido transporte (cresceram no próprio local ou abaixo da superfície sedimentar) e em sua maioria são depósitos de água rasa ou pelárgicos.

\section{2 - Sistemas Carbonáticos}

Apesar dos carbonatos ocorrerem em sítios deposicionais variados, a otimização da produção requer a conjunção de uma série de fatores conhecidos como Goldlock Window (Goldhammer et al. 1990). Destes fatores, incluem a profundidade da bacia, a temperatura e salinidade da água, disponibilidade de nutrientes, oxigenação e presença de siliciclásticos nos arredores, enfim, a abertura desta janela requer a coincidência entre fatores bióticos e abióticos de forma a permitir a alta produtividade carbonática. Uma janela deposicional similar também controla a acumulação dos evaporitos (James e Kendall, 1992). Grosso modo, deve existir um adequado influxo e refluxo d'água, altas taxas de evaporação e pouco influxo de siliciclásticos (Carvalho, 1987).

O primeiro modelo de aplicação da Estratigrafia de Seqüências em sucessões carbonáticas foi proposto por Sarg (1988), no qual as variações eustáticas de curta duração, superimpostas às mudanças tectônicas de longa duração, que afetam a morfologia deposicional e a distribuição das fácies, são considerados os principais fatores controladores das variações de produtividade carbonática. Seguindo o esquema de Estratigrafia de Seqüência do grupo da Exxon, Sarg (op. cit.), também subdividiu as seqüências carbonáticas em tipo 1 e tipo 2. O primeiro tipo é identificado por erosão, local ou regional, da frente do talude e exposição subaérea da plataforma, permitindo assim a entrada de água meteórica, ocasionando dissolução, precipitação de cimentos freáticos e dolomitização dos sedimentos. No segundo tipo de seqüência, a atuação dos processos diagenéticos se restringe às porções mais internas da plataforma. Para este autor, as plataformas carbonáticas desenvolvidas em nivel de mar alto são caracterizadas por espessa geometria agradacional a progradacional, apresentando dois tipos básicos, as plataformas keep up, caracterizadas por alta taxa de acumulação de sedimentos, capaz de acompanhar até as rápidas subidas do nível do mar, concentrando a maior produtividade na margem da plataforma; e as plataformas tipo catch up onde predominam baixas taxas de acumulação de sedimentos, com deposição de lamas carbonáticas 
submetidas ao processo de cimentação eodiagenética. Sarg (op. cit.) identifica ainda três tipos de depósitos carbonáticos no trato de sistema de mar baixo. O primeiro é formado por material autóctone, derivado de erosão do talude; o segundo tipo corresponde a depósitos de cunhas autóctones no talude superior, durante os estádios tardios de descida do nível do mar; enquanto o terceiro é representado pelas cunhas de margem de plataforma. Podem ocorrer evaporitos associados aos limites inferiores das seqüências tipo 1 e tipo 2. Este modelo foi bastante criticado por sua semelhança "forçada" com o modelo de Estratigrafia de Seqüências para rochas siliciclásticas e por ter sido concebido apenas para bacias com morfologia de plataforma com borda (rimmed shelves).

Outros modelos complementares foram, posteriormente, propostos como, por exemplo, Calvet et al., (1990), Tucker \& Wright (1990), Hunt \& Tucker (1991, apud Myers, 1998), James \& Kendal (1992) e Myers (1998), apenas para citar alguns exemplos.

James \& Kendall (1992) criticam o modelo de Sarg (1988) e apresentam um modelo alternativo. Nesse modelo, comparam os tratos de sistemas siliciclásticos e carbonático/evaporíticos equivalentes, em bacias com a morfologia de plataforma com borda, durante flutuações de nível do mar de $3^{\mathrm{a}}$ ordem com superimposição de $4^{\mathrm{a}}$ ordem. É mostrado também a ocorrência de evaporitos em TSMB, TST e TSMA.

Durante O TSMB a deposição de carbonatos ocorre de forma oposta a siliciclástica. Enquanto há acumulação de cunha e leque de mar baixo no limite inferior da seqüência siliciclástica, os carbonatos formam uma estreita plataforma e a bacia apresenta um comportamento "faminto" com deposição de evaporitos no seu centro (Fig. 1.8.2).

No TST (Fig. 2.8.2) a construção sedimentar siliciclástica mais efetiva ocorre próximo à costa, enquanto a bacia apresenta-se "faminta". Os carbonatos apresentam um grande crescimento, com deposição significativa na borda da plataforma (recifes e corais) e no talude. Os evaporitos depositam-se em lagunas formadas pela barreira dos recifes e corais. 


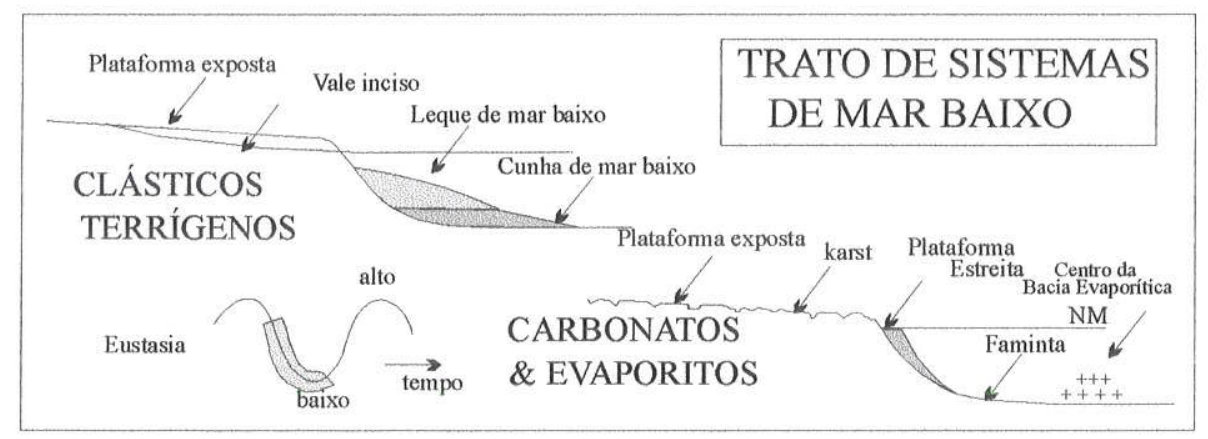

Fig. 1.8.2 - Modelo de bacia carbonática/evaporítica em TSMB com a comparação entre os depósitos siliciclásticos no mesmo trato de sistemas (James \& Kendall, 1992). Enquanto ocorre a deposição de espessa cunha siliciclástica, a bacia apresenta comportamento "faminto" durante a deposição de carbonatos/evaporitos no mesmo trato de sistemas.

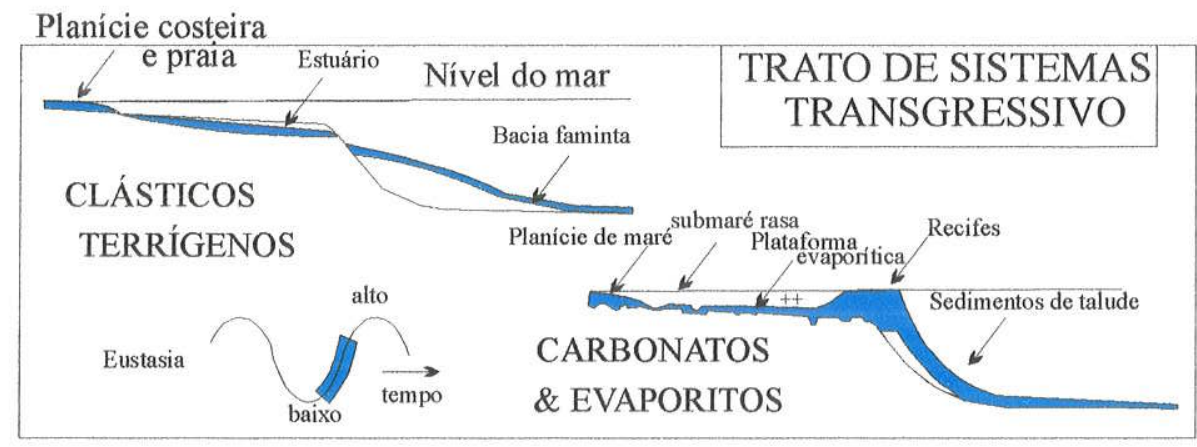

Fig. 2.8.2 - Modelo de bacia carbonática/evaporítica em TST e comparação com depósitos siliciclásticos de mesmo trato de sistemas ( James \& Kendall, 1992). As espessuras dos depósitos siliciclásticos e carbonatos apresentam-se com padrão inverso ao verificado no TSMB.

No TSMA (Fig. 3.8.2), em ambos os casos, a "produção" sedimentar excede a criação do espaço de acomodação e espessa cunha é criada. É mostrada também a associação de siliciclásticos/evaporitos e carbonatos/evaporitos na porção superior deste trato de sistema, em região proximal. 


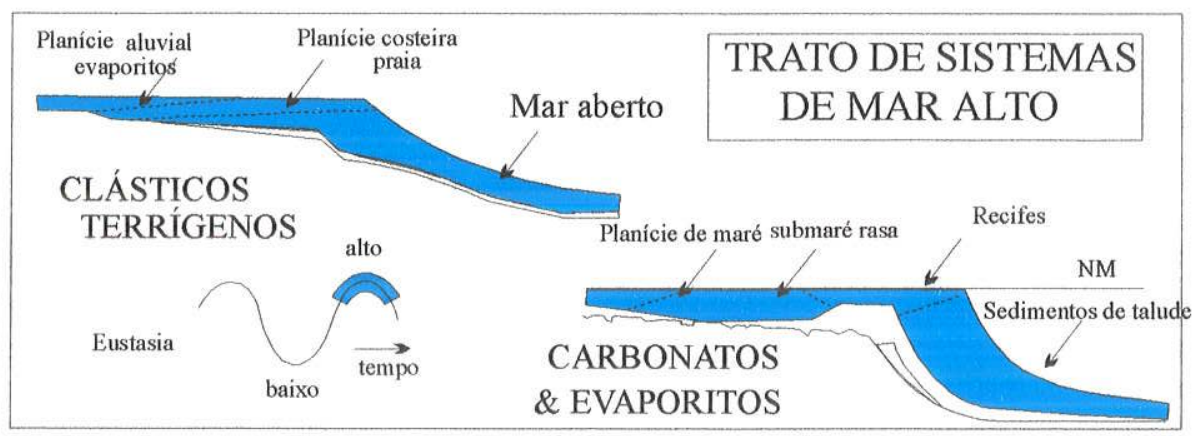

Fig. 3.8.2 - Modelo de bacia carbonática/evaporítica em trato de sistemas de mar alto e comparação com depósitos siliciclásticos de mesmo trato de sistema (James \& Kendall, 1992). Em ambas situações há deposição de espessura considerável.

Myers (1998) apresenta uma abordagem bastante elaborada do empacotamento estratigráfico de rochas carbonáticas segundo a ótica da Estratigrafia de Seqüências. Apresenta modelos para cada tipo de plataforma carbonática: modelo de sistemas de plataforma isolada, sistemas de rampas, sistemas de plataforma com borda e sistemas de margem escarpada. Este autor discute também a influência do clima, principalmente a diferença entre clima úmido e árido em tratos de sistema de mar baixo. A título de exemplificação é aqui apresentado o modelo esquemático de plataforma isolada, ressaltando-se a fase star up e catch up no TST, keep up no TSMA, plataforma exposta subaereamente no TSMB e plataforma afogada. As fases star, catch e keeep up foram

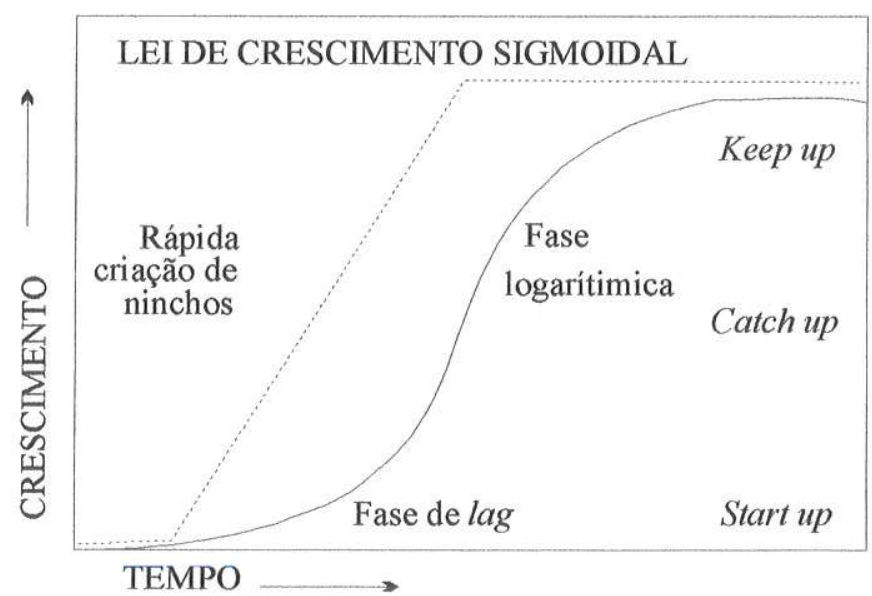

Fig. 4.8.2 - População versus tempo, indicando as fases star-up, catch-up e keep-up de Neuman \& Macintyre (1985, apud Myers, 1998). Observe a explosão biológica exponencial na fase catch up. 
obtidas da Curva de Crescimento Sigmoidal de Neumann \& Macintyre, (1985 apud Myers, 1998) e adaptadas à Estratigrafia de Seqüências. No início da produção carbonática, correspondente a fase star up ou fase de lag representada na porção inferior da curva da Lei de Crescimento Sigmoidal (Fig. 4.8.2), verifica-se um o pequeno crescimento carbonático. Apesar da taxa de subida eustática não ser muito alta, no início do TST, a pequena produção carbonática não consegue preencher o espaço de acomodação que está sendo criado, também chamado "espaço de vida". Na fase seguinte, denominada de catch up, apesar das altas taxas de subida do nível do mar, o crescimento carbonático apresenta uma grande explosão, como pode ser observado na porção mediana da curva, (Fig. 4.8.2) podendo até exceder a taxa de criação de espaço de acomodação. As duas fases estão representadas esquematicamente como correspondendo, respectivamente, a fase inicial e final do trato de sistemas transgressivo (Fig. 5.8.2).

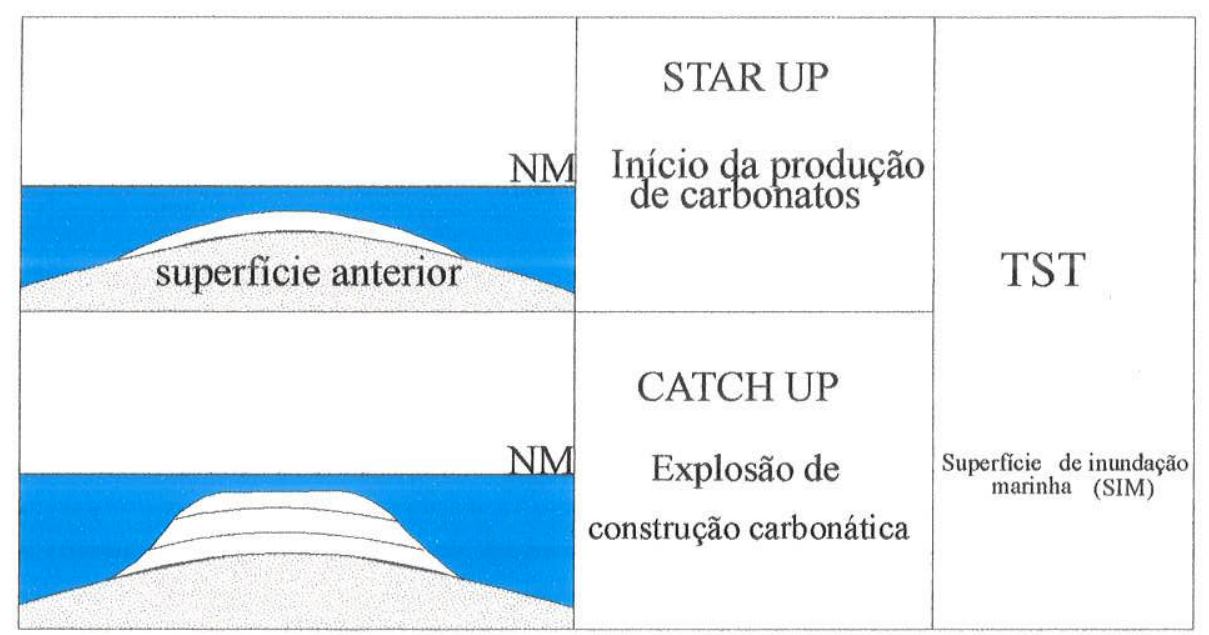

Fig. 5.8.2 - Modelo esquemático para uma plataforma isolada mostrando a relação entre as fases iniciais da curva de crescimento sigmoidal de carbonatos (star e catch up) e o trato de sistemas transgressivo (Myers, 1998). Mesmo com as elevadas taxas de subida eustática no início do TST os carbonatos conseguem acompanhar a elevação e permanecerem próximos à superfície.

$\mathrm{Na}$ fase keep up (Fig. 6.8.2) a capacidade de crescimento da população é limitada pela criação do espaço de acomodação, cada vez menor. As taxas de subida do nível do mar diminuem, podendo atingir valores negativos no final do trato de sistema de mar alto, respondendo pela limitação na criação de espaço de acomodação e, consequentemente, o crescimento vertical da plataforma. O limite superior da plataforma praticamente coincide com o nível do mar. 


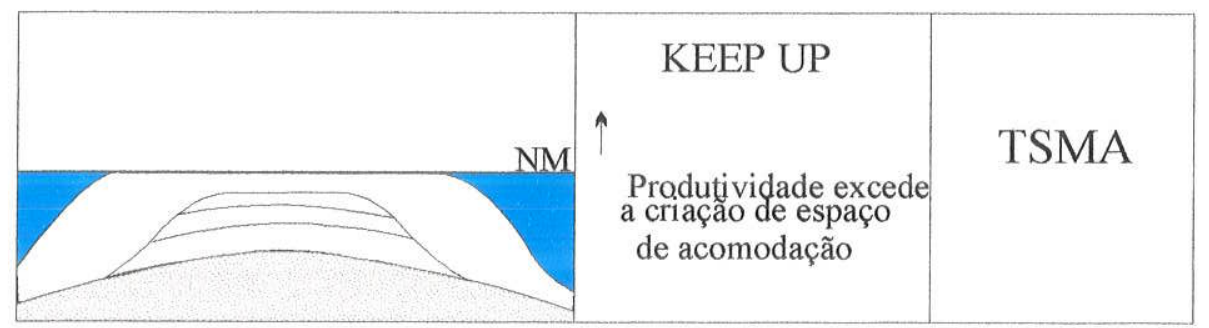

Fig. 6.8.2 - Modelo esquemático para uma plataforma isolada mostrando a relação entre a fase final da curva de crescimento sigmoidal de carbonatos e o trato de sistemas de mar alto (Myers, 1998).

No geral, a produção carbonática é diminuida no TSMB por que a área de águas rasas também será reduzida, marcando um forte contraste com os equivalentes siliciclásticos (Fig. 1.8.2). A produção ficará restrita às franjas de recifes ou pequenas plataformas carbonáticas. Ressalta-se que as rochas carbonáticas também respondem diferentemente das siliciclásticas aos processos erosivos. Durante a exposição subaérea, os carbonatos tendem a ser "erodidos" quimicamente, resultando na dissolução de grãos e cimentos e reprecipitação do material dissolvido. Em clima úmido se desenvolverá acentuado relevo cárstico (Fig. 7.8.2).

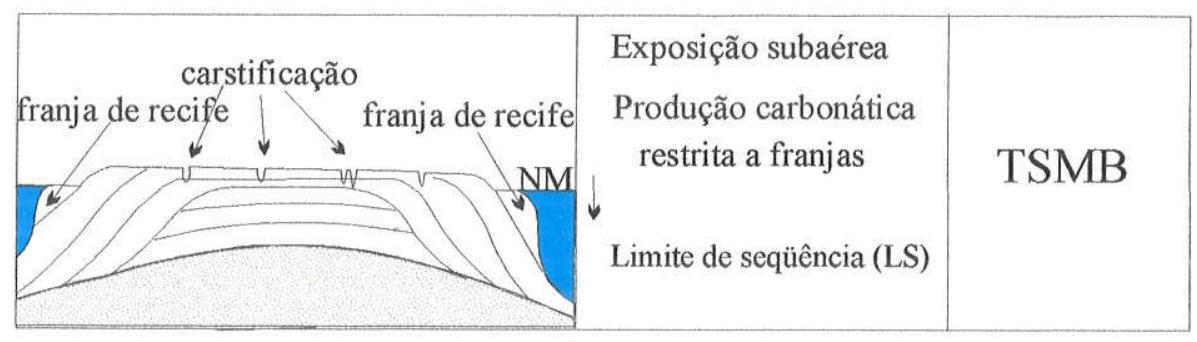

Fig. 7.8.2 - Modelo esquemático para plataforma isolada, mostrando as feições da plataforma carbonática encontradas no TSMB de mar baixo submetido a clima úmido. Neste trato, desenvolvem-se limite de seqüências situado na porção superior da plataforma (Myers , 1998).

A deterioração ambiental pode causar o fim da produção e do crescimento carbonático da plataforma, que posteriormente, "sem vida", será afogada e soterrada por material siliciclástico que progradará sobre ela.

Estes modelos recentemente apresentados na literatura acompanham o tendência dos estudos estratigráficos modernos, cujo desenvolvimento e aplicação se deu 
principalmente em bacias de margem passiva. Apesar da impossibilidade de aplicação integral desses conceitos em bacias tipo intracratônica, eles fornecem a viga mestre da nova abordagem que permitirá ao estratígrafo uma visão mais completa do empilhamento carbonático. A adequada aplicação de muitos destes novos conceitos na interpretação do empilhamento sedimentar carbonático possibilita reconstruções paleogeográficas, correlações de fácies e cronológicas mais eficientes, semelhante ao obtido em sucessões siliciclásticas. Apesar da presença de alguns fatores que diferenciam as bacias intracratônicas das bacias de margem passiva como, por exemplo, a ausência de uma plataforma com talude e pequena profundidade no interior da bacia já serem suficientes para exigir uma visão crítica dos conceitos apresentados, no entanto, não deve servir como empecilho a aplicação dos conceitos básicos da Estratigrafia de Seqüência a este tipo de bacia.

\section{3 - Sistemas Evaporíticos}

Numa representação simplificada os evaporitos podem ser classificados em continentais, de plataforma (ou de margem de bacia) e de bacia central (Kendall, 1992). O modelo de fácies para evaporitos continentais, segundo (Kendall, op cit.), é o de uma bacia fechada, com o lençol freático raso e centralizado no meio da bacia. Os evaporitos continentais que apresentam um volume substancial estão confinados à parte central dessas bacias e associados a playa lakes, panelas de sal (salt pans) e rodeados por planície de lamas salinas (saline mud flats). As porções inferiores da bacia normalmente não apresentam vegetação e possuem pouco relevo. Os depósitos de playa lake e planicie de sal se formam onde o lençol freático afiora, geralmente nas porções mais inferiores da bacia, cercados por planicie de lamas salina e planície seca, passando lateralmente a planície arenosa, contíguas e leques aluviais. A associação de evaporitos com depósitos de leques aluviais, de canais efêmeros, eólicos, redbed e carbonatos lacustre sugere fortemente a origem não marinha. Evaporitos precipitados exclusivamente de água subterrânea continental não são comumente reconhecidos no registro geológico, especialmente antes do Terciário. Muitos evaporitos movem-se para cima na mesma taxa da acresção sedimentar, por isso não são cumulativos. Assim, as evidências deste tipo de depósitos evaporíticos não ficam claramente registradas, contudo, sua presença pode ser 
deduzida por moldes de cristais e modificação das estruturas deposicionais (Kendall, 1992).

Os depósitos de margem de bacia (ou plataforma) podem apresentar variada extensão, atingindo até $1000 \mathrm{~km}$, e lâmina dágua bastante rasa (Fig.1.8.3). Ocorrem como sabkha costeira ou como salina costeira (salina marinha marginal). As sabkhas costeiras são produtos de processos deposicionais e diagenéticos, onde a diagênese precoce de sulfato de cálcio é o processo mais importante. A ação da água subterrânea torna a concentração de sal maior em direção ao interior da bacia. A concentração se dá por evaporação, pela ação capilar e pela dissolução de sais precocemente formados, particularmente por halita. As sabkhas que se ampliam como resultado de progradação costeira tem uma associação sedimentar característica, consistindo de sedimentos de submarés (laguna restrita) na base, sedimentos de intermarés, incluindo material algal, crostas cimentadas e sedimentos de supra-marés, com abundante gipsita (Kendall, 1992).

O modelo de bacia evaporítica central (Kendall, 1992) não apresenta análogo moderno. Os depósitos evaporíticos em bacias com pouco relevo são similares a evaporitos de plataforma, exceto por sua distribuição no centro da bacia. São compostos exclusivamente pelas fácies de água rasa ou planície de lama. Os espessos evaporitos de centro de bacia são unidades estratigráficas intercaladas com carbonatos marinhos ou marinhos restritos. Os carbonatos representam intervalos de perda de salinidade ou episódios em que a bacia foi inundada por águas marinhas normais (depósitos de TST ou TSMA). Três principais tipos de bacias evaporiticas podem ser distinguidas: modelo de bacia rasa de água rasa; modelo de bacia profunda de água rasa; modelo de bacia profunda de água profunda (Fig.1.8.3).

O modelo de bacias de água rasa foi desenvolvido para bacias intracratônica, que possuem como características: baixa taxa de subsidência e pouca profundidade. Exibem as fácies de planícies de lama, fácies subaquáticas rasas na parte superior do ciclo carbonático, mostrando sinais de restrição.

As bacias evaporíticas que estão constantemente alimentadas pela água do mar tendem a apresentar os depósitos mais significativos. Nesta bacias, os principais fatores 


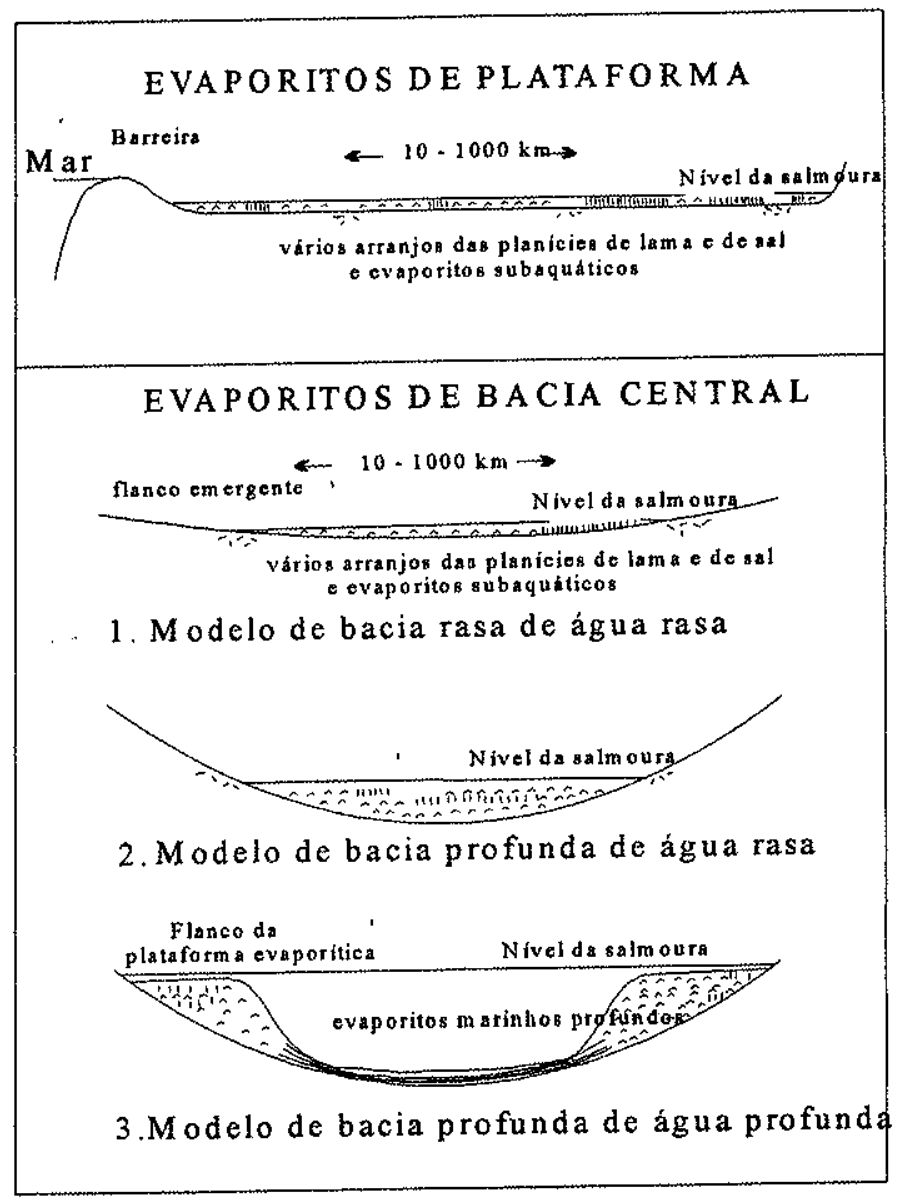

Fig. 1.8.3 - Representação esquemática das bacias evaporíticas tipo plataforma e central (Segundo Kendall, 1992).

que controlam a formação e preservação de depósitos evaporíticos são a hidrologia, concentração e composição dos sais (Kendall, 1992). A formação de evaporitos marinhos requer a existência de condições essenciais básicas (Fig.2.8.3) como demonstrado por - Carvalho (1987): 1) O influxo é responsável pela contínua älimentação dả bácia: Apesar de ser necessário um grande volume de água marinha para formação de depósitos evaporíticos consideráveis, $\bigcirc$ influxo não pode ser muito intenso para não causar diluição da salmoura. Logo, para que haja precipitação o influxo não deve ser maior que a taxa de evaporação, durante períodos prolongados. Kendall (1992) ressalta que um único aporte marinho na bacia deposicional, mesmo em bacias profundas, não é suficiente para 
produzir um depósito significativo. Portanto, é necessário que haja uma constante e controlada alimentação de água marinha para a bacia evaporítica. 2) A barreira é a controladora do influxo. Esta regulagem é feita através de barreiras que podem ter origem orgânica, associadas à construção de recifes e corais; geomorfológica, pela progradação de barras ou ithas barreiras; ou, ainda, barreiras tectônicas. Lucia (1972) afirma que há uma relação entre a área total da bacia evaporitica e a área de ligação com o mar, devendo esta última não ultrapassar $1 / 8$ da bacia para permitir a formação de gipsita e halita. 3) A evaporação é a principal responsável pela formação de evaporitos. Estas rochas são mais suceptivas ao clima do que qualquer outro tipo de rocha. A sua presença fornece uma evidência inequívoca de aridez, embora, não necessariamente de clima quente. São encontrados evaporitos, por exemplo, em playas lake na Antártida (Kendall, 1992), contudo, a maioria dos evaporitos antigos esteja relacionada a presença de climas quentes e áridos. É exigido que a taxa de evaporação seja maior que a somatória do influxo de água do mar, da precipitação pluviométrica e do aporte de água subterrânea. 4) O refluxo consiste no retorno da água do mar, por densidade, após intensa evaporação do bacia. Durante o estágio inicial de entrada da água do mar na bacia são verificadas variações laterais na concentração da salmoura. As salinidades mais baixas estão restritas às zonas proximais (entrada), aumentando gradativamente em direção as regiões distais, forçando o retorno (refluxo) das salmouras mais densas em direção ao mar aberto. Durante as fases de baixa concentração, o seja, quando o nivel relativo do mar está alto, possibilitando razoável refluxo de saimora densa, não há possibilidade de criação de alta salinidade, permitindo apenas a deposição de minerais menos solúveis (carbonatos e sulfatos). Inversamente, nas fases de nivel de mar relativamente mais baixo, o refluxo das salmouras densas é diminuido ou mesmo ausente, ocasionando um aumento acentuado da salinidade, com precipitação generalizada de halita e sais de potássio nas regiões distais e centrais da bacia. 


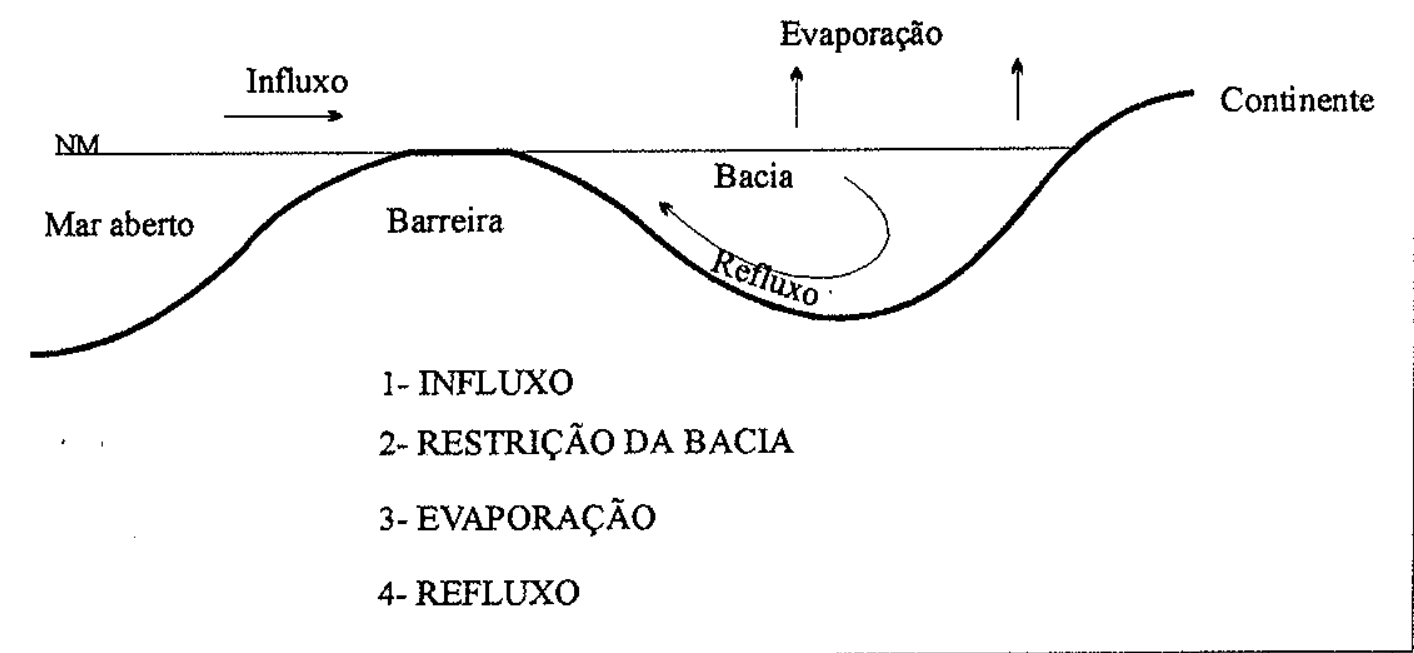

Fig. 2.8.3 - Princípios básicos para deposiçäo de evaporitos segundo Carvalho (1987). Este tipo de bacia é conhecido também como Modelo de Bacia Barrada (silled evaporites-basin) de Krumbein and Sloss (1963, depois de Briggs, 1957).

Existem muitos outros modelos de bacia evaporítica, e não é escopo do presente trabalho esgotar o tema. Entretanto, será apresentado mais um modelo de bacia evaporítica, denominado de bacia múltipla, aplicado à Bacia de Sergipe Alagoas por Carvalho et al., (1974). O modelo (Fig. 3.8.3) é representado por um conjunto de bacias interconectadas, obstadas por barreiras, o que ocasionam a retenção da massas d'água com pouca circulação, submetidas a intensa evaporação proporcionam a precipitação fracionada ao longo do trajeto da salmoura. Desta forma, nas bacias mais proximais seriam precipitados os carbonatos e, progressivamente, a medida que a salmoura vai se concentrando, nas porções mais afastadas da ligação com o mar, os sais mais solúveis seriam também precipitados.

Uma vez que a Bacia do Amazonas esteve conectada à Bacia do Parnaíba, durante parte do Paleozóico, inclusive no Permo-Pensilvaniano, poderia se supor um modelo deposicional tipo bacia múltipla para a deposição dos evaporitos contemporâneos das duas bacias. Entretanto, a presença de sais, progressivamente mais insolúveis depositados de oeste para leste na Bacia do Amazonas e ausência destes na Bacia do Parnaiba descaracteriza o modelo. Provavelmente, a ligação que existia entre as duas bacias estava restrita aos momentos de nível de mar mais alto. $A$ ausência de sais mais 
solúveis (halita e sais de potássio) que a anidrita na Bacia do Parnaíba, também sugere a existência de outra ligação da Bacia do Parnaíba com o mar (Lima Filho, 1991), possivelmente através da Bacia de Barreirinha.

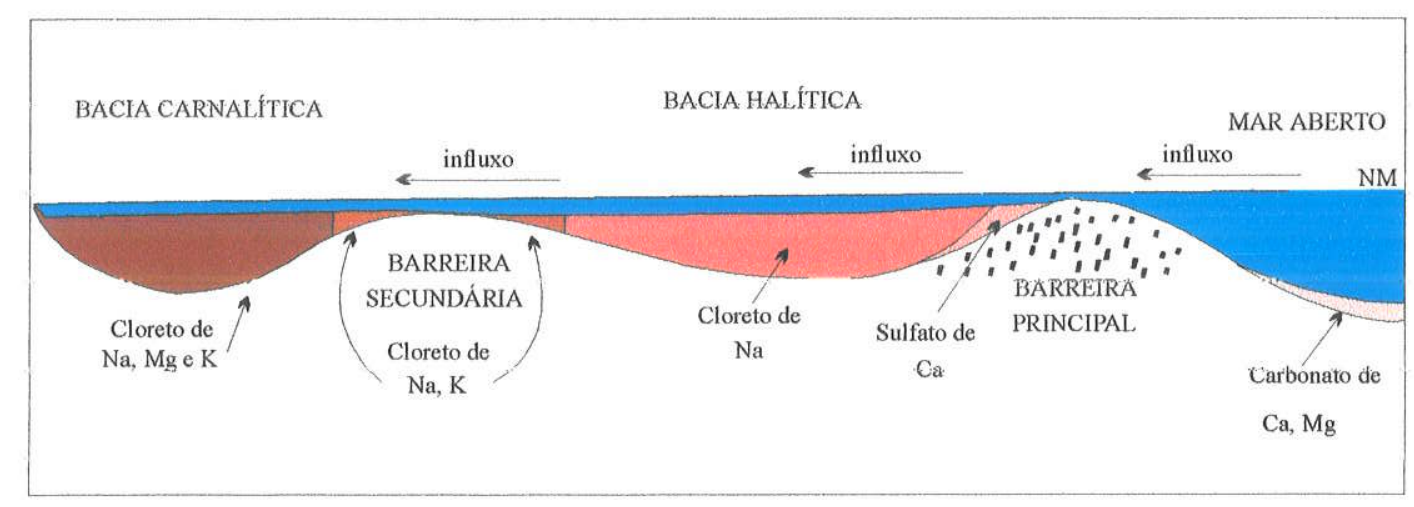

Fig. 3.8.3 - Seção esquemática de uma bacia múltipla. Os sais menos solúveis são depositados próximos à ligação com o mar aberto. Progressivamente, em direção ao interior da bacia são depositados os outros sais mais solúveis (Carvalho et al.,1974). 


\section{9- MODELO DEPOSICIONAL DA SEQÜÊNCIA PERMO-PENSILVANIANA NO INTERIOR DA BACIA}

O passo inicial para a montagem de um arcabouço cronoestratigráfico é a definição das superfícies físicas que limitam os conjuntos de ciclos e suas correlações laterais (Silva, 1996). O passo seguinte é a identificação do regime eustático. Nesta linha de investigação Silva (1996) e Backer (1997) analisam o modelo apresentado por Goldhammer et al. (1994) e o consideram aplicável as bacias do Amazonas e Solimões, respectivamente. Neste modelo (Fig.1.9) ○ TSMA é representado por folhelhos negros basais (superfície de máxima inundação marinha), e carbonatos num contexto de bacia faminta. O TSMB corresponde aos depósitos de gipsita, halita, sais de potássio e siliciclásticos oriundos da plataforma exposta, enquanto o TST é representado por depósitos de gipsita e folhelhos negros superiores. A arquitetura estratigráfica é montada segundo a ordem: TSMA, TSMB e TST.

Backer (1997) analisa a aplicação, na Bacia de Solimões, de dois modelos estratigráficos propostos por Tucker (1991). O modelo estratigráfico para "bacia carbonático-evaporítica sujeita a rebaixamento incompleto" que compreende sete estágios. Inicialmente, a bacia encontra-se conectada ao mar aberto, com formação de extensa sedimentação carbonática, sob a forma de plataformas distribuídas ao redor da bacia (TSMA). Quando o nível relativo do mar cai, suficiente para gerar restrição à circulação do mar aberto para a bacia, o nivel de água da bacia também tende a diminuir por evaporação. Torna-se hipersalina e ocorre precipitação de gipsita ao redor das plataformas, formando a cunha de mar baixo. A gipsita pode ser levada para águas mais profundas por tempestades, queda de talude, correntes de turbidez etc. Oscilações de alta freqüência do nivel do mar $\left(10^{5}\right.$ a $10^{4}$ anos) poderão alimentar periodicamente a bacia, formando parasseqüências de escala métrica. A posterior elevação do nível relativo do mar conectará a bacia ao mar aberto e resultará na deposição de carbonatos e anidritas retrogradacionais, representando o TST. A volta a salinidade normal favorece a formação de carbonatos nas plataformas marginais, segundo um padrão agradacional a progradacional. No fim do TSMA podem ser encontrados depósitos de finas camadas de evaporitos, regionalmente expressivas, de sabkha. Como definido no modelo, o limite de seqüência ocorre na superfície superior dos carbonatos de plataforma, como feições de exposição subaérea e/ou raseamento, podendo coincidir com a superfície transgressiva. 


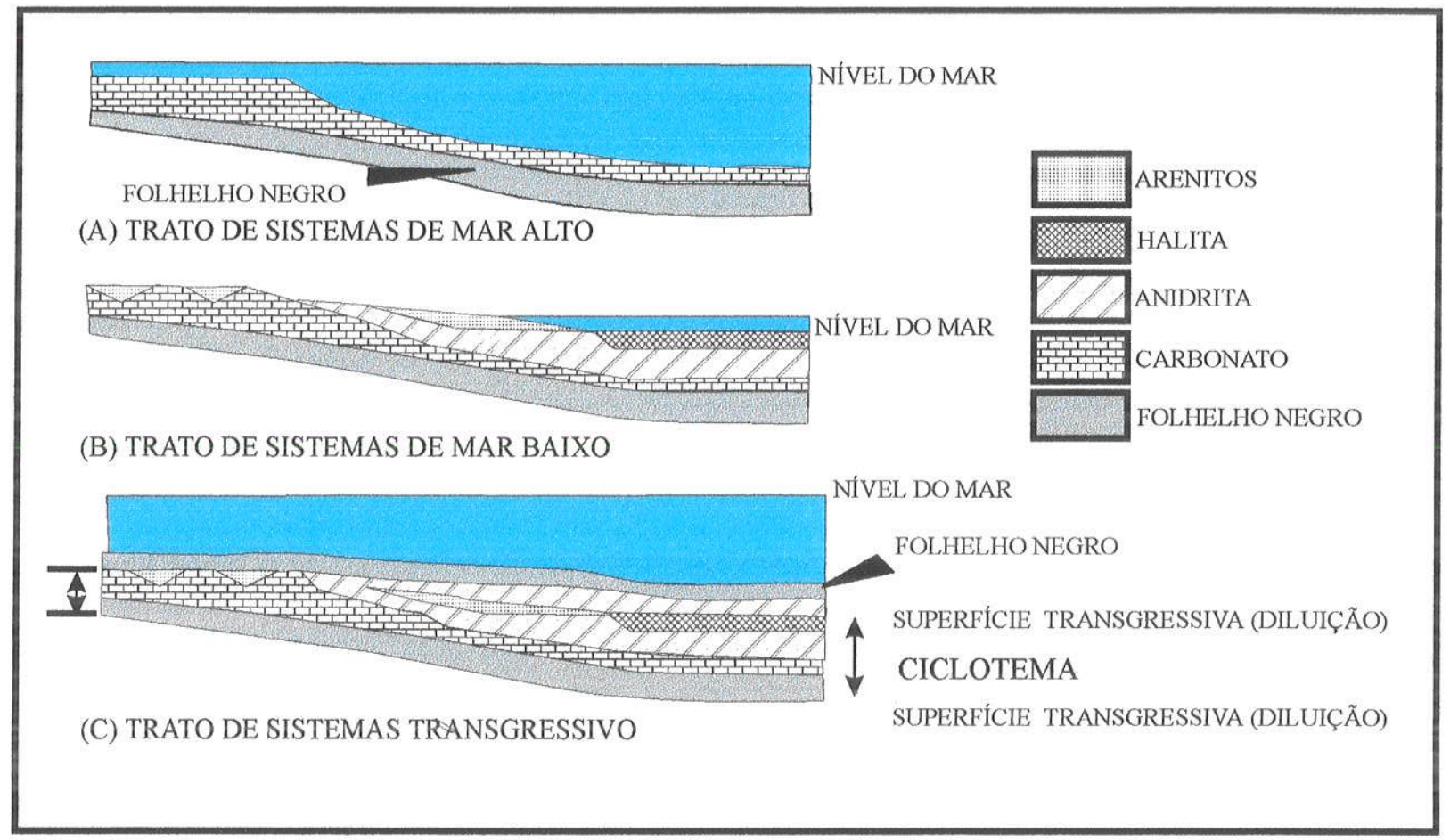

Fig. 1.9 - Modelo de bacia carbonática- evaporítica, com desenvolvimento dos tratos de sistemas e sua equivalência com ciclotema, utilizado por Silva (1997) para a bacia do Amazonas, a partir de Goldhammer et al. (1994). 
A concordância correlativa desta superfície, no interior da bacia, encontra-se na base dos evaporitos. O modelo dois, de "bacia carbonática-evaporítica sujeita a rebaixamento completo" difere do anterior, principalmente, pelo total isolamento da bacia em relação ao mar aberto, durante uma queda maior do nivel relativo do mar. Nesta situação, a intensa evaporação e ausência de refluxo propicia a precipitação de halita no fundo da bacia, em lagos salinos. Durante o TSMB podem ser encontradas cunhas marginais de gipsita e laminitos na porção central da bacia. Ocorre uma intensa dolomitização das plataformas carbonáticas circundantes. Durante o início do TST o comportamento da bacia pode continuar a ser evaporítico e na ausência de subsidência diferencial os carbonatos de TST e TSMA serão depositados em um mar extensivamente raso.

Becker (op. cit.) conclui que os três modelos se ajustam bem quando aplicados ao centro da bacia, onde a sedimentação é mais contínua. Entretanto, não são eficientes quando se busca a integração com toda bacia.

Em virtude do pequeno número de publicações enfocando os conceitos de Estratigrafia de Seqüências aplicados à sucessões evaporíticas, principalmente em bacias intracratônicas, e as características particulares da Bacia do Parnaíba, tornou-se necessário o desenvolvimento de um modelo próprio, onde foram adaptados os novos conceitos estratigráficos à realidade encontrada na Seqüência Permo-Pensilvaniana da Bacia do Parnaiba.

O modelo apresentado consiste de uma adaptação morfológica do modelo de bacia evaporítica barrada (Krumbein e Sloss, 1963, modificado de Briggs, 1957), cuja dimensão horizontal foi exagerada, aproximando-se assim das características morfológicas de uma bacia intracratônica: rasa e extensa. Em termos deposicionais as seqüências mostram a transformação de antigos mares rasos em lagos salinos (lago-maré no sentido de Ryan et al., 1973 apud Della Fávera, 1991) e posteriormente em extensos desertos, em resposta à formação da Pangéa (Della Fávera, 1991). Considerando-se as premissas que: 1) as seqüências permo-carboníferas do interior da Bacia do Parnaíba foram depositadas principalmente num contexto evaporítico (Lima Filho, 1991); 2) a deposição dos sais obedeceu a ordem normal de precipitação (ordem de solubilidade); 3) a composição do água do mar era aproximadamente a mesma de hoje; 4) desde o Pensilvaniano até o Permiano o mar penetrou ciclicamente no interior da Bacia do Parnaiba; 5) as características deposicionais mostram progressiva continentalização; 6) o clima mostravase progressivamente mais árido; 7) o sal mais solúvel precipitado durante o Permo- 
Pensilvaniano foi a gipsita; 8) os TSMB são pobremente desenvolvidos em bacias intracratônicas e muitas seqüências consistem de empilhamento de TST e TSMA (Lyndsay et al., 1993), é aqui proposto um modelo deposicional, a luz da Estratigrafia de Seqüências, para as rochas depositadas no Permo-Carbonífero na porção interior da Bacia do Parnaíba (Fig. 2.9).

O padrão mais comum de empilhamento corresponde a sucessão de seqüências de $3^{\mathrm{a}}$ ordem compostas de TST e TSMA.

O TSMA é representado por carbonatos (de plataforma) geralmente com padrão agradacional a progradacional, correspondentes, pelo menos em parte, à porção da curva que apresenta aumento da taxa de elevação eustática, e por parte da camada de anidrita, referente a posição da curva que apresenta diminuição na taxa de aumento eustático. Os carbonatos do TSMA quando depositados após o "fechamento" da bacia, são predominantemente químicos, refletindo as condições ambientais restritivas. Normalmente, mostram sinais de exposição subaérea ou de raseamento para o topo. A definição do limite superior do TSMA é de fundamental importância pois, na maioria das vezes, corresponde também a um limite de seqüências. No modelo proposto também é considerado que o limite superior do TSMA (e limite de seqüência) corresponda a superfície superior dos carbonatos de plataforma, com feições de exposição subaérea e/ou raseamento, como identificado nos carbonatos das regiões de José de Freitas, PI e de Riachão, MA (Fig. 7.7.1 e 8.7.1). Entretanto, difere quanto a equivalência da superfície correlativa no interior da bacia. Para Goldhammer et al. (1994) e Tucker (1991) esta superfície esta situada na base dos evaporitos. Para a Seqüência Permo-Pensilvaniana da Bacia do Parnaíba considera-se que a superfície esteja posicionada abaixo do topo da camada de maior salinidade, ou seja, a superfície limitante do TSMA encontra-se em algum lugar abaixo do topo de camadas de anidritas.

Existem duas questões relevantes a serem consideradas: por que a superfície limite encontra-se na camada de maior salinidade? Por que o limite de seqüência encontra-se abaixo e não no topo da camada?

No momento que é atingida a saturação de $\mathrm{CaSO}_{4}$ na salmoura, para o caso da Bacia do Parnaíba, (ou outro sal mais solúvel em outras bacias) a bacia apresenta máxima retração. Como o sal mais solúvel precipitado é a anidrita, há perda de aproximadamente $80 \%$ do total de água, por evaporação, para bacias que apresentem 


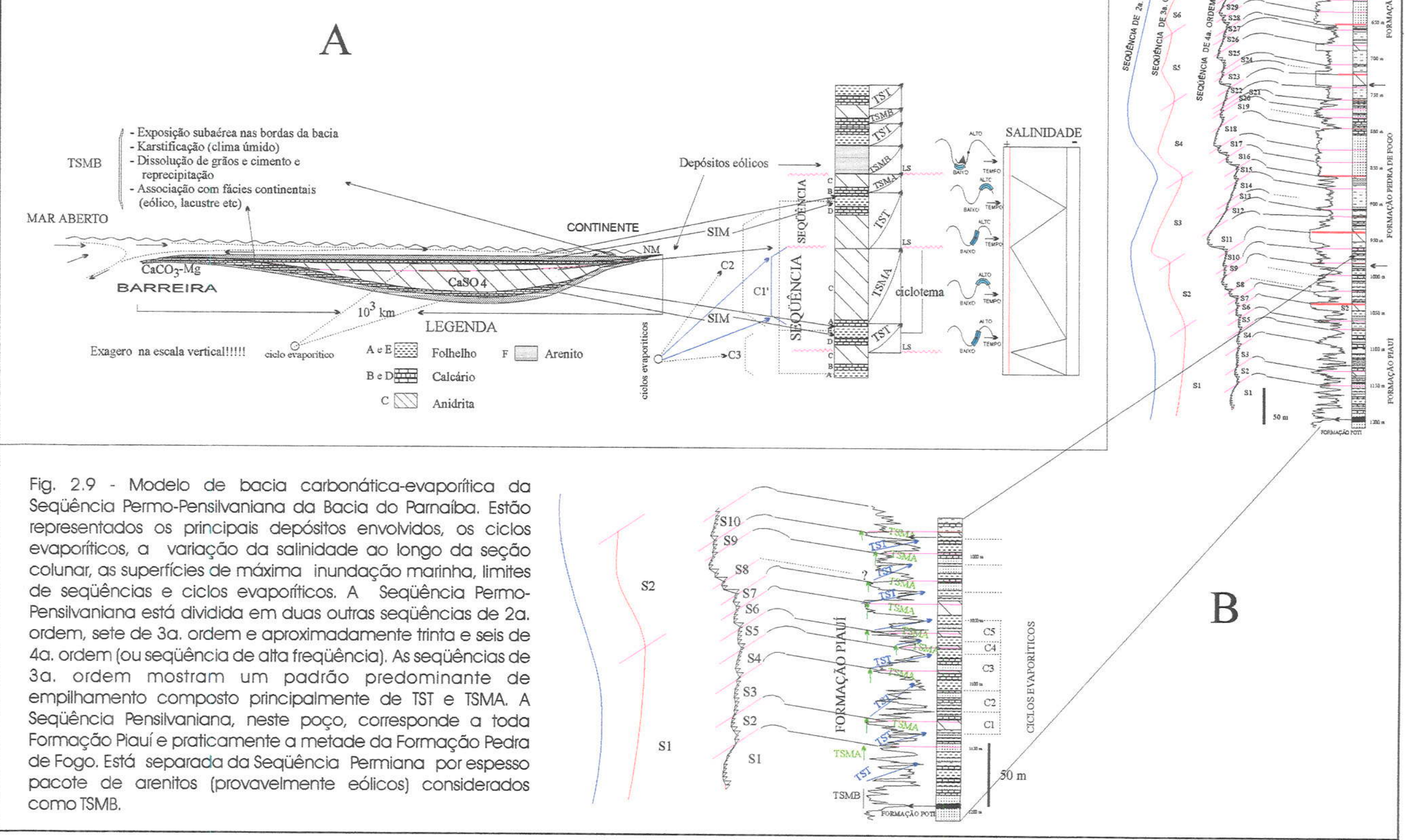


salmouras com altíssima concentração, precipitando de sais de potássio, a perda de água por evaporação chega a $95 \%$ do volume total (Sonnenfeld, 1992). A redução do volume da bacia implica em significativa exposição subaérea de suas bordas, desenvolvendo assim superfícies limite de seqüências. Uma vez que esta superfície limite será posicionada em algum lugar na camada evaporítica de maior solubilidade, há a tendência natural de posicioná-la no topo, assumindo-se implicitamente que em direção ao topo da camada de sal, mais árido é o clima representado e maior a restrição sofrida pela bacia. $\mathrm{A}$ curva de concentração/diluição da salmoura marinha (Sonnenfeld, 1992) mostra que, mesmo dentro da faixa de precipitação de um determinado sal, estas duas fases podem ocorrer representando progressiva concentração, na porção inferior da camada de evaporito, e diminuição progressiva da salinidade, na porção superior da camada (Fig. 3.9). A variação de salinidade dentro de uma mesma camada de evaporito pode ser observável, como mostram Florêncio \& Ribeiro Fitho (no prelo), a partir da análise do teor de bromo em camadas de halita, da Bacia de Sergipe Alagoas (Fig. 4.9). Fica patente uma fase de salinidade progressiva, até aproximadamente a porção mediana da camada e uma fase seguinte de salinidade recessiva. O resultado das análise químicas, do teor de bromo, realizadas por Florêncio \& Ribeiro Filho (op. cit.) mostra que o momento de maior salinidade, correspondente a retração máxima da bacia, não deve, necessariamente, coincidir com o topo do depósito evaporítico.

A porção situada acima do ponto de máxima salinidade pode corresponder a uma tendência da bacia apresentar diminuição progressiva de salinidade, até atingir a salinidade normal de mar aberto, e posterior deposição dos folhelhos negros superiores. Ou seja, em relação ao ponto de maior concentração salina, a porção acima mostra o início da fase expansão da bacia, logo, o nível relativo do mar começa a elevar-se ainda durante a precipitação da camada de sal mais solúvel. A tendência de subida do nível relativo do mar pode ser considerada como o início do TST (3.9), compreendendo na seção estudada a porção superior da camada de anidrita, os carbonatos (de mar aberto, tipo D), folhelhos transgressivos e os carbonatos (evaporíticos, tipo B) do início do ciclo evaporítico seguinte (Fig. 2.9.A). Na maioria das vezes o TST apresenta-se bem desenvolvido, facilmente identificado em perfis de raios gama pelo seu caráter transgressivo ressaltado pela argilosidade (Fig. 2.9.B). 


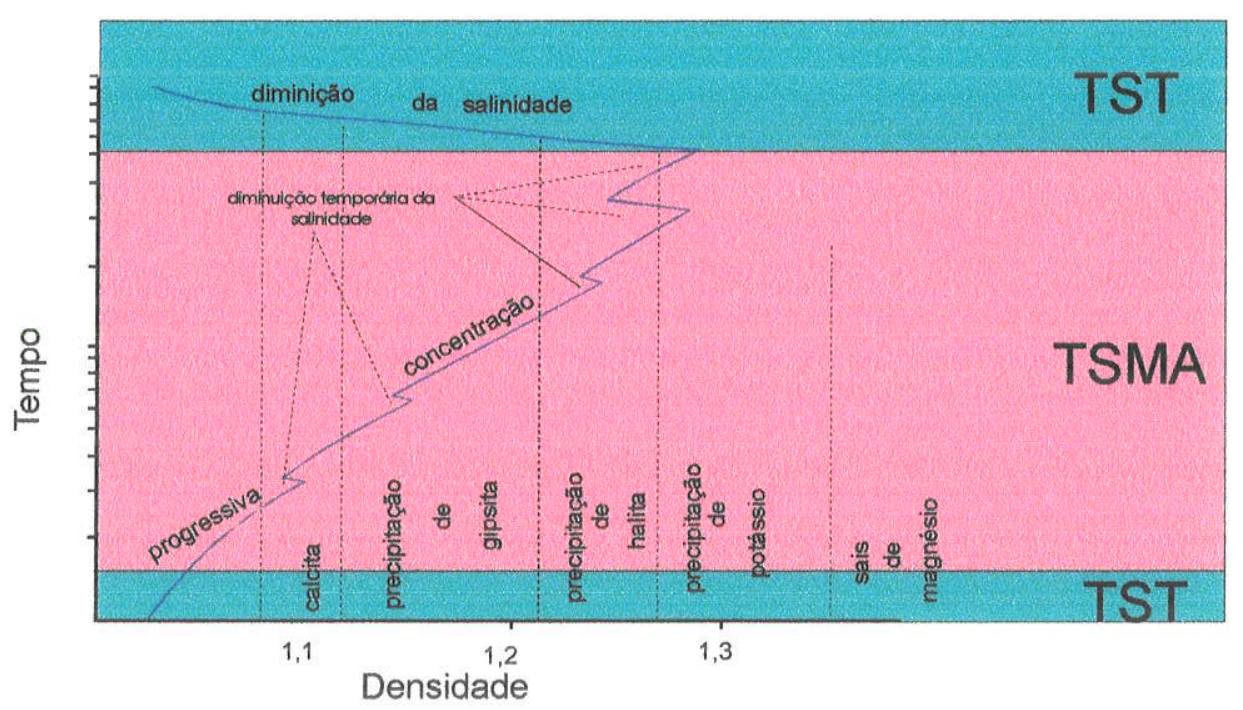

Fig. 3.9 - Curva de concentração e diluição da salmoura marinha (Modificado de Sonnenfeld, 1992). Da mesma forma que um ciclo evaporítico completo mostra um padrão de salinidade crescente até um ponto máximo, passando para valores de menor salinidade, na faixa de precipitação dos minerais evaporíticos, também podem ser evidenciados padrões de aumento e diminuição de salinidade. Quando estes padrãos de diminuição de salinidade persistem, com precipitação de sais menos solúveis e follhelhos negros, representam períodos de expansão da bacia. É proposta uma relação entre os tratos de sistemas e a ordem de precipitação dos minerais evaporíticos. 


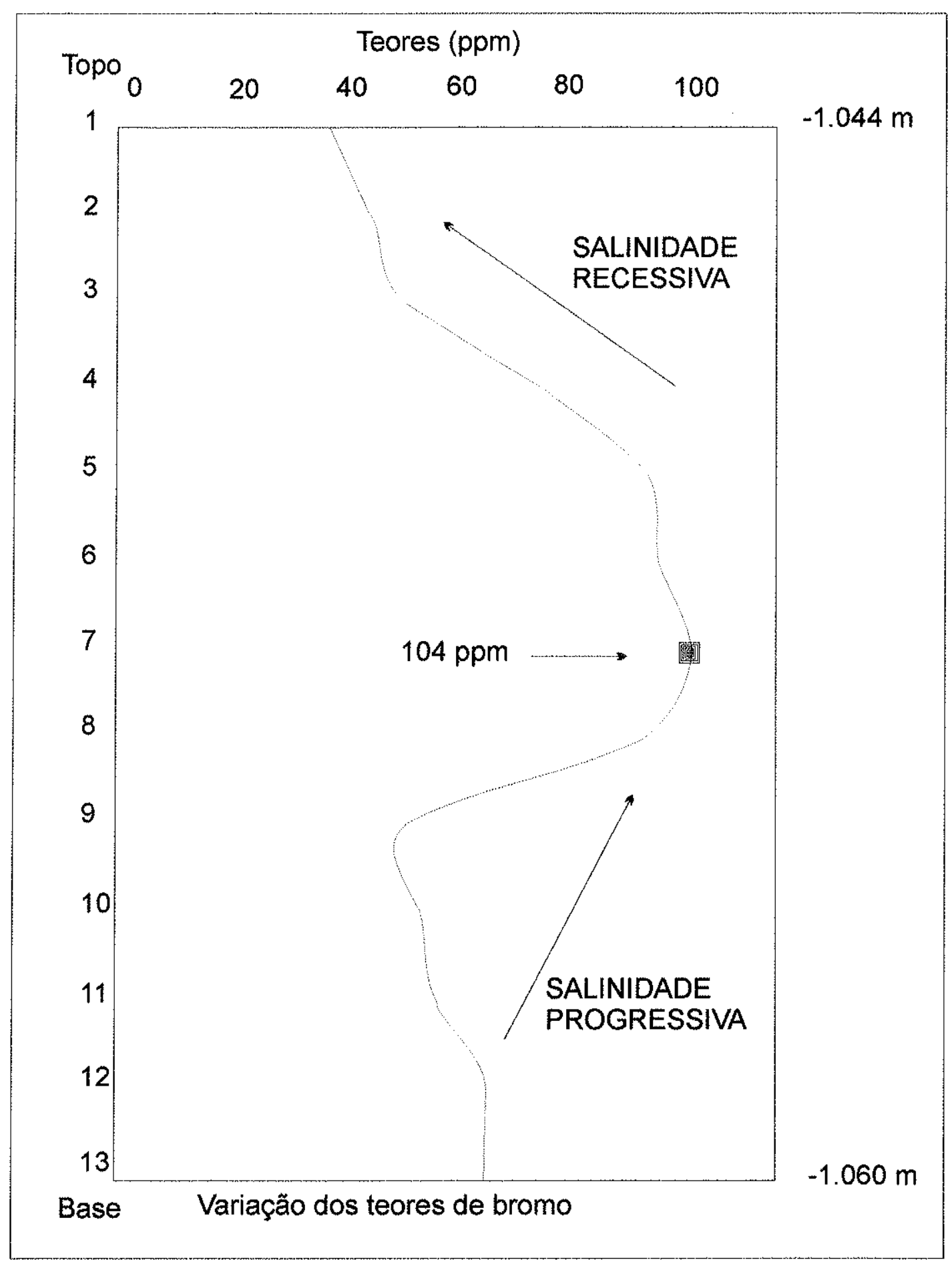

Fig.4.9 - Amostras de halita, coletadas em testemunhos contínuos na Bacia Sergipe Alagoas, mostram um padrão de aumento de salinidade na porção inferior (aumento do teor de bromo) e diminuição na porção superior (diminuição do teor de bromo). O comportamento do bromo mostra que o pico de salinidade não corresponde, necessariamente, ao topo do corpo evaporítico, mesmo que esta camada de sal esteja em contato outra camada salina de menor solubilidade. Apesar deste exemplo apresentar uma feição simétrica na curva de variação do bromo, acredita-se que ocorram geometrias diversas, predominando aquelas com o ponto de inflexão deslocado em direção ao topo da camada de maior salinidade. Figura retirada de Florencio \& Ribeiro Filho (no prelo). 


\subsection{Introdução}

A cicloestratigrafia como concebida por Perlmutter \& Matthews (1989) serviu de base para que o grupo da Exxon revisse os conceitos que explicam os mecanismos de criação de espaço de acomodação. O clima passou a ser considerado um fator de importância na definição das assinaturas estratigráficas. No modelo de Perlmutter \& Matthews (op. cit.) é levado em consideração, além da evolução tectônica da bacia, os eventos climáticos de curta e longa duração, induzidos por parâmetros orbitais de Milankovitch. Para Vail et al. (1991) a tectônica e eustasia seriam conjuntamente os responsáveis pelas mudanças relativas do nível do mar que controlam a criação de espaço de acomodação, enquanto a tectônica e o clima controlam a quantidade e o tipo do sedimento depositado.

Devido a necessidade premente de datação dos fenômenos geológicos foi proposta uma classificação de eventos cíclicos com base na duração. A classificação permite a hierarquização desses eventos em uma determinada área para comparação com áreas distintas, desde que apresentem magnitude compatíveis. Os ciclos foram divididos em dois grupos: os de periodicidade irregular $\left(1^{\mathrm{a}}, 2^{\mathrm{a}}\right.$ e $3^{\mathrm{a}}$ ordem) e os de periodicidade regular ( $4^{\mathrm{a}}$ e $5^{\mathrm{a}}$ ordens). Os ciclos de $1^{\mathrm{a}}$ ordem tem sua origem atribuída a variações volumétricas dos oceanos, geradas pela junção e separação de supercontinentes (Bond et al., 1984) e duração variando entre 200 e $400 \mathrm{Ma}$. Com período variando de 10 a $100 \mathrm{Ma}$, os ciclos de $2^{a}$ ordem, são gerados em função de variações do volume das cadeias meso-oceânicas, controladas pela taxa de expansão oceânica. O exemplo clássico são as seqüências de Sloss (1963), equivalentes aos sintemas de Chang (1975). Os ciclos de $3^{a}$ ordem com duração variando entre 1 e $10 \mathrm{Ma}$, tem sua origem disputada por eustasistas e os tectonistas.

Nenhum período geológico apresentou um registro com tanta ciclicidade envolvida quanto o Carbonifero. Wanless \& Weller (1932) cunharam o termo ciclotema para designar uma série de camadas depositadas durante um ciclo sedimentar singular, do tipo que predomina no Pensilvaniano. Hoje, entretanto, a palavra tem sido usada de uma forma genérica para se referir a rochas que apresentem diversos controles alocíclicos. 
Diversidades observadas nos ciclotemas de diferentes regiões do médio continente americano levaram a criação de três tipos de ciclotemas (Fig. 1.10.1): tipo lllinois, Kansas e Apalaches (Weller, 1930; Wanless \& Weller, 1932; Moore, 1936; Heckel, 1977). Moore (1950) identificou ciclos de maior ordem nos ciclotemas, envolvendo 3 ou 4 ciclos menores e os denominou de megaciclotema. Coube a Ramsbottom (1979) propor três classes hierárquicas para os ciclos eustáticos: ciclotema, mesotema e sintema. Para Wanless \& Shepard (1936) os ciclotemas derivam-se de transgressões e regressões geradas por flutuações glácio-eustáticas. Heckel (1985) identificou dois períodos de excentricidade (413 e 100 mil anos), um período de obliqüidade (41 mil anos) e dois de precessão (19 e 23 mil anos). Goldhammer et. Al. (1994) admitem que tanto o clima quanto a tectônica tem um papel importante na formação e desenvolvimento dos ciclotemas.

Silva (1996) reconhece a similaridade dos ciclos da porção média/superior da Formação Itaituba e da Formação Nova Olinda da Bacia do Amazonas, com ciclotemas do tipo Kansas. Identifica para a seção estudada três sintemas denominados de Sintema I (de idade Morrovano Superior com 2,4 Ma), Sintema II (de idade Atokano, com 4,2 Ma) e Sintema III (de idade Desmoniano com 4,1 Ma). A origem destes ciclos foi proposta por Silva (op. cit.) a eventos tectônicos globais.

Ao contrário dos ciclos identificados no continente norte-americano, depositados sob influência de clima úmido, os ciclos das Bacias do Solimões, Amazonas e Parnaíba apresentam registros de aridez climática, mostrando variações cíclicas de alta e baixa salinidade. São reconhecidos três principais tipos de ciclos evaporíticos, classificados segundo os seus limites: ciclos definidos a partir de camadas com menor salinidade na base, limitados acima por camadas de alta salinidade. Estes ciclos tem sido denominados de ciclos de raseamento para o topo, também identificados como ciclos de aumento de salinidade (Logman et al., 1983), particularmente quando as evidências de raseamento são duvidosas. São denominados também de ciclo tipo Zechstein (Fig. 2.10.1A). 0 segundo tipo, denominado de ciclo Paradox, é marcado por camadas de mais baixa salinidade na base e no topo, normalmente representados por camadas de carbonatos ou folhelhos. Estes folhelhos, quando presentes, permitem boas correlações em escala de bacia e correspondem às superfícies de máxima inundação. Este ciclo foi também chamado de ciclo químico ou litológico (Fig. 2.10.1B) por Peterson \& Hite (1969). O 


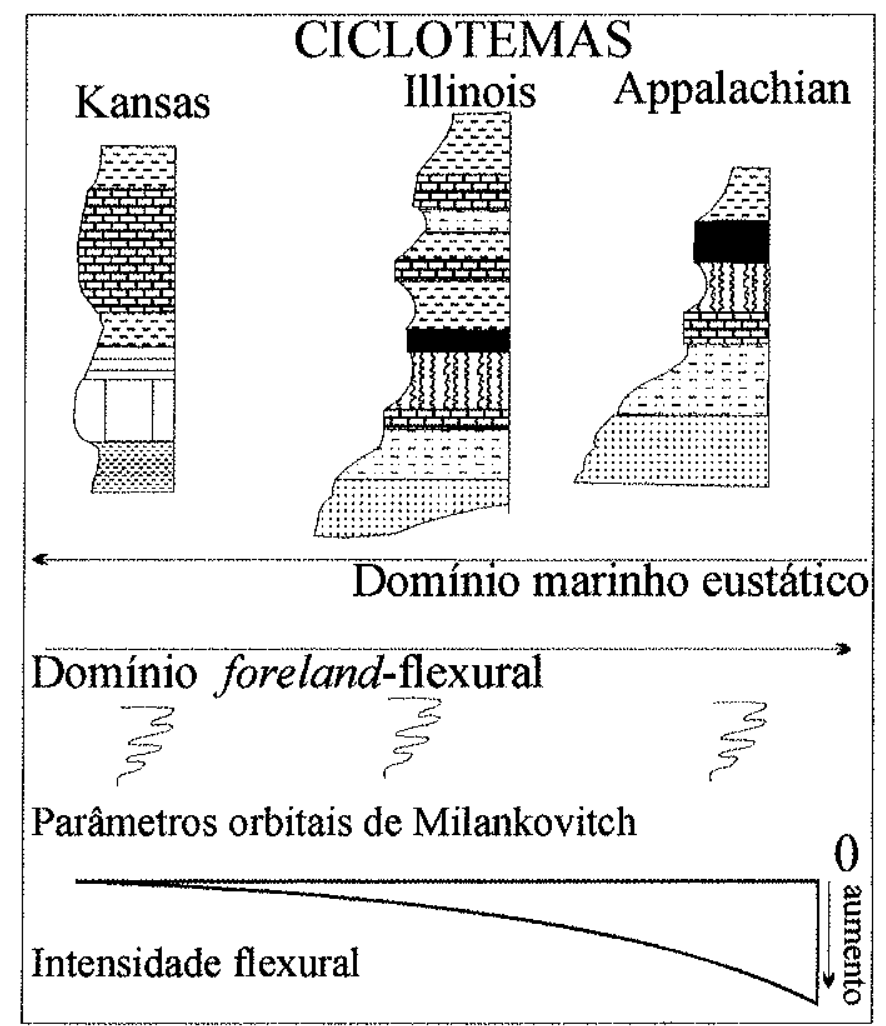

Fig. 1.10.1 - Os três principais tipos de ciclotemas dos EUA, mostrando a diferença na litologia, intensidade flexural da crosta e influência dos parâmetros de Milankovitch (Klein \&Wilard, 1989). 


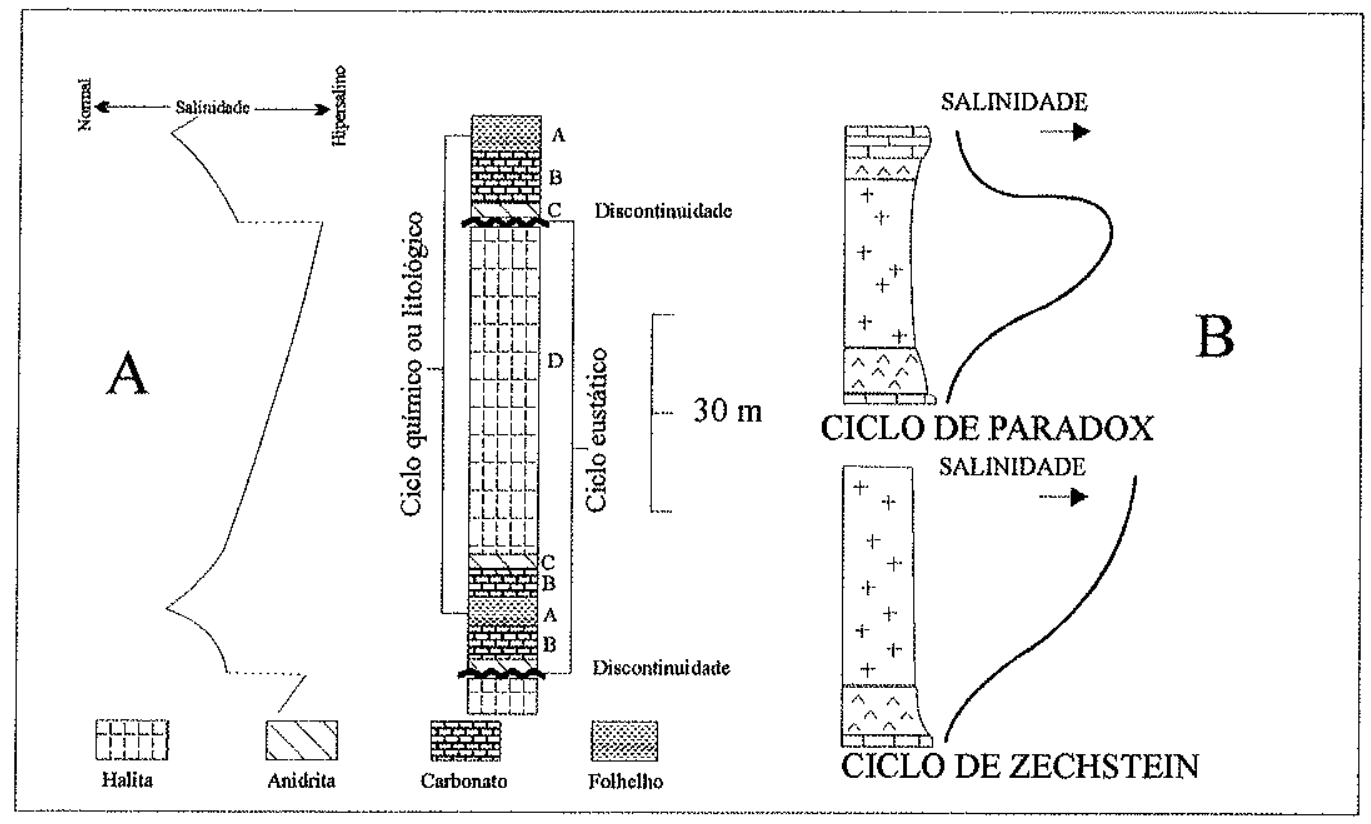

Fig.2.10.1 - Possibilidades de classificação dos ciclos evaporíticos segundo o seus limites. Na figura A, representação dos ciclos da Formação Paradox mostrando duas interpretações para limite de ciclo segundo Peterson \& Hite (1969). Na figura $B$, ciclos tipo Zechstein e Paradox (segundo Longman et al. 1983). 
último, denominado por Peterson \& Hite (op. cit.) de ciclo eustático é limitado por discordâncias e corresponde a uma seqüência de alta freqüência (Fig. 2.10.1B).

Becker (1997) observando a relação entre os ciclotemas e as seqüências evaporíticas, como o padrão assimétrico-regressivo, contemporaneidade e a origem comum nas variações glácio-eustáticas, e com base no modelo climático de Cecil (1990 apud Becker, 1997) mostra a equivalência entre os ciclotemas tipo kansas (Heckel, 1985) e às seqüências evaporíticas. Para Becker (op.cit.) o ponto-chave para estabelecer um padrão de comparação entre estas unidades é relacionar as litofácies a determinados trecho da curva eustática, uma vez que as duas unidades são o produto de condições climáticas extremas, onde os evaporitos correspondem a um clima quente e seco e os ciclotemas a clima temperado e úmido. Utilizando esta premissa e com base em estudos anteriores (p.e. Heckel, 1985; Goldhammer et al., 1994) que mostram a relação entre as associações faciológicas e a glácio-eustasia. Becker (op. cit.) apresenta a seguinte relação: para O TSMB a halita corresponde a paleosolos, os depósitos de sabkha aos carvões; para o TST as anidritas correspondem a arenitos fluviais $e$ os mudstones/wackestones correspondem a carvões de ithas barreiras; enquanto para o TSMA apresenta a equivalência entre laminitos algálicos ou grainstone oolítos (no topo da seqüência) com carvões de planície deltaica (no topo); mudstone/wackstone com boundstone/mudstone; além da correspondência óbvia entre folhelhos negros (SIM).

\subsection{O Gráfico de Fischer}

Fischer (1964) estudou os ciclos carbonáticos da plataforma alpina (Lofer Cyclothems) e os representou graficamente, mostrando a tendência de agrupamentos dos ciclotemas. Para Fischer (op. cit.) os ciclos foram considerados como tendo a mesma duração e depositados em condições de subsidência linear. Foram depositados no nível do mar ou acima dele, portanto não sofreram influência durante a deposição de variações eustáticas de maior ordem. Assim, o acréscimo de subsidência seria dado pela espessura de cada ciclo, e a linha que liga o topo de cada ciclo no gráfico poderia representar flutuações eustáticas. Na década de 80 passou a ser chamado de Gráfico de Fischer e amplamente utilizado no estudo de seções carbonáticas. Sadler et al. (1993) fornecem importantes informações sobre o uso deste método de análise de ciclicidade. Apesar da polêmica sobre o uso do Gráfico de Fischer como indicador de variações eustáticas ou de 
variação no espaço de acomodação a partir das espessuras dos ciclos (Boss \& Ramussen, 1995), eles são rotineiramente utilizados (Read, 1992). Read \& Goldhammer (1988) usam o gráfico para correlação de ciclos eustáticos de $3^{\text {a }}$ ordem. Backer (1997) considera que os gráficos mostram claramente os padrões de empilhamento dos ciclos, inclusive, para a Bacia do Solimões, eles fornecem indicações efetivas sobre controles alocíclicos que afetaram a sedimentação. Entretanto, chama a atenção para a necessidade de uma abordagem holística, integrando métodos e ferramentas interpretativas diversas para se obter a definição dos controles alocíclicos. Segundo Silva (1996), o Gráfico de Fischer para o Pensilvaniano da Bacia do Amazonas mostra a seguinte distribuição: no Morrovano e Atokano foram identificados dois ciclos de $3^{\text {a }}$ ordem (sintema I e II) e seis ciclos de $4^{a}$ ordem. A espessura dos ciclos de $3^{a}$ ordem variou de 25 a $47 \mathrm{~m}$. Para o Desmoinesiano foram identificados um ciclo de terceira ordem (sintema III) e cinco ciclos de quarta ordem.

Uma vez que a grande maioria dos ciclos de $3^{\mathrm{a}}$ e $4^{\mathrm{a}}$ ordem da Seqüência PermoPensilvaniana da Bacia do Parnaíba, da porção mais interior da bacia, é limitada por evaporítos pode-se considerar que a sedimentação do topo de cada ciclo ocorreu muito próximo do nível do mar, premissa básica para utilização do Gráfico de Fischer. Foram analisados os poços $3,6,8$ e 14 .

Os poços 3 e 6 situados, respectivamente, no norte e centro da Bacia do Parnaíba apresentam as melhores condições para aplicação do Gráfico de Fischer (Fig. 2.9 e Fig. 1.10.2). No poço 3 a porção evaporítica compreende quase todo intervalo e desde a base ocorrem carbonatos e camadas de anidrita. No poço 6 encontra-se uma importante contribuição siliciclástica na base da seção, mas ainda na porção inferior ocorrem camadas de anidritas e carbonatos. Foram identificadas duas seqüências de $2^{a}$ ordem, onde a primeira corresponde a toda Formação Piauí e parte significativa (mais de $50 \%$ ) da Formação Pedra de Fogo, com aproximadamente $390 \mathrm{~m}$ de espessura total. Compondo esta seqüência maior foram encontradas três seqüências de $3^{\mathrm{a}}$ ordem, onde as duas primeiras correspondem aproximadamente à Formação Piauí. A primeira, com $165 \mathrm{~m}$ de espessura, mostra um padrão de suave elevação no início da curva e brusca inflexão na porção superior. Esta seqüência é composta por três seqüências de $4^{a}$ ordem, na primeira identifica-se os TSMB e TST. Na seqüência dois ocorrem os TST e TSMA, e uma camada de anidrita que serve de limite. Também na seqüência três ocorre a repetição 
dos TST e TSMA, novamente limitados acima por uma camada de anidrita. A segunda seqüencia de $3^{\mathrm{a}}$ ordem, com espessura de $130 \mathrm{~m}$, que mostra suave inflexão na porção mediana da curva, é composta por três seqüências de $4^{a}$ ordem. A primeira seqüência mostra um padrão diferente das anteriores apesar de também ser formada por TST e TSMA. A porção inferior do TST pode ser dividido em duas seqüencias. É o que se denomina de seqüência compostas (composite sequence), também formadas por TST e TSMA, correspondendo a seqüência de $5^{\mathrm{a}}$ ordem. A seqüência 5 , de $4^{\mathrm{a}}$ ordem, apresenta o mesmo comportamento da anterior, diferindo apenas por apresentar espessura inferior. A seqüência seis, de $4^{a}$ ordem, encerra a seqüencia dois (de $3^{a}$ ordem). Apresenta um TST pouco desenvolvido em comparação com a maior espessura observada no TSMA, e também aqui encontra-se uma camada de anidrita finalizando a seqüência. $O$ padrão das sequêencias um, dois e três, de $3^{a}$ ordem, mostra uma diminuição progressiva das espessuras em direção ao topo, onde a seqüência três apresenta-se com espessura de apenas $95 \mathrm{~m}$. Ela é constituída por duas outras seqüências (sete e oito), que também mostram a tendência de diminuição de espessura para o topo. A primeira (seqüência sete, de $4^{a}$ ordem) com reduzido TST e significativo TSMA, é finalizada com uma espessa camada de anidrita nodular, como mostra o testemunho de sondagem 21 (Fig. 1.10.2). A segunda seqüência, de $4^{\mathrm{a}}$ ordem (oito), apresenta um TST pouco desenvolvido e um significativo TSMA, que se encerra com uma camada de anidrita que apresenta maior espessura que a anterior $(20 \mathrm{~m})$. Esta camada foi utilizada como datum na elaboração de seções litoestratigráficas e aloestratigráficas. O comportamento das sequiências restantes acima é similar ao já descrito para a porção inferior. Entretanto, ressalta-se o padrão de diminuição das espessuras em direção ao topo nas quatro seqüências de $3^{\mathrm{a}}$ ordem que apresentam, respectivamente, espessuras de $110 \mathrm{~m}, 145 \mathrm{~m}, 85 \mathrm{~m}$ e $75 \mathrm{~m}$.

0 poço 3 apresenta um padrão semelhante ao encontrado para o poço 6 , pelo menos para as seqüências de $2^{\mathrm{a}}$ e $3^{\mathrm{a}}$ ordens. Foram identificadas duas seqüências de $2^{\mathrm{a}}$ ordem, com $332 \mathrm{~m}$ e $355 \mathrm{~m}$ de espessura, que por sua vez são formadas por sete outras seqüências de $3^{\mathrm{a}}$ ordem. Enquanto no poço 6 são encontradas quinze seqüências de $4^{\mathrm{a}}$ ordem, no poço três elas somam 36. Esta diferença é creditada ao fato de terem sido usadas espessuras de conjuntos de parasseqüencias, na confeç̧ão do Gráfico de Fischer, para o poço 6 , enquanto para o poço 3 foram utilizadas espessuras de parasseqüências, respectivamente $78 \mathrm{~m}$ e $208 \mathrm{~m}$. Quanto maior o número de parasseqüências utilizadas maior será o detalhamento das inflexões das curvas. 
O poço 8, perfurado na porção NE da Bacia do Parnaíba, apresenta apenas uma seqüência de $2^{\mathrm{a}}$ ordem, com sua espessura coincidindo com a Formação Piauí (Fig. 5.7.1). Compondo esta seqüência foram identificadas cinco outras seqüências de $3^{\text {a }}$ ordem e vinte e quatro de $4^{\mathrm{a}}$ ordem. Aqui também foram utilizadas espessuras de parasseqüências, num total de 109. No item 7.1 foram discutidas as seqüências de menor ordem deste poço (páginas 97 a 99).

O poço 14 , situado na porção sul da bacia, essencialmente siliciclástico na sua base, mostra-se inadequado para determinação de ciclicidade e padrões de empilhamento pelo uso do Gráfico de Fischer. Provavelmente, a sedimentação na base do poço não seja cíclica. Apenas as seqüências de $2^{a}$ ordem podem ser correlacionáveis, nas demais ordens o padrão apresentado é distinto dos apresentados pelas outras seqüências até aqui identificadas.

\subsection{AS SEQÜÊNCIAS PERMO-PENSILVANIANAS DE $44^{\mathrm{a}}$ ORDEM}

Informações obtidas a partir do Gráfico de Fischer e do modelo de preenchimento da bacia evaporítica aqui proposto, permitiram montar um arcabouço crono-estratigráfico para as seqüências Permo-Pensilvanianas da Bacia do Parnaíba. Este modelo é carente de dados cronológicos, entretanto, a medida que surgirem novos dados o modelo poderá ser complementado. Foram construídas duas seções que correspondem, grosso modo, às formações Piauí (Seqüência Pensilvaniana) e Pedra de Fogo/Motuca (Seqüência Permiana), respectivamente. As seções estratigráficas, que cortam a bacia no sentido leste-oeste, foram construídas utilizando-se como datum uma camada de anidrita de extensão significativa (mais de $400 \mathrm{~km}$ ), que ocorre acima do contato entre as formações Piauí e Pedra de Fogo. Na porção mais interior da bacia as superfícies limite de seqüência mostram uma excelente correlação, permitindo montar o arcabouço temporal para seqüências de $4^{\mathrm{a}}$ ordem.

A seqüência Pensilvaniana (Fig. 1.10.3) é formada por onze seqüências de $4^{a}$ ordem, consideradas também as seqüências compostas. Normalmente, não apresentam grande variações de espessuras na calha central, mas mostram afinamento para as bordas, principalmente em direção oeste. As seqüências compostas são as que mais se adelgaçam em direção as bordas, entre os poços 6 e 5, na borda oeste, e entre os poços 7 e 8 , na borda leste, progradam em onlap sobre as superficies limitantes inferiores. 


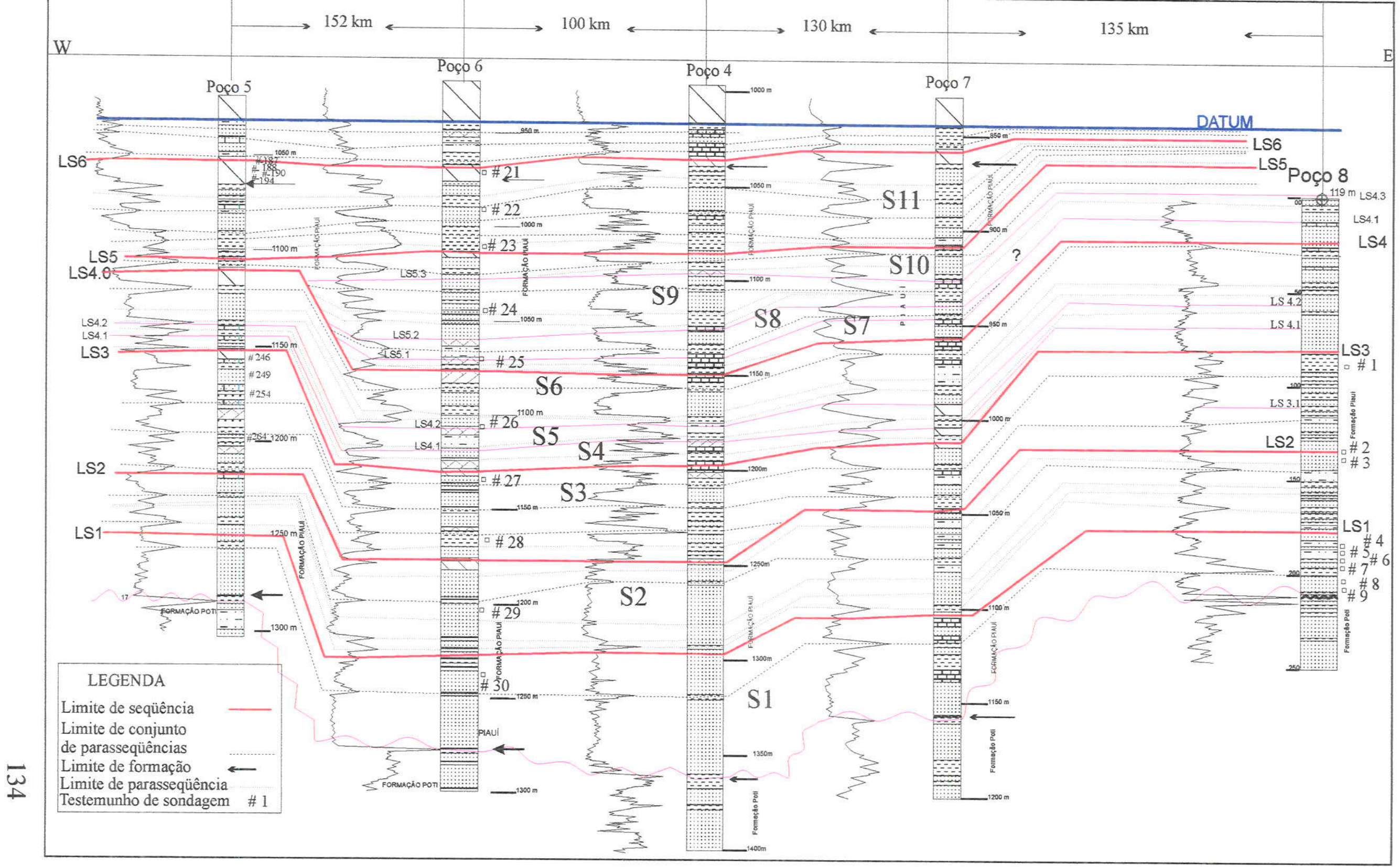

Fig. 2.10.2 - Seção estratigráfica leste-oeste da Bacia do Parnaíba, restrita às rochas da Formação Piauí, onde são apresentadas as unidades aloestratigráficas propostas para esta seção. Consistem de sequeências de 4a. ordem. O datum é uma camada de anidrita de ocorrência em toda porção central da bacia. 
Dentro das seqüências de $4^{a}$ ordem são ainda correlacionáveis parasseqüências e conjuntos de parasseqüências. A disposição espacial destas superfícies mostra que podem estar envolvidos hiatos significativos em algumas regiões da bacia, por exemplo, nas imediações do poço 5. Ou, menos provável, ocorram ali seções condensadas. A seqüência um, depositada acima da superfície discordante que separa as rochas sedimentares depositadas no Mississipiano daquelas depositadas no Pensilvaniano, apresenta apenas rochas siliciclásticas ao longo da seção estratigráfica (leste-oeste), exceto no poço 7 (carbonatos) perfurado a nordeste da bacia. Em direção ao norte apresenta-se com influência carbonática e evaporítica. A seqüência dois apresenta uma geometria tabular, característica das seqüências depositadas em bacias intracratônicas, limitadas acima por carbonatos de TSMA na borda oeste e centro-nordeste, evaporitos na porção central e depósitos eólicos na porção nordeste (TSMB), como mostram os testemunho e perfis compostos. A seqüência três também apresenta uma geometria tabular, mostra-se menos siliciclástica e apresenta como limite superior carbonatos e evaporitos distribuídos ao longo da bacia, exceto no poço 8 , marcado por espessos depósitos eólicos. A sequiência 4 (sequêencia composta) é constituída por três outras seqüências. Todas limitadas por evaporitos e carbonatos na porção central da bacia e depósitos eólicos na borda leste, exceto a última, que também apresenta depósitos carbonáticos como limite superior. Com comportamento semelhante a anterior, a seqüência 5, que é constituída por cinco seqüências de menor ordem, também é limitada acima por carbonatos e evaporitos. Não ocorrendo na borda leste, como todas seqüências acima. Considerada como a última seqüência do Pensilvaniano, é limitada por espessa camada de anidrita. Aqui, a bacia mostra uma significativa expansão, em relação às quatro seqüências depositadas anteriormente.

A seqüência Permiana apresenta dez seqüências de $4^{\mathrm{a}}$ ordem, também com ótima correlação entre as superfícies limitantes (Fig.2.10.3). A primeira seqüência (ou sétima da Seqüência Permo-Pensilvaniana) apresenta-se fina e estreita limitada por uma espessa camada de anidrita utilizada como datum. Chama a atenção na seqüências dois (ou oito), o forte padrão retrogradacional do TST, (semelhante ao da seqüência 3) evidenciando a expressiva subida do nivel relativo do mar, responsável pelo desenvolvimento de superfícies de máxima inundação marinha de fácil correlação no âmbito da bacia e, provavelmente, regional. É limitada por carbonatos e anidrita, restrita ao poço 7 na borda leste. Já a seqüência três, semelhante a anterior, apresenta menor espessura e inversão 


\section{SEÇÃO ESTRATIGRÁFICA LESTE-OESTE}

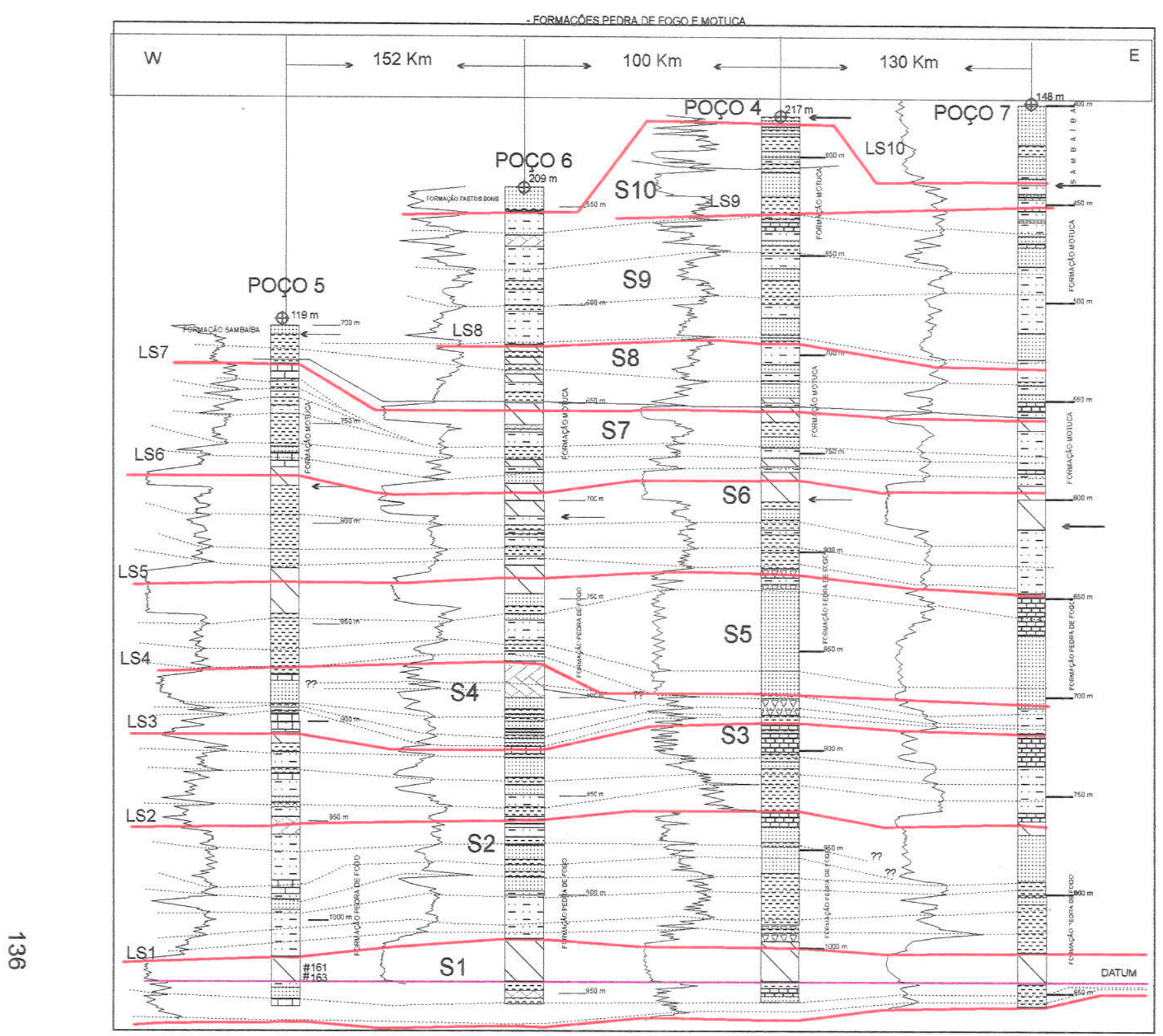

Fig. 2.10.3 -Seção estratigráfica leste-oeste mostrando as dez seqüências de 4a. ordem do Permiano da Bacia do Parnaíba. No texto são apresentadas explicação. 
na posição da camada de evaporito, presente no limite superior a oeste (poço 5). A seqüência quatro, apresenta-se com geometria de lençol, limitada por calcários na borda oeste, dolomitas na porção central da bacia e depósitos eólicos na borda leste. A seqüência cinco apresenta depósitos eólicos de TSMB, na borda leste, e expressivos depósitos pelíticos na borda oeste. É limitada por camadas de anidrita na borda oeste, e carbonatos na borda leste. As seqüências cinco, seis e sete mostram-se com grande influência evaporítica, restrita a presença de depósitos arenoso, interpretados como eólicos de TSMB. A seqüência seis ocorre com pouca espessura, limitada a porção central da bacia, com limites definidos em camadas de anidrita e siltitos. A seqüencia sete apresenta intercalações de camada de anidrita com siltito e argilito, é limitada por evaporitos na porção central e borda leste, enquanto ocorrem carbonatos na borda oeste (poço 5). Mal definida, a provável seqüência oito, está restrita aos poços 6,4 e 7, limitada por anidrita na borda oeste e siltito na borda leste. A seqüência nove apresenta aumento de espessura em relação as duas anteriores, ocorrendo também restrita aos poços $6,4 \mathrm{e}$ 7, limitada por dolomitas (borda oeste) e calcários. A última seqüência tem seu limite superior marcado pelo contato erosivo com as formações Sambaíba e Pastos Bons.

As relações espaciais entre as superficies que delimitam as seqüencias de $4^{\mathrm{a}}$ ordem na seção estratigráfica leste-oeste, sugerem que a bacia experimentou uma fase de expansão inicial, representada pelas seqüências de 1 a 6 , seguidas de uma fase de retração, quando foram depositadas as seqüências 7, 8 e 9 . Em seguida houve nova fase de expansão.

10.4 COMPARAÇÃO ENTRE AS SEQÜENCIAS ENCONTRADA E OUTRAS DE MESMA IDADE COM PERIODICIDADE CONHECIDA

As seqüências de Quarta ordem tem sua origem atribuída aos ciclos de excentricidade de curta e longa duração. Apesar de não terem sido obtidas idades para as seqüências do Permo-Pensilvaniano da Bacia do Parnaíba, é possivel comparar as seqüências aqui identificadas com outras sucessões, cíclicas, com periodicidades estimadas.

As sucessões que mais se aproximam são as freqüências de $4^{\mathrm{a}}$ ordem de Becker (1997), encontradas no Permo-Carbonífero da Bacia de Solimões. Já que as duas bacias encontram-se no mesmo contexto intracratônico, a sedimentação é predominantemente 
carbonático-evaporítica e a abordagem da Estratigrafia de Seqüências foi utilizada nos dois trabalhos. Becker (op. cit.) obteve idades que variam de 114 a 456 mil anos para as seqüências de $4^{\mathrm{a}}$ ordem. Ele identificou nove seqüências de $4^{\mathrm{a}}$ ordem.

Outro estudo semelhante, embora com abordagem diferente, foi realizado por Silva (1996) para a Bacia do Amazonas. Neste trabalho foram utilizados os conceitos de cicloestratigrafia. Equivalentes as seqüências de $4^{a}$ ordem, os megaciclotemas possuem duração estimada entre 97 e 340 mil anos.

As seqüências de $4^{a}$ ordem podem também ser comparadas aos ciclotemas tipo kansas (235 e 393 mil anos, Heckel, 1986), ou às seqüências do Desmoinesiano de Ross \& Ross (1988) com duração de 390 mil anos.

A causa deste ciclos é justificada por movimentos glácio-eutáticos corroborando a interpretação de Crowell (1979) segundo a qual as variações eustáticas estão relacionadas ao avanço e retração de diversos centros glaciais situados no Gondwana. As bacias do Solimões, Amazonas e Parnaíba estavam situadas num contexto climático diferente das outras bacias do Gondwana, durante o final do Carbonífero. Além do que, é provável, que elas mantivessem alguma ligação, mesmo que esporadicamente, durante os pulsos marinho mais forte (Fig. 3.10.3 e Fig. 4.10.3).

A estratigráfia em bacias cratônicas pode ser realizada com o uso dos conceitos e técnicas derivadas do desenvolvimento da Estratigrafia de Seqüências. Vários artigos publicados no Brasil (p.e. Castro, 1995, 1996; Canuto, 1997; Canuto et al., 1997) mostram a vantagem de se utilizar a nova abordagem estratigráfica sobre a Estratigrafia Tradicional pela possibilidade de se montar um arcabouço crono-estratigráfico, no qual permite-se correlação mais refinadas. 


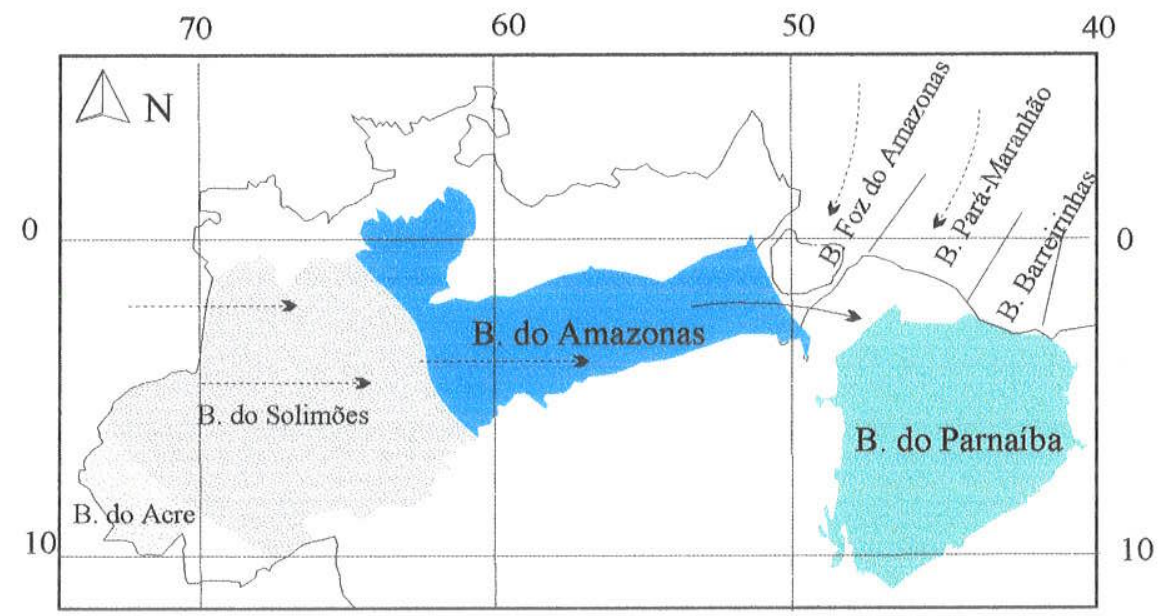

Fig. 3.10.3- Mapa de localização das bacias do Parnaíba e Amazonas. As setas de linhas contínuas mostram a provável ligação entre as bacias, durante o Permo-Pensilvaniano, enquanto as setas descontínua sugerem as possíveis entradas do mar . 


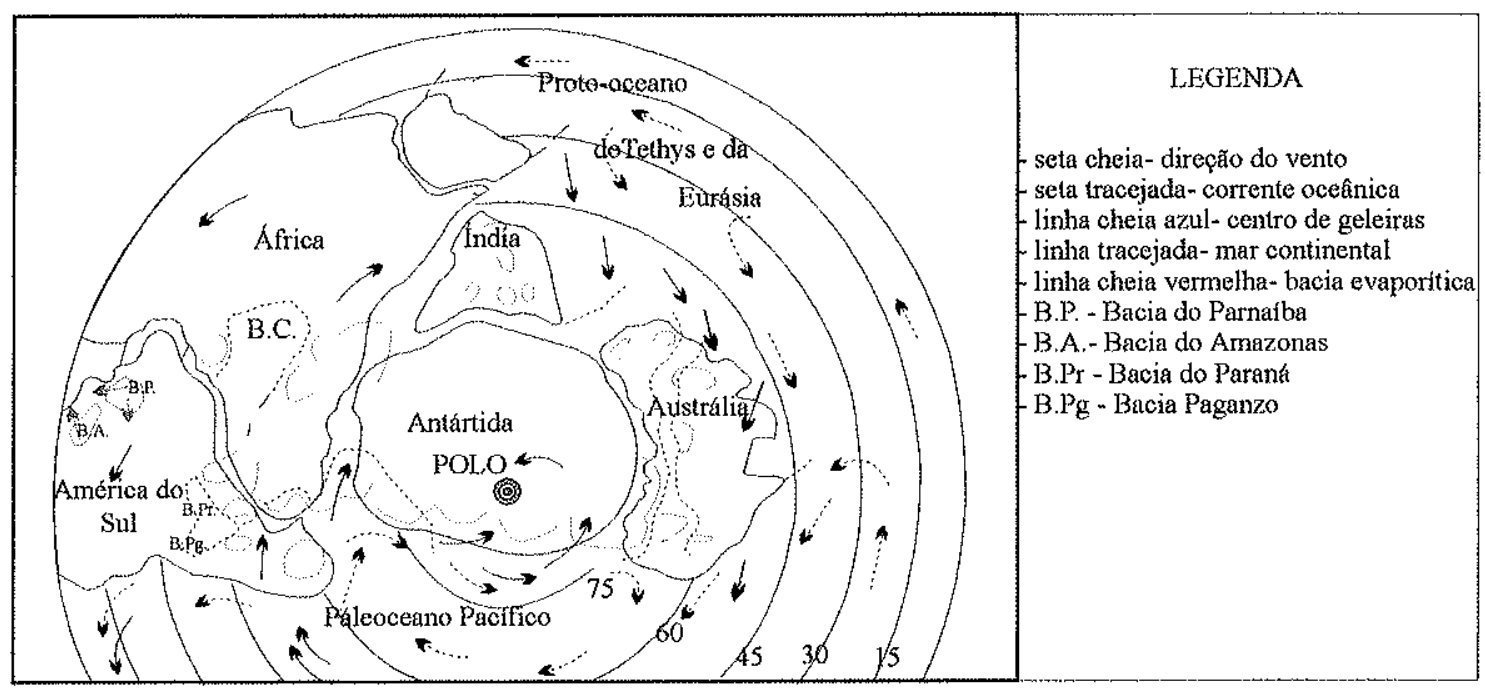

Fig.4.10.3 -A posição do Gondwana durante o final do Carbonífero, ressaltando-se o contraste climático entre as grandes bacias paleozóicas brasileiras. Nas bacias do Parnaíba e Amazonas eram depositados evaporitos de clima quente e árido enquanto a Bacia do Paraná sofria influência glacial. (Modificado de Crowell, 1978 com dados de Lanzarini, 1984 e Lima Filho, 1991). 


\section{1- CONCLUSÕES}

1- Os conceitos da Estratigrafia de Seqüências são perfeitamente adaptáveis e aplicáveis na construção de um arcabouço crono-estratigráfico para as seqüências permo-pensilvanianas da Bacia do Parnaíba.

2- A arquitetura estratigráfica encontrada mostra-se composta de várias ordens de ciclos.

3- O limite de seqüência que separa as rochas da Formação Poti e Piaui, seqüência mississipiana e pensilvaniana, respectivamente, é do tipo 1.

4- Os TST e TSMA são os tratos de sistemas que comumente compõem as seqüências de $4^{\mathrm{a}}$ e 5 ordens.

5- Os TSMB são raros, ocorrendo na base da primeira seqüência e esporadicamente quando há criação de espaço de acomodação adicional, geralmente envolvendo depósitos eólicos.

6- A glacio-eustasia é, provavelmente, o mecanismo responsável pelo desenvolvimento das seqüencia permo-pensilvanianas da Bacia do Parnaíba.

7- As correlações entre as seqüências identificadas no Permo-Pensilvaniano da Bacia do Parnaiba e outras de mesma idade e ordem, na Bacia do Amazonas, Solimões, ou no continente americano são imprecisas, devido a falta de um zoneamento bioestratigráfico preciso. Entretanto, a partir da proposta de arcabouço aqui apresentada é possivel afirmar que existem uma forte afinidade entre as seqüencias de $3^{a}$ ordem e provavelmente $4^{a}$ ordem, nas bacias do Solimões, Amazonas e Parnaíba. 


\section{ESTAMPA 1}

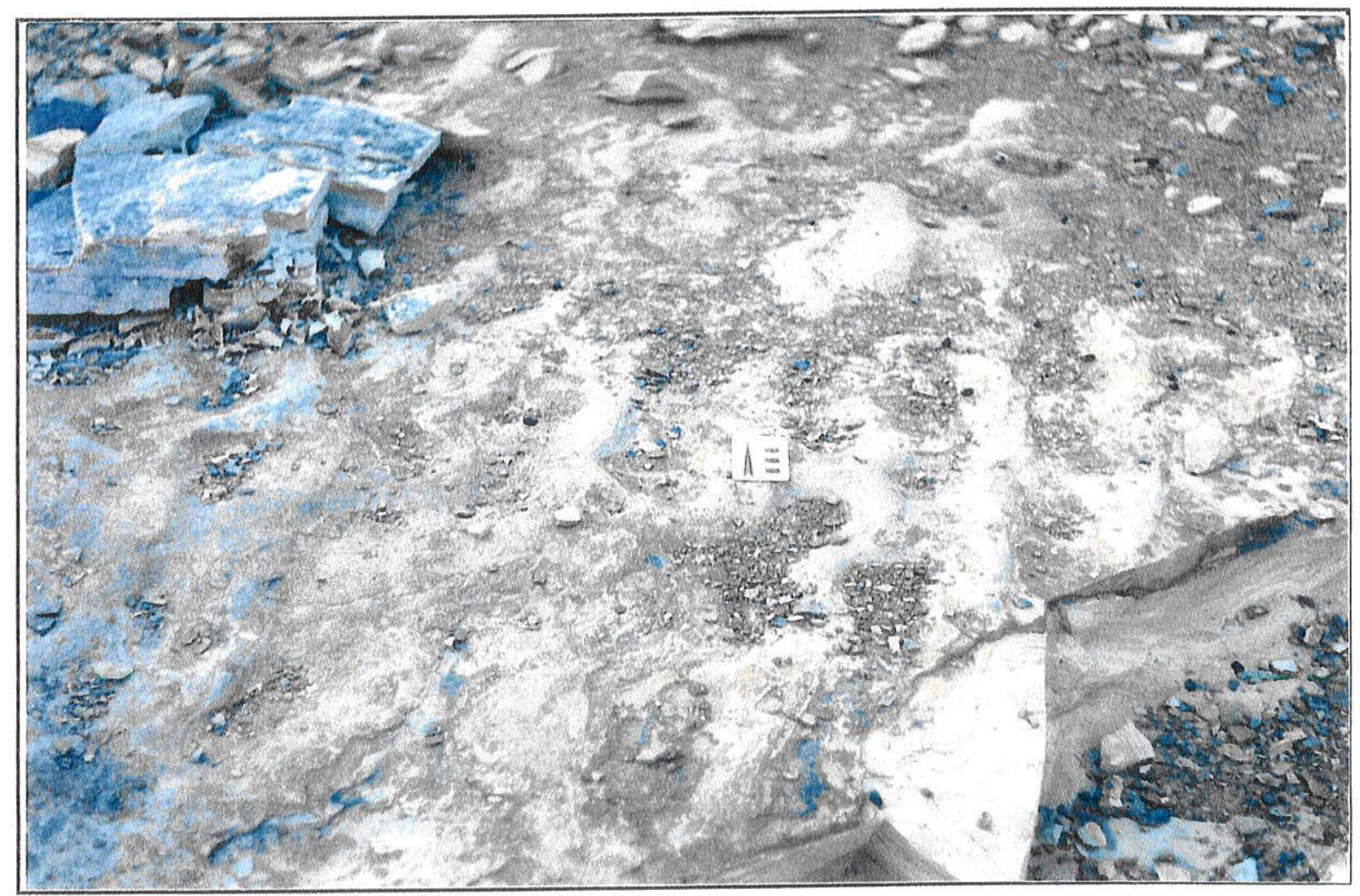

Foto 2- Pacotes de lamitos com lobos de suspensão ocorrem separados por superfícies bioturbadas, com marcas onduladas.

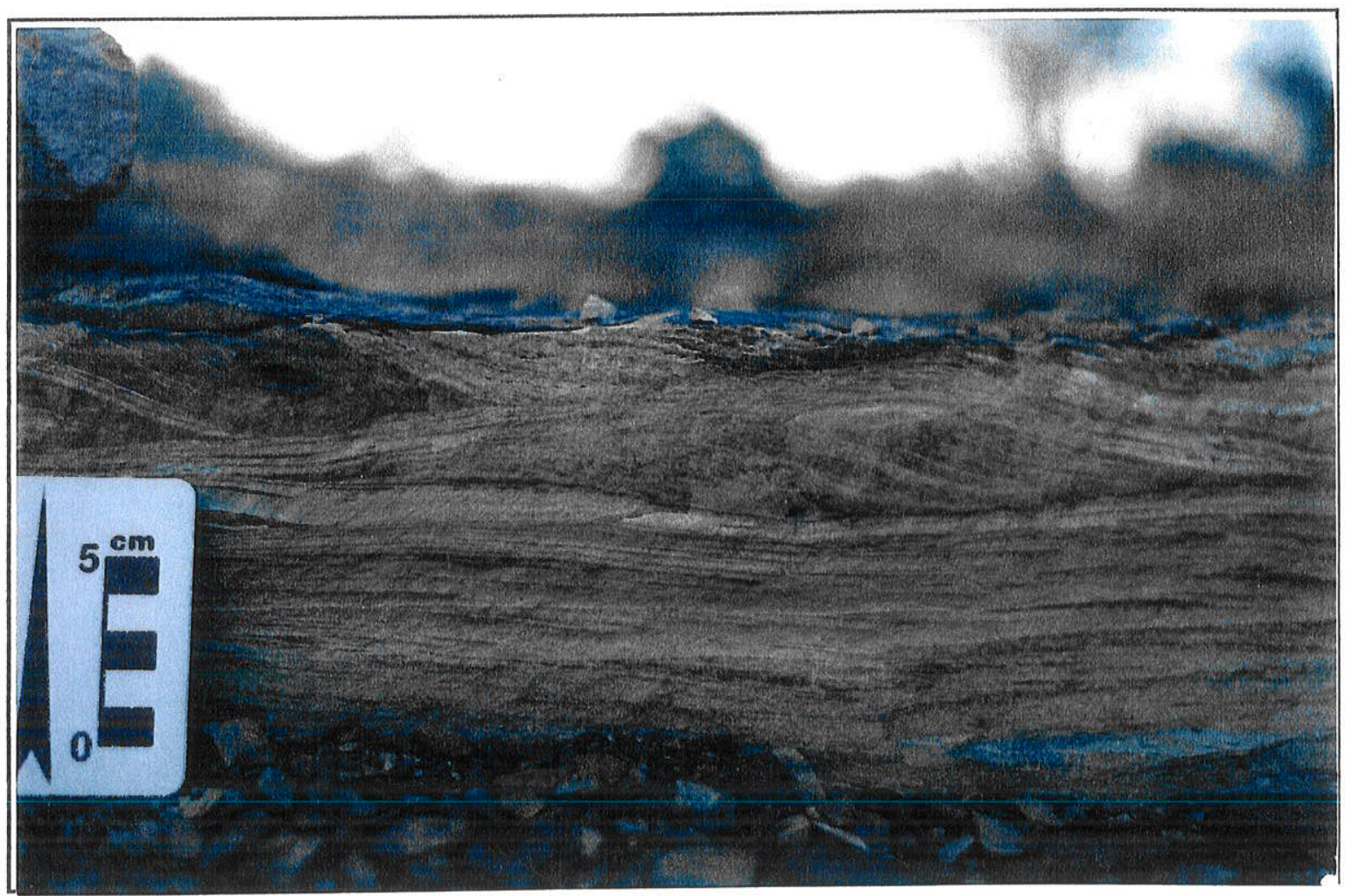

Foto 1- detalhe dos lobos de suspensão da seção colunar de Santa Rita exibindo laminação clinoforma. 


\section{ESTAMPA 2}
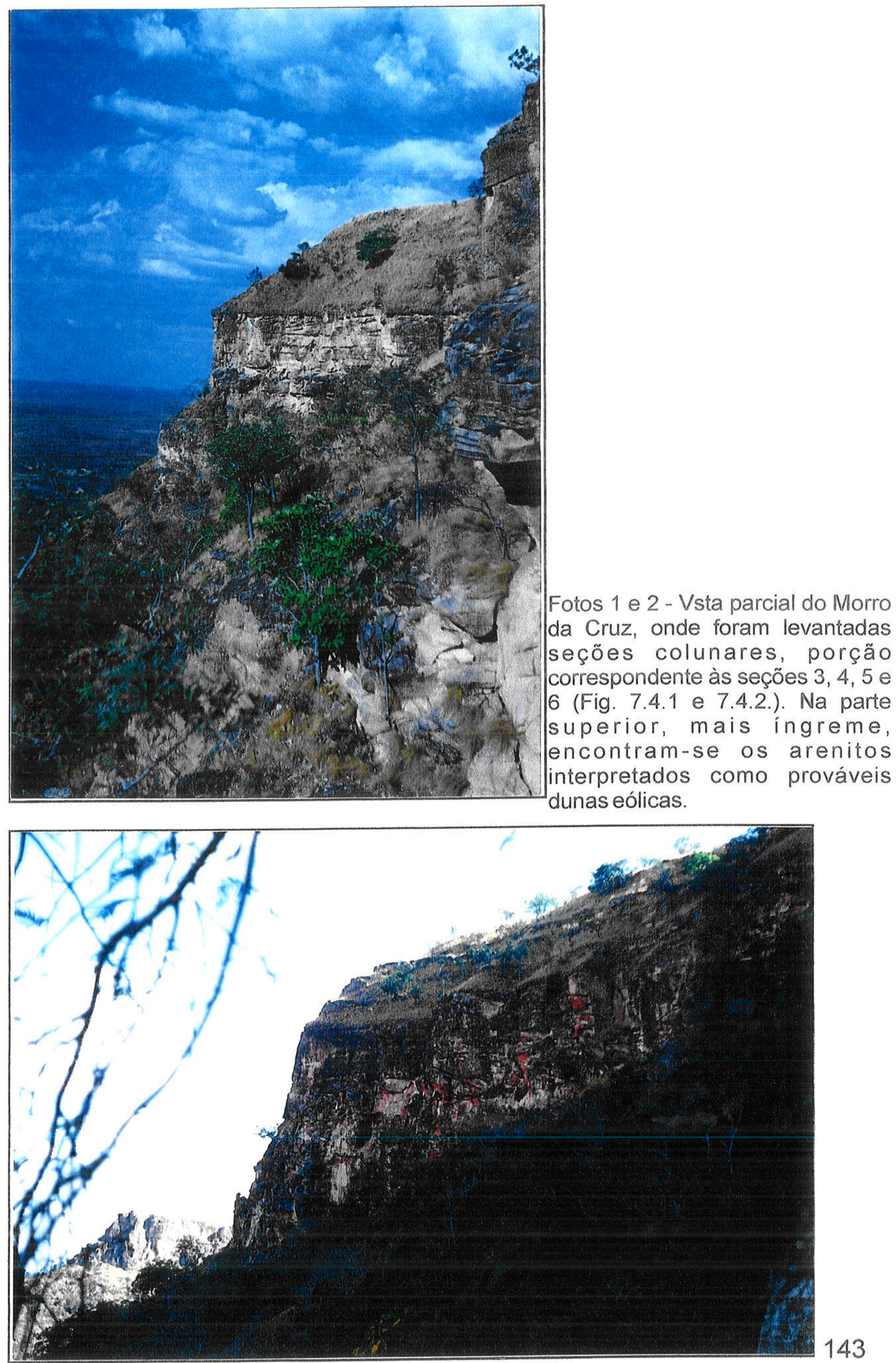


\section{ESTAMPA 3}

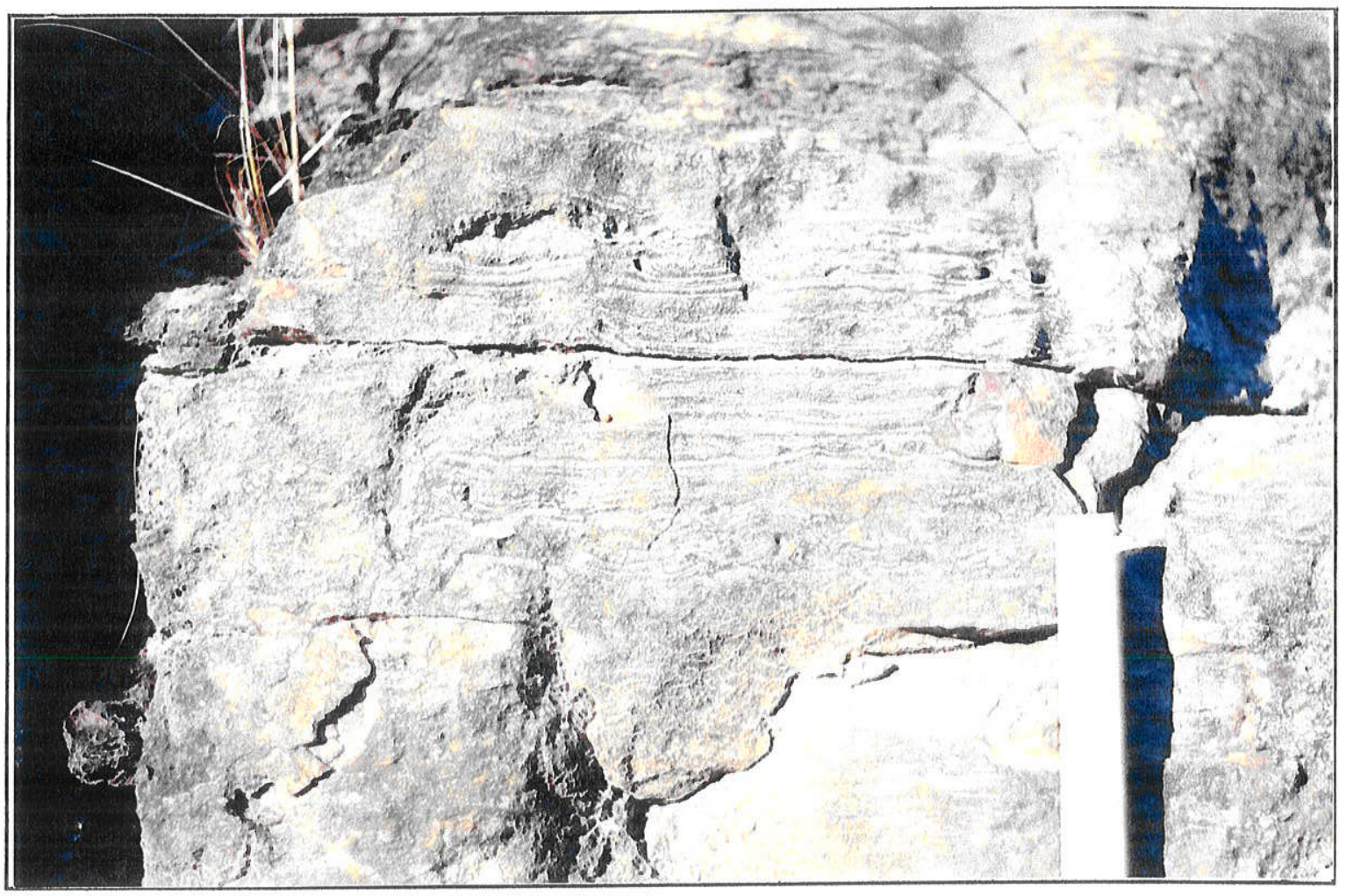

Foto 2- Arenito com dobras atectônicas e estratificações cruzadas de baixo ângulo interpretado como prováveis depósitos de praia. Estão posicionados acima dos arenitos com guttercast.

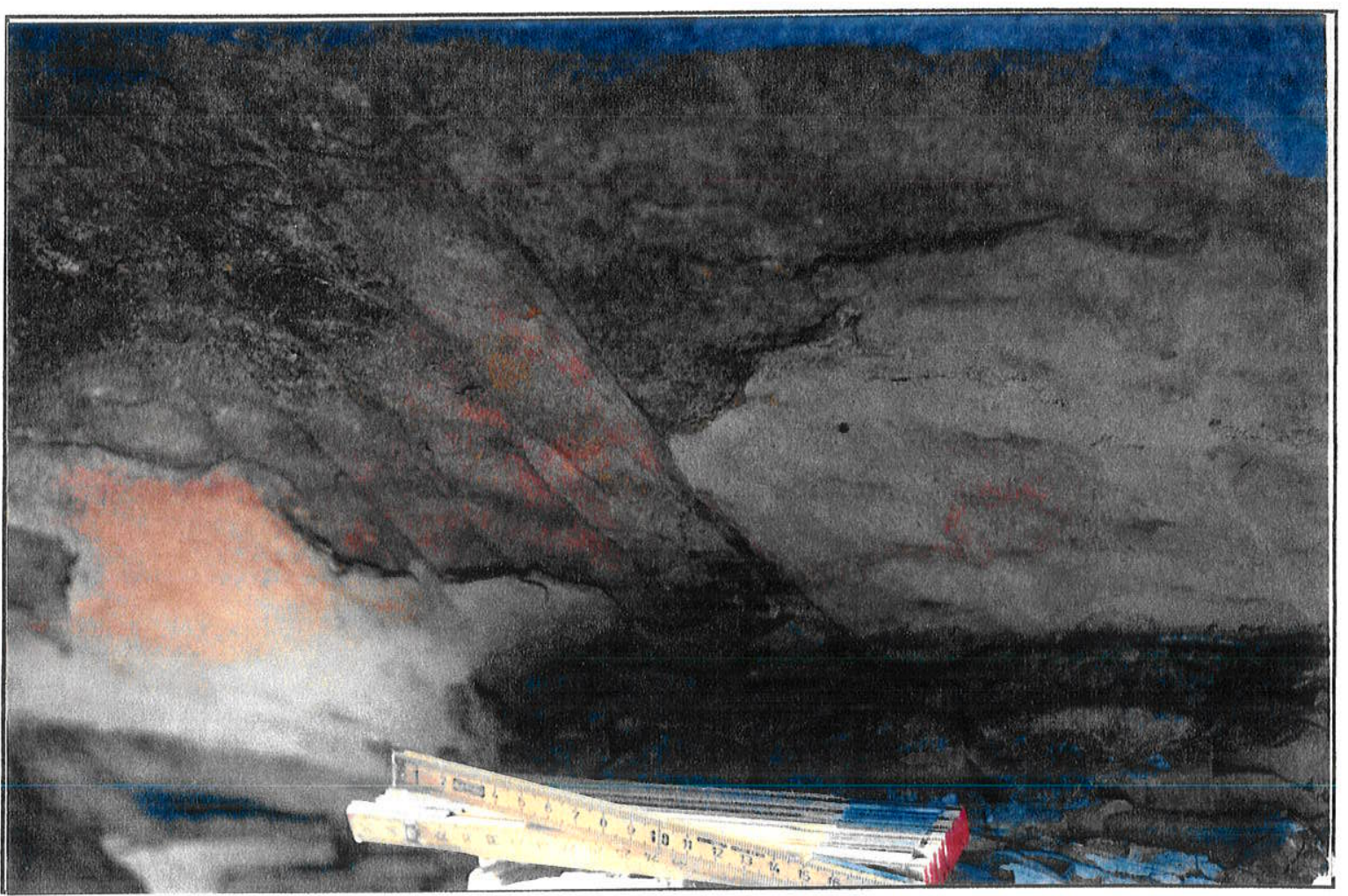

Foto 1- Arenito com gutter cast na base, num contexto de plataforma retrabalhada por ondas de tempestade, na seção colunar da Baixa Fria. 
ESTAMPA 4

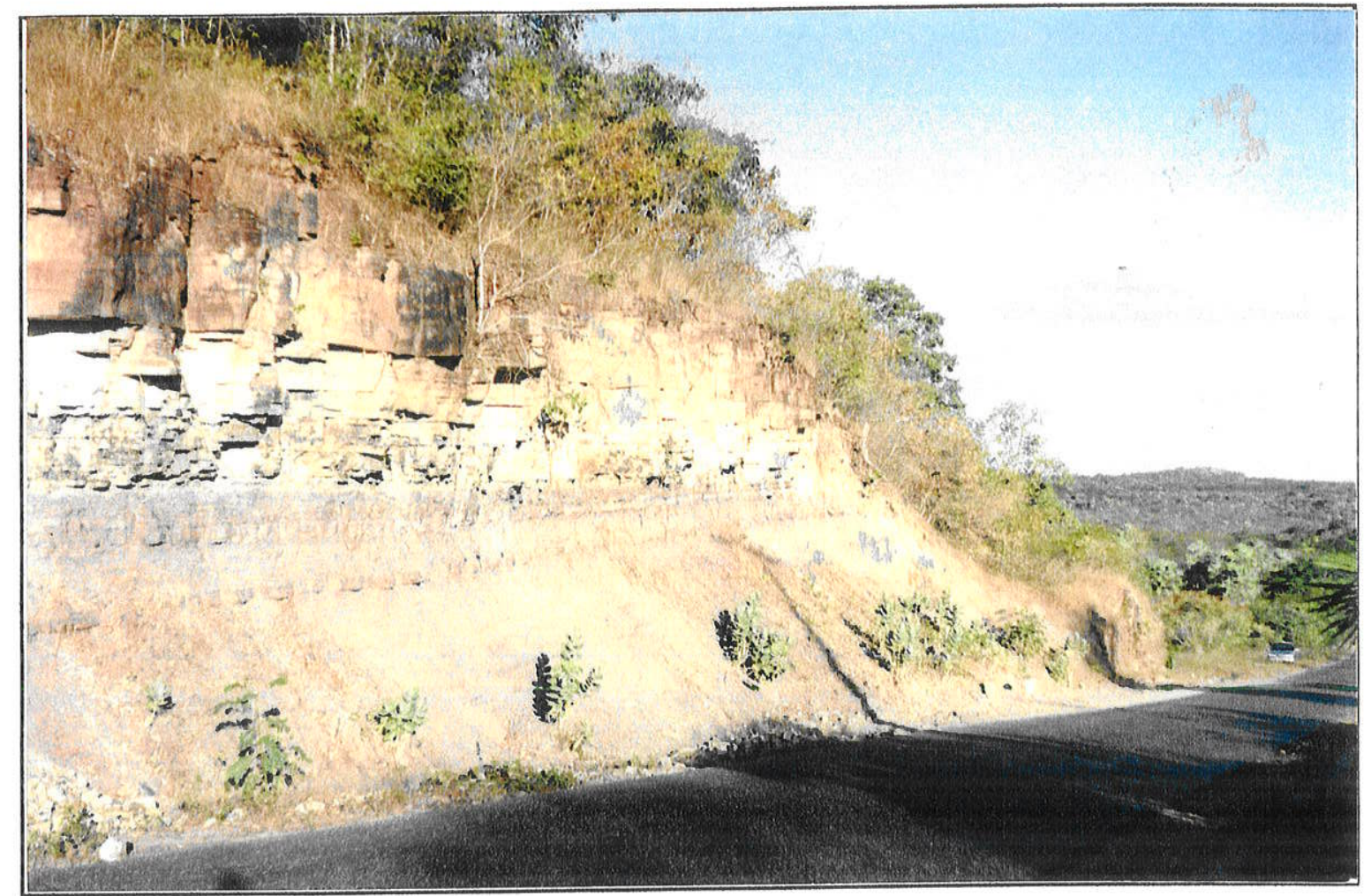

Foto 2- Detalhe da fotografia anterior onde podem ser vistos os folhelhos interpretados como superfície de máxima inundação marinha do primeiro TST da Seqüência Permo-Pensilvaniana da borda leste da Bacia do Parnaíba.

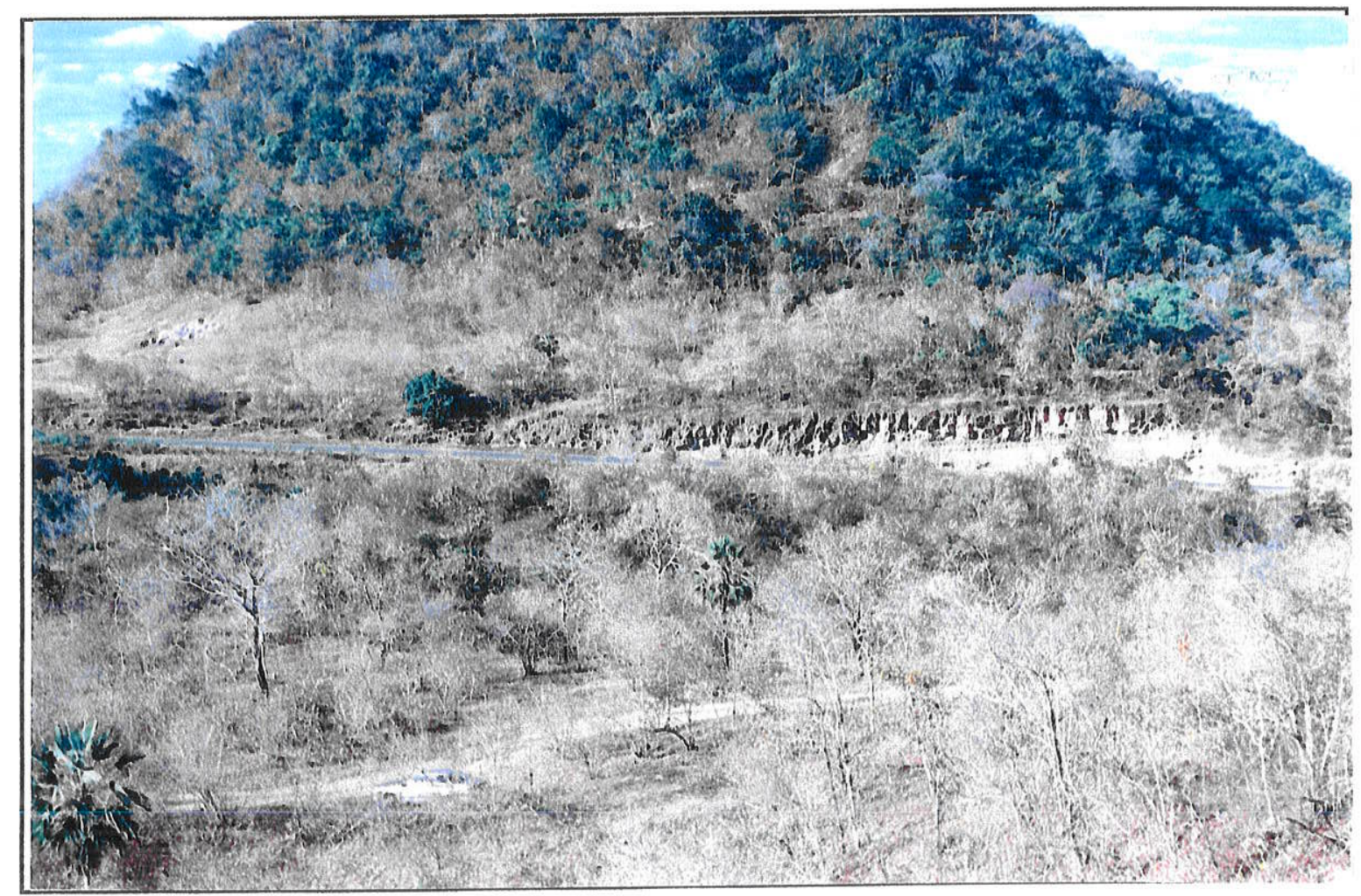

Foto 1- Vista parcial do afloramento onde foi levantada a seção colunar da Baixa Fria. No conto inferior direto ocorrem depósitos interpretados como possíveis registros do TSMB. Acima, em contato, folhelhos de plataforma retrabalhada por ondas de tempestade que representam a superfície de máxima inundação marinha. 


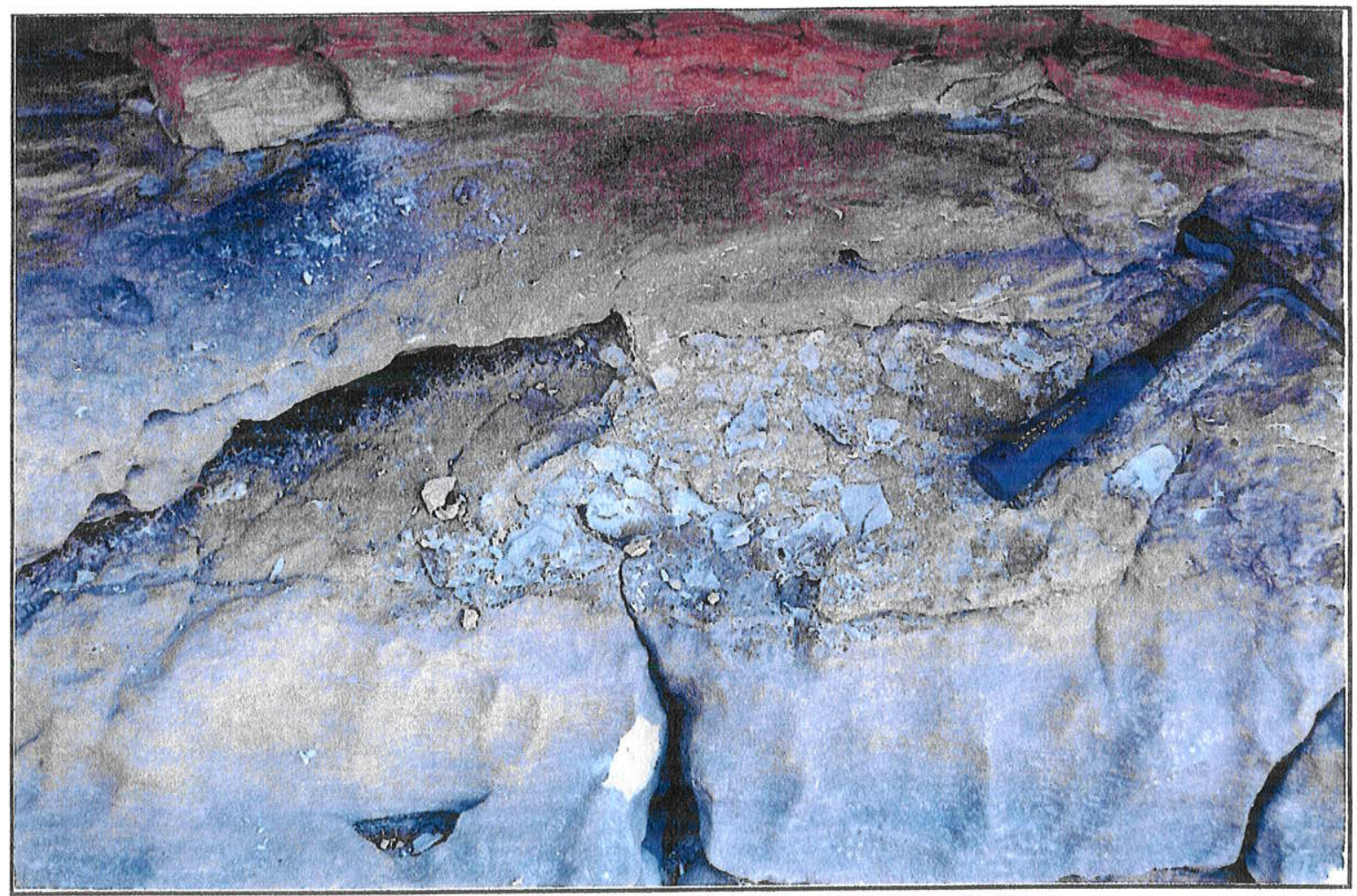

Foto 2- Detalhe do afloramento abaixo, mostrando a superfície erosiva, os clastos de argila achatados e fragmentos líticos.

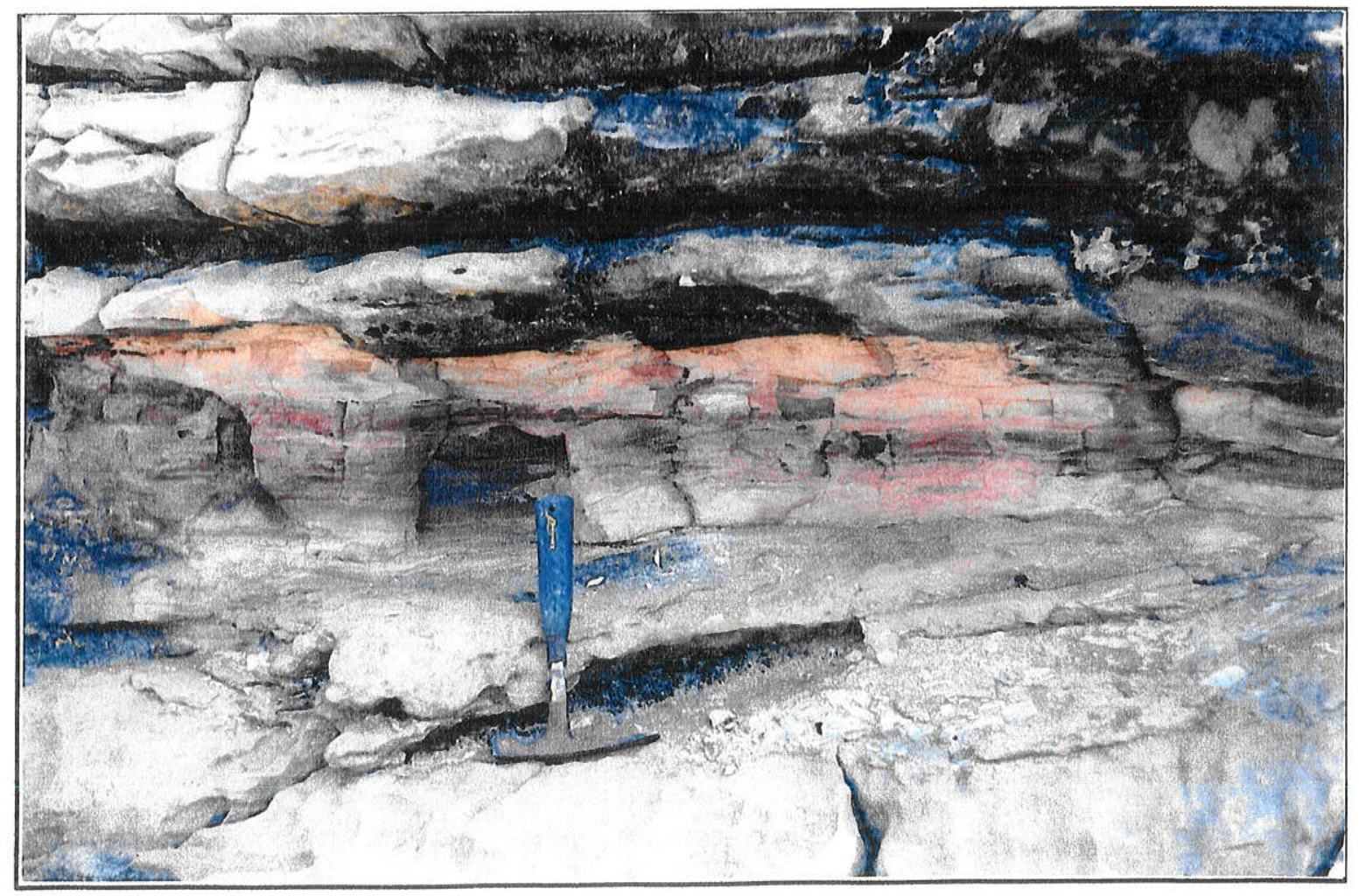

Foto 1- Superfície transgressiva que marca a passagem do TSMB para o TST na seção colunar Alegria. 


\section{ESTAMPA 6}

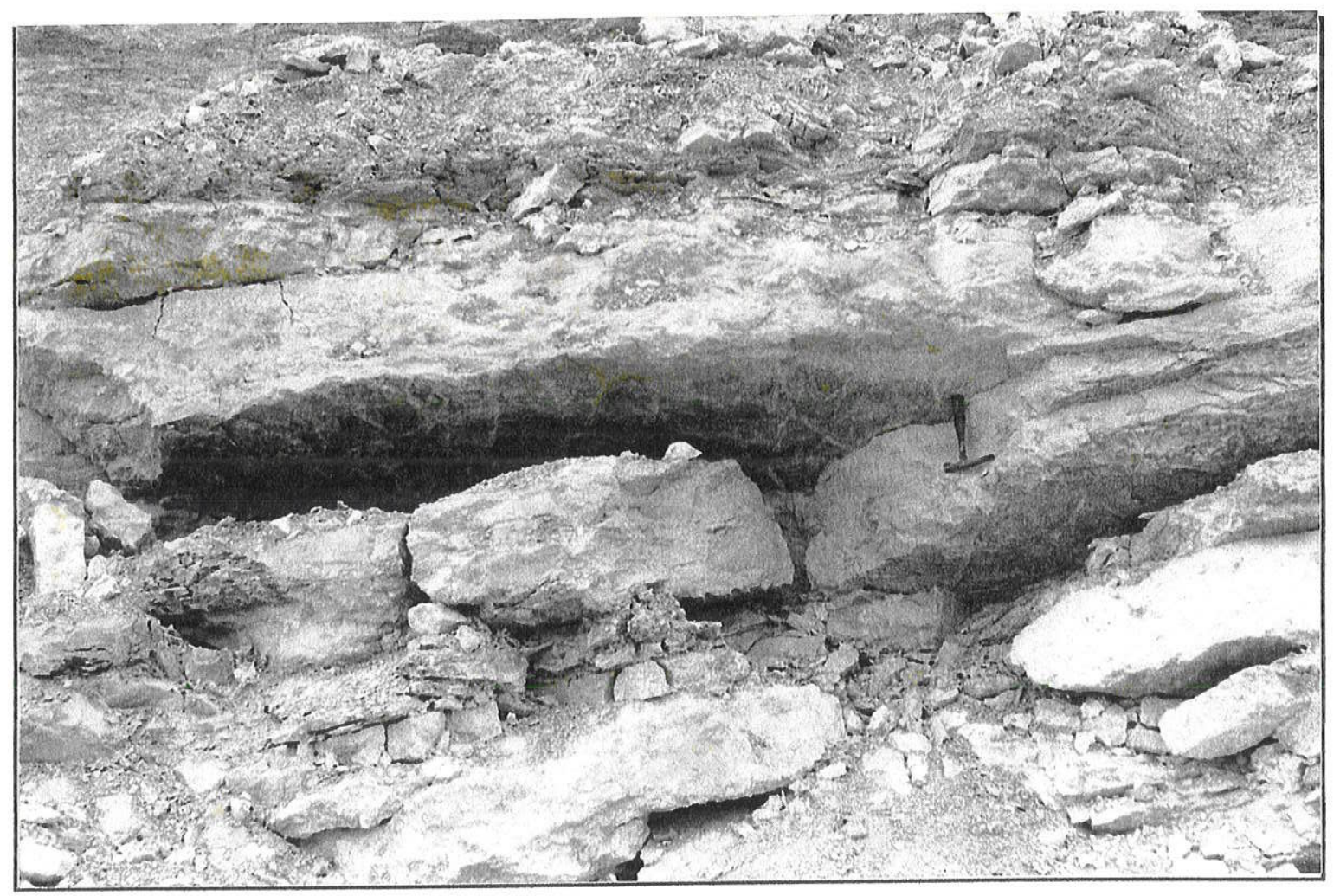

Foto 2- Detalhe das gretas de contração que ocorrem acima dos carbonatos, semelhante ao que acontece na borda leste da Bacia do Parnaíba nos calcários da região de José de Freitas no Piauí.

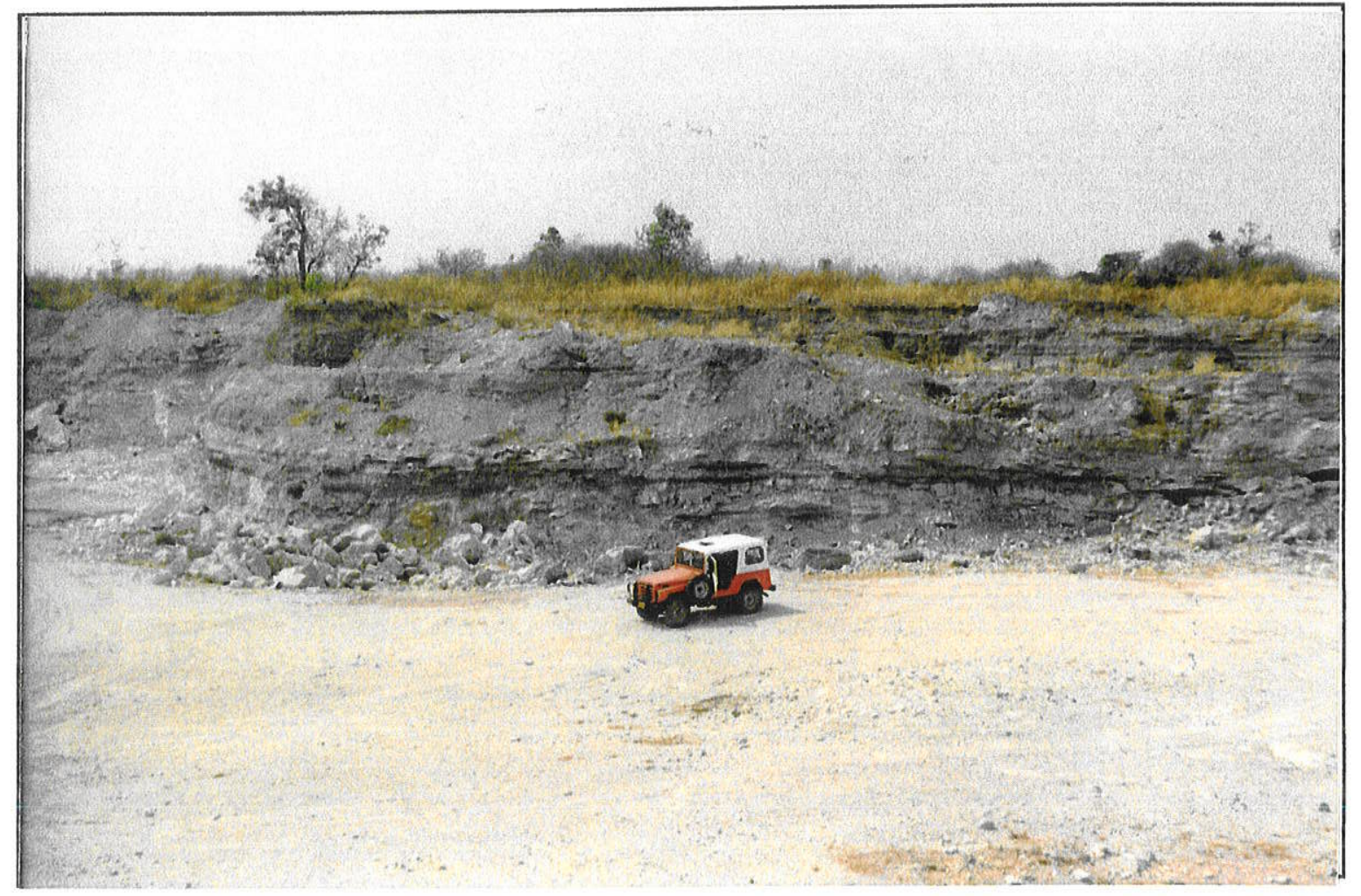

Foto 1- Vista geral da frente de lavra da Mineração Jota Demito, em Riachão, MA na borda oeste da bacia. Os carbonatos da Formação Pedra de Fogo ocorrem no nível do chão onde está o jeep. 


\section{ESTAMPA 7}

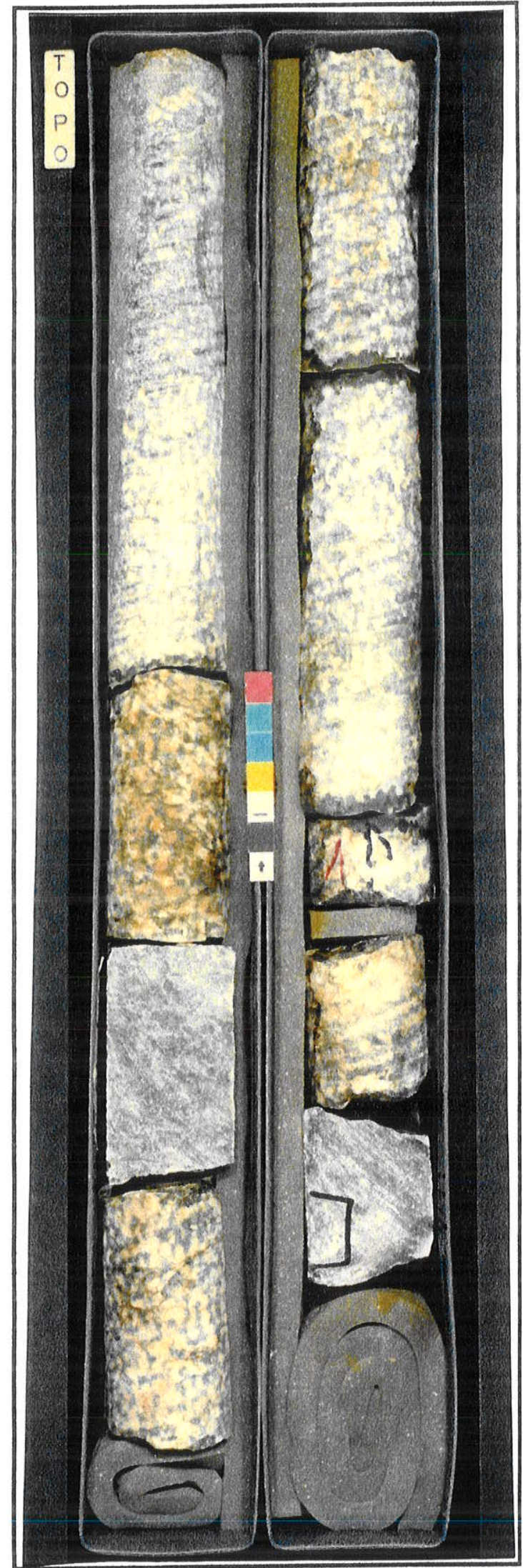

Foto 1- Testemunho de sondagem do poço 6, mostrando anidrita nodular, interpretada como depósito de sabkha, onde situa-se o limite das seqüências pensilvanianas de $4 a$. ordem de número 6 e 7. 


\section{3- REFERÊNCIAS BIBLIOGRÁFICAS}

*Abreu, F.A.M.; Silva,; J.M.R.; Faria Jr., L.E.C.; Rodrigues, M.D.R.; Truckenbrodt, W. 1977. Projeto Balsas. Belém, Relatório Final, Convênio DNPM/UFPA, 47p.

* Aguiar, G.A. 1971. Revisão geológica da bacia paleozóica do Maranhão. In: SBG, Congresso Brasileiro de Geologia, 25, São Paulo, 1971. Anais, 3:113-122.

Aigner, T. 1982. Calcareus tempestites: storm-dominated stratification in Upper Muschelkalk limestones(Middle Trias, SW Germany). In: Einsele G.; Seilacher A.(eds.). Ciclic and event stratification. Spring, Berlin Heidelberg New York, 180-198.

Aigner, T. 1985. Storm depositional systems. In : G. M. Friedman. et al. (ed). Lectures Notes in Earth Sciences. Berlin, Springer-Verlag. $174 \mathrm{p}$.

Alam, M.M.; Crook, K.A.W.; Taylor, G.M. 1982. Herring bone cross stratification in modern fluvial sediments. Coonamble, NSW Australia, Hamilton, Canada, Abstr. 11 Congress on Sedimentology, p. 147.

Albuquerque, O. R. de; Dequech, V. 1946. Contribuição para a geologia do meio-norte, especialmente Piauí e Maranhão, Brasil. In: Congresso Pan-Americano de Engenharia de Minas e Geologia, 2, Petrópolis,. Anais, 3:69-109.

Allen, J.R.L. 1981. Lower Cretaceous tides revealed by cross-beding with mud drapes. Nature, 289:579-581.

Anderton, R. 1985. Clastic facies models and facies analysis. In: Brenchley, P.J.; Williams, B.P.J. (eds.). Recent developments and Apllied Aspects. Geological Society. Blackwell Scientificic Publication, Oxford, 31 47.

Andrade, S.M. de; Daemon, R.F.1974. Litoestratigrafia e bioestratigrafia do flanco sudeste da Bacia do Parnaíba (Devoniano e Carbonífero). In: SBG, Congresso Brasileiro de Geologia, 28, Porto Alegre, 1974, Anais... Porto Alegre, 2:129,137.

Anelli, L.E. 1994. Pelecípodes da Formação Piauí (Pensilvaniano Médio), Bacia do Parnaíba, Brasil. Instituto de Geociências, USP, São Paulo, Dissertação de Mestrado, 148 p.

* Anelli, L.E., Rocha-Campos, A.C. Lima Filho, F.P. 1992. Paleoecologia dos bivalves da Formação Piauí (Neocarbonífero), Bacia do Parnaíba. 37 Congr. Bras. Geol., São Paulo, Boletim de Resumos Expandidos, 502.

4 * Anelli, L.E.; Simões, M.G.; Lima Filho, F.P. 1993. Análise tafonômica da assembléia de bivalves do Calcário Mocambo, Formação Piauí (Neocarbonífero) do Parnaíba. In: SBP, Cong. Bras. Paleontologia. São Leopoldo, Resumos, p 108.

Assis, J.F.P. 1980. Sobre uma fáunula de molusco bivalves do Calcário Mocambo. Carbonífero da Bacia do Maranhão. Anais da Academia Brasileira de Ciências. 52:201-202.

Batista, B.M; Braun, O.P.G.; Campos, D.A. 1984. Léxico Estratigráfico do Brasil. DNPM/MME, Brasília, 560 p.

Becker, C.R. 1997. Estratigrafia de seqüências aplicada ao Permocarbonífero da Bacia do Solimões, Norte do Brasil. Instituto de Geociências, UFRGS, Porto Alegre, Dissertação de Mestrado, 363 p.

Beurlen, K., 1965. Observações no Devoniano do Estado do Piaúi. Anais da Academia Brasileira de Ciências, 37:61-67.

Bigarella, J.J. 1973. Paleocorrentes e deriva continental. Boletim Paranaense de Geociências, 31:141-224.

Brito Neves, B.B. 1983. O mapa geológico do nordeste oriental da Brasil - Escala 1:1.000.000. Instituto de Geociências, Universidade de São Paulo, São Paulo, Tese de Livre Docência, 177 p.

Brito, I.M. 1969. Os acritarcha e sua utilização na estratigrafia Siluriana e Devoniana do Brasil. Instituto de Geociências, UFRJ, Rio de Janeiro, Tese de Doutorado.

Caldas, E.B.; Lima Filho, F.P.; Florencio, C.P. 1987. Nova ocorrência de metacryphaeus cf. australis (trilobita) no devoniano médio da Bacia do Parnaíba. In: SBP, Congresso Brasileiro de Paleontologia, 10, Rio de Janeiro, Anais, 2:539-444.

Caldas, E.B.; Mussa, D.; Lima Filho, F.P.; Rosler, O. 1989. Nota sobre a ocorrência de uma floresta petrificada de idade permiana em Teresina-Piauí. Boletim. IG-USP, Publicação Especial, 7:69-87.

Calvet, S.E.; Tucker, M.E.; Henton, J.M. 1990. Middle Triassic carbonate ramp systems in the Catalan Basin, northeast Spain: facies, systems tracts, sequences and controls. In: M.E. Tucker; J.L. Wilson; P.D. Crevello; J.R. Sarg; J.F. Read (eds.). Carbonate Platfoms: Facies Sequences and Evolution. Special publication, International Association of Sedimentologists, Blackwell Scientific Publications, Oxford, 9:79-108. 
* Campanha, V.A.; Rocha Campos, A.C. 1979. Alguns microfósseis da Formação Piauí (Neocarbonífero), Bacia do Parnaíba. Boletim Inst. de Geociências, 10:57-67.

Campbell, C.V. 1967. Lamina, laminaset, and bedset. Sedimentology, 8:7-26.

Canuto, J.R. 1997. Estratigrafia de Seqüências do Grupo Bambuí (Proterozóico), nas Serras de Santa Helena e da Água Fria, Estado de Minas Gerais, Brasil, Proposta de um arcabouço cronoestratigráfico de $3^{a}$ ordem. Anais da Academia Brasileira de Cièncias, 69(4):442-447.

Canuto, J.R.; Rocha Campos, A.C.; Santos, P.R. 1997. Arcabouço cronoestratigráfico de $3^{\text {a }}$ ordem para a Formação Rio do Sul, Subgrupo Itararé (Neopaleozóico), Bacia do Paraná, centro-leste de Santa Catarina, Brasil. Anais da Academia Brasileira de Ciências, 69(3):438-439.

* Caputo, M.V. 1984. Stratigraphy, Tectonics, Paleoclimatology and Paleogeography of Northern Basins of Brazil. Universidade da Califórnia, Santa Barbara, USA, Tese de Doutorado, $583 \mathrm{p}$.

Caputo, M.V.; Lima, E. 1984. Estratigrafia, idade e correlação do Grupo Serra Grande da Bacia do Parnaíba. In: SBG, Congresso Brasileiro de Geologia, 33, Rio de Janeiro, 1984, Anais, 2:740-759.

Carozzi, A.V.; Falkenhein, F.V.M.; Carneiro, R.G.; Esteves, R.F.; Confreitas, C.J.A. 1975. Análise ambiental e evoluçấo tectónica sinsedimentar da seção siluro-eocarbonífera da Bacia do Maranhão. Ciência-técnicapetróleo. Seção Exploraçáo de petróleo, 7:1-14.

Carvalho, R.S. 1987b. Sedimentação evaporítica. In: Seminário sobre "refts"intracontinentais. Petrobrás, Rio de Janeiro, 52-57.

Carvalho, R.S.; Simóes, I.A.; Tibana, P.; Leite, D.C. 1974. Evaporitos de Sergipe. Geologia e Geoquímica. Relatório interno, projeto evaporitos, Aracaju, 1:155p.

Castro, J.C. 1995. Ciclos ou Seqüéncias no arcabouço cronoestratigráfico da sucessão Itararé (Formação Taciba)-Rio Bonito (Membro Triunfo). In: Simpósio sobre Cronoestratigrafia da Bacia do Paraná, 2ILEAJUFRGS, Porto Alegre, Resumos Expandidos, 1: 66-70.

Castro, J.C. 1996. Uma reavaliação de antigos deltas marinhos, sob a ótica da Estratigrafia de Sequências. In: Congresso. Brasileiro de Geologia, Salvador, 1996, Anais, 39, 1:221-223.

Chang, K.H. 1975. Unconformity-bounded stratigraphic units. Geological Societ America Bulletim, 86:15441552.

Coimbra, A.M. 1983. Estudo Sedimentológico e Geoquímico do Permo-Triássico da Bacia do Maranhão. Instituto de Geociências, USP, São Paulo, Tese de Doutorado (2 V), $259 \mathrm{p}$.

Cordani, U.G.; Brito Neves, B.B. de; Fuck, R.A.; Porto, R.; Thomas Filho, A.; Cunha, F.M.B. da. 1984. Estudo preliminar da integração do Pré-Cambriano com os eventos tectônicos das bacias sedimentares brasileiras. Ciência-técnica-petróleo. Seção Exploração de petróleo, 15:1-70.

Coutinho, M.G.N.; Ferreira, C.A.; Batista, M.B. 1986. Mapa geológico do Estado do Piauí -Escala 1:1.000.000. DNPM/MME, Divisão de Geologia e Mineralogia.

Coutinho, M.G.N.; Ferreira, C.A.; Batista, M.B. 1995. Mapa geológico do Estado do Piauí - Escala 1:1.000.000. CPRM, Serviço Geológico do Brasil.

Crowell, J.C. 1978. Gondwana glaciation cyclothems, continental positioning and climate change. American Journal of Science, 278:1345-1372.

Cruz, W.B.C.; Lima, E.A.M.; Leite, J.F.; Quino, J.S.; Angelim, L.A.A.; Vale, P.A.B.R. 1973. Projeto carvão da Bacia do Parnaíba. CPRM/DNPM (Ret. final. da $1^{\mathrm{a}}, 2^{\mathrm{a}}$ e $3^{\mathrm{a}}$ etapas).

"Cunha, F.M.B. 1986. Evolução paleozóica da Bacia do parnaíba e seu arcabouço tectónico. Instituto de Geociências, UFRJ, Rio de Janeiro, Tese de Mestrado, $107 \mathrm{p}$.

Daemon, R.F. 1974. Palinomorfos-guias do Devoniano Superior e Carbonífero Inferior das bacias do Amazonas e Parnaiba. Anais da Academia Brasileira de Ciências, 46:549-587.

Daemon, R.F. 1976. Correlação bioestratigráfica entre os sedimentos do Siluriano, Devoniano e carbonífero Inferior das bacias do Amazonas, Parnaíba e Paraná. In: SBG, Congresso Brasileiro de Geologia, 29, Belo Horizonte, Anais, 1:189-194.

De Boer, P.L.; Oost, A.P.; Visser, M.J. 1989. The diurnal inequality of the tide as a parameter for recognizing tidal influence. Journal of Sedimentary Petrology, 59:912-921.

Della Fávera, J.C. 1980. Reconhecimento de novas fácies e ambientes deposicionais na Bacia do Parnaíba. In: SBG, Congresso Brasileiro de Geologia, 31, Camburiú, Anais, 2:357.

Della Fávera, J.C. 1982. Devonia storm-and-tide-dominated shelf deposits, Panaíba Basin, Brasil. American Association Petroleum Geologists Bulletin, 66:562. 
* * $*$ Della Favera, J.C. 1984. Eventos de sedimentação episódica nas bacias brasileiras. Uma contribuição para atestar o caráter pontuado do registro sedimentar. In: SBG, Congresso Brasileiro De Geologia, 33, Rio de Janeiro, Anais, 1:489-501.

Della Fávera, J.C., 1990. Tempestito da Bacia do Parnaiba. Instituto de Geociências, UFRGS, Porto Alegre, Tese de Doutorado (2 v).

Della Fávera, J.C., 1991. Estratigrafia de Sequeências. In: SBG, Simpósio de Geologia do Sudeste, 2, Săo Paulo, (Notas de Curso, inédito), $35 \mathrm{p}$.

Dequech, V., 1950, Trabalho de pesquisa de carvão e água subterrânea no Piauí. Divisão de Fomento da Produção Mineral. D.N.PM. Boletim. n.87, p. 43-59, Rio de Janeiro.

Dequech, V., 1949, Diário do Congresso Nacional, ano 4, $N^{\circ} 63,7-4,2646$.

Dolianiti, E., 1954, A flora do Carbonífero inferior de Terezina, Pl: Divisão de Fomento da Produção Mineral. DNPM, Boletim 148, Rio de Janeiro, $56 \mathrm{p}$

Duarte, A. 1936. Fósseis da sondagem de Teresina-Piauí. Notas Preliminares e estudos. DNPM, 2:1-3.

Dunbar, C.O.; Rogers, J. 1957. Principles of Stratigraphy. New York, John Wiley and Sons, 356 p.

Emery, D. 1998. Historical Perspective. (3nd. Ed) In: D. Emery and K. J. Myers (eds) Sequence Stratigraphy, Special Publication, BP Exploration, Stockley Park Uxbridge, London, Blackwell Science, 3-7.

Emery, D.; Myers, K.J 1998. Sequence Stratigraphy. Special Publication, BP Exploration, Stockley Park Uxbridge, London, Blackwell, 297 p.

Fairbridge, R.W.; Sanders, J.E. 1987. The sun's orbit, A.D. 750-2050: basis for new perspectives on planetary dynamics and the Earth-Moon linkage. In: Rampino et al., (eds) Climate- history, periodicity, predictability., New York, Van Nestrand Reinhold, 446-471.

Faria Jr., L.E. 1984. O Permo-Triássico na Bacia do Parnaíba: um modelo de paleodeserto. In: SBG, Congresso Brasileiro de Geologia, 33, Rio de Janeiro, Anais, 2:777-784.

Faria Jr., L.E.; Truckenbrodt, W. 1980. Estratigrafia e petrografia da Formação Pedra de Fogo - Permiano da Bacia do Maranhão. In: SBG, Congresso Brasileiro de Geologia, 21, Camburiú, Anais, 2:740-754.

Figueiredo, A.M.; Gabaglia, G.P. 1986. Sistema classificatório aplicado às bacias sedimentares brasileiras. Revista Brasileira de Geociências, 16(4):350-369.

Fischer, A.G. 1964. The Lofer cyclothems of the Alpine Triassic. Kansas Geological Survey Bulletin, 169:107149.

Florencio, C.P.; Ribeiro Filho, E.R. (in Press). Geoquímica do bromo em halitas da Sub-Bacia Evaporítica de Maceió. Revista brasileira de Geologia, DEGEO-UFC.

Fortes, F.P., 1996. Geologia de Sete Cidades. Teresina, Fundação Cultural Monsenhor Chaves, 144 p.

Frazier, D.E. 1974. Depositional episodes: their relationship to the Quaternary stratigraphic framework in the northwestern portion of the Gulf Basin. University of Texas, Austin, Bureau of Economic Geology. Geol. Circ. 4(1):1-28.

Galloway, W.E. 1989. Genetic stratigraphic sequence in basin analysis: architecture and genesis of flooding suface bounded depositional units. American Association of Petroleum Geologist Bulletim, 73:125-142.

Goes, A.M. 1995. A Formação Poti (Carbonifero Inferior) da Bacia do Parnaiba. Instituto de Geociências, USP, São Paulo, Tese de Doutorado, $171 \mathrm{p}$.

Goes, A.M.O.; Feijó, F. 1994. Bacia do Parnaiba. Boletim de Geociências da Petrobrás, 8(1):57-67.

Goes, A.M.O.; Souza, J.M.P.; Teixeira, L.B. 1990. Estágio Exploratório e Perspectivas Petroliferas da Bacia do Parnaíba. Boletim de Geociências da Petrobrás, 4:55-63.

Goldhamer, R.K.; Dunn, P.A.; Hardie, L.A. 1990. Depositional cycles, composite sea level changes, cycle stacking patterns, and the hierarchy of statigraphic forcing: exemples from platform carbonates of the Alpine Triassic. Geological Society of America Bulletin, 102:535-562.

Greb, S.; Archer, A.W. 1995. Rhythmic sedimentation in mixed tide and wave deposit, Hazel Patch Sandstone (Pennsylvanian), eastern kentucky coal field. Journal of Sedimentary Research, 65:96-106.

Havholm, K; Kocureck, G. 1991. Control on aeolian facies architecture, Middle Jurassic Page Sandstone, Colorado Plateau. AAPG Bulletim, 75:591.

Heckel, P.H. 1983. Diagenic model for carbonate rocks in Midcontinent Pennsylvanian eustatic cyclothems. Journal of Sedimentary Petrology, v. 3, 53:733-759.

Hite, R. 1970. Shelf carbonate sedimentation controlled by salinit in the Paradox Basin, southeast Utha. In: Symposium on salt, 3, Northern Ohio Geological Society, 1:48-66. 
lanuzzi, R. 1994. Reavaliação da Flora Carbonifera da Formação Poti, Bacia do Parnaíba. Instituto de Geociências, USP, São Paulo, Dissertação de Mestrado, 233 p.

James, N.P.; Kendall, A.C. 1992. Introduction to carbonate and evaporite facies models. In: Walker, N.P.; James, N.P. (eds.). Facies Models: response to sea level change. Geological Association of Canada, St John's, Newfoundland, 265-275.

Kegel, W. 1951. Sobre alguns trilobitas carboníferos do Piauí e do Amazonas. Boletim. Divisão de Geologia $e$ Mineralogia, 153:1-38.

Kegel, W. 1953. Contribuição ao Estudo do Devoniano da Bacia do Parnaiba. Boletim. Divisão de Geologia e Mineralogia, 141:1-48.

Kegel, W. 1956. As inconformidade na Bacia do Parnaiba e zonas adjacentes. Boletim. Divisão de Geologia e Mineralogia, 160:1-60.

Kegel, W.; Costa, M.T. da. 1951. Espécies Neopaleozóicas do Brasil, da família Aviculopectinidae, ornamentadas com costelas fasciculadas. Boletim. Divisão de Geologia e Mineralogia, 137:1-48.

Kendal, A.C. 1992. Evaporites. In: Walker, R.G.; James, N.P. (eds.). Facies Models: Response to Sea level change. Geological Association of Canada, Ontario, 375-409.

Kirkland, D.; Evans, R. 1981. Source rock potential of evaporitic envirounmoments, AAPG Bulletin. 65:181-190.

Klein, G. de V.; Willard, D.A. 1989. Origin of Pennsylvanian coal-bering cyclothems of North America. Geology, 17:152-155.

Krumbein, W.C.; Sloss, L.L. 1963. Stratigraphy and sedimentation. 2d. ed. San Francisco.

Kuercher, G.M.; Wooldland, B.G.; Broadhust, F.M. 1990. Evidence of deposition from individual tides and tidal cycles from the Francis Creek Shale (host rock the Manzon Creek biota), Westphalian D (Pennsylvanian), northeastern Illinos. Sedimentary Geology, 68:211-221.

Kvale, E.P.; Archer, A.W. 1990. Tidal deposits associated with low-sulfur coals, Brazil Fm. (Lower Pennsylvanian), Indiana. Journal of Sedimentary Petrology, 60:563-574.

Kvale, E.P.; Archer, A.W. 1991. Characteristics of two Pennsylvanian-age, semidiurnal tidal deposits in lllinois Basin, U.S.A. In: D.G. Smith, B.A. Zaitlin and R.A. Rahmani, (Eds) Clastic Tidal Sedimentology. Canadian Society of Petroleum Geologist Memoir, 16:179-188.

Lanzarini, W.L. 1984. Fácies sedimentares e ambientes deposicionais da Formação Monte Alegre na área de Jurua, Bacia do Alto Amazonas, Brasil. Departamento de Geologia da escola de minas de UFAP, Dissertação de mestrado.

Legarreta, L.; Uliana, M.A.; Larotonda, C.A.; Meconi, G.R. 1993. Appraches to nomarine sequence stratigraphytheorical models and examples from Argentine basins. In: Institut Français du Petrole, Conference on Exploration and Production: Subsurface Reservoir Characterization from Surface Observations, Scarborough, England. Publ. IFT, Technip.

Leite, J.F.; Aboarrage, A.M.; Daemon, R.F. 1975. Projeto carvão da Bacia do Parnaiba -Relatório final das etapas II elll. Recife, DNPM/CPRM. 5v.

Lima Filho, F.P. 1991a. Fácies e ambientes deposicionais da Formação Piaúl (Pensilvaniano), Bacia do Parnaíba. Instituto de Geociências, USP, São Paulo, Dissertação de Mestrado, 137 p.

*ima Filho, F.P. 1991b. Fácies carbonáticas da Formaçăo Piaú (Carbonífero, Bacia do Parnaíba). In: Cong. Bras. Paleont. Soc. Bras. Paleontologia, 12, São Paulo, Resumos: 44.

Lima Filho, F.P.; Anelli, L.E. 1997. Contribution to the Late Paleozoic stratigraphy of the Parnaiba basin. Newsletter on Carboniferous Stratigraphy. IUGS Subcommission on Carboniferous Stratigraphy. 15:36-37.

Lima Filho, F.P.; Caldas, E.B. 1988. Ocorrência de uma floresta petrificada no Permiano da Bacia do Parnaíba. Teresina, Carta Cepro, 13(1):5-14.

Lima Filho, F.P.; Machado, M.F.; Córdoba, V.C.; Souza, D.C. 1995, O Permo-Pensilvaniano na porção nordeste da Bacia do Parnaiba: exemplo de sedimentação costeira. In: Simpósio de Geologia do Nordeste, 16, Recife, Anais, 1:370-373.

Lima Filho, F.P.; Rocha-Campos, A.C. 1992. Sedimentos desérticos da Formação Piaul (Pensilvaniano), Bacia do Parnaíba. Boletim do Instituto de Geociencias, Universidade de São Paulo, Publ. Especial, 12:67-68.

Lima Filho, F.P.; Rocha-Campos, A.C. 1993. Formação Piauí: um modelo de ambiente desértico e evaporítico. Academia Brasileira de Ciências, Resumos, 65(3):324-325.

Lima, E. A.M.; Leite, J.F. 1978. Projetos Estudo Global dos Recursos Minerais da Bacia Sedimentar do Araripe. Integração Geológica Metalogenética. Recife, DNPM-CPRM, $16 \mathrm{v}$. 
Lindsay, J.F.; Kenard, J.M.; Southgate, P.N. 1993. Aplication of sequence stratigraphy in na intracratonic setting, Amadeus Basin, central Austrália. In: H. W. Posamentier, C. P. Summerhayes, B. U. Hall and G. P. Allen (eds.) Sequence Stratigraphy and facies associations. Oxford, Blackwell, 605-630.

Longman, M.W.; Fertal, T.G.; Glennie, J. 1983. American Association of petroleum Geologist, 67:744-771.

Loutit, T.S.; Handenbol, J.; Vail, P.R.; Baum, G.R. 1988. Condensed sections: the key to age determination and correlation of continental margem sequence, In: C.K. Wilgus, B.S. Hastings, C. G. St Kendal, H.W. Posamentier, C.A. Ross and J.C. Van Wagoner (Eds.) Sea Level Changes: an Integrated Approach Special Publication, Society of Economic Paleontologists and Mineralogist, Tulsa, 42:183-213.

Lucia, F.J. 1972. Recognition of evaporite-carbonate shoreline sediments . In: Rigy, J.K.; Hamblin, W.K. (eds), recognition of ancient sedimentary environments. Soc. Econ. Paleont. Mineral. Spec. Publ., 43:259-274.

Mabesoone, J.M. 1977. Paleozoic-Mesozoic Deposits of the Piauí-Maranhão syneclise (Brazil): geological history of a sedimentary basin. Sedimentary Geology, 19:7-38.

Mabesoone, J.M. 1978. Origem dos conglomerados da Formação Serra Grande e unidades equivalentes (Siluriano Superior-Devoniano Inferior), Nordeste do Brasil. In: SBG, Congresso Brasileiro de Geologia, 30 , Recife, Anais, 2:779-808.

Martino, R.L.; Sanderson, D.D. 1993. Fourier and autocorrelation analysis of estuarine tidal rhythmites, lower Breathitt Formation (Pennsylvanian), eastern Kentucky, USA. Journal of Sedimentary Petrology, 26:105-119.

Mesner, J.C.; Wooldridge, L.C.P. 1964. Maranhäo Paleozoic Basins and Cretaceus Costal Basins, North Brazil. Bulletim of the American Association of Petroleun Geologists, 48(9):1475-1512.

Miall, A. D. 1991. Stratigraphy sequence and their chronostratigraphic correlation. Journal of Sedimentary Petrology, 61:497-505.

Miall, A. D. 1992. The Exxon global cycle chart: an event for every occasion? Geology, 20:787-790.

Miall, A. D. 1994. Sequence stratigraphy and chonostratigraphy, problems of definition and precision in correlation, and its implications for global eustasy. Geocience Canada, 21:1-26.

Miall, A. D. 1995. Whither stratigraphy? Sedimentary Geology, 100:5-20.

Mitchum, R.M. 1977. Seismic stratigraphy and global changes of sea level, Part 1: Glossary of terms used in seismic stratigraphy. Seismic Stratigraphy - Applications to hydrocarbon exploration In: C.E. Payton (ed.) Memoir of the American Association of Petroleum Geologists, Tulsa, 26:205-212.

Mitchum, R.M.; Vail, P.R.; Sangree, J.B. 1977b. Seismic stratigraphy and global changes of seamevel. Part 6 : Seismic stratigraphy - Application to Hydrocarbon Exploration. In: C.E. Payton (ed.) Memoir of the American Association of Petroleum Geologists, Tulsa, 26:117-134.

Mitchum, R.M.; Vail, P.R.; Thompson, S. 1977a. Seismic stratigraphy and global changes of sea-level. Part 2: the depositional sequence as a basic unit for stratigraphic analysis. Seismic Stratigraphy - Applications to Hydrocarbon Exploration. In: C.E. Payton (ed.) Memoir of the American Association of Petroleum Geologists, Tulsa, 26:53-62.

Moore, R.C. 1931. Pennsylvanian cycles in the northen Midcontinent region. Illinois Geological Survey Bulletin, 60:242-257.

Muller, H. 1962. Report on palynological results of samples examined from wells in Maranhão. Petrobrás, região de produçäo da Bahia, Salvador, Brasil. Relatório interno $N^{\circ} 500$. Sistema de informação em exploração SIEX, $72 \mathrm{p}$.

Myers, K.J.; Milton, N.J. 1998. Concepts and principles. (3nd). In: D. Emery and K. J. Myers (ed.) Sequence Stratigraphy Special Publication, BP Exploration, Blackwell Association of Publication, Stockley Park Uxbridge, London, 11-41.

Myrow, P.M. 1992a. Bypass-zone tempestite facies model and proximaly trends for na ancient muddy shoreline and shelf. Journal of Sedimentary Petrology, 62:99-115.

Myrow, P.M. 1992b. Pot and gutter cast from the Chapel Island Formation, Southeast Newfoudland. Journal of Sedimentary Petrology, 6:992-1007.

Oliveira, A.I.; Leonardos, O.H. 1943. Geologia do Brasil. 2 ed. Serv. Inf. Agric.(Série Didática), Rio de Janeiro, $472 p$.

Payton, C.E. (Editor), 1977, Seismic stratigraphy - aplications to hydrocarbon exploration. Memoir of the American Association of Petroleum Geologists, Tulsa, 26:516p.

Perlmutter, M. A.; Matthews, M.D. 1989. Global cyclostratigraphy - a model. In: Cross, T. A. (ed.). Quantitative Dynamic Stratigraphy. London, Prentice Hall, 233-260. 
Peterson, J.A $A_{1}$ Hite, R.J. 1969. Pennsylvanian evaporite-carbonate cycles and their relationship to petroleum occurence. Bull. Amer. Assoc. Petroleum Geologist, 53:884-908.

Plummer, F.B.; Price, L.I.; Gomes, F. A. 1948. Estados do Maranhão e Piauí (Geologia): Brasil. Rio de Janeiro, Conselho Nacional do Petróleo, 87-134 (Relatório 1946).

Posamentier, H. W.; Allen, G.P. 1993. Siliciclastic sequence stratigraphic patterns in foreland ramp-type basins. Geology, 21:455-458.

Posamentier, H. W.; Vail, P.R. 1988. Eustatic control on clastic deposition II. In: Sea Level Changes: an Integrated Approach. Wilgus C.KHastings.; B.S.; Kendal C. G. St; Posamentier H.W.; Ross C.A. Van Wagoner J.C (eds.). Society of Economic Paleontologists and Mineralogist, Special Publication, Tulsa, 42:125-154

Posamentier, H.W.; James, D.P. 1993. Na overview of sequence stratigraphi concepts: uses e abuses. In: Sequence Stratigraphy and facies associations. Posamentier H.W.; Summerhayes, C.P.; Haq B.U. Allen G.P. (eds.). Special publications, Internatiional Association of Sedimentologists, Oxford, Blackwell Association of Publication, 18:3-18.

Posamentier, H.W.; Jervey, M.T.; Vail, P.R.1988. Eustatic control on clastic deposition I- Conceptual Framework. In: Wilgus, C.K.; Hastings, B.S. Kendal, C. G. St. Posamentier, H.W.; Ross, C.A.; Van Wagoner J.C. (eds.). Sea Level Changes: an Integrated Approach. Special Publication, Society of Economic Paleontologists and Mineralogist, Tulsa, 42:109-124.

Quadros, L.P. 1982. Distribuição bioestratigráfica dos Chitinozoários e Acritarcas na Bacia do Parnaíba. Ciência-Técnica-Petróleo, Seção de Exploração, 12:1-76.

Ramsbottom, W.H.C. 1979. Rates of transgression and regression in the Carboniferous of NW Europe. Geological Society, London, 136:147-153.

Read, J.F. 1989. Controls on evolution of Cambriam - Ordovician passive margin, U.S. Appalachians. In: Crevello, P.D.; Wilson, J.L.; Sarg, J.F. (ed.). Controls on Carbonate Platform and Basin Development. Tulsa, Society Economic Paleontologists and Mineralogists. 125154. (SEPM. Special Publication, 44).

Read, J.F.; Goldhammer, R.K. 1988. Use of Fischer plots to define Third-order sea-level curves in Ordovician Peritidal cyclic Carbonates, Appalachians. Geology, 16:895-899.

Reading, H.G. 1978. In: Reading, H.G.(eds.). Sedimentary Environments and Facies. Blackwell Scientific Publications. London, 569 .

Resende, W.M.; Pamplona, H.R.P. 1970. Estudo do desenvolvimento do Arco Ferrer-Urbano Santos. Boletim técnico da Petrobrás, vol. 13:5-14.

Ribeiro, J.A.P.; Melo, F.; 1996, Os sistemas deposicionais da Bacia do Parnaíba a norte de Teresina, Piaui. Revista de Geologia, 9:53-73.

Rocha Campos, A.C.; Santos, P.R.; Canuto, J.R. 1994. Ice Scouring in Late Paleozoic rhytmites, Paraná Basin, Brasil. In: Deynoux, M; Domack E.W.; Eyes, N.; Fairchild, I.J.; Young, G.M. (eds.), The Earth's Glacial Record, Cambridge University Press, 234-240.

Rodrigues, R. 1967. Estudo sedimentológico e estratigráfico dos depósitos silurianos e devonianos da Bacia do Parnaíba.. Belém, Petrobrás, Relatório interno 49p.

Sadler, P.M.; Osleger, D.A.; Montañez, I.P. 1993. On The labeling, lenght, and objective basis of the Fischer plots. Journal of SedimentarY petrology, Tulsa, Vol. 63, 3:360-368.

Santos, P.R.; Rocha Campos, A.C.; Canuto, J.R.1992. Estruturas de arrasto de icelbergs em ritmito do Subgrupo Itararé (Neopaleozóico), Trombuto Central, SC. Boletim do Igec- Série Científica, 23:1-18.

Sarg, J.F. 1988. Carbonate sequence stratigraphy. In: Wilgus, C.K.; Hasting, B.S.; Kendall, C.G.St.C.; Posamentier, H.W.; Ross, C.A.; Van Wagoner, J.C. (eds.). Sea level Changes - an integrated aproach. Soc. Econ. Paleontol. Mineral, Special public., 42155-181.

Scholz, C.A.; Johnson, T.C.; Mcgill, W.J. 1993. Deltaic sedimentation in a rift valley lake: new seismic reflection data from Lake Malawi (Nyasa), east Africa: Geology, 21:395-398.

Scholz, C.A.; Rosendahl, B.R. 1988. Low lake stands in lakes Malawi and Tanganyika, east Africa, delineated with multifold seismic data. Science, 240:1645-1648.

Segal, M.P.; Kuehl, S.A. 1994 Sedimentary structures on the Bengal Shelf: a multi-scale approch to sedimentary fabric interpretation. Sedimentary. Geology, 93:165-180.

Shanley, K.W.; McCabe, P.J. 1994. Perpectives on the sequence stratigraphy of continental strata. AAPG Bulletim, 78:544-568. 
Silva, O.B. 1996. Ciclicidade sedimentar no Pensilvaniano da Bacia do Amazonas e o controle dos ciclos de sedimentação na distribuição estratigráfica dos Conodontes, Fusulinídeos e Palinomorfos. Instituto de Geociências, UFRGS, Porto Alegre, Tese de doutorado, $331 \mathrm{p}$.

Sloss, L.L.; Krumbein, W.C.; Dapples, E.C. 1949 Integrated facies analysis. In: Longwell, C.R. (Ed), Sedimentary Facies in Geologic History. Geol. Soc. Am. Mem., 39:91-124.

Sloss, L.L.1963. Sequences in cratonic interior of North America. Geol. Soc. Am. Bull, 74:93-113.

Small, H. 1914. Geologia e suprimento de água subterrânea no Piauhy e parte do Ceará. Boletim da Inspetoria de Obras contra as Secas. Ser. I.D., 25:1-80.

Suguio, K; Fulfaro, V.J. 1977. Geologia da margem ocidental da Bacia do Parnaíba (Estado do Pará). Boletim IG-USP, 8:31-54.

Swift, D.J.P.; Hudelson, P.M.; Brenner, R.L.; Thompson, P. 1987. Shelf construction in a foreland basin: storm beds, shelf sandbodies, and shelf-slope depositional sequences in the Upper Cretaceous Mesaverde Group, Book Cliffs, Utah. Sedimentology, 34:423-457.

Teixeira, G. De P.; Miranda, J. 1937. Carvão Mineral do Piauí. Boletim. Divisão de Fomento da Produção Mineral, 20-92.

Tucker, M.E.; Wright, V.P. 1990. Carbonate sedimentology. Blackwell Scientific Publications, Oxford, 482p.

Vail, P.R.; Audemard, F.; Bowman, S. A.; Eisner, P. N.; Perez Cruz, C. 1991. The Stratigraphic Signatures of Tectonics, Eustacy and Sedimentology - an Overview. In: Einsele, G.; Ricken, W.; Seilacher, A. (eds.). Events in Stratigraphy. Berlim, Springer-Verlag, 617-659.

Vail, P.R.; Mitchum, R.M.; Thompson, S. 1977. Global cycle of relative changes of sea level. In: C.E. Payton, (ed.). Seismic stratigraphy; aplications to hydrocarbon exploration. Tulsa, American Association of Petroleum Geologist. 26:83-97.

Van Straaten, L.M.J.U. 1950. Giant ripples in tidal channels Tijdschr. Kon. Ned. Aardr. Genootsch, 67:336-341.

Van Wagoner, J.C.; Mitchum, R.M. Jr.; Campion, K.M.; Rahmanian, V.D. 1990. Siliciclastic sequence stratigraphy in well logs, cores and outcrop: Concepts for high resolution correlation of time and facies. American Association of Petroleum Geologist Methods in Exploration Series, Tulsa, 7:55 p.

Van Wagoner, J.C.; Posamentier, H.W.; Mitchum, R.M.; Vail, P.R.; Sarg, J.F.; Loutit, T.S.; Hardenbol, J. 1988. An overview of the fundamentals of sequence stratigraphy and key definitions. In: Wilgus, C.K.; Hastings, B.S.; Kendal, C. G. St ; Posamentier, H.W.; Ross C.A.; Van Wagoner J.C. (eds) Sea Level Changes: an Integrated Approach (Special Publication, Society of Economic Paleontologists and Mineralogist, Tulsa, 42:39-45.

Visser, M.J. 1980. Neap-spring cycles refleted in Holocene subtidal large-scale bedform deposits, a preliminary note, Geology, 8:543-546.

Walker, R.G. 1984. Shelf and shallow marine sands. In: Walker, R.G. (ed.) Facies Models. Geocience, Canada, Reprint Series 1, 141-170.

Wheeler,H.E. 1958. Time-stratigraphy. American Association of Petroleum Geologist, 42:1047-1063.

Wheeler,H.E. 1959. Stratigraphic units in time and space. American. Journal. Science, 257:692-706.

Wilgus, C.K.; Hastings, B.S.; Kendal, C.G. St. C.; Posamentier, H.W.; Ross, C.A.; Van Wagoner, J.C. (eds). 1988. Sea-level Changes: an Integrated Approach (Special Publication, Society of Economic Paleontologists and Mineralogist, Tulsa, 407p.

Wright V.P.; Marriott, S.B. 1993. The sequence stratigraphy of fluvial depositional systems: the role of floodplain sediment storage. Sediemntary geology. 86:203-210.

Yang, C.; Nio, S. 1985. The estimation of palaeohydrodynamic process from subtidal deposits using time series analisis methods. Sedimentology, 32:41-57.

Zhang, Z; Sun, K.; Yin, J. 1997. Sedimentology and sequence stratigraphy of the Shanxi Formation(Lower Permian) in the northwestern Ordos Basin, China: an alternative sequence model for fluvial strata China. Sedimentary Geology., 122:123-136. 